\title{
The ammonoids from the Argiles de Timimoun of Timimoun (Early and Middle Viséan; Gourara, Algeria)
}

\author{
Jürgen Bockwinkel ${ }^{1}$, Dieter Korn ${ }^{*, 2}$ and Volker Ebbighausen ${ }^{3}$ \\ ${ }^{1}$ Dechant-Feinstraße 22, 51375 Leverkusen, Germany. E-mail: jbockwinkel@t-online.de \\ ${ }^{2}$ Museum für Naturkunde Berlin, Invalidenstraße 43, 10115 Berlin, Germany. E-mail: dieter.korn@mfn-berlin.de \\ ${ }^{3}$ Engstenberger Höhe 12, 51519 Odenthal, Germany. E-mail: Volker@vxr.de
}

\begin{abstract}
Received 9 July 2009

Accepted 18 September 2009

Published 19 February 2010

\section{Key Words}

Ammonoidea

Mississippian

Carboniferous

North Africa

taxonomy

Twenty-seven ammonoid species are described from the Argiles de Timimoun of Timimoun (Gourara, Algeria). The following taxa are newly described: Rhnetites n. gen., Rhnetites rhnetensis n. sp., Rhnetites ouladallalensis n. sp., Parahammatocyclus mutaris n. sp., Bollandoceras nitens n. sp., Bollandoceras subangulare n. sp., Bollandoceras politum n. sp., Bollandoceras aridum n. sp., Bollandoceras zuhara n. sp., Bollandoceras mirrih n. sp., Benimehlalites n. gen., Benimehlalites benimehlalensis n. sp., Benimehlalites belkassemensis n. sp., Benimehlalites brinkmanni n. sp., Pachybollandoceras n. gen., Pachybollandoceras intraevolutum n. sp., Pachybollandoceras repens n. sp., Bollanditinae n. subfam., Gourarites n. gen., Gourarites hagaraswad n. sp., Gourarites hagarkarim n. sp., Gourarites mustari n. sp., Gourarites zuhal n. sp., Semibollandites n. gen., Semibollandites kamil n. sp., Semibollandites pauculus n. sp., Semibollandites qawiy n. sp., Timimounia n. gen., Timimounia timimounensis n. sp., Timimounia lunula n. sp., Daaitidae n. fam., Daaites n. gen., Daaites daaensis n. sp., Dimorphoceras lanceolobatum n. sp., Nomismoceras salim n. sp., and Nomismoceras waltoni n. sp. The species occur in three successive horizons and can be attributed to the Bollandites-Bollandoceras Genus Zone (Early and Middle Viséan). They represent the most diverse ammonoid fauna known from this time interval.
\end{abstract}

\section{Introduction}

The Early and Middle Viséan is a time interval within the late Palaeozoic from which the ammonoid record is poorly known. Well-described ammonoid faunas of this time have been recorded from only a few places worldwide, and most of these assemblages show a low faunal diversity (AMMON database; Korn \& Ilg 2009). Therefore, each new record is valuable and contributes significantly to our knowledge of the evolutionary history of the ammonoids within the Early Carboniferous.

Riley (1990) coined the term Bollandites-Bollandoceras Genus Zone for the interval between the last occurrence of the genus Ammonellipsites and the first occurrence of Goniatites. This concept was accepted by Korn et al. (2007), who used this biostratigraphic unit for the North African succession of ammonoids. The
Bollandites-Bollandoceras Genus Zone, however, is a unit that so far has been poorly defined, being characterised by the lack of distinctive genera rather than the occurrence of characteristic faunas. The two name-giving genera are not restricted to this zone; they are still very common in early Asbian assemblages (for a revision of the B2 zone in the North of England, see Korn \& Tilsley 2006). In the following monograph, some new forms will be described and may help to fill some gaps in the diversity of the Palaeozoic ammonoids.

So far the richest faunas from the time interval under discussion are known from the North of England. Riley (1996) described Early and Middle Viséan (late Chadian to Holkerian in the British chronostratigraphic scheme) ammonoids from the Craven Basin in Lancashire; they came from several successive horizons (in ascending order):

\footnotetext{
* Corresponding author
} 
Hodder Mudstone Formation, Leagram Mudstone Member (lower portion) (late Chadian):

Ammonellipsites clitheroensis

Helicocyclus divergens

Rotopericyclus postremus

Eonomismoceras planum

Beyrichoceratoides inflatus

Dzhaprakoceras deflexum

Dzhaprakoceras bellmanense

Dzhaprakoceras catena

Dzhaprakoceras flexum

Dzhaprakoceras hispanicum

Dzhaprakoceras subglobosum

Dzhaprakoceras levis

Dzhaprakoceras paracatena

Dzhaprakoceras westheadi

Dzhaprakoceras undulatum

Merocanites quadrilobus

Michiganites sp.
= Ammonellipsites clitheroensis

= Helicocyclus divergens

= Rotopericyclus postremus

= Eonomismoceras planum

= Dzhaprakoceras inflatum

= Dzhaprakoceras deflexum

= Bollandoceras bellmanense

= Dzhaprakoceras catena

= Dzhaprakoceras flexum

= Dzhaprakoceras cf. hispanicum

= Dzhaprakoceras cf. subglobosum

= Dzhaprakoceras levis

= Dzhaprakoceras paracatena

$=$ Bollandoceras westheadi

= Bollandoceras undulatum

= Merocanites quadrilobus

$=$ Michiganites sp.

A similar but less diverse assemblage was recorded from the Peak district (Tilsley \& Korn 2009)

Hodder Mudstone Formation, Chaigley Limestone Member (Arundian):

Parahammatocyclus chaigleyensis

Dzhaprakoceras hispanicum

= Parahammatocyclus chaigleyensis

= Dzhaprakoceras cf. hispanicum
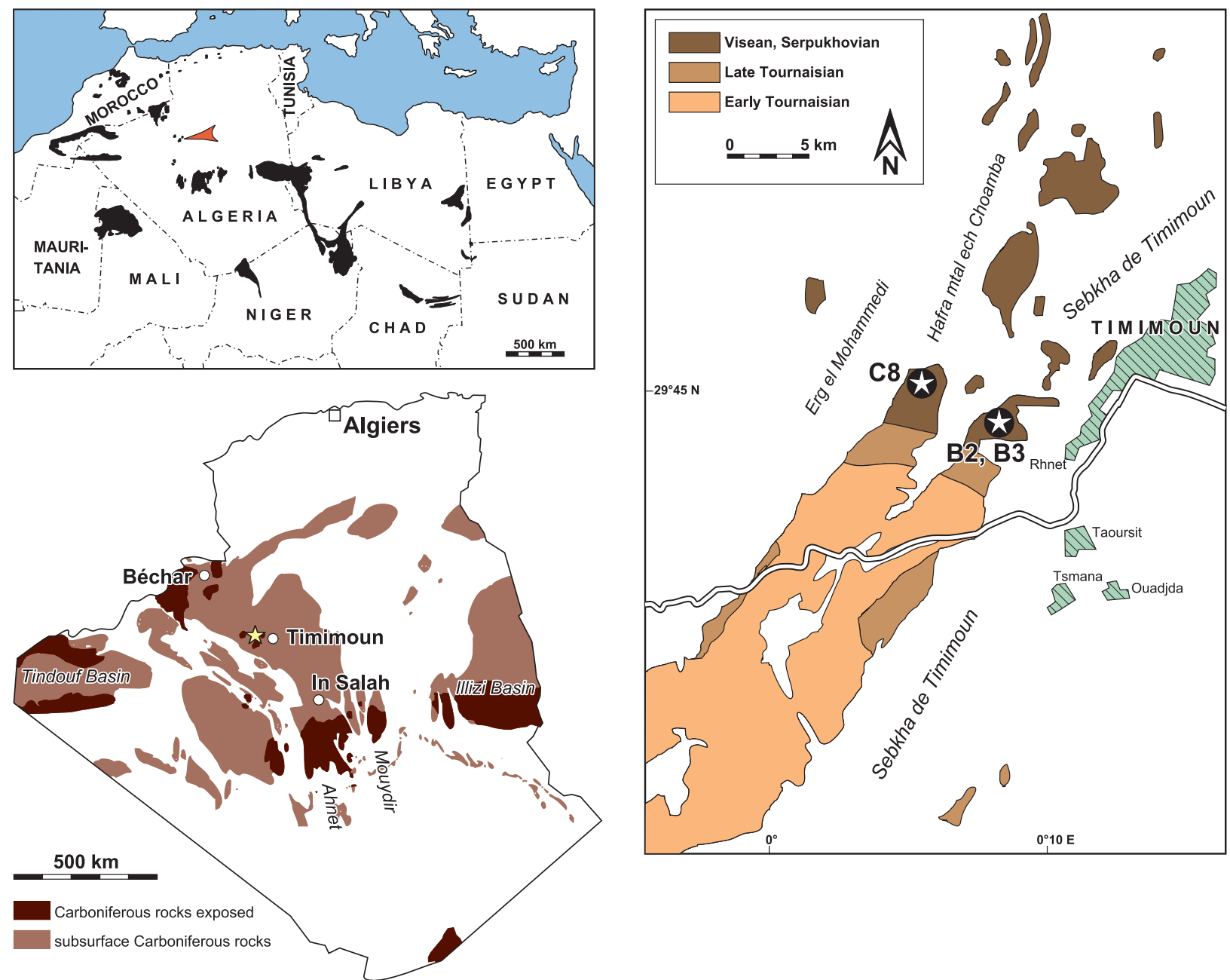

Figure 1. The outcrop of Palaeozoic rocks in northern Africa and Iberia and the geographic position (marked by an asterisk) of the fossil localities in the Grès de Kahla supérieur near Timimoun. 
Beyrichoceratoides sp. 2

Bollandoceras sp. 1

Bollandoceras sp. 2

Bollandites? sp.
= Bollandoceras sp.

$=$ Bollandoceras $\mathrm{sp}$.

= Bollandoceras sp.

$=$ Bollandites ? sp.

Hodderense Limestone Formation (Holkerian):
Bollandites varians
$=$ Bollandites varians
Bollandoceras hodderense
= Bollandoceras hodderense
Nomismoceras rotiforme
= Nomismoceras sp.
Dimorphoceras leagramense
= Dimorphoceras leagramense
Merocanites cf. applanatus
= Merocanites cf. applanatus

Additional faunas, but with less precise stratigraphic affiliation, were reported from various other places:

North Urals (Kusina 1973, 1980; Shimansky \& Kusina 1977) - some localities near the Komi River yielded species of the genera Bollandoceras (?), Bollandites (?), Hammatocyclus, Rhiphaeocyclus, Helicocyclus, and Dzhaprakoceras. These may have a late Chadian age.

Northern Ireland (Padget 1952) - Bollandoceras furiense was recorded from the Fury River.

Wales (George \& Ponsford 1935) - The possible record of the genera Eurites, Intoceras, Kozhimites, Bollandites, and Merocanites near Gower may indicate a late Chadian age.

Ukraine - Findings at the Mokraya Volnovakha River (Kusina 1991) included Bollandites donetsensis, Bollandites mediocris, Bollandoceras stylense, and Dimorphoceras sp.; they may be a time equivalent of the assemblages from Timimoun.

Yunnan - Liang \& Zhu (1988) and Wang et al. (1998) described various ammonoid species from the Baoshan Block. It is probably a mixed fauna from late Chadian to Late Viséan age. The presence of the genera Bollandoceras, Bollandites, and Michiganites may indicate that parts of the fauna have an Early or Middle Viséan age.

New South Wales - an ammonoid described as Beyrichoceras trevallynense by Brown et al. (1964) and Roberts (1965) from Trevallyn may belong to Bollandites.

Tien Shan of Kyrgyzstan (Librovitch 1927; Popov 1965, 1968, 1975) - The highest of the seven stratigraphic units yielded Bollandoceras librovitchi and B. tianshanicum; they may have an Early or Middle Viséan age.

Early and Middle Viséan ammonoids from North Africa have been listed and figured several times, but an extensive monographic description does not exist. Ammonoids of this age were reported from the following regions:

Figure 2. Stratigraphic section of the Early Carboniferous (Mississippian) rock succession near Timimoun with the position of the assemblages from the Argiles de Timimoun.
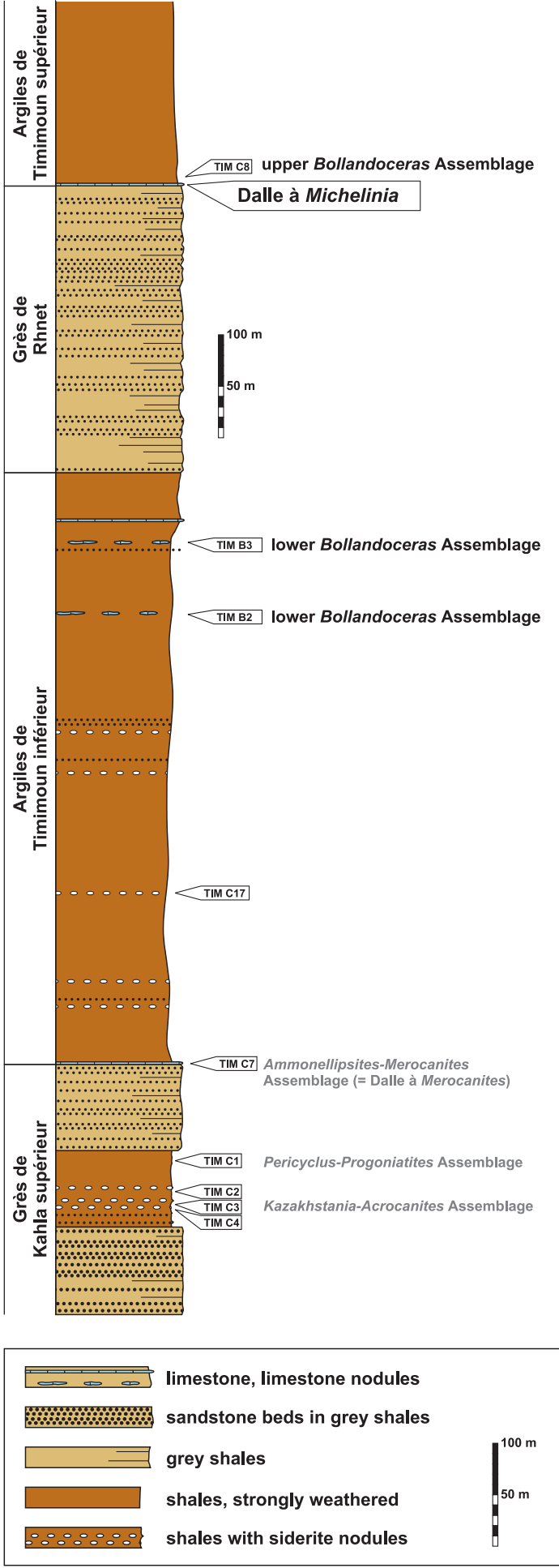
Saoura Valley of north-western Algeria (Pareyn 1961) Rather poor ammonoid assemblages are known from several horizons, in ascending order:

Horizon S2a (Djorf el Morhabar Sud) - with Eurites, Dzhaprakoceras, and Michiganites; it is possibly a late Chadian fauna.

Horizon S2b (Djebel Ioucha) - with Muensteroceras, Dzhaprakoceras, and Michiganites; it is possibly also a late Chadian fauna.

Horizon S2b (Banc de Mazzer) - Merocanites ogivalis is not particularly indicative.

Ahnet of south Algeria - Conrad (1984) illustrated some specimens belonging to the genera Bollandoceras and Bollandites.

Gourara of western Algeria - Conrad (1984) figured specimens, which belong to the genera Bollandoceras and Bollandites, in limonitic preservation from the Argiles de Timimoun supérieur. We re-investigated this horizon; it was the most prolific fossil horizon for Early and Middle Viséan ammonoids of the area west of Timimoun. Furthermore, two additional faunal beds with calcareous ammonoids were discovered below this horizon.

Western Libya (Massa et al. 1974) - Bollandoceras cf. hodderense may indicate a Middle Viséan age.

It was particularly the third occurrence, $13 \mathrm{~km}$ westsouthwest of Timimoun, which turned out to be very productive for ammonoid faunas; it yielded a large suite of material during the field trips by the present authors. This fauna will be described here for the first time to complement the monographs of the early Late Tournaisian (Korn et al. 2010a, 2010b) and latest Tournaisian/ earliest Viséan (Ebbighausen et al. 2010; Korn et al. 2010c) assemblages from the Central Sahara of Algeria.

\section{Geological setting and stratigraphy}

The ammonoid faunas described here come from three localities (TIM-B2, TIM-B3, TIM-C8) $10 \mathrm{~km}$ westsouthwest, $9.5 \mathrm{~km}$ west-southwest, and $13.3 \mathrm{~km}$ west of Timimoun (Gourara, western Algeria), at the south-western margin of the Grand Erg Occidental (Figs 1, 2). Carboniferous sedimentary rocks are exposed between the sand dunes of the Grand Erg, extending over a distance of approximately $40 \mathrm{~km}$ in a SW-NE erosion window that ranges in width between a few hundred metres and $10 \mathrm{~km}$. The rocks are gently inclined towards the north-east (usually $20^{\circ}$ to $35^{\circ}$ ). Their succession (Conrad 1984) consists mainly of shales with several intercalated sandstone formations; carbonates are very rare and restricted to distinct horizons.

The material described in this monograph comes from three horizons, of which two samples (localities B2 and B3) have a position in the upper portion of the Argiles de Timimoun inférieur, 140 and $65 \mathrm{~m}$ below the base of the Grès du Rhnet, and one sample (locality C8) is located at the base of the Argiles de Timimoun supérieur, immediately above the Dalle à Michelinia (a $2.70 \mathrm{~m}$ thick unit of nodular limestone containing numerous colonies of the tabulate coral Michelinia).

All three samples show the genus Bollandoceras to be the dominant ammonoid genus. This alone is not a criterion for a precise stratigraphic attribution of the assemblages, but the co-occurrence with the genus Para-

\begin{tabular}{|c|c|c|c|}
\hline & chronostrat. & ammonoid genus zones & possible position of ammonoid assemblages \\
\hline \multirow{11}{*}{ 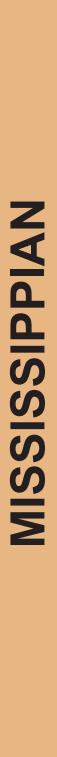 } & \multirow{2}{*}{ SERPUKHOVIAN } & Eumorphoceras - Cravenoceratoides & \multirow{11}{*}{$\begin{array}{l}\star \text { Goniatites gerberi Assemblage } \\
\star \text { Goniatites rodioni Assemblage } \\
\star \text { Goniatites tympanus Assemblage } \\
\star \text { Entogonites-Maxigoniatites Assemblage } \\
\star \text { upper Bollandoceras Assemblage } \\
\star \text { lower Bollandoceras Assemblage } \\
\star \text { Ammonellipsites-Merocanites Assemblage }\end{array}$} \\
\hline & & Tumulites - Cravenoceras & \\
\hline & \multirow{5}{*}{ VISÉAN } & Lusitanoceras - Lyrogoniatites & \\
\hline & & Arnsbergites - Neoglyphioceras & \\
\hline & & Goniatites - Eoglyphioceras & \\
\hline & & Entogonites & \\
\hline & & (Bollandites - Bollandoceras) & \\
\hline & \multirow{4}{*}{ TOURNAISIAN } & Fascipericyclus-Ammonellipsites & \\
\hline & & Pericyclus-Progoniatites & \\
\hline & & Goniocyclus-Protocanites & \\
\hline & & Gattendorfia-Eocanites & \\
\hline
\end{tabular}

Figure 3. Stratigraphic scheme of the Early Carboniferous (Mississippian) chronostratigraphy and ammonoid zonation, with correlation of the North African ammonoid assemblages (after Korn et al. 2004, 2007). Highlighted the position of the assemblages from the Argiles de Timimoun. 
hammatocyclus (stratigraphically in the middle of the three samples) allows a correlation with the Arundian Chaigley Limestone of Northern England. Another criterion for a correlation of the assemblages from Timimoun is the lack of characteristic Late Viséan genera such as Goniatites and Entogonites (Korn 1988, 1997; Korn et al. 2005). We therefore propose an Early and Middle Viséan age for the assemblages (Fig. 3).

\section{Material}

A total of more than 1,000 specimens were investigated from the Argiles de Timimoun, 870 of these were examined in detail. They were collected during two field sessions 2002 and 2003 from three localities belonging to three different horizons. The material is deposited in the fossil cephalopod collection of the Museum für Naturkunde, Berlin (MB.C. prefix).

Locality and sample TIM-B2, $10 \mathrm{~km}$ west-southwest of Timimoun $\left(29.2292^{\circ} \mathrm{N} ; 0.1356^{\circ}\right.$ E); $140 \mathrm{~m}$ below the top of the Argiles de Timimoun inférieur:

Rhnetites rhnetensis $\mathrm{n}$. sp.

Rhnetites ouladallalensis $\mathrm{n}$. $\mathrm{sp}$.

Bollandoceras nitens $\mathrm{n}$. sp.

Bollandoceras subangulare n. sp.

Benimehlalites belkassemensis n. $\mathrm{sp}$.

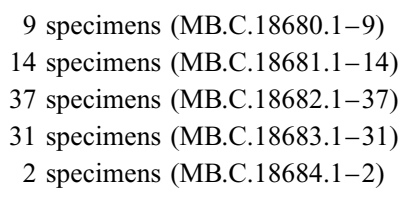

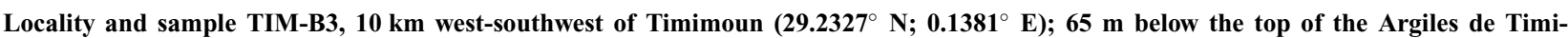
moun inférieur:

Parahammatocyclus mutaris n. sp. 7 specimens (MB.C.18685.1-7)

Bollandoceras politum n. sp. 12 specimens (MB.C.18686.1-12)

Bollandoceras aridum n. sp. $\quad 8$ specimens (MB.C.18687.1-8)

Benimehlalites brinkmanni n. sp. 11 specimens (MB.C.18688.1-11)

Benimehlalites benimehlalensis n. sp. $\quad 9$ specimens (MB.C.18689.1-9)

Daaites daaensis n. sp. 11 specimens (MB.C.18690.1-11)

Locality and sample TIM-C8, $13.3 \mathrm{~km}$ west of Timimoun $\left(29.2533^{\circ} \mathrm{N} ; \mathbf{0 . 0 9 5 3}^{\circ} \mathrm{E}\right)$; base of the Argiles de Timimoun supérieur:

Bollandoceras zuhara n. sp.

Bollandoceras mirrih n. sp.

Pachybollandoceras intraevolutum n. sp.

Pachybollandoceras repens $\mathrm{n}$. $\mathrm{sp}$.

Gourarites hagaraswad n. sp.

Gourarites hagarkarim n. sp.

Gourarites mustari n. sp.

Gourarites zuhal n. sp.

Semibollandites kamil n. sp.

Semibollandites pauculus n. sp.

Semibollandites qawiy $\mathrm{n}$. sp.

Timimounia timimounensis $\mathrm{n}$. $\mathrm{sp}$.

Timimounia lunula n. sp.

Dimorphoceras lanceolobatum n. sp.

Nomismoceras salim n. sp.

Nomismoceras waltoni $\mathrm{n}$. $\mathrm{sp}$.

Michiganites sp.

$$
\begin{array}{r}
108 \text { specimens (MB.C.18691.1-108) } \\
119 \text { specimens (MB.C.18692.1-119) } \\
16 \text { specimens (MB.C.18693.1-16) } \\
23 \text { specimens (MB.C.18694.1-23) } \\
53 \text { specimens (MB.C.18695.1-53) } \\
141 \text { specimens (MB.C.18696.1-141) } \\
26 \text { specimens (MB.C.18697.1-26) } \\
34 \text { specimens (MB.C.18698.1-34) } \\
37 \text { specimens (MB.C.18699.1-37) } \\
6 \text { specimens (MB.C.18700.1-6) } \\
55 \text { specimens (MB.C.18701.1-55) } \\
70 \text { specimens (MB.C.18702.1-70) } \\
83 \text { specimens (MB.C.18703.1-83) } \\
4 \text { specimens (MB.C.18704.1-4) } \\
25 \text { specimens (MB.C.18705.1-25) } \\
19 \text { specimens (MB.C.18706.1-19) } \\
1 \text { specimen (MB.C.18707) }
\end{array}
$$

\section{Systematic descriptions}

The descriptive part of this monograph will mainly focus on the illustration and morphometric analysis of the species with particular attention being paid to their ontoge- netic development. For this purpose, we produced more than 120 cross sections (of which nearly 80 are illustrated here). The key for the description of the species, including explanation of methods, is published by Korn (2010). Sutural terminology follows Korn et al. (2003a).

Suborder Goniatitina Hyatt, 1884

Superfamily Pericyclaceae Hyatt, 1900

Family Rotopericyclidae Korn, Bockwinkel \& Ebbighausen, 2010

Subfamily Rotopericyclinae Korn, Bockwinkel \& Ebbighausen, 2010

For a detailed diagnosis of the subfamily, see Korn et al. (2010a).

\section{Rhnetites n. gen.}

Derivation of name. After the village Rhnet, a suburb of Timimoun.

Type species. Rhnetites rhnetensis $\mathrm{n}$. $\mathrm{sp}$. 
Genus definition. Genus of the subfamily Rotopericyclinae with significant ontogenetic changes of the conch: conch ontogeny with minor to major ontogenetic transformations mainly of the opening rate of the umbilicus (Fig. 4); inner whorls subinvolute or involute, sudden opening of the umbilicus in the intermediate stage as a result of reduction of the whorl height and enlargement of the whorl width. Suture line with very narrow, subparallel external lobe with incurved flanks.

Included species.

ouladallalensis: Rhnetites ouladallalensis n. sp.: Gourara, Algeria.

rhnetensis: Rhnetites rhnetensis n. sp.: Gourara, Algeria.

Discussion. Rhnetites shows some similarities with Bollandites, but differs significantly in the development of the conch geometry. The conch ontogeny begins with an evolute stage in Bollandites and later stages show a more or less rapid decrease of the uw/dm ratio. Contrary to this, Rhnetites shows a striking rapid opening of the umbilicus in the middle growth stage, resulting in significantly higher uw/dm ratios.

The new genus resembles Benimehlalites in the striking ontogenetic trajectories with the sudden opening of the umbilicus in an intermediate or adult growth stage. The main differences between the two genera are the involute juvenile whorls in Rhnetites (which are subevolute in Benimehlalites) and the shape of the external lobe (with subparallel, incurved flanks in Rhnetites and diverging, sinuous flanks in Benimehlalites).

Eurites Kusina, 1974 and Trimorphoceras Ebbighausen, Korn \& Bockwinkel, 2010 differ in the narrower external lobe that possesses almost perfectly parallel flanks.
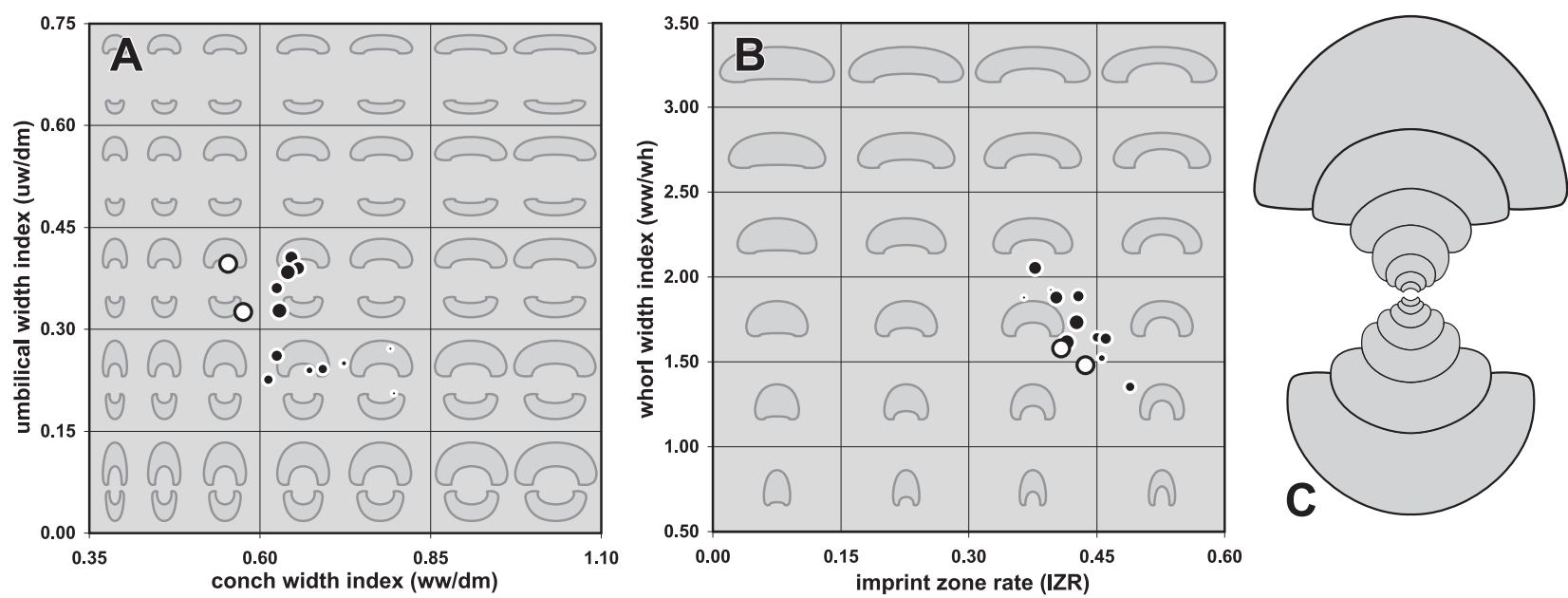

Figure 4. Ontogenetic trajectories of Rhnetites, exemplified for Rhnetites rhnetensis n. sp. from locality TIM-B2. A. Ontogenetic development of the conch width index (ww/dm) and umbilical width index (uw/dm). B. Ontogenetic development of the imprint zone rate (IZR) and whorl width index (ww/wh). C. Cross section of paratype MB.C.18680.3; $\times 2.5$. [Black dots represent ontogenetic stages of cross section MB.C.18680.3, white dots represent the reference specimens (Tab. 2).]

\section{Rhnetites rhnetensis n. sp.}

Figures 5, 6

Derivation of name. After the village Rhnet, a suburb of Timimoun.

Holotype. Specimen MB.C.18680.1, illustrated in Figure 5A.

Type locality and horizon. Sebkha de Timimoun, locality TIM-B2 (10 km west-southwest of Timimoun, Algeria); lower part of the Lower Bollandoceras-Bollandites Assemblage.

Material. Nine specimens, conch diameter between 13 and $25 \mathrm{~mm}$.

Diagnosis. Rhnetites with moderately strong ontogenetic changes of conch geometry: conch pachyconic in the early juvenile stage and continuously becoming discoidal at $20 \mathrm{~mm} \mathrm{dm}$; juvenile stage subinvolute with opening of the umbilicus at $6 \mathrm{~mm}$ dm, subevolute above $8 \mathrm{~mm}$ dm;

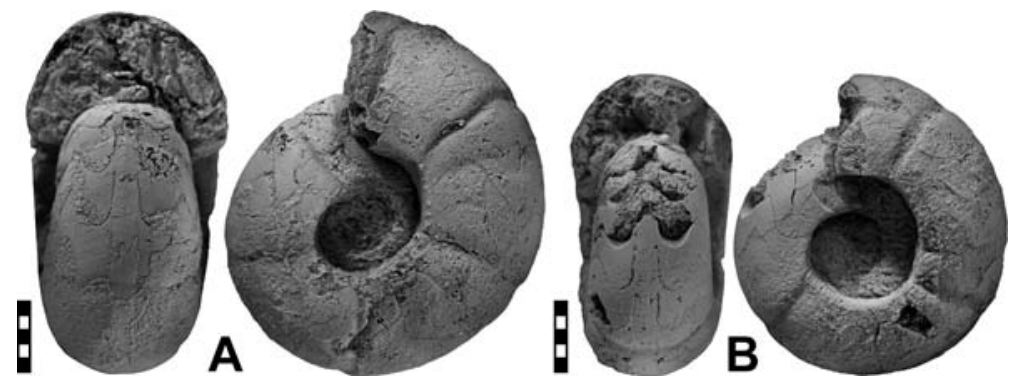

Figure 5. Rhnetites rhnetensis n. sp. from locality TIM-B2; all $\times 1.5$. A. Holotype MB.C.18680.1. B. Paratype MB.C.18680.2. 
aperture low in all stages except for an early juvenile stage with moderately high aperture; umbilical margin rounded in juveniles and angular in the adult stage. Steinkern with almost straight constrictions. Suture line with very narrow external lobe with subparallel flanks and very low to low median saddle; ventrolateral saddle broadly rounded, asymmetric; adventive lobe broadly V-shaped, symmetric with gently curved flanks.

Table 1. Conch ontogeny (Figs 6A-C, F-H) of Rhnetites rhnetensis n. sp.

\begin{tabular}{|c|c|c|c|}
\hline$d m$ & conch shape & whorl cross section shape & aperture \\
\hline 3 mm & $\begin{array}{l}\text { thinly to thickly pachyconic; subinvolute } \\
\text { (ww/dm }=0.65-0.75 ; \mathrm{uw} / \mathrm{dm}=0.15-0.25 \text { ) }\end{array}$ & $\begin{array}{l}\text { weakly to moderately depressed; very strongly } \\
\text { embracing ( } w w / w h=1.45-1.55 ; \mathrm{IZR}=0.45-0.50 \text { ) }\end{array}$ & $\begin{array}{l}\text { low to moderate } \\
(\mathrm{WER}=1.70-1.85)\end{array}$ \\
\hline $8 \mathrm{~mm}$ & $\begin{array}{l}\text { thinly pachyconic; subevolute } \\
(\mathrm{ww} / \mathrm{dm}=0.60-0.70 ; \mathrm{uw} / \mathrm{dm}=0.30-0.40)\end{array}$ & $\begin{array}{l}\text { moderately depressed; strongly to very strongly } \\
\text { embracing ( } w w / w h=1.80-2.00 ; I Z R=0.40-0.50 \text { ) }\end{array}$ & $\begin{array}{l}\text { low } \\
(\text { WER }=1.50-1.60)\end{array}$ \\
\hline 20 mm & $\begin{array}{l}\text { thickly discoidal to thinly pachyconic; subevolute } \\
\text { (ww/dm }=0.55-0.65 ; \mathrm{ww} / \mathrm{dm}=0.30-0.40 \text { ) }\end{array}$ & $\begin{array}{l}\text { moderately depressed; strongly embracing } \\
\text { (ww/wh }=1.50-1.70 ; \text { IZR }=0.40-0.45 \text { ) }\end{array}$ & $\begin{array}{l}\text { low } \\
(\text { WER }=1.55-1.70)\end{array}$ \\
\hline
\end{tabular}

Table 2. Conch dimensions (in $\mathrm{mm}$ ) and proportions for reference specimens of Rhnetites rhnetensis n. sp.

\begin{tabular}{lllllllllll}
\hline & $\mathrm{dm}$ & ww & wh & uw & ah & ww/dm & ww/wh & uw/dm & WER & IZR \\
\hline holotype MB.C.18680.1 & 24.5 & 14.1 & 9.5 & 8.0 & 5.4 & 0.58 & 1.48 & 0.33 & 1.64 & 0.44 \\
paratype MB.C.18680.2 & 20.3 & 11.3 & 7.1 & 8.1 & 4.2 & 0.55 & 1.58 & 0.40 & 1.59 & 0.41 \\
\hline
\end{tabular}

Table 3. Suture line proportions (Figs 6D, E) for Rhnetites rhnetensis n. sp.

\begin{tabular}{llllllll}
\hline specimen & at dm & EL w/d & EL/NLS & EL/AL & MS h & VLS w/h & remarks \\
\hline holotype MB.C.18680.1 & $20.0 \mathrm{~mm}$ & 0.43 & 0.52 & 0.64 & 0.19 & 0.82 & A lobe slightly pouched \\
\hline paratype MB.C.18680.5 & $6.0 \mathrm{~mm}$ & 0.55 & 0.75 & 0.83 & 0.28 & 0.74 & A \\
\hline
\end{tabular}
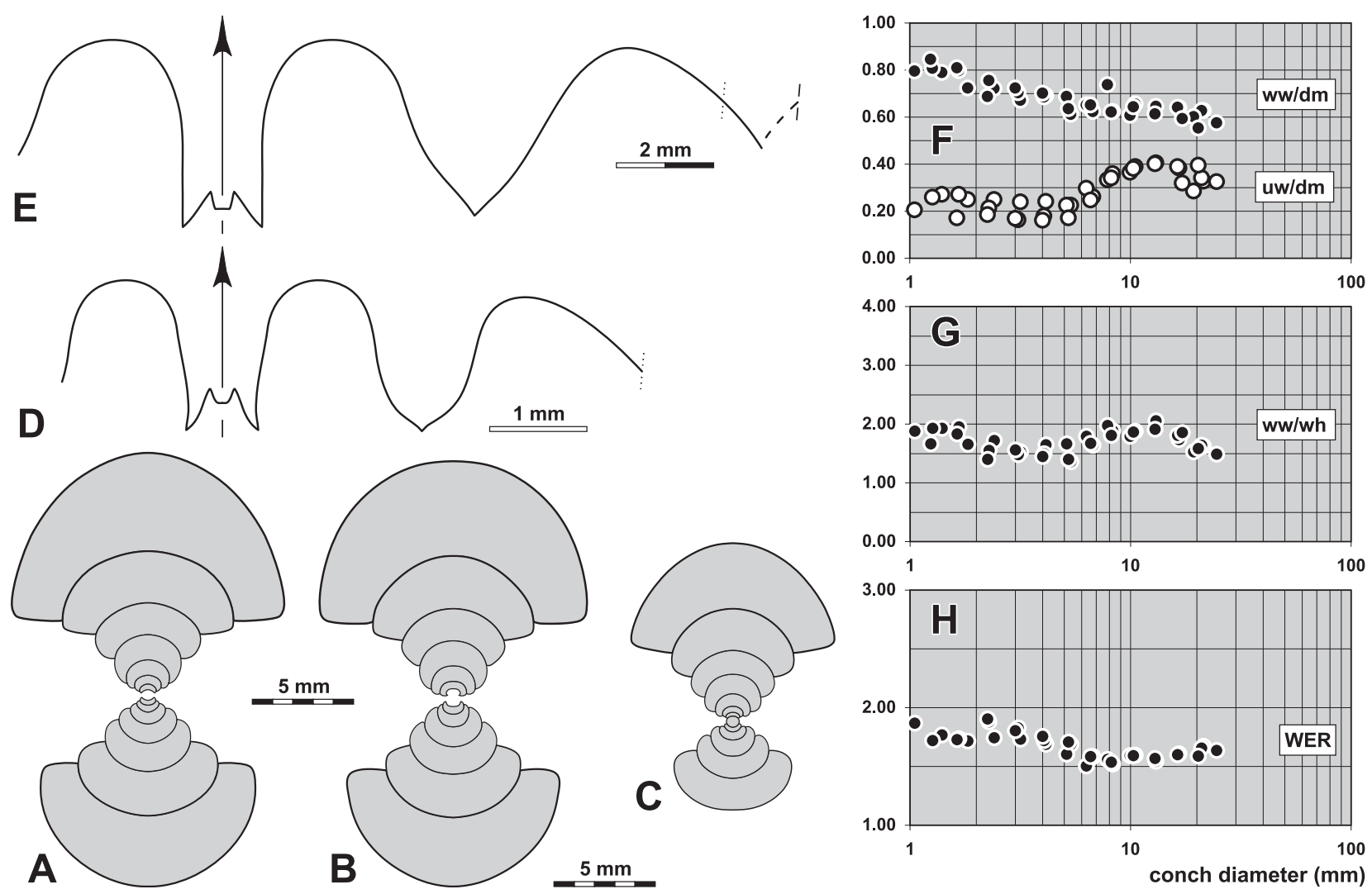

Figure 6. Rhnetites rhnetensis n. sp. from locality TIM-B2. A. Cross section of paratype MB.C.18680.3; $\times 2.5$. B. Cross section of paratype MB.C.18680.4; $\times 2.5$. C. Cross section of paratype MB.C.18680.5; $\times 2.5$. D. Suture line of paratype MB.C.18680.5, at $6.0 \mathrm{~mm} \mathrm{dm}, 4.0 \mathrm{~mm}$ ww, $2.5 \mathrm{~mm}$ wh; $\times 12.0$. E. Suture line of holotype MB.C. 18680.1 , at $20.0 \mathrm{~mm} \mathrm{dm}, 13.0 \mathrm{~mm} \mathrm{ww}, 10.0 \mathrm{~mm}$ wh; $\times 6.0$. F-H. Ontogenetic development of the conch width index $(\mathrm{ww} / \mathrm{dm})$, umbilical width index (uw/dm), whorl width index (ww/wh), and whorl expansion rate (WER) of all available specimens. 
Discussion. The two species Rhnetites rhnetensis and Rhnetites ouladallalensis are very similar and are best separated by their ontogenetic traits. The umbilicus begins to widen at $10 \mathrm{~mm}$ conch diameter in Rhnetites ouladallalensis, but already at $6 \mathrm{~mm} \mathrm{dm}$ in Rhnetites rhnetensis. Additionally, the aperture is much higher in Rhnetites ouladallalensis (WER $=2.00$ at $20 \mathrm{~mm} \mathrm{dm}$ ) than in Rhnetites rhnetensis (WER $=1.60$ at $20 \mathrm{~mm} \mathrm{dm}$ ).

\section{Rhnetites ouladallalensis $\mathbf{n}$. sp.}

Figures 7, 8

Derivation of name. After the village Oulad Allal, a suburb of Timimoun.

Holotype. Specimen MB.C.18681.1, illustrated in Figure 7.

Type locality and horizon. Sebkha de Timimoun, locality TIM-B2 (10 km west-southwest of Timimoun, Algeria); lower part of the Lower Bollandoceras-Bollandites Assemblage.

Material. 14 specimens, conch diameter between 13 and $25 \mathrm{~mm}$.

Diagnosis. Rhnetites with minor ontogenetic changes of conch geometry: conch pachyconic throughout ontogeny with slight increase of the whorl width index between 5 and $12 \mathrm{~mm} \mathrm{dm}$; juvenile stage subinvolute with opening of the umbilicus at $8 \mathrm{~mm}$ dm, subevolute above $12 \mathrm{~mm}$ dm; aperture low in all stages except for an early juvenile stage with moderately high aperture; umbilical margin rounded in juveniles and angular in the adult stage. Ornament with fine growth lines standing in wide distances, course concavo-convex with shallow ventral sinus; steinkern with concavoconvex constrictions standing in irregular distances of approximately $90^{\circ}$. Suture line with very narrow, barely diverging external lobe with slightly incurved flanks and very low median saddle; ventrolateral saddle rounded; adventive lobe V-shaped, symmetric and slightly pouched.

Table 4. Conch ontogeny (Figs 8A-C, E-G) of Rhnetites ouladallalensis n. sp.

\begin{tabular}{|c|c|c|c|}
\hline $\mathrm{dm}$ & conch shape & whorl cross section shape & aperture \\
\hline $3 \mathrm{~mm}$ & $\begin{array}{l}\text { thinly to thickly pachyconic; subinvolute } \\
\text { (ww/dm }=0.65-0.75 ; \mathrm{uw} / \mathrm{dm}=0.15-0.25 \text { ) }\end{array}$ & $\begin{array}{l}\text { weakly to moderately depressed; strongly to } \\
\text { very strongly embracing } \\
\text { (ww/wh }=1.45-1.65 ; \mathrm{IZR}=0.40-0.50 \text { ) }\end{array}$ & $\begin{array}{l}\text { low to moderate } \\
(\mathrm{WER}=1.65-2.00)\end{array}$ \\
\hline $8 \mathrm{~mm}$ & $\begin{array}{l}\text { thinly pachyconic; subinvolute } \\
(\mathrm{ww} / \mathrm{dm}=0.62-0.70 ; \mathrm{uw} / \mathrm{dm}=0.20-0.25 \text { ) }\end{array}$ & $\begin{array}{l}\text { moderately depressed; very strongly embracing } \\
(\mathrm{ww} / \mathrm{wh}=1.50-1.75 ; \mathrm{IZR}=0.45-0.50)\end{array}$ & $\begin{array}{l}\text { low } \\
(\text { WER }=1.60-1.75)\end{array}$ \\
\hline $20 \mathrm{~mm}$ & $\begin{array}{l}\text { thinly pachyconic; subevolute } \\
(\mathrm{ww} / \mathrm{dm}=0.60-0.70 ; \mathrm{uw} / \mathrm{dm}=0.35-0.40)\end{array}$ & $\begin{array}{l}\text { moderately depressed; strongly embracing } \\
(\mathrm{ww} / \mathrm{wh}=1.80-2.00 ; \mathrm{IZR}=0.35-0.45)\end{array}$ & $\begin{array}{l}\text { low } \\
(\text { WER }=1.50-1.65)\end{array}$ \\
\hline
\end{tabular}

Table 5. Conch dimensions (in $\mathrm{mm}$ ) and proportions for reference specimens of Rhnetites ouladallalensis $\mathrm{n}$. $\mathrm{sp}$.

\begin{tabular}{lccccccccccc}
\hline & $\mathrm{dm}$ & ww & wh & uw & ah & ww/dm & ww/wh & uw/dm & WER & IZR \\
\hline holotype MB.C.18681.1 & 17.6 & 11.1 & 5.6 & 5.9 & 3.9 & 0.63 & 1.97 & 0.33 & 1.65 & 0.31 \\
paratype MB.C.18681.5 & 12.3 & 8.6 & 4.2 & 4.6 & 2.3 & 0.70 & 2.04 & 0.38 & 1.52 & 0.45 \\
\hline
\end{tabular}

Table 6. Suture line proportions (Fig. 8D) for Rhnetites ouladallalensis n. sp.

\begin{tabular}{llllllll}
\hline specimen & at dm & EL w/d & EL/VLS & EL/AL & MS h & VLS w/h & remarks \\
\hline holotype MB.C.18681.1 & $15.5 \mathrm{~mm}$ & 0.40 & 0.61 & 0.61 & 0.14 & 0.65 & A lobe wider than VL saddle \\
\hline
\end{tabular}

Discussion. For comparison with Rhnetites rhnetensis, see above.

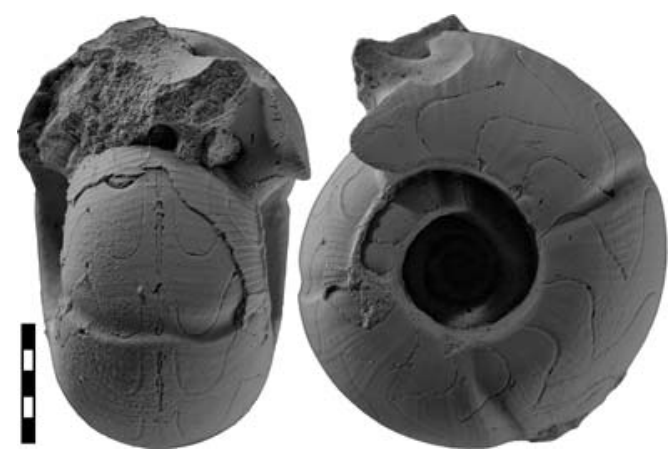

Figure 7. Rhnetites ouladallalensis $\mathrm{n}$. sp. from locality TIM-B2; holotype MB.C. $18681.1 ; \times 2.5$. 

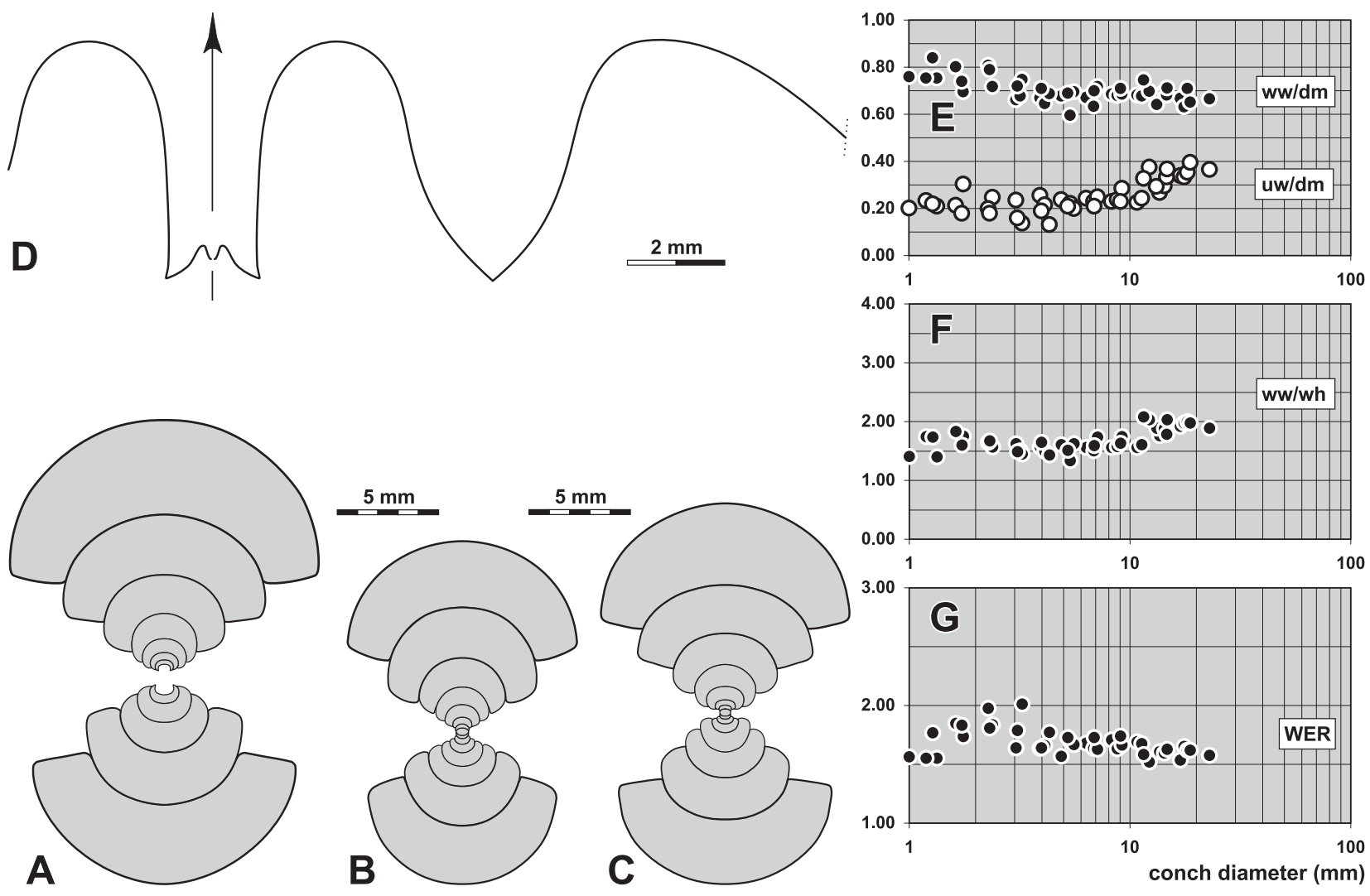

Figure 8. Rhnetites ouladallalensis n. sp. from locality TIM-B2. A. Cross section of paratype MB.C.18681.2; $\times 2.5$. B. Cross section of paratype MB.C.18681.3; $\times 2.5$. C. Cross section of paratype MB.C.18681.4; $\times 2.5$. D. Suture line of holotype MB.C.18681.1, at $15.5 \mathrm{~mm} \mathrm{dm}, 11.2 \mathrm{~mm}$ ww, $4.7 \mathrm{~mm}$ wh; $\times 6.0$. E-G. Ontogenetic development of the conch width index (ww/ $\mathrm{dm}$ ), umbilical width index (uw/dm), whorl width index (ww/wh), and whorl expansion rate (WER) of all available specimens.

\section{Parahammatocyclus Riley, 1996}

Type species. Parahammatocyclus chaigleyensis Riley, 1996

Diagnosis. Genus of the subfamily Rotopericyclinae with pachyconic, subevolute to evolute conch; conch ontogeny with increasing ww/dm ratio and decrease of the uw/dm ratio in the adult stage (Fig. 9). Suture line with very narrow, slightly diverging external lobe with slightly sinuous flanks and hook-shaped secondary prongs.
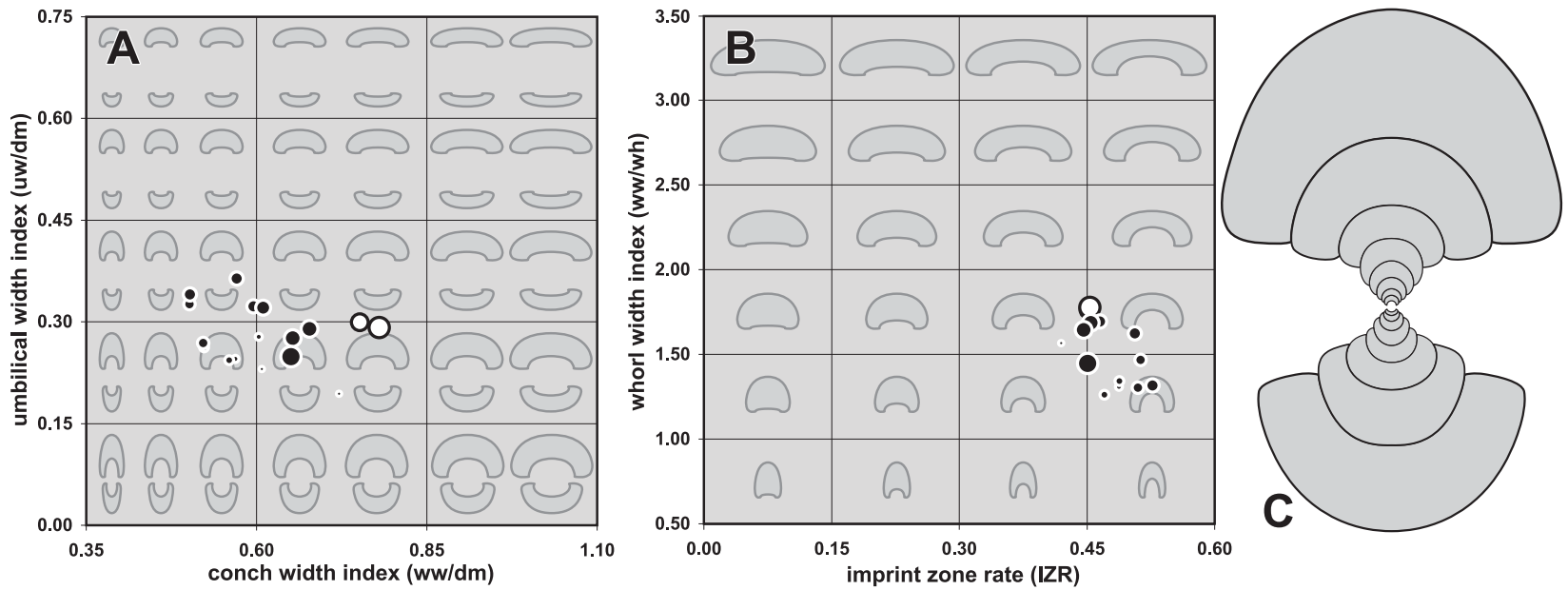

Figure 9. Ontogenetic trajectories of Parahammatocyclus, exemplified for Parahammatocyclus mutaris n. sp. from locality TIMB3. A. Ontogenetic development of the conch width index (ww/dm) and umbilical width index (uw/dm). B. Ontogenetic development of the imprint zone rate (IZR) and whorl width index (ww/wh). C. Cross section of paratype MB.C.18685.3; $\times 2.0$. [Black dots represent ontogenetic stages of cross section MB.C.18685.3, white dots represent the reference specimens (Tab. 8).] 
Included species.

chaigleyensis: Parahammatocyclus chaigleyensis Riley, 1996: Lancashire. Great Britain.

mutaris: Parahammatocyclus mutaris n. sp.: Gourara, Algeria.

Discussion. Parahammatocyclus differs from Rhnetites n. gen. in the wider, more narrowly umbilicate conch and particularly in the diverging flanks of the external lobe. Bollandites has a superficially similar conch, but differs in the closure of the umbilicus, which in Parahammatocyclus continuously becomes wider during ontogeny.

\section{Parahammatocyclus mutaris n. sp.}

Figures 10, 11

Derivation of name. From Latin mutaris $=$ to transmute, because of the striking ontogeny.

Holotype. Specimen MB.C.18685.1, illustrated in Figure 10A.

Type locality and horizon. Sebkha de Timimoun, locality TIM-B3 (10 km west-southwest of Timimoun, Algeria); upper part of the Lower Bollandoceras-Bollandites Assemblage.

Material. Seven specimens, conch diameter between 19 and $42 \mathrm{~mm}$.

Diagnosis. Parahammatocyclus with thickly discoidal and subinvolute conch at $2-5 \mathrm{~mm} \mathrm{dm}$, becoming pachyconic and subevolute in later stages; aperture very low or low up to $18 \mathrm{~mm} \mathrm{dm}$ and slightly increasing in the adult stage; umbilical margin rounded in juveniles but angular and sharp in the middle and adult stage. Steinkern smooth except for shallow, almost linear constrictions in small stages; in the middle stage the steinkern possesses faint umbilical nodes. Suture line with very narrow, slightly diverging external lobe with sinuous flanks and low median saddle; ventrolateral saddle broadly rounded; adventive lobe symmetrically V-shaped and slightly pouched.

Table 7. Conch ontogeny (Figs 11A, B, D-F) of Parahammatocyclus mutaris n. sp.

\begin{tabular}{|c|c|c|c|}
\hline $\mathrm{dm}$ & conch shape & whorl cross section shape & aperture \\
\hline $3 \mathrm{~mm}$ & $\begin{array}{l}\text { thickly discoidal; subinvolute } \\
\text { (ww/dm } \sim 0.55 ; \text { uw/dm } \sim 0.25 \text { ) }\end{array}$ & $\begin{array}{l}\text { weakly depressed; very strongly embracing } \\
\text { (ww/wh } \sim 1.35 ; \text { IZR } \sim 0.50 \text { ) }\end{array}$ & $\begin{array}{l}\text { low } \\
(\text { WER } \sim 1.60)\end{array}$ \\
\hline $8 \mathrm{~mm}$ & $\begin{array}{l}\text { thickly discoidal; subevolute } \\
\text { (ww/dm }=0.50-0.60 ; \text { uw/dm }=0.30-0.35 \text { ) }\end{array}$ & $\begin{array}{l}\text { moderately depressed; very strongly embracing } \\
\text { (ww/wh }=1.50-1.65 ; \text { IZR }=0.50-0.55)\end{array}$ & $\begin{array}{l}\text { low } \\
(\text { WER }=1.50-1.55)\end{array}$ \\
\hline $20 \mathrm{~mm}$ & $\begin{array}{l}\text { thinly to thickly pachyconic; subinvolute to } \\
\text { subevolute (ww/dm }=0.65-0.80 \\
\text { uw/dm }=0.25-0.35 \text { ) }\end{array}$ & $\begin{array}{l}\text { moderately depressed; very strongly embracing } \\
(\mathrm{ww} / \mathrm{wh}=1.65-1.95 ; \mathrm{IZR}=0.45-0.50)\end{array}$ & $\begin{array}{l}\text { low } \\
(\text { WER }=1.60-1.75)\end{array}$ \\
\hline $35 \mathrm{~mm}$ & $\begin{array}{l}\text { thickly pachyconic; subinvolute } \\
(\mathrm{ww} / \mathrm{dm}=0.72-0.80 ; \mathrm{uw} / \mathrm{dm}=0.18-0.30)\end{array}$ & $\begin{array}{l}\text { moderately depressed; very strongly embracing } \\
(\mathrm{ww} / \mathrm{wh}=1.50-1.75 ; \mathrm{IZR}=0.45-0.50)\end{array}$ & $\begin{array}{l}\text { moderate } \\
(\mathrm{WER}=1.75-1.90)\end{array}$ \\
\hline
\end{tabular}

Table 8. Conch dimensions (in $\mathrm{mm}$ ) and proportions for reference specimens of Parahammatocyclus mutaris n. sp.

\begin{tabular}{llllllllllll}
\hline & $\mathrm{dm}$ & ww & wh & uw & ah & ww/dm & ww/wh & uw/dm & WER & IZR \\
\hline holotype MB.C.18685.1 & 36.6 & 28.5 & 16.0 & 10.7 & 8.8 & 0.78 & 1.78 & 0.29 & 1.73 & 0.45 \\
paratype MB.C.18685.2 & 24.4 & 18.4 & 10.4 & 7.3 & 5.7 & 0.75 & 1.76 & 0.30 & 1.70 & 0.45 \\
\hline
\end{tabular}

Table 9. Suture line proportions (Fig. 11C) for Parahammatocyclus mutaris n. sp.

\begin{tabular}{llllllll}
\hline specimen & at dm & EL w/d & EL/VLS & EL/AL & MS h & VLS w/h & remarks \\
\hline paratype MB.C.18685.5 & $25.8 \mathrm{~mm}$ & 0.41 & 0.56 & 0.79 & 0.25 & 0.73 & A lobe with slightly convex flanks \\
\hline
\end{tabular}

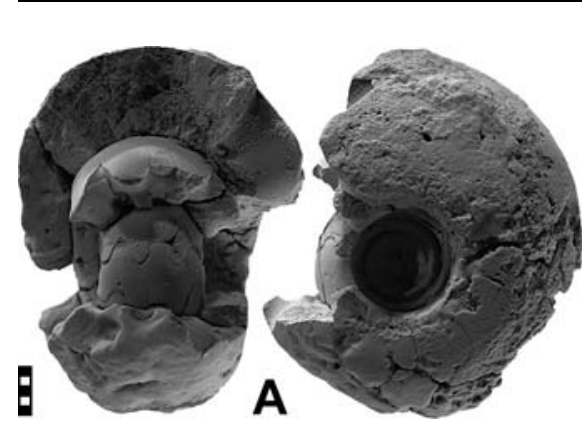

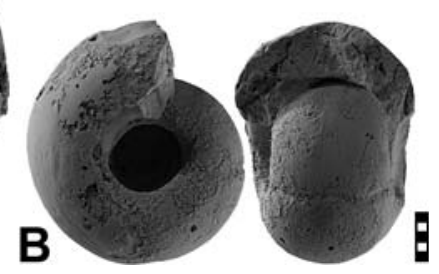

Figure 10. Parahammatocyclus mutaris n. sp. from locality TIM-B3; all $\times 1.0$. A. Holotype MB.C.18685.1. B. Paratype MB.C.18685.2. 
Discussion. Parahammatocyclus mutaris can easily be separated from the other species of the assemblage by its pachyconic conch and its wide umbilicus in the adult stage as well as by the very narrow external lobe. It differs from P. chaigleyensis Riley, 1996 in the much narrower umbilicus of the juvenile stage, the umbilical nodes, and the narrower external lobe.
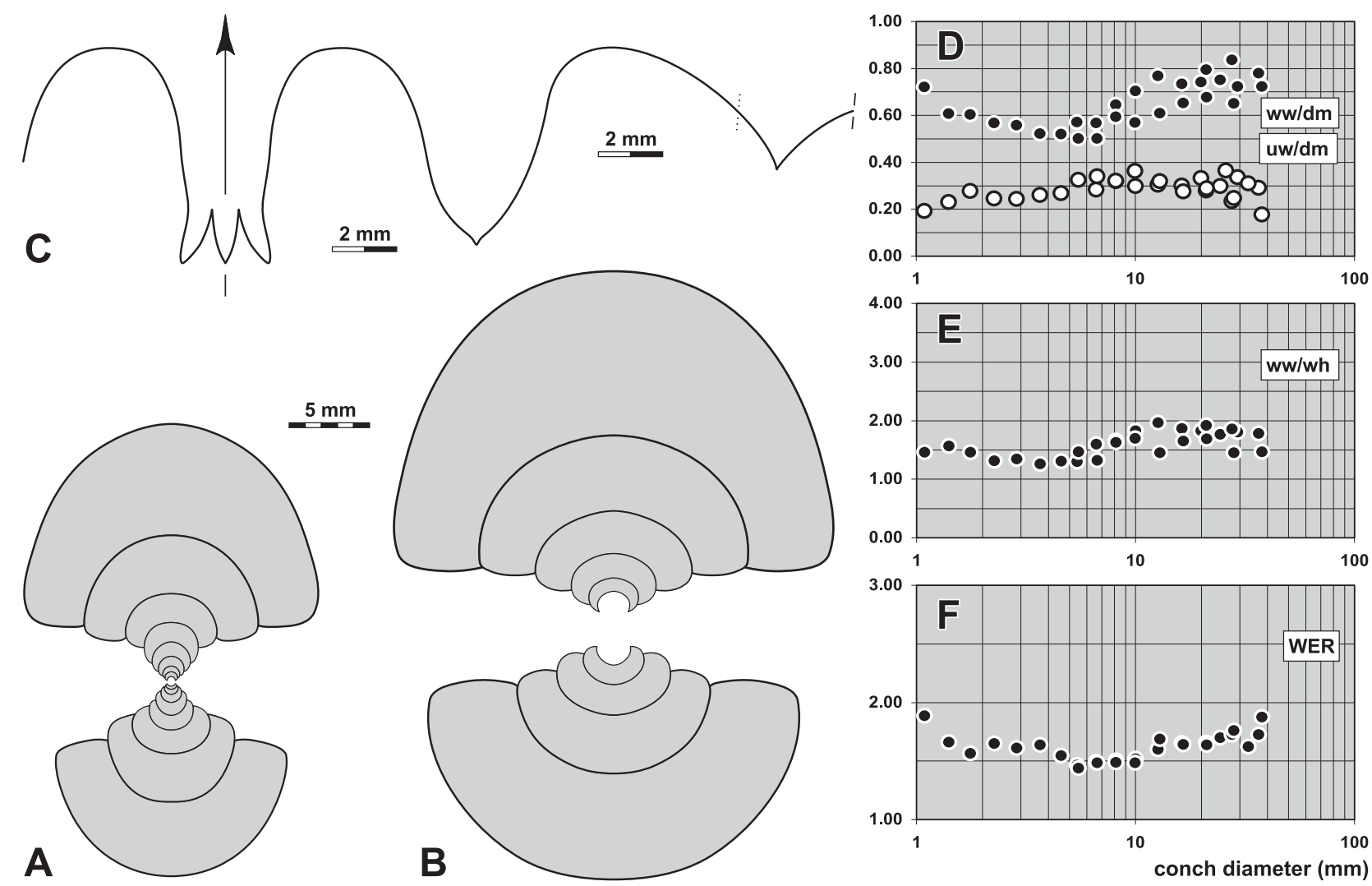

Figure 11. Parahammatocyclus mutaris n. sp. from locality TIM-B3. A. Cross section of paratype MB.C.18685.3; $\times 2.0$. B. Cross section of paratype MB.C.18685.4; $\times 2.0$. C. Suture line of paratype MB.C.18685.5, at $25.8 \mathrm{~mm} \mathrm{dm}, 20.0 \mathrm{~mm} w w, 10.0 \mathrm{~mm}$ wh; $\times$ 4.0. D-F. Ontogenetic development of the conch width index $(\mathrm{ww} / \mathrm{dm})$, umbilical width index (uw/dm), whorl width index (ww/ wh), and whorl expansion rate (WER) of all available specimens.

Family Maxigoniatitidae Korn, Klug \& Mapes, 1999

Subfamily Maxigoniatitinae Korn, Klug \& Mapes, 1999

Subfamily definition. Maxigoniatitidae with a widely umbilicate juvenile and intermediate stage with weakly or moderately depressed whorl cross section. Ornament usually with biconvex, fine growth lines and spiral lines in some genera. Suture line with V-shaped external lobe, flanks of the external lobe usually strongly sinuous.

Included genera.

Benimehlalites n. gen.

Beyrichoceras Foord, 1903

Bollandoceras Bisat, 1952

Maxigoniatites Korn, Klug \& Mapes, 1999

Pachybollandoceras $\mathrm{n}$. gen.

\section{Bollandoceras Bisat, 1952}

Type species. Goniatites micronotus Phillips, 1836 (original designation).

Genus definition. Genus of the subfamily Maxigoniatitinae with moderate to major ontogenetic changes of conch morphology (Figs 12, 13); adult conch discoidal with rapidly expanding whorls (WER above 2.10 in stages larger than 10 mm conch diameter); umbilicus moderately wide to wide in juveniles and narrow or almost closed in the adult stage. Shell ornament consisting of fine biconvex growth lines with a rather deep ventral sinus; steinkern often with constrictions parallel to the growth lines. Suture line with very narrow to narrow, V-shaped external lobe with gently sinuous, slightly diverging flanks; secondary prongs of the external lobe hook-shaped; median saddle very low or low; ventrolateral saddle usually broadly rounded; adventive lobe V-shaped, often much shallower than the external lobe. 


\section{Included species.}

aridum: Bollandoceras aridum n. sp.: Gourara, Algeria.

bashatchense: Bollandites bashatchensis Popov, 1965, p. 38. Tien Shan.

bellmanense: Dzhaprakoceras bellmanense Riley, 1996, p. 51. Lancashire.

boreus: Bollandites boreus Kusina, 1980, p. 60. North Urals.

crowdecotense: Bollandoceras crowdecotense Korn \& Tilsley, 2006, p. 131. Derbyshire.

fordi: Bollandoceras fordi Korn \& Tilsley, 2006, p. 127. Derbyshire.

furiense: Bollandoceras furiense Padget, 1952, p. 864. Ireland.

globosum: Bollandoceras globosum Bisat, 1952, p. 177. Yorkshire.

hodderense: Beyrichoceras hodderense Bisat, 1924, p. 84. Lancashire.

inopinum: Bollandoceras inopinum Ruzhencev, 1975, p. 39. Verkhoyan.

kaindynense: Bollandites ? kaindynense Popov, 1965, p. 40. Tien Shan.

librovitchi: Beyrichoceras librovitchi Popov, 1965, p. 43. Tien Shan.

mackellari: Beyrichoceras mackellari Campbell, Brown \& Coleman, 1983, p. 89. Queensland.

micronotoide: Bollandoceras micronotoides Bisat, 1934, p. 290. Yorkshire.

micronotum: Goniatites micronotus Phillips, 1836, p. 234. Yorkshire.

minusculum: Dzhaprakoceras ? minusculum Kusina, 1980, p. 55. North Urals.

mirrih: Bollandoceras mirrih n. sp.: Gourara, Algeria.

nitens: Bollandoceras nitens n. sp.: Gourara, Algeria.

parvum: Bollandoceras parvum Kusina in Kusina \& Lazarev, 1994, p. 166. Mongolia.

politum: Bollandoceras politum n. sp.: Gourara, Algeria.

stylense: Bollandoceras stylense Kusina in Kusina \& Poletaev, 1991, p. 40. Donets Basin.

subangulare: Bollandoceras subangulare n. sp.: Gourara, Algeria.

submicronotum: Bollandoceras submicronotum Bisat, 1934, p. 291. Derbyshire. [Synonym of B. micronotum]

suursureni: Bollandoceras suursureni Kusina in Kusina \& Lazarev, 1994, p. 167. Mongolia.

tianshanicum: Beyrichoceras tianshanicum Popov, 1965, p. 44. Tien Shan.

undulatum: Dzhaprakoceras undulatum Riley, 1996, p. 66. Lancashire.

westheadi: Dzhaprakoceras westheadi Riley, 1996, p. 66. Lancashire.

zuhara: Bollandoceras zuhara n. sp.: Gourara, Algeria.

Discussion. Bollandoceras was introduced for species related to Beyrichoceras, but lacking a spiral ornament and possessing a lower median saddle in the suture line. The three species originally included in the 'Beyrichoceras micronotum group' were separated by Bisat (1934) on the basis of conch morphology and the presence or absence of constrictions.

When Bisat (1952) created the genus Bollandoceras for this species group, he also added species such as "Goniatites excavatus Phillips, 1836" (which is a girtyoceratid ammonoid) and B. globosum Bisat, 1952. Riley (1996) followed this species concept, and also included B.hodderense (Bisat, 1924) and a number of other species in Bollandoceras. Such a definition of the genus would mean that two rather different and easily separable conch morphologies are united within one taxon: conchs with rapidly expanding whorls as in the type species, and conchs with slowly expanding whorls as in species such as "Beyrichoceras hodderense Bisat, 1924".

Popov (1968), Riley (1996), and Korn \& Tilsley (2006) published cross sections of species of Bollandoceras, but some of the species were described without knowledge of the morphology of the inner whorls. Numerous cross sections were therefore made as part of this study.
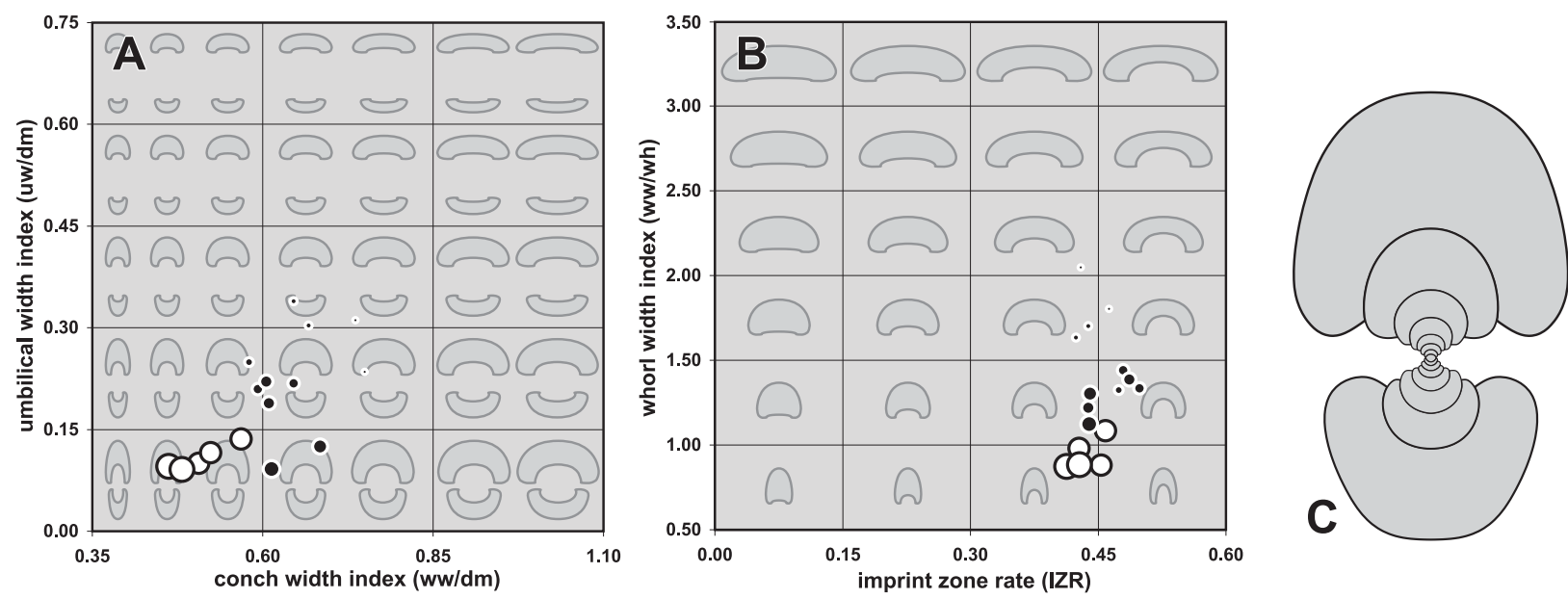

Figure 12. Ontogenetic trajectories of Bollandoceras, exemplified for Bollandoceras politum n. sp. from locality TIM-B3. A. Ontogenetic development of the conch width index (ww/dm) and umbilical width index (uw/dm). B. Ontogenetic development of the imprint zone rate (IZR) and whorl width index (ww/wh). C. Cross section of paratype MB.C.18686.4; $\times 2.5$. [Black dots represent ontogenetic stages of cross section MB.C.18686.4, white dots represent the reference specimens (Tab. 17).] 
Three of the species (B. bellmanense, B. undulatum, B. westheadi) described under the genus Dzhaprakoceras by Riley (1996) show an external lobe with diverging, slightly sinuous flanks and hook-shaped secondary prongs of the external lobe. They fall into the genus Bollandoceras, when the external lobe is the main distinguishing character between the two genera. The three species have a late Chadian age and co-occur with Ammonellipsites.

The new genus Gourarites resembles Bollandoceras in the adult conch, but differs in the presence of a juvenile growth stage with a very wide, crescent-shaped whorl cross section.
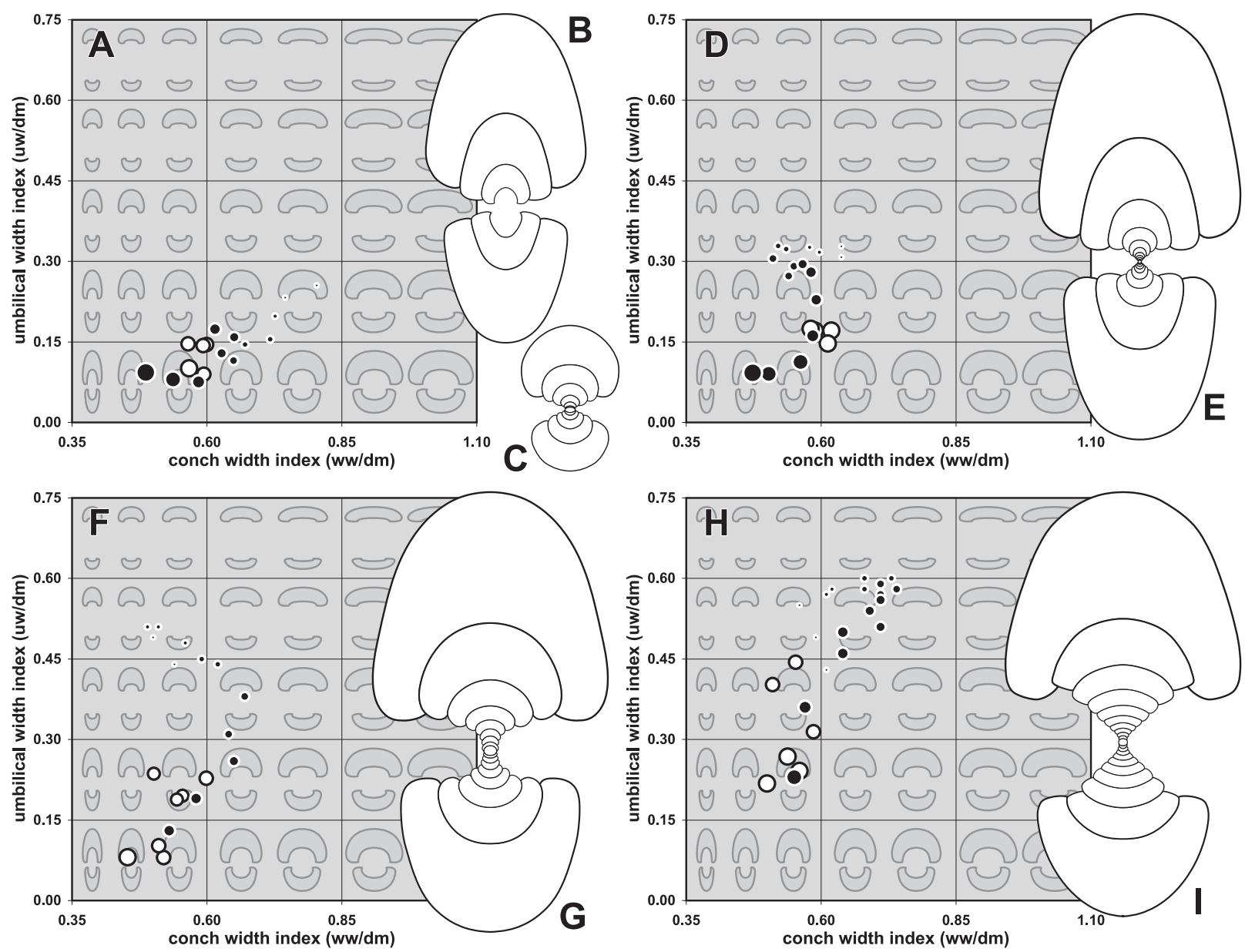

Figure 13. Ontogenetic trajectories in development of the conch width index (ww/dm) and umbilical width index (uw/dm) of Bollandoceras and Gourarites. A-C. B. nitens n. sp. from locality TIM-B2 with cross sections of paratypes MB.C.18682.10 (B; $\times 1.0)$ and MB.C.18682.8 (C; $\times 2.5)$. D, E. B. aridum n. sp. from locality TIM-B3 with cross sections of paratype MB.C.18687.3 $(\mathrm{E} ; \times 1.0)$. F, G. B. zuhara n. sp. from locality TIM-C8 with cross sections of paratype MB.C.18691.8 (G; ×4.0). H, I. G. zuhal n. sp. from locality TIM-C8 with cross sections of paratype MB.C.18698.3 (I; $\times 2.0)$. [Black dots represent ontogenetic stages of the figured cross sections, white dots represent the reference specimens listed in the tables of the species.]

\section{Bollandoceras nitens n. sp.}

Figures 14, 15

Derivation of name. From Latin nitens = shiny, because of the preservation.

Holotype. Specimen MB.C.18682.1, illustrated in Figure 14A.

Type locality and horizon. Sebkha de Timimoun, locality TIM-B2 (10 km west-southwest of Timimoun, Algeria); lower part of the Lower Bollandoceras-Bollandites Assemblage.

Material. 37 specimens, conch diameter between 12 and $45 \mathrm{~mm}$. Most of the specimens are fully chambered and exfoliated; the steinkern surface is usually smooth except for a few very weak constrictions and periodically strengthened growth lines that show faint impressions. Shell remains are rarely preserved in the material.

Diagnosis. Bollandoceras with minor ontogenetic changes of conch geometry: conch subinvolute to involute throughout ontogeny with a trend towards decrease of the uw/dm ratio in the adult stage; conch becoming almost continuously more slender during ontogeny: thickly pachyconic in the early juvenile stage and discoidal at $45 \mathrm{~mm} \mathrm{dm}$, decrease of the ww/dm ratio slightly decelerated between 3 and $13 \mathrm{~mm}$ dm; aperture moderately high in juveniles and becoming higher in later ontogeny; umbilical margin rounded in juveniles and subangular in the adult stage; umbilical wall flattened and oblique in the adult stage. Ornament with fine growth lines, course slightly biconvex with moderately deep ventral 
sinus; steinkern smooth except for shallow constrictions standing in irregular distances or $90^{\circ}$ apart. Suture line with very narrow, slightly diverging external lobe with slightly sinuous flanks and low median saddle; ventrolateral saddle broadly rounded; adventive lobe V-shaped, slightly asymmetric.

Table 10. Conch ontogeny (Figs 15A-E, H-J) of Bollandoceras nitens n. sp.

\begin{tabular}{|c|c|c|c|}
\hline $\mathrm{dm}$ & conch shape & whorl cross section shape & aperture \\
\hline $3 \mathrm{~mm}$ & $\begin{array}{l}\text { thinly to thickly pachyconic; involute to subinvolute } \\
\text { (ww/dm }=0.65-0.75 ; \text { uw } / \mathrm{dm}=0.10-0.25 \text { ) }\end{array}$ & $\begin{array}{l}\text { weakly to moderately depressed; strongly to } \\
\text { very strongly embracing } \\
(\mathrm{ww} / \mathrm{wh}=1.35-1.65 ; \mathrm{IZR}=0.40-0.50)\end{array}$ & $\begin{array}{l}\text { moderate } \\
(\mathrm{WER}=1.75-2.00)\end{array}$ \\
\hline $8 \mathrm{~mm}$ & $\begin{array}{l}\text { thinly pachyconic; subinvolute } \\
\text { (ww/dm }=0.60-0.70 ; \mathrm{uw} / \mathrm{dm}=0.15-0.25 \text { ) }\end{array}$ & $\begin{array}{l}\text { weakly to moderately depressed; strongly to } \\
\text { very strongly embracing } \\
(\mathrm{ww} / \mathrm{wh}=1.30-1.60 ; \mathrm{IZR}=0.40-0.50)\end{array}$ & $\begin{array}{l}\text { moderate } \\
(\mathrm{WER}=1.75-2.00)\end{array}$ \\
\hline $20 \mathrm{~mm}$ & $\begin{array}{l}\text { thickly discoidal to thinly pachyconic; involute } \\
(\mathrm{ww} / \mathrm{dm}=0.55-0.65 ; \mathrm{uw} / \mathrm{dm}=0.08-0.15)\end{array}$ & $\begin{array}{l}\text { weakly depressed; strongly embracing } \\
(\text { ww/wh }=1.00-1.25 ; \text { IZR }=0.40-0.45)\end{array}$ & $\begin{array}{l}\text { moderate to high } \\
(\text { WER }=1.90-2.20)\end{array}$ \\
\hline $40 \mathrm{~mm}$ & $\begin{array}{l}\text { thickly discoidal to thinly pachyconic; involute } \\
\text { (ww/dm } \sim 0.50 ; \mathrm{uw} / \mathrm{dm} \sim 0.08 \text { ) }\end{array}$ & $\begin{array}{l}\text { weakly compressed; strongly embracing } \\
\text { (ww/wh } \sim 0.95 ; \text { IZR } \sim 0.42 \text { ) }\end{array}$ & $\begin{array}{l}\text { high } \\
\text { (WER 2.05) }\end{array}$ \\
\hline
\end{tabular}

Table 11. Conch dimensions (in $\mathrm{mm}$ ) and proportions for reference specimens of Bollandoceras nitens $\mathrm{n}$. $\mathrm{sp}$.

\begin{tabular}{lcccccccccc}
\hline & $\mathrm{dm}$ & ww & wh & uw & ah & ww/dm & ww/wh & uw/dm & WER & IZR \\
\hline holotype MB.C.18682.1 & 33.1 & 18.7 & 18.2 & 3.3 & 10.5 & 0.57 & 1.03 & 0.10 & 2.15 & 0.42 \\
paratype MB.C.18682.2 & 23.5 & 13.9 & 11.8 & 3.4 & 7.2 & 0.59 & 1.18 & 0.14 & 2.08 & 0.39 \\
paratype MB.C.18682.4 & 20.4 & 11.5 & 10.4 & 3.0 & 5.6 & 0.57 & 1.11 & 0.15 & 1.91 & 0.46 \\
paratype MB.C.18682.11 & 18.6 & 11.1 & 10.3 & 1.7 & 6.0 & 0.59 & 1.08 & 0.09 & 2.18 & 0.41 \\
paratype MB.C.18682.3 & 18.5 & 11.1 & 9.0 & 2.7 & 5.4 & 0.60 & 1.23 & 0.15 & 1.99 & 0.40 \\
\hline
\end{tabular}

Table 12. Suture line proportions (Figs 15F, G) for Bollandoceras nitens n. sp.

\begin{tabular}{llllllll}
\hline specimen & at dm & EL w/d & EL/NLS & EL/AL & MS h & VLS w/h remarks \\
\hline holotype MB.C.18682.1 & $28.5 \mathrm{~mm}$ & 0.47 & 0.71 & 0.80 & 0.20 & 0.67 & A lobe almost symmetric \\
paratype MB.C.18682.5 & $21.0 \mathrm{~mm}$ & 0.46 & 0.67 & 0.80 & 0.21 & 0.68 & \\
\hline
\end{tabular}

Discussion. Bollandoceras nitens belongs together with the other species of the genus, which possess a very short openly umbilicate juvenile stage and which also have a very narrow external lobe. The new species differs, for instance, from the rather similar species B. politum of the next higher horizon near Timimoun in the narrower umbilicate inner whorls and the narrower external lobe $(\mathrm{EL} / \mathrm{h}=0.45$ in B. nitens and 0.55 in B. politum) and in the stouter conch. B. aridum has a similar conch but differs in the wider umbilicate juvenile stage and the wider external lobe. The co-occurring B. subangulare has a wider umbilicus (uw/dm $>0.20$ at $20 \mathrm{~mm} \mathrm{dm}$ ).
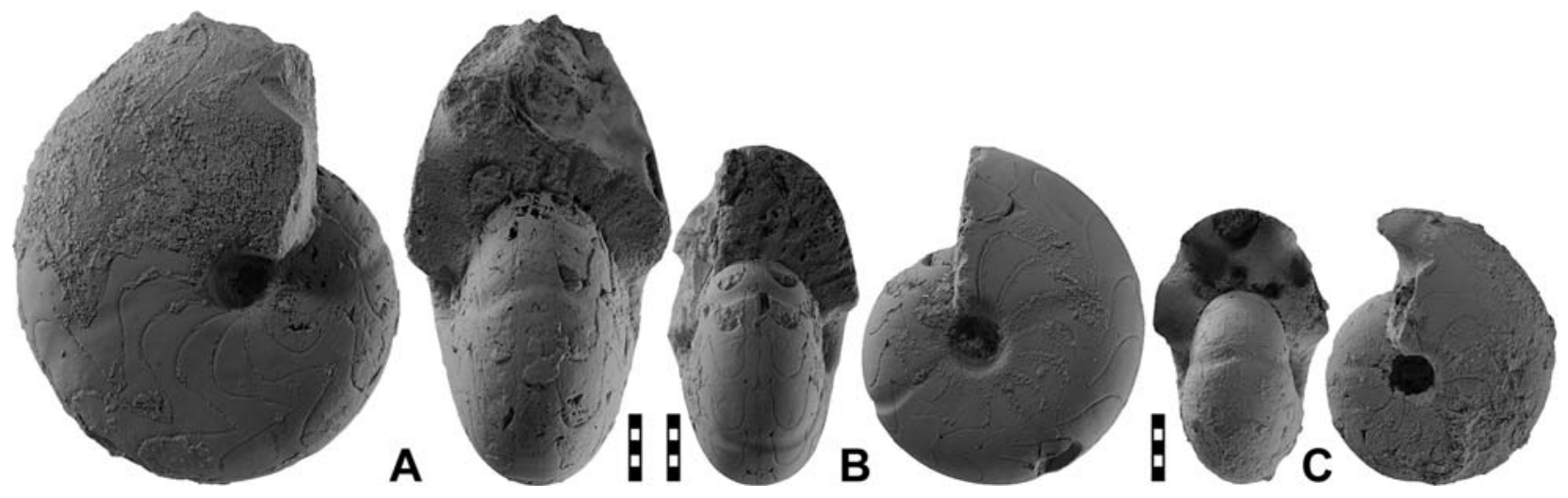

Figure 14. Bollandoceras nitens n. sp. from locality TIM-B2; all × 1.5. A. Holotype MB.C.18682.1. B. Paratype MB.C.18682.2. C. Paratype MB.C.18682.4. 
Species probably belonging to Bollandoceras have been described by Popov $(1965,1968)$ from the Tien Shan of Kyrgyzstan under the genus name Bollandites. Popov had only a few specimens and hence it is not clear if all the species described by him are justified or represent intraspecific variability. However, three of the species $(B$. bashatchensis, B. narynensis, and B. shabyrensis) possess an external lobe with almost parallel flanks, and $B$. kokdzharensis has a much more compressed conch.

Some of the species attributed to Dzhaprakoceras by Riley (1996) probably also belong to Bollandoceras. Of these, $B$. undulatum, $B$. westheadi, and $B$. bellmanense show a wider umbilicus than $B$. nitens.
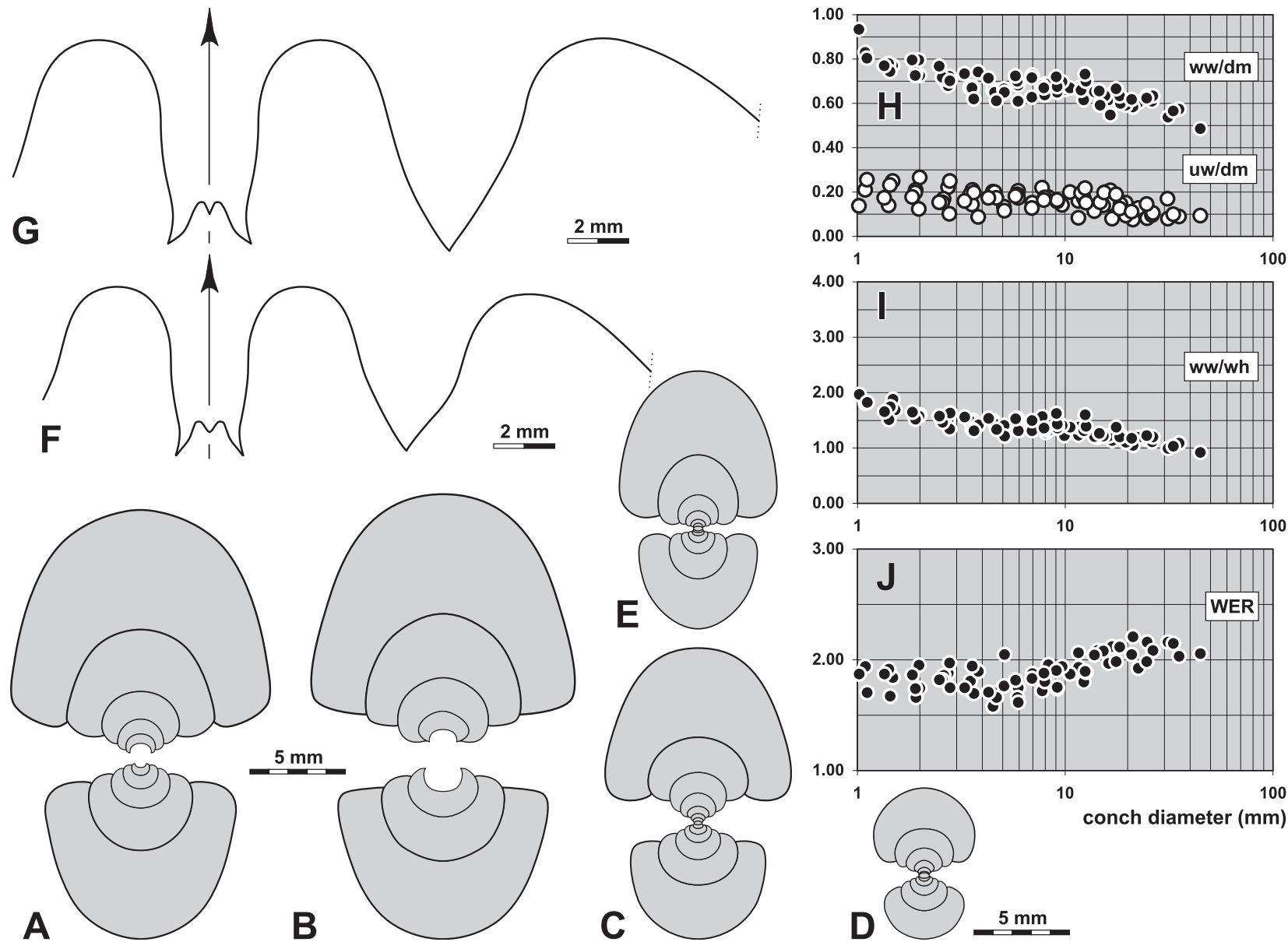

$5 \mathrm{~mm}$

A
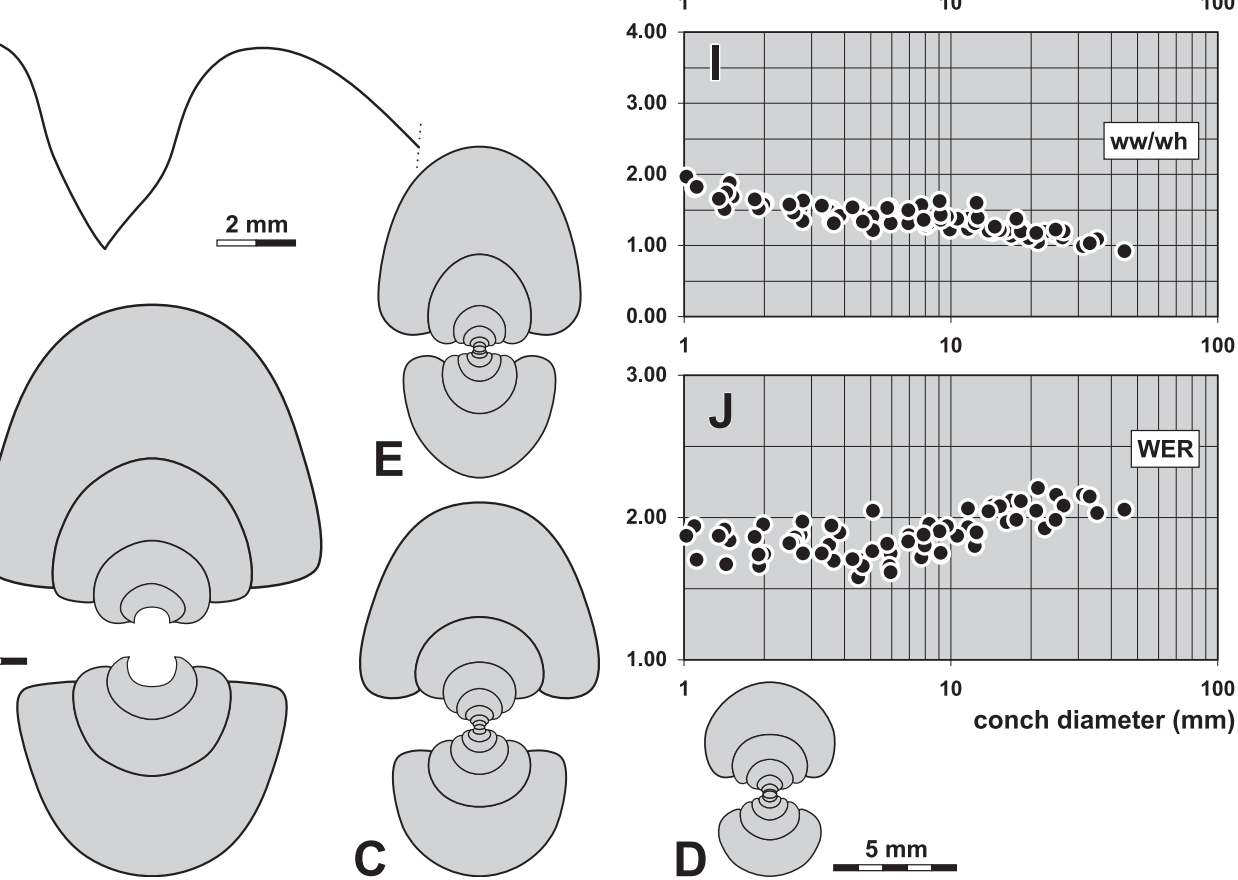

Figure 15. Bollandoceras nitens $n$. sp. from locality TIM-B2. A. Cross section of paratype MB.C.18682.5; $\times 2.5$. B. Cross section of paratype MB.C.18682.6; $\times 2.5$. C. Cross section of paratype MB.C.18682.7; $\times 2.5$. D. Cross section of paratype MB.C.18682.8; $\times 2.5$. E. Cross section of paratype MB.C. $18682.9 ; \times 2.5$. F. Suture line of paratype MB.C. 18682.5 , at $21.0 \mathrm{~mm} \mathrm{dm}, 12.5 \mathrm{~mm}$ ww, $10.5 \mathrm{~mm}$ wh; $\times 4.0$. G. Suture line of holotype MB.C.18682.1, at $28.5 \mathrm{~mm} \mathrm{dm}, 15.3 \mathrm{~mm} w w, 14.3 \mathrm{~mm}$ wh; $\times 4.0$. H-J. Ontogenetic development of the conch width index (ww/dm), umbilical width index (uw/dm), whorl width index (ww/wh), and whorl expansion rate (WER) of all available specimens.

\section{Bollandoceras subangulare $\mathbf{n}$. sp.}

Figures 16, 17

Derivation of name. From Latin angulus, because of the subangular umbilical margin.

Holotype. Specimen MB.C.18683.1, illustrated in Figure 16A.

Type locality and horizon. Sebkha de Timimoun, locality TIM-B2 (10 km west-southwest of Timimoun, Algeria); lower part of the Lower Bollandoceras-Bollandites Assemblage.

Material. 31 specimens, conch diameter between 10 and $47 \mathrm{~mm}$. Furthermore, 12 specimens, which cannot be attributed with certainty to the new species.

Diagnosis. Bollandoceras with major ontogenetic changes of conch geometry: conch subinvolute to subevolute throughout ontogeny with a trend towards a decrease of the uw/dm ratio in the adult stage; conch becoming discontinuously more slender during ontogeny: thickly pachyconic in the early juvenile stage and discoidal above $25 \mathrm{~mm} \mathrm{dm}$ with a slight increase of the ww/dm ratio between $5 \mathrm{and} 15 \mathrm{~mm}$ dm; aperture low in juveniles and continuously becoming high during ontogeny; umbilical margin rounded in juveniles and subangular in the adult stage; umbilical wall flattened and oblique in the adult stage. Ornament with fine growth lines, course slightly biconvex with moderately deep ventral sinus; steinkern smooth except for rather strong constrictions. Suture line with narrow, slightly diverging external lobe with slightly sinuous flanks and very low median saddle; ventrolateral saddle broadly rounded and asymmetric; adventive lobe V-shaped, almost symmetric. 
Table 13. Conch ontogeny (Figs 17A-D, G-I) of Bollandoceras subangulare n. sp.

\begin{tabular}{|c|c|c|c|}
\hline $\mathrm{dm}$ & conch shape & whorl cross section shape & aperture \\
\hline $3 \mathrm{~mm}$ & $\begin{array}{l}\text { thickly discoidal to thinly pachyconic; subinvolute to } \\
\text { subevolute } \\
\text { (ww/dm }=0.55-0.65 ; u w / d m=0.25-0.40 \text { ) }\end{array}$ & $\begin{array}{l}\text { weakly to moderately depressed; strongly to } \\
\text { very strongly embracing } \\
\text { (ww/wh }=1.35-1.80 ; \text { IZR }=0.40-0.55 \text { ) }\end{array}$ & $\begin{array}{l}\text { low } \\
(\text { WER }=1.50-1.65)\end{array}$ \\
\hline $8 \mathrm{~mm}$ & $\begin{array}{l}\text { thickly discoidal to thinly pachyconic; subinvolute } \\
\text { (ww/dm }=0.55-0.65 ; \mathrm{ww} / \mathrm{dm}=0.20-0.30 \text { ) }\end{array}$ & $\begin{array}{l}\text { weakly to moderately depressed; strongly to } \\
\text { very strongly embracing } \\
\text { (ww/wh }=1.30-1.60 ; \mathrm{IZR}=0.40-0.50)\end{array}$ & $\begin{array}{l}\text { low to moderate } \\
(\text { WER }=1.55-1.80)\end{array}$ \\
\hline $20 \mathrm{~mm}$ & $\begin{array}{l}\text { thickly discoidal to thinly pachyconic; subinvolute } \\
\text { (ww/dm }=0.55-0.65 ; \mathrm{uw} / \mathrm{dm}=0.20-0.30 \text { ) }\end{array}$ & $\begin{array}{l}\text { weakly depressed; strongly embracing } \\
\text { (ww/wh }=1.30-1.50 ; \text { IZR }=0.40-0.45 \text { ) }\end{array}$ & $\begin{array}{l}\text { moderate } \\
(\mathrm{WER}=1.85-1.95)\end{array}$ \\
\hline $40 \mathrm{~mm}$ & $\begin{array}{l}\text { thickly discoidal; subinvolute } \\
\text { (ww/dm } \sim 0.50 ; \text { uw/dm } \sim 0.15 \text { ) }\end{array}$ & $\begin{array}{l}\text { weakly depressed; strongly embracing } \\
\text { (ww/wh } \sim 1.00 ; \text { IZR } \sim 0.40 \text { ) }\end{array}$ & $\begin{array}{l}\text { high } \\
\text { (WER 2.05) }\end{array}$ \\
\hline
\end{tabular}

Table 14. Conch dimensions (in $\mathrm{mm}$ ) and proportions for reference specimens of Bollandoceras subangulare $\mathrm{n}$. sp.

\begin{tabular}{lcccccccccc}
\hline & dm & ww & wh & uw & ah & ww/dm & ww/wh & uw/dm & WER & IZR \\
\hline paratype MB.C.18683.10 & 31.2 & 16.6 & 14.0 & 5.7 & 8.6 & 0.53 & 1.19 & 0.18 & 1.91 & 0.39 \\
holotype MB.C.18683.1 & 28.5 & 15.1 & 14.0 & 7.0 & 7.9 & 0.53 & 1.08 & 0.25 & 1.91 & 0.44 \\
paratype MB.C.18683.3 & 19.4 & 11.8 & 8.2 & 5.1 & 4.4 & 0.61 & 1.44 & 0.26 & 1.68 & 0.46 \\
paratype MB.C.18683.2 & 17.7 & 10.7 & 8.0 & 4.1 & 4.3 & 0.61 & 1.34 & 0.23 & 1.75 & 0.46 \\
paratype MB.C.18683.4 & 17.3 & 10.9 & 7.1 & 5.4 & 4.3 & 0.63 & 1.52 & 0.31 & 1.77 & 0.40 \\
\hline
\end{tabular}

Table 15. Suture line proportions (Figs 17E, F) for Bollandoceras subangulare n. sp.

\begin{tabular}{llllllll}
\hline specimen & at dm & EL w/d & EL/VLS & EL/AL & MS h & VLS w/h & remarks \\
\hline paratype MB.C.18683.10 & $20.0 \mathrm{~mm}$ & 0.55 & 0.64 & 0.86 & 0.16 & 0.85 & \\
paratype MB.C.18683.9 & $8.0 \mathrm{~mm}$ & 0.50 & 0.62 & 0.68 & 0.13 & 0.82 & A lobe rather wide \\
\hline
\end{tabular}

Discussion. Bollandoceras subangulare belongs together with the other species of the genus, which possess a rather wide umbilicus in the adult stage. It differs from the co-occurring $B$. nitens mainly in the wider umbilicus (uw/dm $=0.20-0.25$ at $20 \mathrm{~mm} \mathrm{dm}$ in B. subangulare and only $0.10-0.15$ in B. nitens). Furthermore, B. subangulare has rather strong steinkern constrictions, which separates it from $B$. nitens.

Some of the species, such as B. hagaraswad and B. hagarkarim from horizon C8 have a similarly wide umbilicus in large specimens, but differ from $B$. subangulare in their much longer evolute juvenile stage.

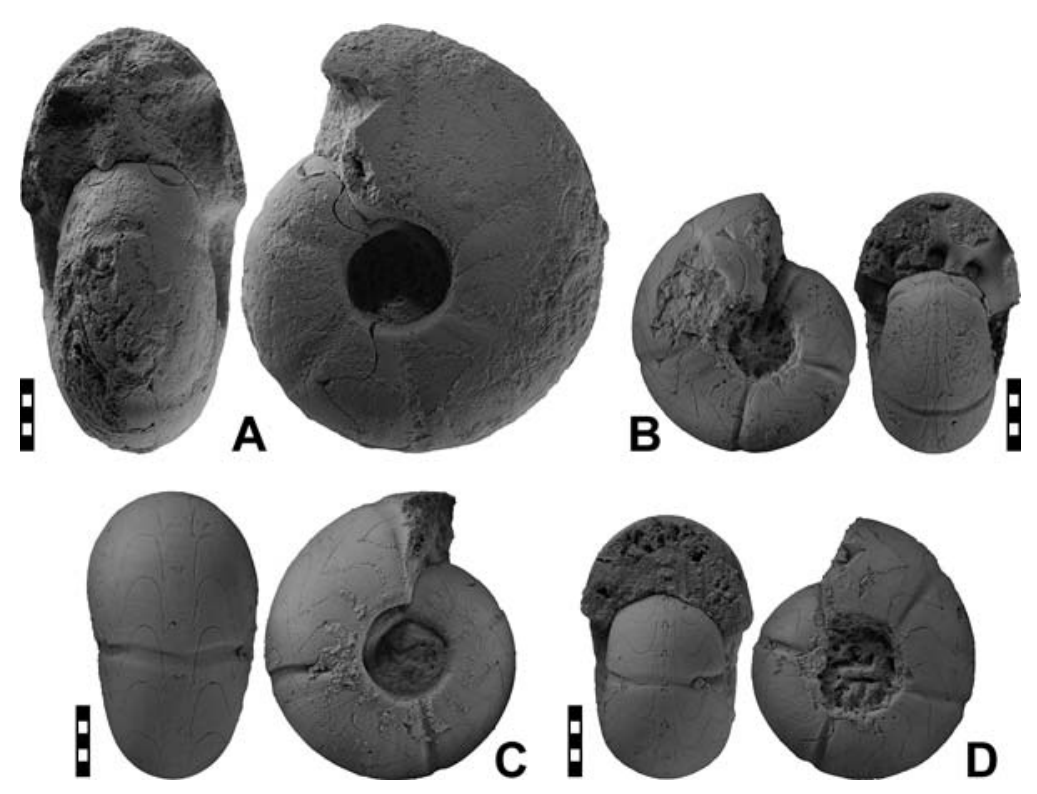

museum-fossilrecord.wiley-vch.de
Figure 16. Bollandoceras subangulare n. sp. from locality TIM-B2; all $\times 1.5$. A. Holotype MB.C.18683.1. B. Paratype MB.C.18683.2. C. Paratype MB.C.18683.3. D. Paratype MB.C.18683.4. 

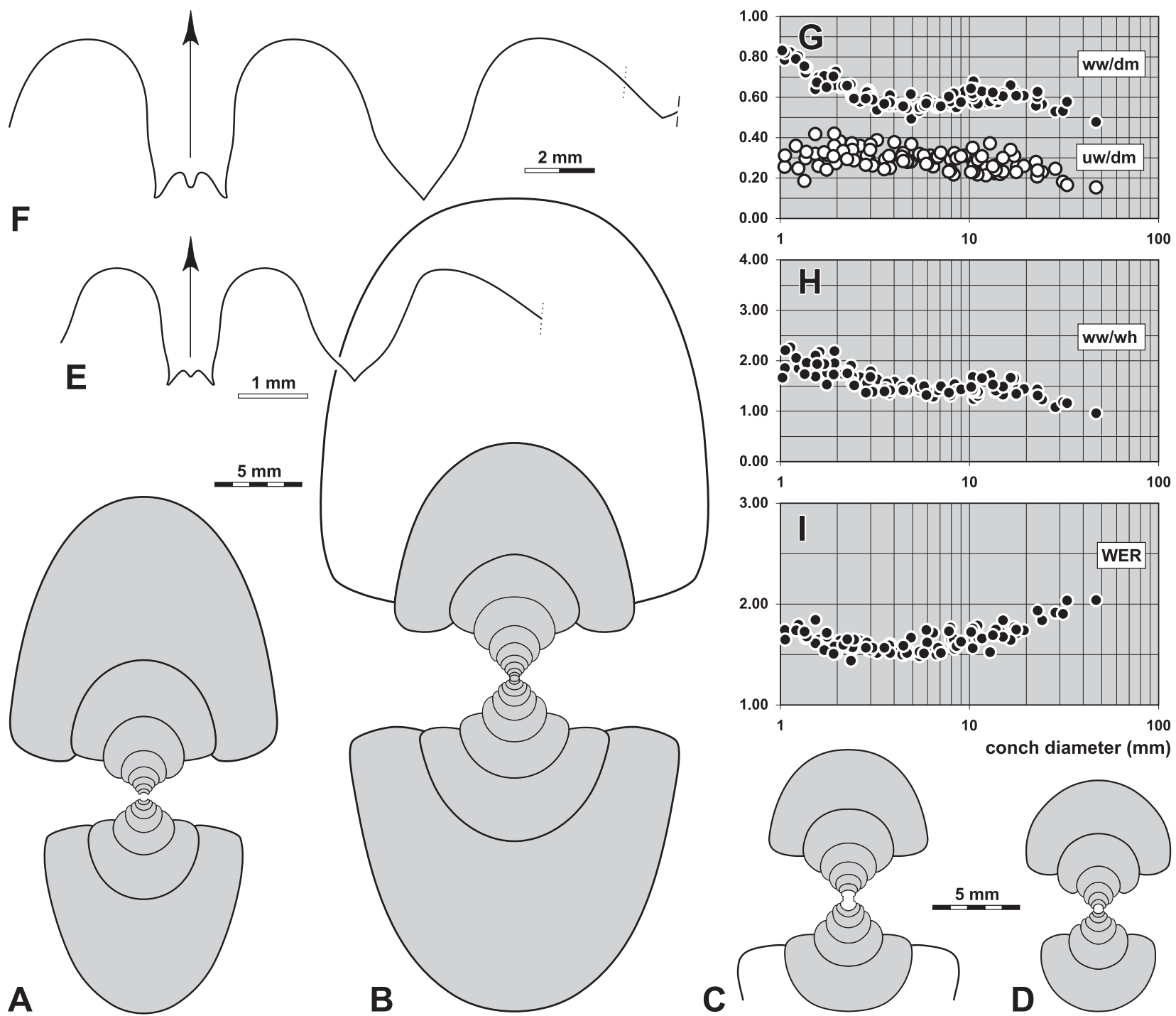

Figure 17. Bollandoceras subangulare n. sp. from locality TIM-B2. A. Cross section of paratype MB.C.18683.5; $\times 2.5$. B. Cross section of paratype MB.C.18683.6; $\times 2.5$. C. Cross section of paratype MB.C.18683.7; $\times 2.5$. D. Cross section of paratype MB.C.18683.8; $\times 2.5$. E. Suture line of paratype MB.C.18683.9, at $8.0 \mathrm{~mm} \mathrm{dm}, 4.7 \mathrm{~mm} w w, 3.3 \mathrm{~mm}$ wh; $\times 6.0$. F. Suture line of paratype MB.C.18683.10, at $19.8 \mathrm{~mm} \mathrm{dm}, 13.8 \mathrm{~mm}$ ww, $9.0 \mathrm{~mm}$ wh; $\times 4.0$. G-I. Ontogenetic development of the conch width index (ww/dm), umbilical width index (uw/dm), whorl width index (ww/wh), and whorl expansion rate (WER) of all available specimens.

\section{Bollandoceras politum n. sp.}

Figures 18, 19

Derivation of name. From Latin politus $=$ smoothed, because of the ornament.

Holotype. Specimen MB.C.18686.1, illustrated in Figure 18A.

Type locality and horizon. Sebkha de Timimoun, locality TIM-B3 (10 km west-southwest of Timimoun, Algeria); upper part of the Lower Bollandoceras-Bollandites Assemblage.

Material. 12 specimens, conch diameter between 20 and $50 \mathrm{~mm}$

Diagnosis. Bollandoceras with minor ontogenetic changes of conch geometry: conch subevolute in early juveniles and involute in the adult stage; conch becoming discontinuously more slender during ontogeny: thinly pachyconic in the early juvenile stage and discoidal at $45 \mathrm{~mm} \mathrm{dm}$, stable ww/dm ratio between 4 and $16 \mathrm{~mm} \mathrm{dm}$; aperture low in juveniles and moderately high to high above $10 \mathrm{~mm} \mathrm{dm}$; umbilical margin narrowly rounded in the adult stage. Steinkern smooth except for shallow, slightly biconvex constrictions with moderately deep ventral sinus in small stages; constrictions in the adult stage restricted to outer flanks and venter. Suture line with narrow, slightly diverging external lobe with moderately sinuous flanks and very low median saddle; ventrolateral saddle broadly rounded; adventive lobe broadly V-shaped, nearly symmetric. 
Table 16. Conch ontogeny (Figs 19A-D, F-H) of Bollandoceras politum n. sp.

\begin{tabular}{lllll}
\hline $\mathrm{dm}$ & conch shape & whorl cross section shape & aperture \\
\hline $3 \mathrm{~mm}$ & thickly discoidal to thinly pachyconic; subinvolute & weakly depressed; very strongly embracing & low \\
& $($ ww/dm $=0.55-0.65 ;$ uw/dm $=0.25-0.30)$ & $($ ww/wh $=1.30-1.40 ;$ IZR $=0.45-0.55)$ & $($ WER $=1.60-1.70)$ \\
$8 \mathrm{~mm}$ & thickly discoidal; involute to subinvolute & weakly depressed; very strongly embracing & moderate \\
& $($ ww/dm $=0.55-0.60 ;$ uw/dm $=0.10-0.20)$ & $($ ww/wh $=1.10-1.30 ;$ IZR $=0.45-0.50)$ & $($ WER $=1.75-2.00)$ \\
$20 \mathrm{~mm}$ & thickly discoidal to thinly pachyconic; involute & weakly depressed; strongly embracing & moderate to high \\
& $($ ww/dm $=0.55-0.65 ;$ uw/dm $=0.08-0.15)$ & $($ ww/wh $=1.00-1.25 ;$ IZR $=0.40-0.45)$ & $($ WER $=1.90-2.15)$ \\
$45 \mathrm{~mm}$ & thickly discoidal; involute & weakly compressed; strongly embracing & high \\
& $($ ww/dm $\sim 0.50 ;$ uw/dm $\sim 0.10)$ & $($ ww/wh $\sim 0.90 ;$ IZR $\sim 0.45)$ & (WER 2.10)
\end{tabular}
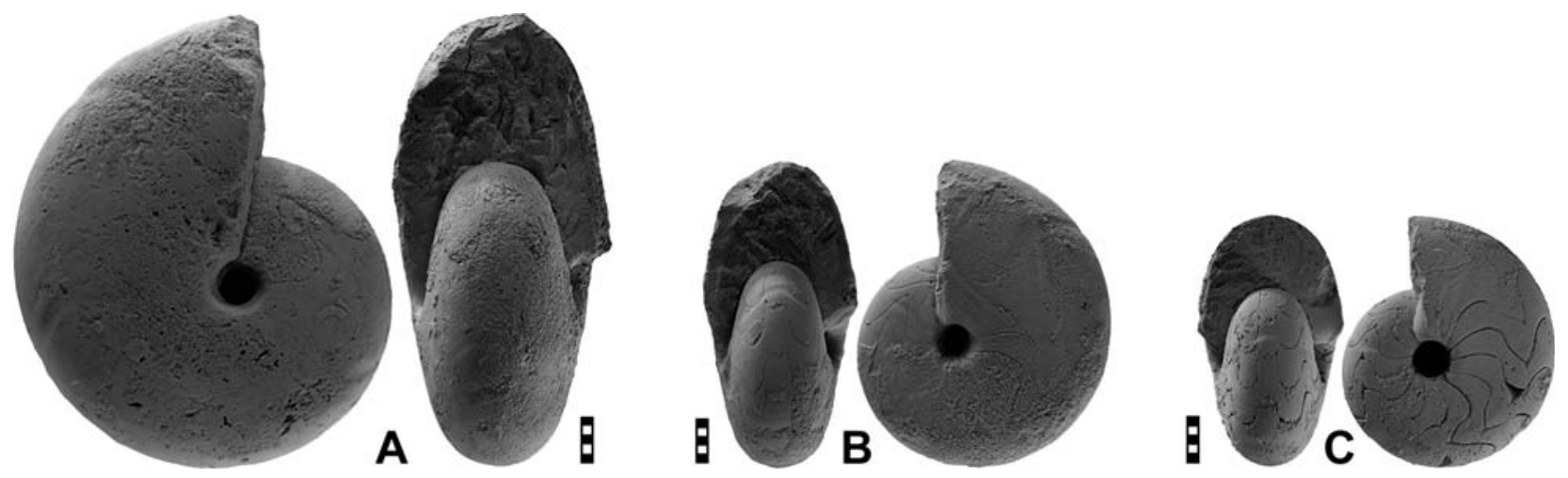

Figure 18. Bollandoceras politum n. sp. from locality TIM-B3; all ×1.0. A. Holotype MB.C.18686.1. B. Paratype MB.C.18686.2. C. Paratype MB.C.18686.3.
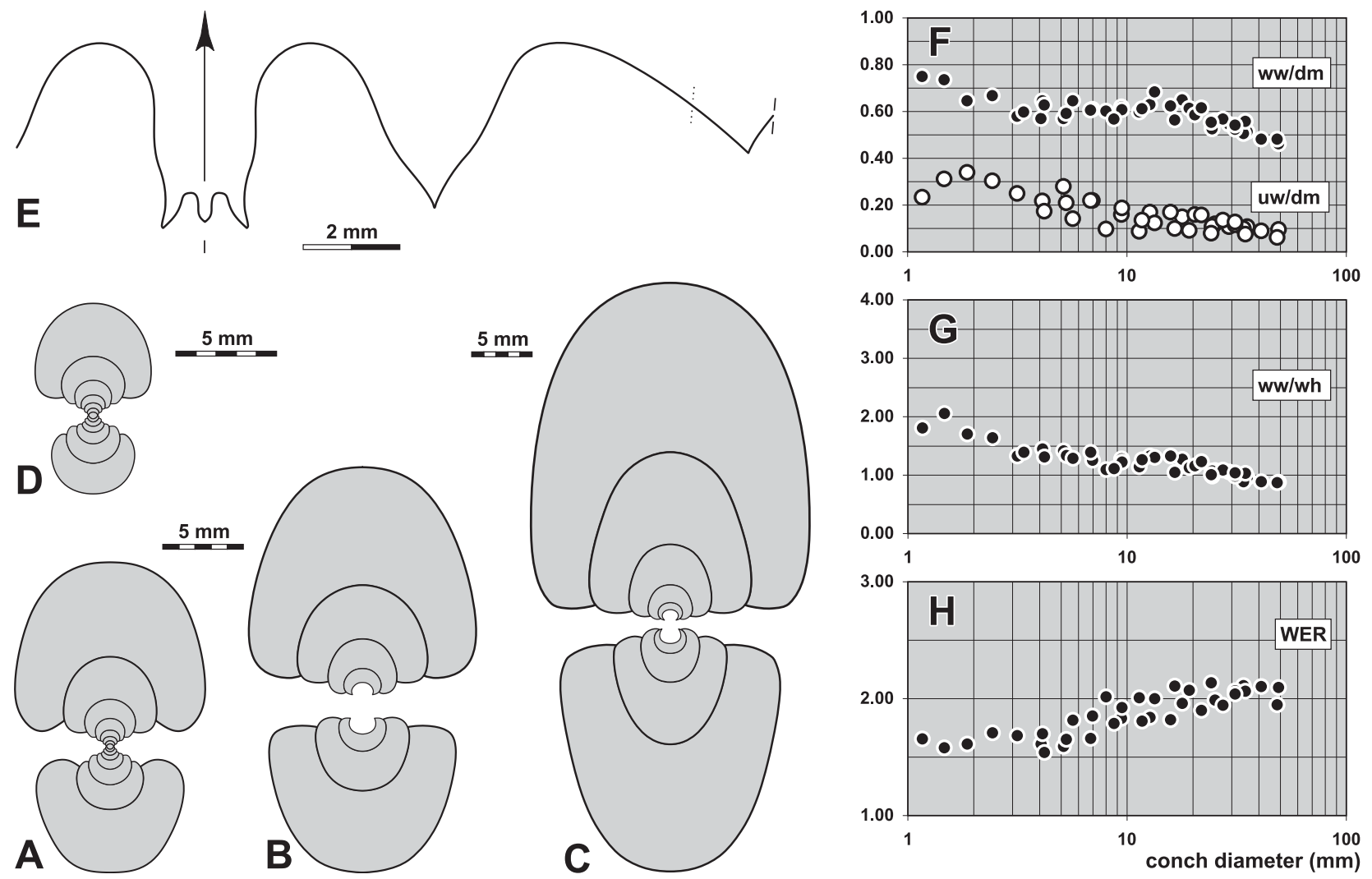

Figure 19. Bollandoceras politum n. sp. from locality TIM-B3. A. Cross section of paratype MB.C.18686.4; $\times 2.0$. B. Cross section of paratype MB.C.18686.5; $\times 2.0$. C. Cross section of paratype MB.C.18686.6; $\times 1.5$. D. Cross section (inner whorls) of paratype MB.C.18686.4; $\times 2.5$. E. Suture line of paratype MB.C.18686.7, at $8.6 \mathrm{~mm} w w, 8.5 \mathrm{~mm} w \mathrm{wh} \times 6.0$. F-H. Ontogenetic development of the conch width index (ww/dm), umbilical width index (uw/dm), whorl width index (ww/wh), and whorl expansion rate (WER) of all available specimens. 
Table 17. Conch dimensions (in $\mathrm{mm}$ ) and proportions for reference specimens of Bollandoceras politum n. sp.

\begin{tabular}{|c|c|c|c|c|c|c|c|c|c|c|}
\hline & $\mathrm{dm}$ & ww & wh & uw & ah & $w w / d m$ & ww/wh & $\mathrm{uw} / \mathrm{dm}$ & WER & IZR \\
\hline holotype MB.C.18686.1 & 49.0 & 22.6 & 25.8 & 4.7 & 15.1 & 0.46 & 0.88 & 0.10 & 2.10 & 0.41 \\
\hline paratype MB.C.18686.8 & 40.9 & 19.7 & 22.2 & 3.7 & 12.7 & 0.48 & 0.89 & 0.09 & 2.10 & 0.43 \\
\hline paratype MB.C.18686.2 & 34.0 & 17.2 & 19.4 & 3.4 & 10.6 & 0.51 & 0.89 & 0.10 & 2.11 & 0.45 \\
\hline paratype MB.C.18686.7 & 31.1 & 16.3 & 16.5 & 3.6 & 9.5 & 0.52 & 0.98 & 0.12 & 2.07 & 0.43 \\
\hline paratype MB.C.18686.3 & 27.4 & 15.6 & 14.3 & 3.7 & 7.7 & 0.57 & 1.09 & 0.14 & 1.95 & 0.46 \\
\hline
\end{tabular}

Table 18. Suture line proportions (Fig. 19E) for Bollandoceras politum n. sp.

\begin{tabular}{lllllll}
\hline specimen & at dm & EL w/d & EL/vLS & EL/AL & MS h \\
\hline paratype MB.C.18686.7 & $14.0 \mathrm{~mm}$ & 0.55 & 0.78 & 0.98 & 0.19 \\
\hline
\end{tabular}

Discussion. Bollandoceras politum has the most slender conch shape and the narrowest umbilicus out of all the species from assemblage TIM-B3. At about $40 \mathrm{~mm}$ conch diameter, B. politum has a ww/dm ratio of 0.50 and a uw/dm ratio of 0.10 , whereas $B$. aridum is stouter $(\mathrm{ww} / \mathrm{dm}=0.60)$ and more widely umbilicate (uw/ $\mathrm{dm}=0.15)$.

B. nitens from assemblage TIM-B2 has a similar conch shape, but differs from $B$. politum in the narrower umbilicate inner whorls and the narrower external lobe (EL w/d $=0.45$ in B. nitens and 0.55 in B. politum).

Specimens from the Tien Shan described by Popov $(1965,1968)$ and there attributed to Bollandites are similar to the Algerian material, but most of them (B. bashatchensis, B. narynensis, and B. shabyrensis) show an external lobe that has almost parallel flanks and are thus closer to Dzhaprakoceras. B. kokdzharensis shows an external lobe with diverging flanks, but the first species differs from B. politum in the rursiradiate constriction.

\section{Bollandoceras aridum n. sp.}

Figures 20, 21

Derivation of name. From Latin aridum = dry, referring to the Sebkha de Timimoun.

Holotype. Specimen MB.C.18687.1, illustrated in Figure 20.

Type locality and horizon. Sebkha de Timimoun, locality TIM-B3 (10 km west-southwest of Timimoun, Algeria); upper part of the Lower Bollandoceras-Bollandites Assemblage.

Material. Eight specimens, conch diameter between 29 and $56 \mathrm{~mm}$.

Diagnosis. Bollandoceras with major ontogenetic changes of conch geometry: conch subevolute in juveniles up to $8 \mathrm{~mm} \mathrm{dm}$ and then continuously becoming involute in the adult stage; conch becoming discontinuously more slender during ontogeny: thinly pachyconic in the early juvenile stage and discoidal at $45 \mathrm{~mm} \mathrm{dm}$, increasing ww/dm ratio between 4 and $18 \mathrm{~mm}$ dm; aperture very low or low in juveniles and moderately high to high above $20 \mathrm{~mm}$ dm; umbilical margin rounded in juveniles and more pronounced in the adult stage. Ornament with very fine growth lines, course almost linear across the flanks and a shallow, rounded sinus on the venter; steinkern smooth except for very shallow, slightly biconvex constrictions. Suture line with narrow, slightly diverging external lobe with sinuous flanks, and low median saddle; ventrolateral saddle broadly rounded; adventive lobe V-shaped, symmetric.

Table 19. Conch ontogeny (Figs $21 \mathrm{~A}-\mathrm{C}, \mathrm{E}-\mathrm{G})$ of Bollandoceras aridum n. sp.

\begin{tabular}{|c|c|c|c|}
\hline $\mathrm{dm}$ & conch shape & whorl cross section shape & aperture \\
\hline $3 \mathrm{~mm}$ & $\begin{array}{l}\text { thickly discoidal; subevolute } \\
(w w / d m=0.50-0.55 ; u w / d m=0.30-0.40)\end{array}$ & $\begin{array}{l}\text { weakly to moderately depressed; } \\
\text { very strongly embracing } \\
\text { (ww/wh }=1.35-1.60 ; \text { IZR }=0.45-0.55 \text { ) }\end{array}$ & $\begin{array}{l}\text { very low to low } \\
(\text { WER }=1.45-1.55)\end{array}$ \\
\hline $8 \mathrm{~mm}$ & $\begin{array}{l}\text { thickly discoidal; subevolute } \\
(w w / d m=0.50-0.60 ; u w / d m=0.30-0.40)\end{array}$ & $\begin{array}{l}\text { weakly depressed; very strongly embracing } \\
(\text { ww/wh }=1.40-1.50 ; \text { IZR }=0.45-0.50)\end{array}$ & $\begin{array}{l}\text { low } \\
(\text { WER }=1.50-1.60)\end{array}$ \\
\hline $20 \mathrm{~mm}$ & $\begin{array}{l}\text { thickly discoidal to thinly pachyconic; subinvolute } \\
\text { (ww/dm }=0.55-0.70 ; \mathrm{uw} / \mathrm{dm}=0.15-0.25 \text { ) }\end{array}$ & $\begin{array}{l}\text { weakly depressed; very strongly embracing } \\
(\text { ww/wh }=1.15-1.45 ; \mathrm{IZR}=0.45-0.50)\end{array}$ & $\begin{array}{l}\text { moderate } \\
(\mathrm{WER}=1.80-2.00)\end{array}$ \\
\hline $45 \mathrm{~mm}$ & $\begin{array}{l}\text { thinly to thickly discoidal; involute } \\
\text { (ww/dm }=0.45-0.55 ; u w / d m=0.08-0.15 \text { ) }\end{array}$ & $\begin{array}{l}\text { weakly compressed to weakly depressed; } \\
\text { very strongly embracing } \\
\text { (ww/wh }=0.90-1.10 ; \text { IZR }=0.45-0.50 \text { ) }\end{array}$ & $\begin{array}{l}\text { high } \\
(\text { WER }=2.00-2.10)\end{array}$ \\
\hline
\end{tabular}


Table 20. Conch dimensions (in $\mathrm{mm}$ ) and proportions for reference specimens of Bollandoceras aridum $\mathrm{n}$. $\mathrm{sp}$.

\begin{tabular}{lcccccccccc}
\hline & $\mathrm{dm}$ & ww & wh & uw & ah & ww/dm & ww/wh & uw/dm & WER & IZR \\
\hline paratype MB.C.18687.4 & 37.9 & 23.5 & 18.3 & 6.5 & 10.5 & 0.62 & 1.28 & 0.17 & 1.91 & 0.43 \\
holotype MB.C.18687.1 & 36.2 & 21.3 & 18.5 & 6.2 & 11.1 & 0.59 & 1.15 & 0.17 & 2.08 & 0.40 \\
paratype MB.C.18687.6 & 29.2 & 17.0 & 15.6 & 5.1 & 8.7 & 0.58 & 1.09 & 0.17 & 2.03 & 0.44 \\
paratype MB.C.18687.5 & 28.9 & 17.7 & 15.3 & 4.3 & 8.1 & 0.61 & 1.16 & 0.15 & 1.93 & 0.47 \\
\hline
\end{tabular}

Table 21. Suture line proportions (Fig. 21D) for Bollandoceras aridum n. sp.

\begin{tabular}{llllllll}
\hline & at $\mathrm{dm}$ & EL w/d & EL/NLS & EL/AL & MS h & VLS w/h & remarks \\
\hline holotype MB.C.18687.1 & $35.0 \mathrm{~mm}$ & 0.66 & 0.85 & 1.14 & 0.23 & 0.78 & A lobe barely pouched \\
\hline
\end{tabular}

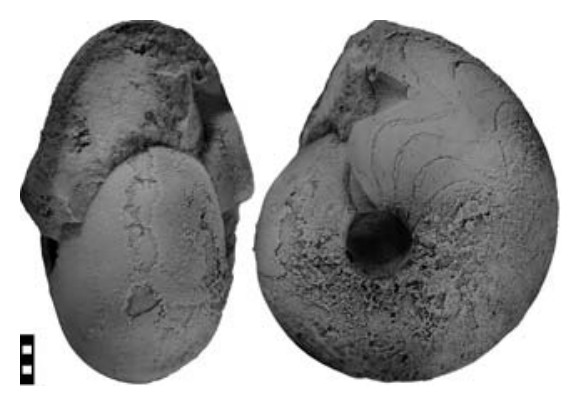

Figure 20. Bollandoceras aridum n. sp. from locality TIM-B3; holotype MB.C. $18687.1 ; \times 1.0$.
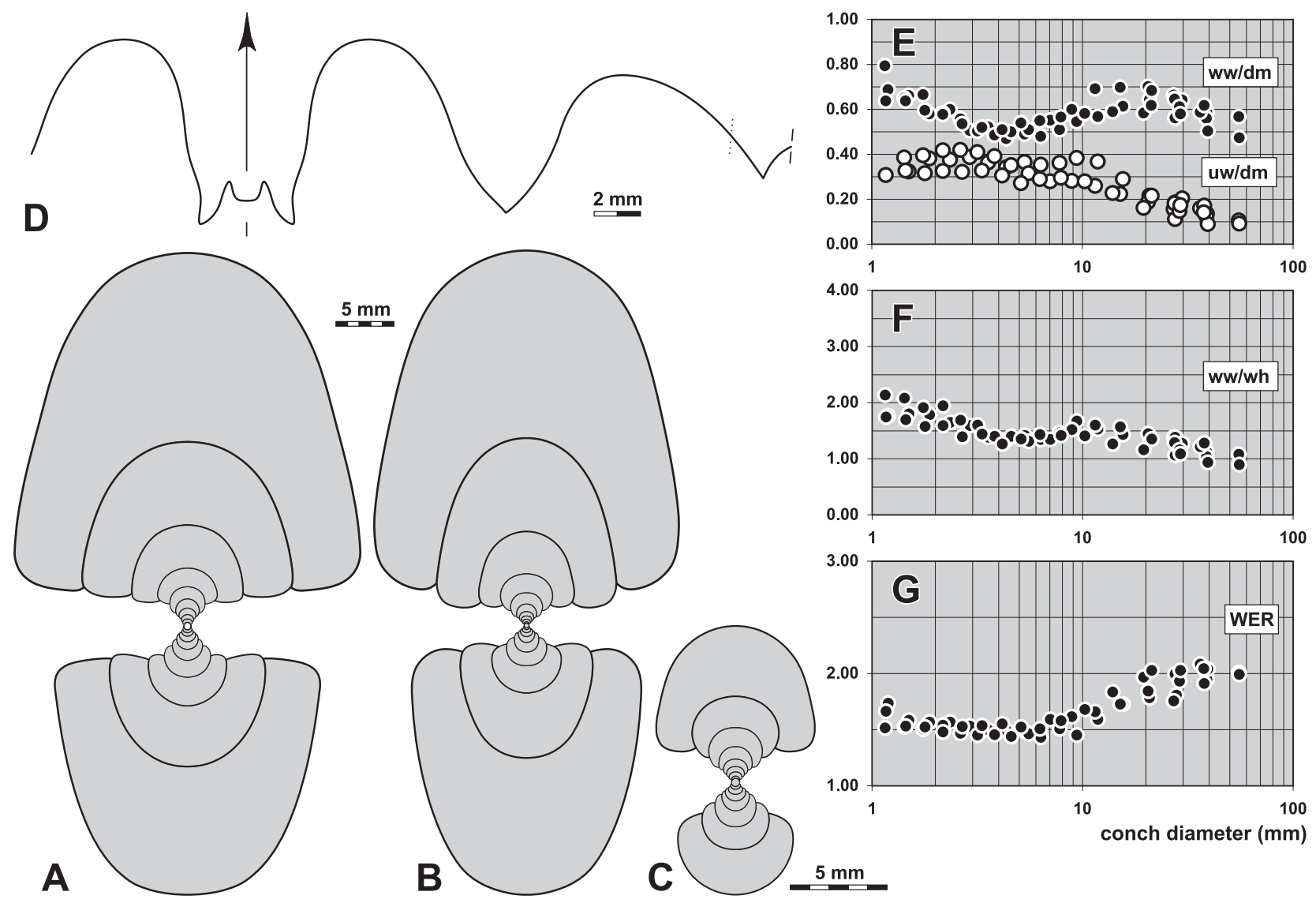

Figure 21. Bollandoceras aridum n. sp. from locality TIM-B3. A. Cross section of paratype MB.C.18687.2; $\times 1.5$. B. Cross section of paratype MB.C.18687.3; $\times 1.5$. C. Cross section of the inner whorls of the same specimen; $\times 2.5$. D. Suture line of holotype MB.C.18687.1, at $35.0 \mathrm{~mm} \mathrm{dm}, 22.5 \mathrm{~mm}$ ww, $17.5 \mathrm{~mm}$ wh; $\times 3.0$. E-G. Ontogenetic development of the conch width index (ww/ $\mathrm{dm})$, umbilical width index (uw/dm), whorl width index (ww/wh), and whorl expansion rate (WER) of all available specimens. 
Discussion. The co-occurring species B. politum has a laterally more compressed and narrower umbilicate conch (see discussion under this species). The species described by Popov $(1965,1968)$ from the Tien Shan differ in the external lobe with almost parallel-sided flanks and the narrower conch. B. subangulare has a wider umbilicus in the adult stage. The species of Bollandoceras from horizon TIM-C8 (B. zuhara, B. mirrih) show a wider umbilicate juvenile stage.

\section{Bollandoceras zuhara n. sp.}

Figures 22, 23

Derivation of name. From the Arabic zuhara $=$ Venus.

Holotype. Specimen MB.C.18691.1, illustrated in Figure 22A.

Type locality and horizon. Sebkha de Timimoun, locality TIM-C8 (13.3 km west of Timimoun, Algeria); Upper Bollandoceras-Bollandites Assemblage.

Material. 108 specimens, conch diameter between 8 and $30 \mathrm{~mm}$.

Diagnosis. Bollandoceras with major ontogenetic changes of conch geometry: conch evolute in the early juvenile stage (2-3 mm dm) and then rapidly becoming involute at $20 \mathrm{~mm} \mathrm{dm}$; conch thickly discoidal in the early juvenile stage, thickly discoidal to thinly pachyconic in the intermediate stage $(4-10 \mathrm{~mm} \mathrm{dm})$ and thinly discoidal at $30 \mathrm{~mm} \mathrm{dm}$; aperture very low in juveniles and then rapidly increasing (being high at $20 \mathrm{~mm} \mathrm{dm}$ ); umbilical margin broadly or narrowly rounded in all stages. Steinkern smooth except for shallow, biconvex constrictions and traces of biconvex growth lines. Suture line with narrow, slightly diverging external lobe with strongly sinuous flanks and very low median saddle; ventrolateral saddle broadly rounded; small adventive lobe V-shaped, symmetric.

Table 22. Conch ontogeny (Figs $23 \mathrm{~A}-\mathrm{E}, \mathrm{H}-\mathrm{J}$ ) of Bollandoceras zuhara n. sp.

\begin{tabular}{|c|c|c|c|}
\hline $\mathrm{dm}$ & conch shape & whorl cross section shape & aperture \\
\hline $2 \mathrm{~mm}$ & $\begin{array}{l}\text { thickly discoidal; evolute } \\
\text { (ww/dm }=0.50-0.58 ; u w / d m=0.45-0.55)\end{array}$ & $\begin{array}{l}\text { moderately depressed; strongly embracing } \\
(\mathrm{ww} / \mathrm{wh}=1.65-2.00 ; \mathrm{IZR}=0.40-0.45)\end{array}$ & $\begin{array}{l}\text { very low to low } \\
(\mathrm{WER}=1.40-1.55)\end{array}$ \\
\hline $8 \mathrm{~mm}$ & $\begin{array}{l}\text { thickly discoidal to thinly pachyconic; subinvolute } \\
\text { (ww/dm }=0.55-0.70 \mathrm{uw} / \mathrm{dm}=0.22-0.30 \text { ) }\end{array}$ & $\begin{array}{l}\text { weakly depressed; strongly embracing } \\
(\mathrm{ww} / \mathrm{wh}=1.15-1.40 ; \mathrm{IZR}=0.40-0.45)\end{array}$ & $\begin{array}{l}\text { moderate } \\
(\mathrm{WER}=1.70-1.90)\end{array}$ \\
\hline $20 \mathrm{~mm}$ & $\begin{array}{l}\text { thinly to thickly discoidal; involute } \\
\text { (ww/dm }=0.45-0.55 ; \mathrm{uw} / \mathrm{dm}=0.08-0.15 \text { ) }\end{array}$ & $\begin{array}{l}\text { weakly compressed to weakly depressed; strongly } \\
\text { embracing (ww/wh }=0.85-1.25 ; \mathrm{IZR}=0.40-0.45 \text { ) }\end{array}$ & $\begin{array}{l}\text { high } \\
(\text { WER }=2.00-2.15)\end{array}$ \\
\hline
\end{tabular}

Table 23. Conch dimensions (in $\mathrm{mm}$ ) and proportions for reference specimens of Bollandoceras zuhara $\mathrm{n}$. sp.

\begin{tabular}{|c|c|c|c|c|c|c|c|c|c|c|}
\hline & $\mathrm{dm}$ & ww & wh & uw & ah & $w w / d m$ & ww/wh & $\mathrm{uw} / \mathrm{dm}$ & WER & IZR \\
\hline holotype MB.C.18691.1 & 30.5 & 13.8 & 16.3 & 2.5 & 9.4 & 0.45 & 0.85 & 0.08 & 2.09 & 0.42 \\
\hline paratype MB.C.18691.2 & 21.6 & 11.3 & 12.2 & 1.7 & 6.5 & 0.52 & 0.93 & 0.08 & 2.05 & 0.47 \\
\hline paratype MB.C.18691.12 & 16.6 & 8.5 & 8.9 & 1.7 & 4.9 & 0.51 & 0.95 & 0.10 & 2.02 & 0.45 \\
\hline paratype MB.C.18691.3 & 12.8 & 7.1 & 6.6 & 2.5 & 3.8 & 0.55 & 1.08 & 0.20 & 2.04 & 0.42 \\
\hline paratype MB.C.18691.13 & 11.0 & 5.5 & 4.7 & 2.6 & 2.9 & 0.50 & 1.17 & 0.24 & 1.84 & 0.39 \\
\hline paratype MB.C.18691.4 & 10.1 & 5.5 & 4.9 & 1.9 & 3.0 & 0.54 & 1.12 & 0.19 & 2.02 & 0.39 \\
\hline
\end{tabular}

Table 24. Suture line proportions (Figs 23F, G) for Bollandoceras zuhara n. sp.

\begin{tabular}{llllllll}
\hline specimen & at dm & EL w/d & EL/VLS & EL/AL & MS h & VLS w/h remarks \\
\hline paratype MB.C.18691.11 & $29.0 \mathrm{~mm}$ & 0.62 & 0.89 & 1.06 & 0.17 & 0.69 & prongs of the E lobe very narrow \\
paratype MB.C.18691.10 & $11.8 \mathrm{~mm}$ & 0.77 & 1.09 & 1.22 & 0.18 & 0.70 & E lobe moderately wide \\
\hline
\end{tabular}

Discussion. Bollandoceras zuhara is the most involute Bollandoceras species from assemblage TIM-C8. It differs from all other co-occurring species in the shorter evolute growth interval (ending at about $3 \mathrm{~mm}$ conch diameter). B. mirrih is the most similar in terms of morphology; in this species the evolute juvenile growth interval ends at $4 \mathrm{~mm} \mathrm{dm}$; larger specimens possess always a wider umbilicus than B. zuhara.

B. zuhara differs from the species of the genus that occur in the stratigraphically lower assemblages TIM-B2 and TIM-B3 in the wider umbilicate inner whorls (uw/dm $=0.40-0.50$ at $2-3 \mathrm{~mm} \mathrm{dm}$ ). The uw/dm ratios of the species B. nitens, B. subangulare, B. politum, and B. aridum ranges, at this diameter, between 0.25 and 0.35 .

This new species shows closer resemblance with the stratigraphically younger representatives of the genus, such as the type species B. micronotum (Phillips, 1836). This species, however, has a higher median saddle and an adult conch with a subangular ventrolateral margin separating the flanks from the slightly flattened venter. 

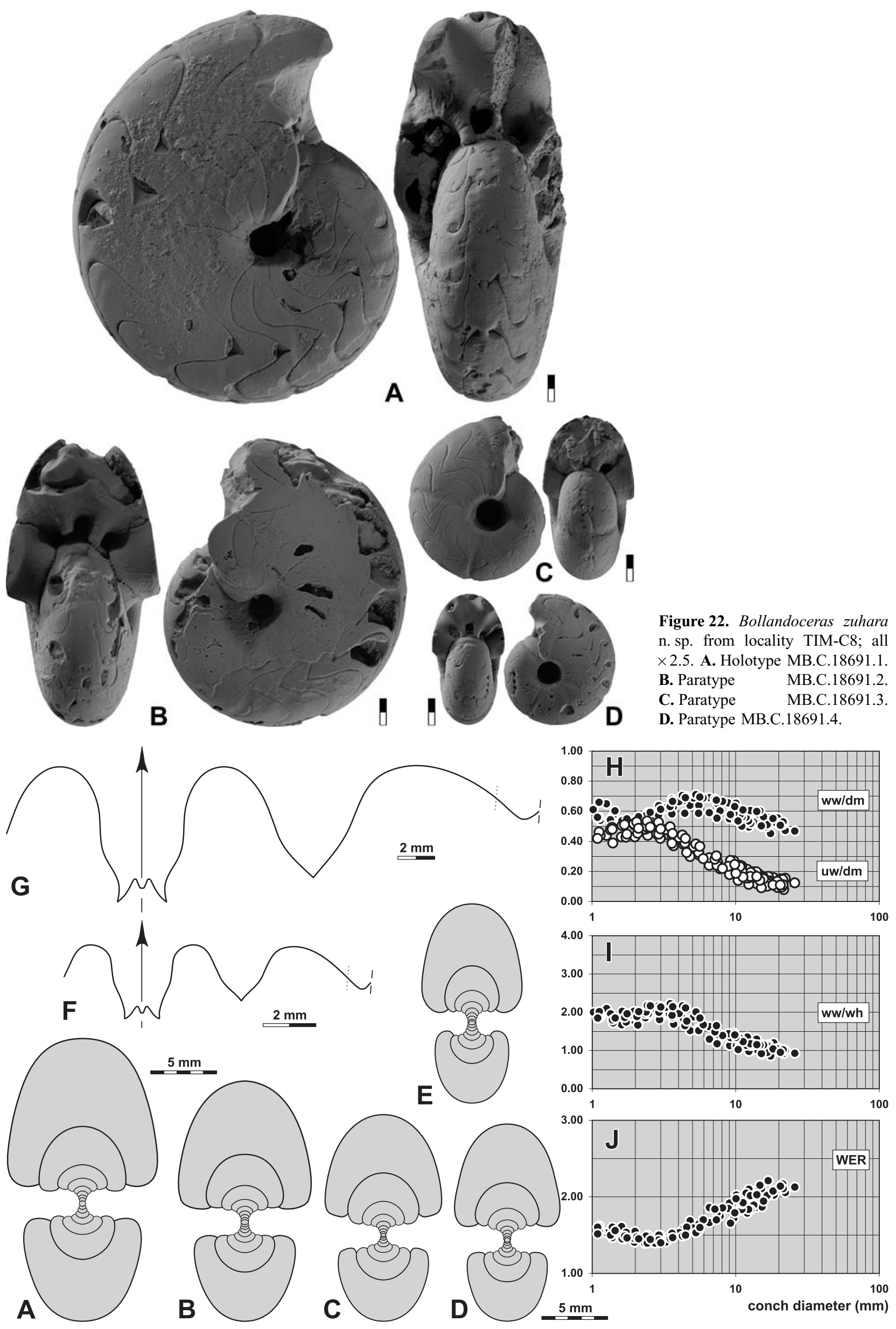


\section{Bollandoceras mirrih $\mathbf{n}$. sp.}

Figures 24, 25

Derivation of name. From the Arabic mirrih = Mars.

Holotype. Specimen MB.C.18692.1, illustrated in Figure 24A.

Type locality and horizon. Sebkha de Timimoun, locality TIM-C8 (13.3 km west of Timimoun, Algeria); Upper Bollandoceras-Bollandites Assemblage.

Material. 119 specimens, conch diameter between 8 and $25 \mathrm{~mm}$.

Diagnosis. Bollandoceras with major ontogenetic changes of the conch geometry: conch evolute in the early juvenile stage (1.5-3 mm dm) and then rapidly becoming involute or subinvolute at $20 \mathrm{~mm} \mathrm{dm}$; conch thickly discoidal in the early juvenile stage, thinly to thickly pachyconic in the intermediate stage $(4-10 \mathrm{~mm} \mathrm{dm})$ and again thickly discoidal at $20 \mathrm{~mm} \mathrm{dm}$; aperture very low in juveniles and then rapidly increasing (moderately high to high at $20 \mathrm{~mm} \mathrm{dm}$ ); umbilical margin rounded in juveniles and subangular in the adult stage. Steinkern smooth except for shallow, slightly biconvex constrictions and traces of biconvex growth lines. Suture line with narrow, slightly diverging external lobe with strongly sinuous flanks and low median saddle; ventrolateral saddle broadly rounded; small adventive lobe V-shaped, symmetric.

Table 25. Conch ontogeny (Figs 25A-C, G-J) of Bollandoceras mirrih n. sp.

\begin{tabular}{|c|c|c|c|}
\hline $\mathrm{dm}$ & conch shape & whorl cross section shape & aperture \\
\hline $2 \mathrm{~mm}$ & $\begin{array}{l}\text { thickly discoidal; evolute } \\
(\mathrm{ww} / \mathrm{dm}=0.50-0.60 ; \mathrm{uw} / \mathrm{dm}=0.50-0.55)\end{array}$ & $\begin{array}{l}\text { moderately to strongly depressed; strongly } \\
\text { embracing ( } w w / w h=1.80-2.20 ; \mid Z R=0.30-0.40 \text { ) }\end{array}$ & $\begin{array}{l}\text { very low } \\
(\mathrm{WER}=1.40-1.50)\end{array}$ \\
\hline $8 \mathrm{~mm}$ & $\begin{array}{l}\text { thinly to thickly pachyconic; subinvolute to subevolute } \\
\text { (ww/dm }=0.65-0.75 ; \mathrm{uw} / \mathrm{dm}=0.25-0.35 \text { ) }\end{array}$ & $\begin{array}{l}\text { moderately depressed; strongly embracing } \\
(\mathrm{ww} / \mathrm{wh}=1.50-2.00 ; \mathrm{IZR}=0.35-0.45)\end{array}$ & $\begin{array}{l}\text { low to moderate } \\
(\mathrm{WER}=1.60-1.85)\end{array}$ \\
\hline $20 \mathrm{~mm}$ & $\begin{array}{l}\text { thinly to thickly discoidal; involute to subinvolute } \\
\text { (ww/dm }=0.45-0.60 ; u w / d m=0.08-0.20)\end{array}$ & $\begin{array}{l}\text { weakly compressed to weakly depressed; } \\
\text { strongly embracing } \\
\text { (ww/wh }=0.90-1.20 ; \text { IZR }=0.35-0.40 \text { ) }\end{array}$ & $\begin{array}{l}\text { moderate to high } \\
(\mathrm{WER}=1.90-2.25)\end{array}$ \\
\hline
\end{tabular}

Table 26. Conch dimensions (in $\mathrm{mm}$ ) and proportions for reference specimens of Bollandoceras mirrih $\mathrm{n}$. sp.

\begin{tabular}{|c|c|c|c|c|c|c|c|c|c|c|}
\hline & $\mathrm{dm}$ & ww & wh & uw & ah & $w w / d m$ & ww/wh & $\mathrm{uw} / \mathrm{dm}$ & WER & IZR \\
\hline paratype MB.C.18692.11 & 25.7 & 14.0 & 12.1 & 4.4 & 7.8 & 0.54 & 1.16 & 0.17 & 2.06 & 0.36 \\
\hline holotype MB.C.18692.1 & 23.8 & 12.5 & 11.1 & 4.3 & 6.9 & 0.52 & 1.12 & 0.18 & 1.98 & 0.38 \\
\hline paratype MB.C.18692.9 & 21.0 & 10.1 & 10.0 & 3.4 & 6.1 & 0.48 & 1.01 & 0.16 & 1.99 & 0.39 \\
\hline paratype MB.C.18692.2 & 15.4 & 9.6 & 7.2 & 3.0 & 4.8 & 0.62 & 1.33 & 0.20 & 2.09 & 0.34 \\
\hline paratype MB.C.18692.10 & 14.0 & 8.0 & 6.3 & 3.4 & 3.8 & 0.57 & 1.28 & 0.25 & 1.89 & 0.39 \\
\hline paratype MB.C.18692.3 & 11.9 & 7.7 & 5.5 & 2.3 & 3.7 & 0.64 & 1.39 & 0.19 & 2.08 & 0.34 \\
\hline
\end{tabular}

Table 27. Suture line proportions (Figs 25D-F) for Bollandoceras mirrih n. sp.

\begin{tabular}{llllllll}
\hline specimen & at dm & EL w/d & EL/VLS & EL/AL & MS h & VLS w/h & remarks \\
\hline paratype MB.C.18692.8 & C. $28.0 \mathrm{~mm}$ & 0.59 & 0.89 & 1.02 & 0.22 & 0.67 & 0.71 \\
paratype MB.C.18692.7 & $22.7 \mathrm{~mm}$ & 0.60 & 0.84 & 1.01 & 0.21 & 0.66 & median saddle very low \\
paratype MB.C.18692.2 & $13.4 \mathrm{~mm}$ & 0.65 & 0.99 & 0.94 & 0.14 & 0.66 \\
\hline
\end{tabular}

Discussion. For a comparison with Bollandoceras zuhara, see under that species. B. mirrih differs from the species of the genus found in assemblages TIM-B2 and TIM-B3 in the much wider umbilicate inner whorls.

B. hodderense (Bisat, 1924) shows a similar conch geometry but possesses a shorter evolute juvenile stage. Adult specimens differ in the narrow external lobe of $B$. hodderense.

The co-occurring Gourarites hagaraswad and G. mustari differ in the longer evolute juvenile stage and the wider umbilicus at $20 \mathrm{~mm}$ conch diameter. Both species show a strong whorl overlap onto the umbilicus in the adult stage, causing a sudden decrease of the uw/dm ratio.

Figure 23. Bollandoceras zuhara n. sp. from locality TIM-C8. A. Cross section of paratype MB.C.18691.5; $\times 4.0$. B. Cross section of paratype MB.C.18691.6; ×4.0. C. Cross section of paratype MB.C.18691.7; ×4.0. D. Cross section of paratype MB.C.18691.8; $\times 4.0$. E. Cross section of paratype MB.C. $18691.9 ; \times 4.0$. F. Suture line of paratype MB.C.18691.10, at $11.8 \mathrm{~mm} \mathrm{dm,} 6.4 \mathrm{~mm}$ ww, $7.0 \mathrm{~mm}$ wh; $\times 5.0$. G. Suture line of paratype MB.C.18691.11, at $29.0 \mathrm{~mm} \mathrm{dm}, 16.0 \mathrm{~mm} \mathrm{wh} ; \times 3.5$. H-J. Ontogenetic development of the conch width index (ww/dm), umbilical width index (uw/dm), whorl width index (ww/wh), and whorl expansion rate (WER) of all available specimens. 


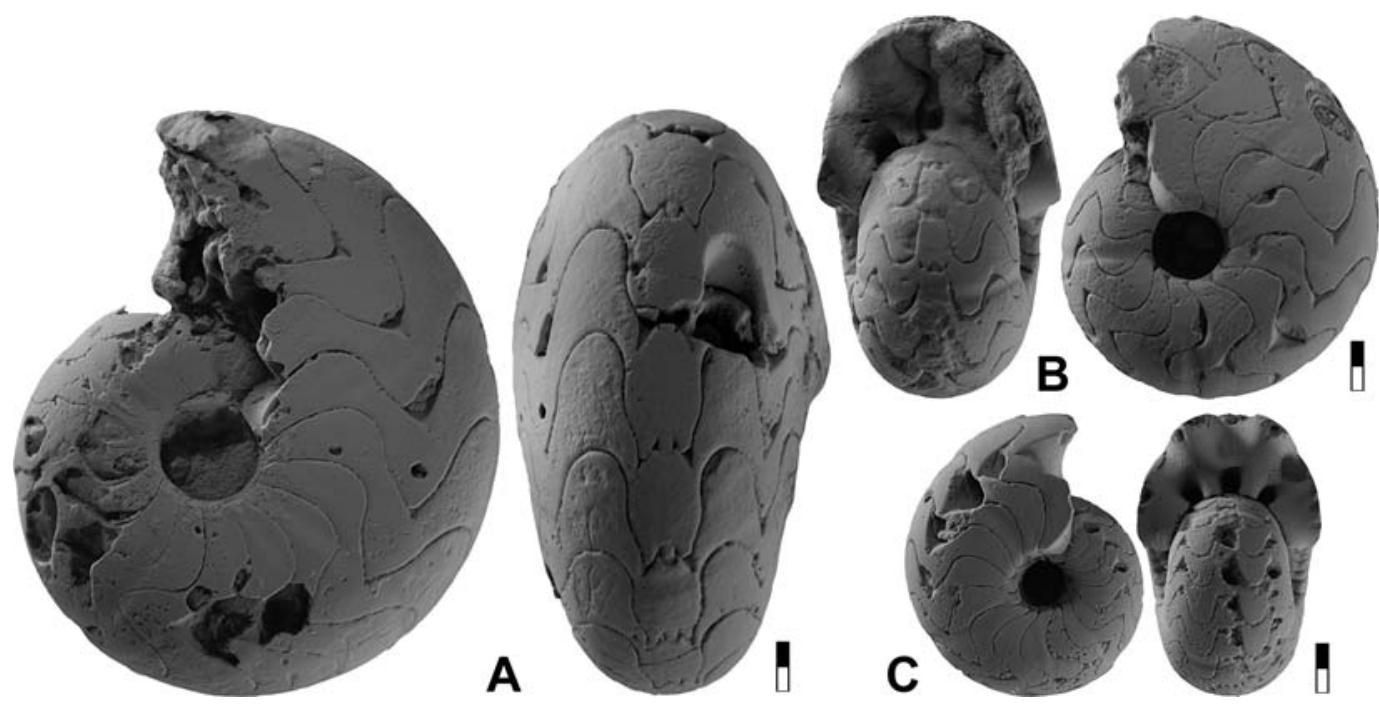

Figure 24. Bollandoceras mirrih n. sp. from locality TIM-C8; all ×2.5. A. Holotype MB.C.18692.1. B. Paratype MB.C.18692.2. C. Paratype MB.C.18692.3.
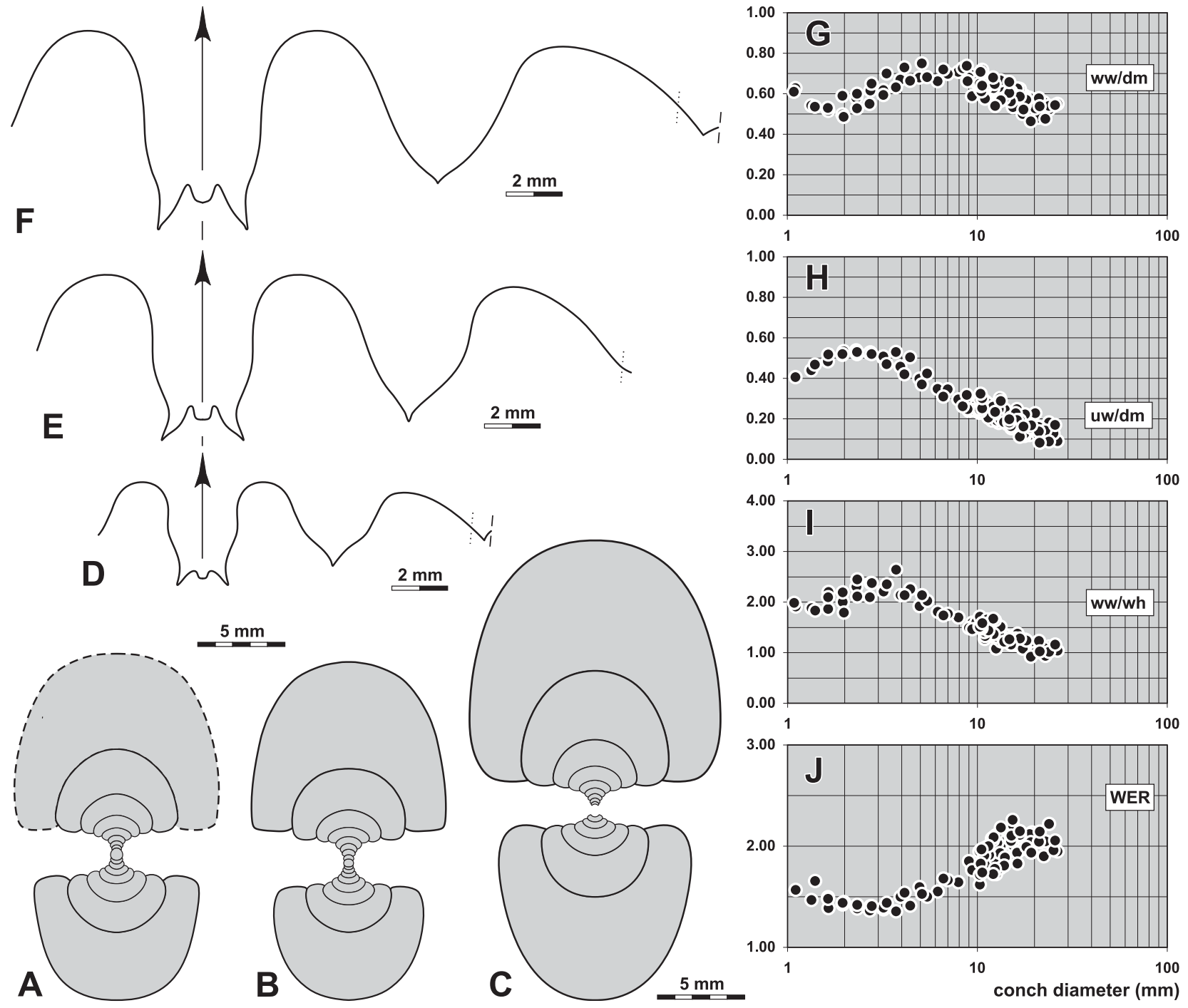

Figure 25. Bollandoceras mirrih n. sp. from locality TIM-C8. A. Cross section of paratype MB.C.18692.4; $\times 2.5$. B. Cross section of paratype MB.C. $18692.5 ; \times 2.5$. C. Cross section of paratype MB.C.18692.6; $\times 2.5$. D. Suture line of paratype MB.C.18692.2, at $13.4 \mathrm{~mm}$ $\mathrm{dm}, 8.2 \mathrm{~mm}$ ww, $6.4 \mathrm{~mm}$ wh; $\times$ 4.0. E. Suture line of paratype MB.C.18692.7, at $22.7 \mathrm{~mm} \mathrm{dm}, 13.3 \mathrm{~mm} w w, 12.9 \mathrm{~mm}$ wh; $\times 4.0$. F. Suture line of paratype MB.C.18692.8, at $13.9 \mathrm{~mm}$ ww, $13.6 \mathrm{~mm}$ wh; $\times 4.0$. G-J. Ontogenetic development of the conch width index (ww/dm), umbilical width index (uw/dm), whorl width index (ww/wh), and whorl expansion rate (WER) of all available specimens. 


\section{Benimehlalites n. gen.}

Derivation of name. After the village Beni Mehlal, a suburb of Timimoun.

Type species. Benimehlalites brinkmanni n. sp.

Diagnosis. Genus of the subfamily Maxigoniatitinae with thickly discoidal to pachyconic conch; conch ontogeny with striking transformations (Fig. 26); early juveniles subevolute and subsequent decrease of the uw/dm ratio; sudden opening of the umbilicus in the preadult stage by reduction of the whorl height and enlargement of the whorl width. Suture line with very narrow or narrow, diverging external lobe with sinuous flanks.

\section{Included species.}

belkassemensis: Benimehlalites belkassemensis n. sp.: Gourara, Algeria. benimehlalensis: Benimehlalites benimehlalensis n. sp.: Gourara, Algeria.

brinkmanni: Benimehlalites brinkmanni n. sp.: Gourara, Algeria.

? kaindynense: Bollandites? kaindynense (Popov, 1965): Tien Shan, Kyrgyzstan.

Discussion. Benimehlalites possesses a suture line similar to Bollandoceras, but the ontogeny of the conch shows conspicuous differences. Benimehlatites has a thickly discoidal or pachyconic adult conch (thinly discoidal in Bollandoceras) and an umbilicus that shows an accelerated opening rate in the middle growth stage. The genus $P a$ chybollandoceras has a similar adult conch, but differs in the evolute juvenile stage.
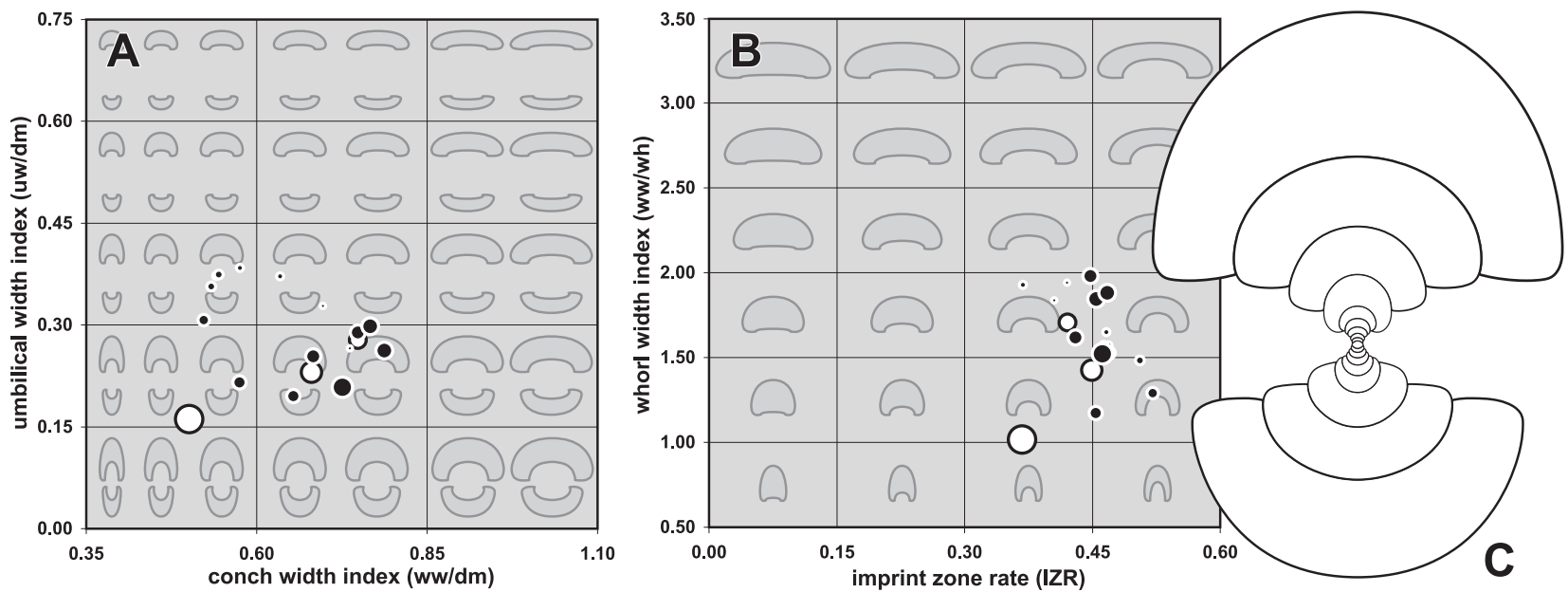

Figure 26. Ontogenetic trajectories of Benimehlalites, exemplified for Benimehlalites brinkmanni n. sp. from locality TIM-B3. A. Ontogenetic development of the conch width index $(\mathrm{ww} / \mathrm{dm})$ and umbilical width index (uw/dm). B. Ontogenetic development of the imprint zone rate (IZR) and whorl width index (ww/wh). C. Cross section of paratype MB.C.18688.5; $\times 2.0$. [Black dots represent ontogenetic stages of cross section MB.C.18688.4, white dots represent the reference specimens (Tab. 29).]

\section{Benimehlalites brinkmanni $\mathbf{n}$. sp.}

Figures 27, 28

Derivation of name. After Markus Brinkmann (Berlin), to honour his preparation work on the specimens.

Holotype. Specimen MB.C.18688.1, illustrated in Figure 27A.

Type locality and horizon. Sebkha de Timimoun, locality TIM-B3 (10 km west-southwest of Timimoun, Algeria); upper part of the Lower Bollandoceras-Bollandites Assemblage.

Material. 11 specimens, conch diameter between 20 and $103 \mathrm{~mm}$.

Diagnosis. Benimehlalites with very significant ontogenetic changes of conch geometry: conch pachyconic in the early juvenile stage (1 mm $\mathrm{dm})$, thereafter thickly discoidal $(2-7 \mathrm{~mm} \mathrm{dm})$, pachyconic $(8-40 \mathrm{~mm} \mathrm{dm})$, and finally thickly discoidal in the adult stage; juvenile stage $(1-$ $4 \mathrm{~mm} \mathrm{dm}$ ) subevolute, followed by a subinvolute stage $(4-16 \mathrm{~mm} \mathrm{dm}$ ), another subevolute stage (at $20 \mathrm{~mm} \mathrm{dm}$ ), and a final subinvolute adult stage; aperture strongly varying in height during ontogeny, low in juveniles and discontinuously increasing to moderate; umbilical margin rounded in all stages, only temporarily subangular. Steinkern smooth, occasionally with very weak constrictions. Suture line with narrow, rather strongly diverging external lobe with strongly sinuous flanks and low median saddle; ventrolateral saddle broadly rounded; shallow adventive lobe V-shaped, symmetric. 
Table 28. Conch ontogeny (Figs $28 \mathrm{~A}-\mathrm{C}, \mathrm{E}-\mathrm{G}$ ) of Benimehlalites brinkmanni $\mathrm{n}$. sp.

\begin{tabular}{|c|c|c|c|}
\hline$d m$ & conch shape & whorl cross section shape & aperture \\
\hline $3 \mathrm{~mm}$ & $\begin{array}{l}\text { thickly discoidal; subevolute } \\
(\mathrm{ww} / \mathrm{dm}=0.48-0.55 ; \mathrm{uw} / \mathrm{dm}=0.32-0.38)\end{array}$ & $\begin{array}{l}\text { weakly to moderately depressed; very strongly } \\
\text { embracing ( } w w / w h=1.25-1.60 ; \mathrm{IZR}=0.45-0.50 \text { ) }\end{array}$ & $\begin{array}{l}\text { low } \\
(\text { WER }=1.50-1.60)\end{array}$ \\
\hline $8 \mathrm{~mm}$ & $\begin{array}{l}\text { thickly discoidal to thinly pachyconic; subinvolute } \\
\text { (ww/dm }=0.55-0.65 \mathrm{uw} / \mathrm{dm}=0.15-0.20 \text { ) }\end{array}$ & $\begin{array}{l}\text { weakly depressed; very strongly embracing } \\
(\text { ww/wh }=1.20-1.50 ; \text { IZR }=0.45-0.50)\end{array}$ & $\begin{array}{l}\text { low } \\
(\text { WER }=1.65-1.75)\end{array}$ \\
\hline $20 \mathrm{~mm}$ & $\begin{array}{l}\text { thinly to thickly pachyconic; subinvolute to subevolute } \\
\text { (ww/dm }=0.65-0.80 ; \mathrm{uw} / \mathrm{dm}=0.25-0.35 \text { ) }\end{array}$ & $\begin{array}{l}\text { moderately depressed; very strongly embracing } \\
(\mathrm{ww} / \mathrm{wh}=1.50-2.00 ; \mathrm{IZR}=0.45-0.50)\end{array}$ & $\begin{array}{l}\text { moderate } \\
(\mathrm{WER}=1.75-1.90)\end{array}$ \\
\hline $35 \mathrm{~mm}$ & $\begin{array}{l}\text { thinly pachyconic; subinvolute } \\
(\mathrm{ww} / \mathrm{dm}=0.60-0.70 ; \mathrm{uw} / \mathrm{dm}=0.20-0.25)\end{array}$ & $\begin{array}{l}\text { weakly depressed; very strongly embracing } \\
(\mathrm{ww} / \mathrm{wh}=1.30-1.50 ; \mathrm{IZR}=0.45-0.50)\end{array}$ & $\begin{array}{l}\text { moderate } \\
(\mathrm{WER}=1.75-1.85)\end{array}$ \\
\hline $100 \mathrm{~mm}$ & $\begin{array}{l}\text { thickly discoidal; subinvolute } \\
\text { (ww/dm } \sim 0.50 ; \text { uw/dm } \sim 0.16 \text { ) }\end{array}$ & $\begin{array}{l}\text { weakly depressed; strongly embracing } \\
\text { (ww/wh } \sim 1.05 ; \text { IZR } \sim 0.36 \text { ) }\end{array}$ & $\begin{array}{l}\text { high } \\
(\text { WER } \sim 2.10)\end{array}$ \\
\hline
\end{tabular}

Table 29. Conch dimensions (in $\mathrm{mm}$ ) and proportions for reference specimens of Benimehlalites brinkmanni $\mathrm{n}$. sp.

\begin{tabular}{|c|c|c|c|c|c|c|c|c|c|c|}
\hline & $d m$ & ww & wh & uw & ah & $w w / d m$ & ww/wh & uw/dm & WER & IZR \\
\hline holotype MB.C.18688.1 & 102.7 & 51.0 & 49.7 & 16.2 & 31.9 & 0.50 & 1.03 & 0.16 & 2.10 & 0.36 \\
\hline paratype MB.C.18688.2 & 35.1 & 23.9 & 16.7 & 8.1 & 9.2 & 0.68 & 1.43 & 0.23 & 1.84 & 0.45 \\
\hline paratype MB.C. 18688.3 & 24.5 & 18.3 & 10.7 & 6.8 & 6.2 & 0.75 & 1.71 & 0.28 & 1.79 & 0.42 \\
\hline
\end{tabular}
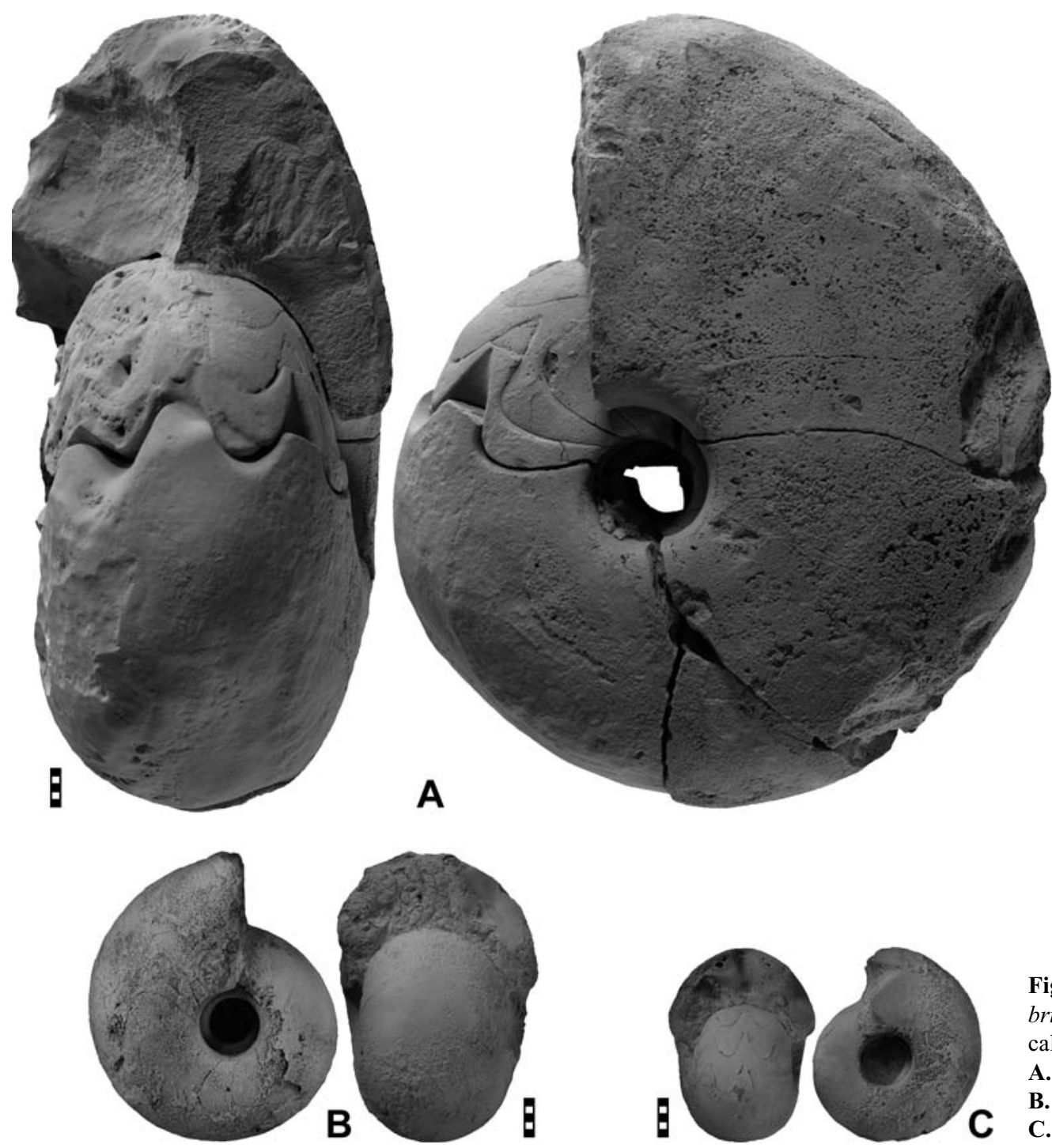

Figure 27. Benimehlalites brinkmanni n. sp. from locality TIM-B3; all $\times 1.0$. A. Holotype MB.C.18688.1. B. Paratype MB.C.18688.2

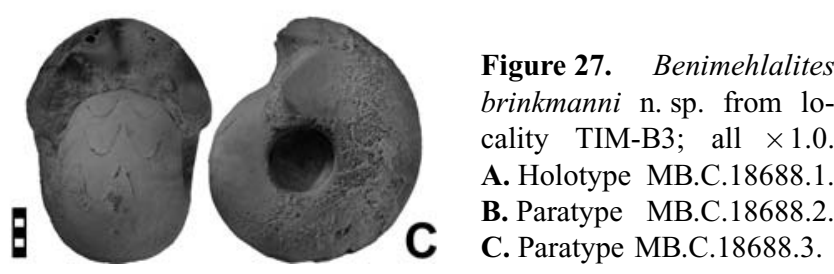


Table 30. Suture line proportions (Fig. 28D) for Benimehlalites brinkmanni n. sp.

\begin{tabular}{llllllll}
\hline specimen & at dm & EL w/d & EL/VLS & EL/AL & MS h & VLS w/h & remarks \\
\hline paratype MB.C.18688.3 & $17.0 \mathrm{~mm}$ & 0.62 & 0.69 & 1.02 & 0.23 & 0.89 & A lobe much shallower than E lobe \\
\hline
\end{tabular}

Discussion. Benimehlalites benimehlalensis differs in the less pronounced ontogenetic changes of the whorl cross section, which in Benimehlalites brinkmanni are particularly conspicuous at $7-10 \mathrm{~mm}$ conch diameter, where the umbilicus suddenly opens, caused by a significant reduction of the whorl height and compensation by strongly increasing whorl width. The external lobe of Benimehlalites benimehlalensis has much weaker diverging flanks. Benimehlalites belkassemensis differs in its strong steinkern constrictions.
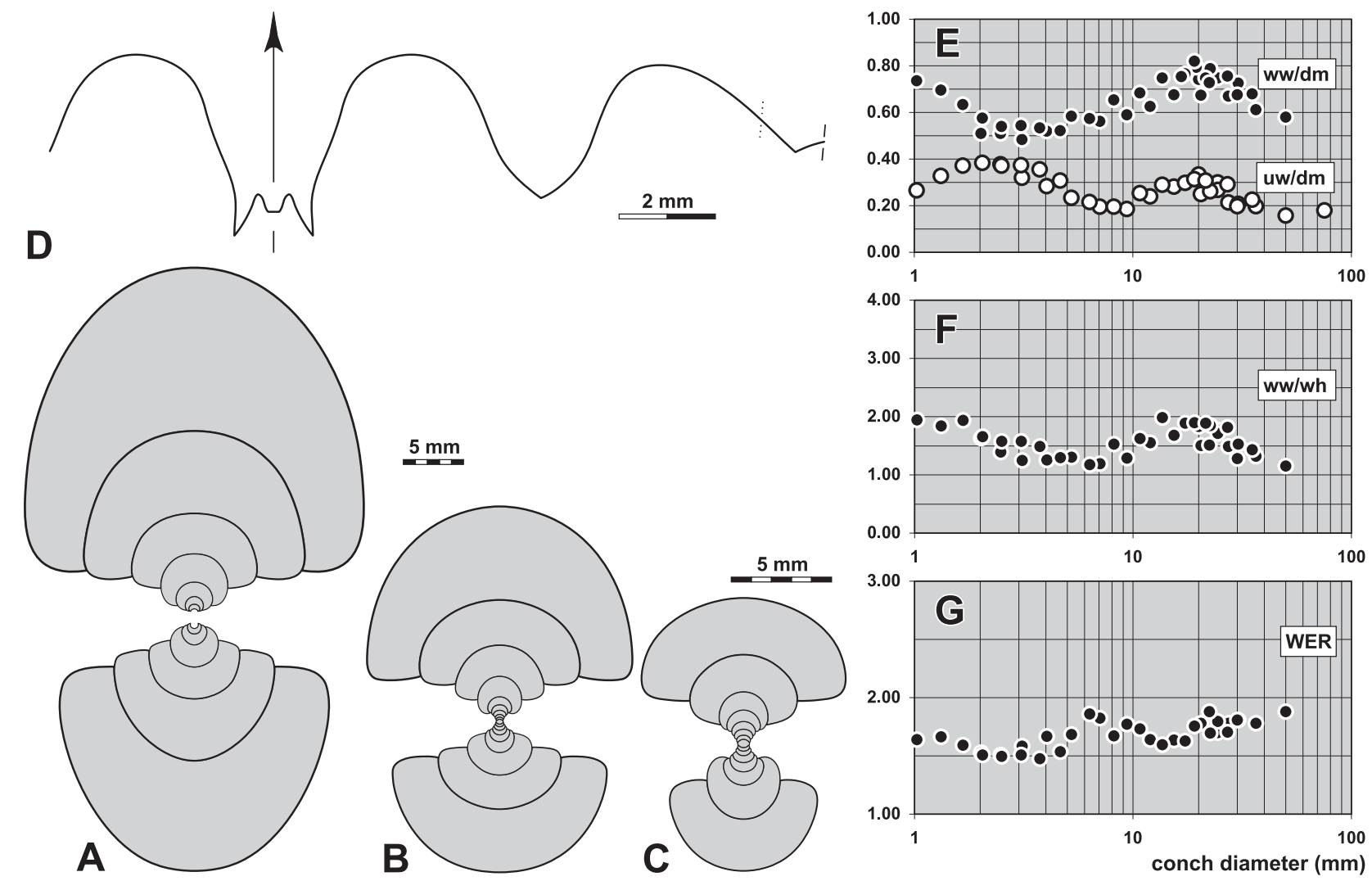

Figure 28. Benimehlalites brinkmanni n. sp. from locality TIM-B3. A. Cross section of paratype MB.C.18688.4; $\times 1.5$. B. Cross section of paratype MB.C.18688.5; $\times 1.5$. C. Cross section (inner whorls) of the same specimen; $\times 2.5$. D. Suture line of paratype MB.C.18688.3, at $17.0 \mathrm{~mm} \mathrm{dm}, 13.0 \mathrm{~mm}$ ww, $6.5 \mathrm{~mm}$ wh; $\times 6.0$. E-G. Ontogenetic development of the conch width index (ww/ $\mathrm{dm}$ ), umbilical width index (uw/dm), whorl width index (ww/wh), and whorl expansion rate (WER) of all available specimens.

\section{Benimehlalites benimehlalensis n. sp.}

Figures 29, 30

Derivation of name. After the village Beni Mehlal, a suburb of Timimoun.

Holotype. Specimen MB.C.18689.1, illustrated in Figure 29A.

Type locality and horizon. Sebkha de Timimoun, locality TIM-B3 (10 km west-southwest of Timimoun, Algeria); upper part of the Lower Bollandoceras-Bollandites Assemblage.

Material. Nine specimens, conch diameter between 20 and $53 \mathrm{~mm}$.

Diagnosis. Benimehlalites with significant ontogenetic changes in its conch geometry: conch thickly discoidal in the juvenile stage (1-5 mm $\mathrm{dm})$, thereafter thinly pachyconic $(6-20 \mathrm{~mm} \mathrm{dm})$, and finally thickly discoidal in the adult stage; juvenile stage (1-2.5 mm dm) subevolute, thereafter subinvolute to involute with an increase at $20 \mathrm{~mm} \mathrm{dm}$ and a final involute adult stage; aperture very low to low in juveniles (1-4 mm $\mathrm{dm}$ ) and then suddenly increasing to moderately high in the preadult stage and high in the adult stage; umbilical margin rounded in all stages. Steinkern smooth except for very shallow, almost straight constrictions in the intermediate stage. Suture line with very narrow, slightly diverging external lobe with slightly sinuous flanks and very low median saddle; ventrolateral saddle broadly rounded; adventive lobe V-shaped, symmetric. 
Table 31. Conch ontogeny (Figs 30A, C-E) of Benimehlalites benimehlalensis n. sp.

\begin{tabular}{|c|c|c|c|}
\hline $\mathrm{dm}$ & conch shape & whorl cross section shape & aperture \\
\hline $3 \mathrm{~mm}$ & $\begin{array}{l}\text { thickly discoidal; subevolute } \\
\text { (ww/dm } \sim 0.57 ; \text { uw/dm } \sim 0.30)\end{array}$ & $\begin{array}{l}\text { weakly depressed; very strongly embracing } \\
\text { (ww/wh } \sim 1.45 \text {; IZR } \sim 0.54 \text { ) }\end{array}$ & $\begin{array}{l}\text { low } \\
(\text { WER } \sim 1.50)\end{array}$ \\
\hline $8 \mathrm{~mm}$ & $\begin{array}{l}\text { thinly pachyconic; involute } \\
\text { (ww/dm } \sim 0.60 \text { uw/dm } \sim 0.10 \text { ) }\end{array}$ & $\begin{array}{l}\text { weakly depressed; very strongly embracing } \\
\text { (ww/wh } \sim 1.20 \text {; IZR } \sim 0.50 \text { ) }\end{array}$ & $\begin{array}{l}\text { moderate } \\
(\text { WER } \sim 1.80)\end{array}$ \\
\hline $20 \mathrm{~mm}$ & $\begin{array}{l}\text { thinly to thickly pachyconic; subinvolute } \\
\text { (ww/dm }=0.65-0.75 ; u w / d m=0.15-0.30)\end{array}$ & $\begin{array}{l}\text { weakly to moderately depressed; very strongly embracing } \\
(\mathrm{ww} / \mathrm{wh}=1.40-1.75 ; \mathrm{IZR}=0.45-0.50)\end{array}$ & $\begin{array}{l}\text { moderate } \\
(\text { WER }=1.75-2.00)\end{array}$ \\
\hline $35 \mathrm{~mm}$ & $\begin{array}{l}\text { thickly discoidal; involute } \\
\text { (ww/dm } \sim 0.57 ; \text { uw/dm } \sim 0.14\end{array}$ & $\begin{array}{l}\text { weakly depressed; very strongly embracing } \\
\text { (ww/wh } \sim 1.15 ; \text { IZR } \sim 0.45 \text { ) }\end{array}$ & $\begin{array}{l}\text { high } \\
\text { (WER 2.00) }\end{array}$ \\
\hline
\end{tabular}
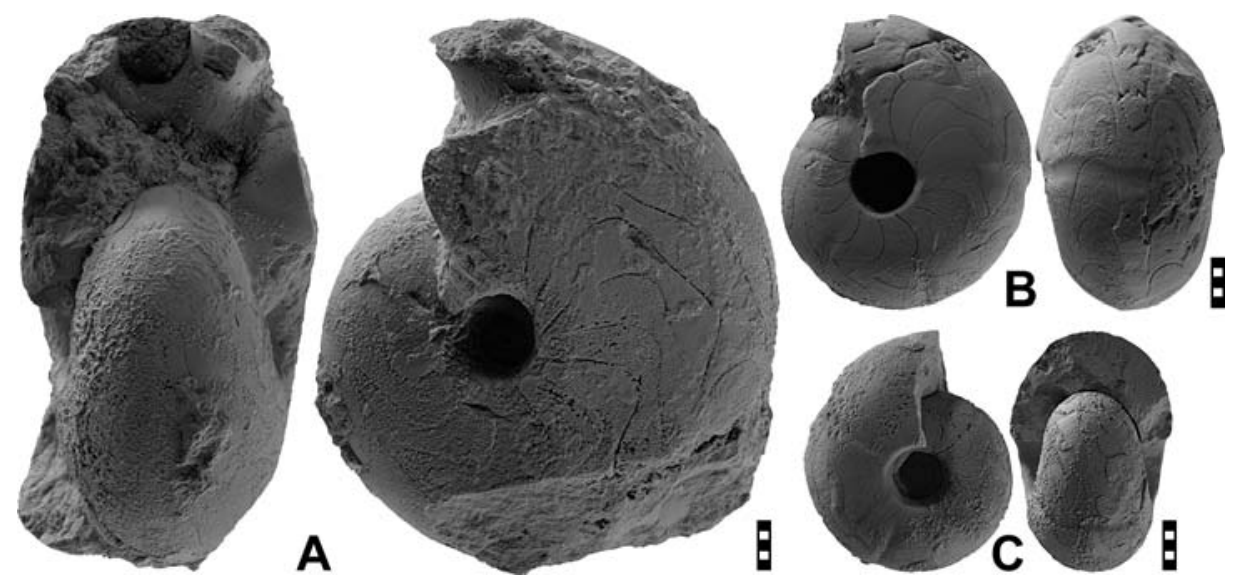

Figure 29. Benimehlalites benimehlalensis $\mathrm{n}$. sp. from locality TIM-B3; all $\times 1.0$.

A. Holotype MB.C.18689.1.

B. Paratype MB.C.18689.2.

C. Paratype MB.C.18689.3.
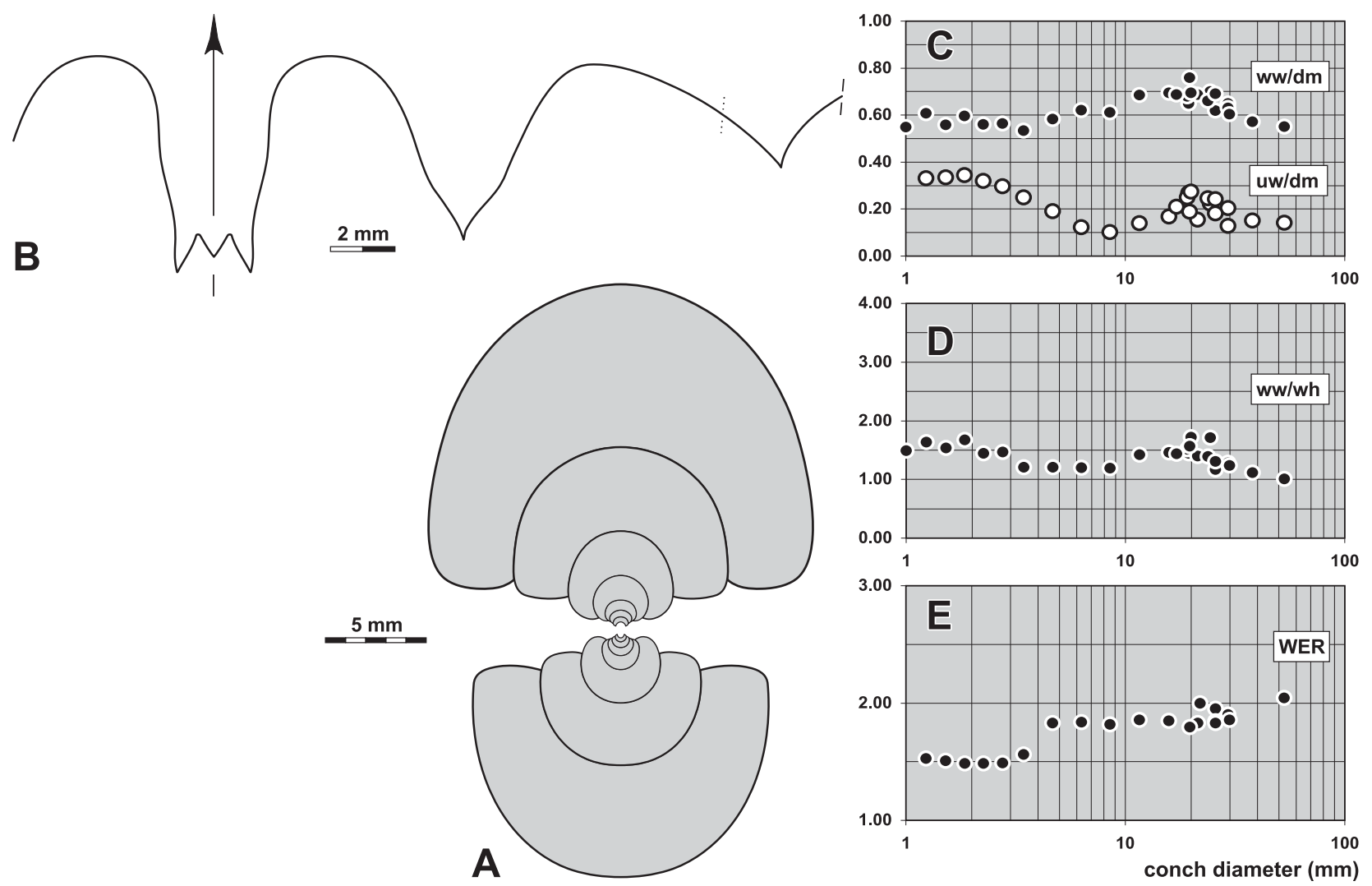

Figure 30. Benimehlalites benimehlalensis n. sp. from locality TIM-B3. A. Cross section of paratype MB.C.18689.4; $\times 2.5$. B. Suture line of paratype MB.C.18689.2, at $28.0 \mathrm{~mm} \mathrm{dm}, 18.0 \mathrm{~mm}$ ww, $14.5 \mathrm{~mm}$ wh; $\times 4.0$. C-E. Ontogenetic development of the conch width index (ww/dm), umbilical width index (uw/dm), whorl width index (ww/wh), and whorl expansion rate (WER) of all available specimens. 
Table 32. Conch dimensions (in $\mathrm{mm}$ ) and proportions for reference specimens of Benimehlalites brinkmanni $\mathrm{n}$. sp.

\begin{tabular}{lllllllllll}
\hline & $\mathrm{dm}$ & ww & wh & uw & ah & ww/dm & ww/wh & uw/dm & WER & IZR \\
\hline holotype MB.C.18689.1 & 52.9 & 29.2 & 29.0 & 7.5 & 15.9 & 0.55 & 1.01 & 0.14 & 2.04 & 0.45 \\
paratype MB.C.18689.2 & 29.3 & 18.5 & 14.4 & 6.0 & 8.5 & 0.63 & 1.28 & 0.20 & 1.98 & 0.41 \\
paratype MB.C.18689.3 & 25.8 & 16.1 & 12.2 & 6.2 & 6.8 & 0.63 & 1.32 & 0.24 & 1.85 & 0.44 \\
paratype MB.C.18689.5 & 24.4 & 17.1 & 10.4 & 5.5 & 6.1 & 0.70 & 1.64 & 0.22 & 1.77 & 0.42 \\
\hline
\end{tabular}

Table 33. Suture line proportions (Fig. 30B) for Benimehlalites brinkmanni n. sp.

\begin{tabular}{llllllll}
\hline specimen & at dm & EL w/d & EL/VLS & EL/AL & MS h & VLS w/h & remarks \\
\hline paratype MB.C.18689.2 & $28.0 \mathrm{~mm}$ & 0.49 & 0.69 & 1.05 & 0.17 & 0.71 & A lobe as deep as E lobe \\
\hline
\end{tabular}

Discussion. Benimehlalites benimehlalensis shows some affinities to the stouter species of the genus Bollandoceras, but differs in the adult re-opening of the umbilicus. Benimehlalites benimehlalensis possesses a less stout conch than the type species and less striking ontogenetic changes in the whorl cross section. Benimehlalites belkassemensis differs in its strong steinkern constrictions and its wider external lobe.

\section{Benimehlalites belkassemensis n. sp.}

Figures 31, 32

Derivation of name. After the ruin Zrîbet Sidi el Hadj Belkassem near Timimoun.

Holotype. Specimen MB.C.18684.1, illustrated in Figure 31.

Type locality and horizon. Sebkha de Timimoun, locality TIM-B2 (10 km west-southwest of Timimoun, Algeria); lower part of the Lower Bollandoceras-Bollandites Assemblage.

Material. Two specimens, conch diameters 38 and $51 \mathrm{~mm}$.

Diagnosis. Benimehlalites with major ontogenetic changes of the conch geometry: conch globular in the early juvenile stage and discontinuously becoming thinly pachyconic at $20 \mathrm{~mm} \mathrm{dm}$, slight increase of the ww/dm ratio between 4 and $16 \mathrm{~mm}$ dm; early juvenile stage subinvolute and involute at $4 \mathrm{~mm} \mathrm{dm}$, becoming subinvolute or subevolute above $6 \mathrm{~mm} \mathrm{dm}$ and throughout later ontogeny; aperture height very variable between low and high; umbilical margin rounded in juveniles and angular in the middle and adult stage. Steinkern with constrictions with convex course. Suture line with narrow, slightly diverging external lobe with strongly sinuous flanks, very narrow secondary prongs, and low median saddle; ventrolateral saddle broadly rounded; adventive lobe V-shaped, symmetric and slightly pouched.

Table 34. Conch ontogeny (Figs 32A, B, D-F) of Benimehlalites belkassemensis n. sp.

\begin{tabular}{|c|c|c|c|}
\hline $\mathrm{dm}$ & conch shape & whorl cross section shape & aperture \\
\hline $3 \mathrm{~mm}$ & $\begin{array}{l}\text { thickly pachyconic; subinvolute } \\
\text { (ww/dm } \sim 0.74 ; \text { uw/dm } \sim 0.16 \text { ) }\end{array}$ & $\begin{array}{l}\text { weakly depressed; strongly embracing } \\
\text { (ww/wh } \sim 1.40 ; \text { IZR } \sim 0.40 \text { ) }\end{array}$ & $\begin{array}{l}\text { high } \\
(\text { WER } \sim 2.05)\end{array}$ \\
\hline $8 \mathrm{~mm}$ & $\begin{array}{l}\text { thinly pachyconic; subinvolute } \\
\text { (ww/dm } \sim 0.70 ; \mathrm{uw} / \mathrm{dm} \sim 0.18 \text { ) }\end{array}$ & $\begin{array}{l}\text { moderately depressed; very strongly embracing } \\
\text { (ww/wh } \sim 1.60 ; \text { IZR } \sim 0.50 \text { ) }\end{array}$ & $\begin{array}{l}\text { low } \\
(\text { WER } \sim 1.70)\end{array}$ \\
\hline $20 \mathrm{~mm}$ & $\begin{array}{l}\text { thinly pachyconic; subevolute } \\
\text { (ww/dm } \sim 0.70 ; \mathrm{uw} / \mathrm{dm} \sim 0.32 \text { ) }\end{array}$ & $\begin{array}{l}\text { moderately depressed; strongly embracing } \\
\text { (ww/wh } \sim 1.80 ; \text { IZR } \sim 0.42 \text { ) }\end{array}$ & $\begin{array}{l}\text { low } \\
(\text { WER } \sim 1.65)\end{array}$ \\
\hline $35 \mathrm{~mm}$ & $\begin{array}{l}\text { thinly pachyconic; subinvolute } \\
\text { (ww/dm } \sim 0.65 ; \text { uw/dm } \sim 0.25 \text { ) }\end{array}$ & $\begin{array}{l}\text { moderately depressed; strongly embracing } \\
\text { (ww/wh } \sim 1.50 ; \text { IZR } \sim 0.45 \text { ) }\end{array}$ & $\begin{array}{l}\text { high } \\
(\text { WER } \sim 2.15)\end{array}$ \\
\hline
\end{tabular}

Table 35. Conch dimensions (in $\mathrm{mm}$ ) and proportions for reference specimens of Benimehlalites belkassemensis n. sp.

\begin{tabular}{llllllllll}
\hline & $\mathrm{dm}$ & ww & wh & uw & ah & ww/dm & ww/wh & uw/dm & WER \\
\hline holotype MB.C.18684.1 & 51.6 & - & 23.6 & 12.9 & 16.5 & - & - & 0.25 & 2.16 \\
dto. & 37.2 & 23.2 & 15.5 & 11.8 & - & 0.62 & 1.50 & 0.32 & - \\
\hline
\end{tabular}

Table 36. Suture line proportions (Fig. 32C) for Benimehlalites belkassemensis n. sp.

\begin{tabular}{llllllll}
\hline specimen & at dm & EL w/d & EL/VLS & EL/AL & MS h & VLS w/h & remarks \\
\hline holotype MB.C.18684.1 & $32.0 \mathrm{~mm}$ & 0.57 & 0.70 & 0.91 & 0.20 & 0.81 & E lobe prongs hook-shaped \\
\hline
\end{tabular}


Discussion. Benimehlalites belkassemensis differs in its strong steinkern constrictions and the stronger curved flanks of the external lobe from the two species Benimehlalites brinkmanni and Benimehlalites benimehlalensis, which occur in the higher horizon TIM-B3.

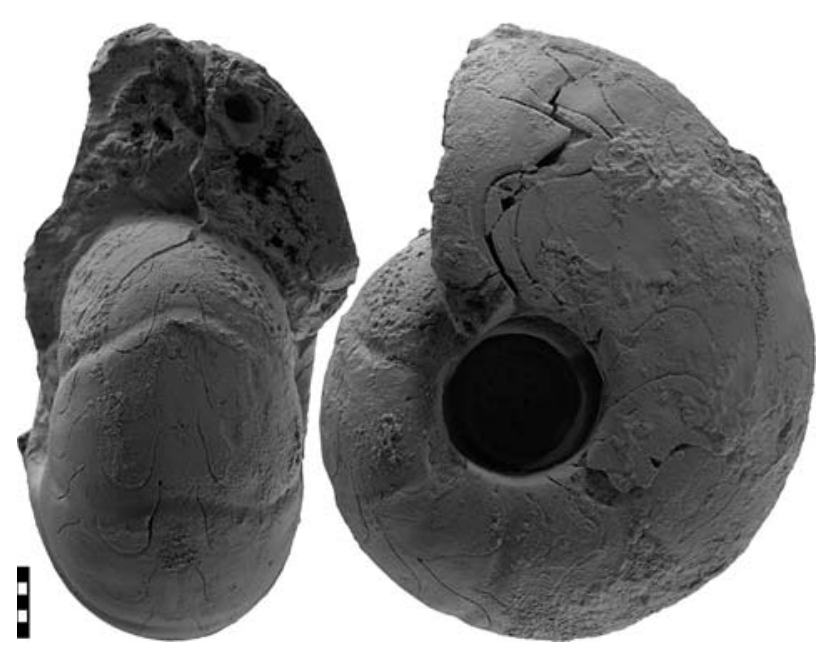

Figure 31. Benimehlalites belkassemensis n. sp. from locality TIM-B2; holotype MB.C. $18684.1 ; \times 1.25$.
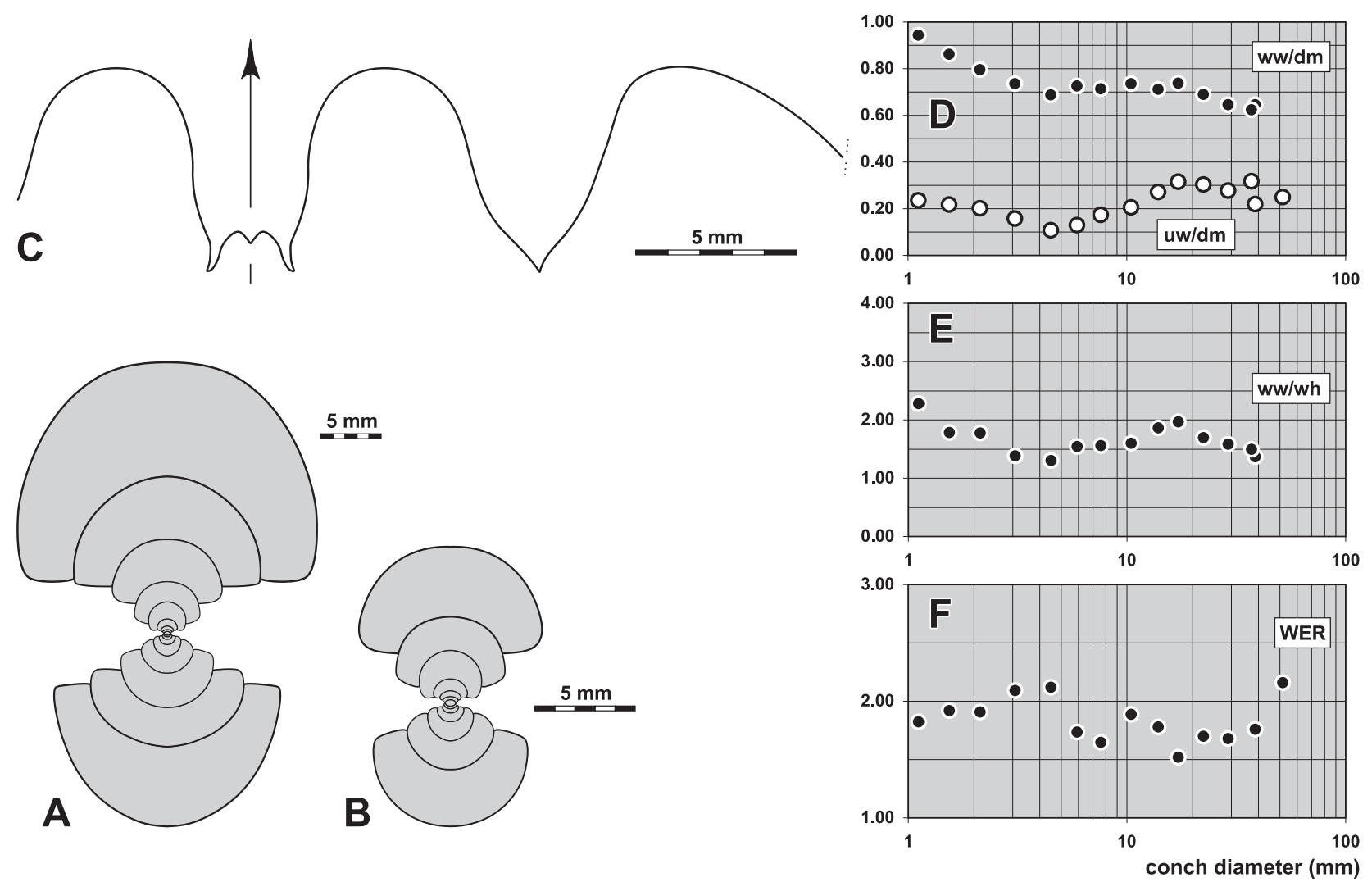

Figure 32. Benimehlalites belkassemensis n. sp. from locality TIM-B2. A. Cross section of paratype MB.C.18684.2; $\times 1.5$. B. Cross section (inner whorls) of the same specimen; $\times 2.5$. C. Suture line of holotype MB.C.18684.1, at $32.0 \mathrm{~mm} \mathrm{dm}, 21.0 \mathrm{~mm}$ ww, $10.0 \mathrm{~mm}$ wh; $\times 4.0$. D-F. Ontogenetic development of the conch width index (ww/dm), umbilical width index (uw/dm), whorl width index (ww/wh), and whorl expansion rate (WER) of all available specimens.

\section{Pachybollandoceras n. gen.}

Derivation of name. Reference to the genus Bollandoceras, which possesses a more slender conch.

Type species. Pachybollandoceras intraevolutum n. sp.

Diagnosis. Genus of the subfamily Maxigoniatitinae with pachyconic adult conch; conch ontogeny with striking transformations (Fig. 33); early juveniles evolute and rapid decrease of the uw/dm ratio early in ontogeny; slight opening of the umbilicus in the preadult stage by reduction of 
the whorl height and enlargement of the whorl width. Suture line with narrow, diverging external lobe with sinuous flanks and very low median saddle.

Included species.

intraevolutum: Pachybollandoceras intraevolutum n. sp.: Gourara, Algeria.

repens: Pachybollandoceras repens n. sp.: Gourara, Algeria.

Discussion. Pachybollandoceras possesses a suture line similar to Bollandoceras, but the ontogeny of the conch shows conspicuous differences. Pachybollandoceras has a pachyconic adult conch (discoidal in Bollandoceras) and the umbilicus closes much faster. Contrary to Bollandoceras, Pachybollandoceras shows irregular widening of the conch in the adult stage.
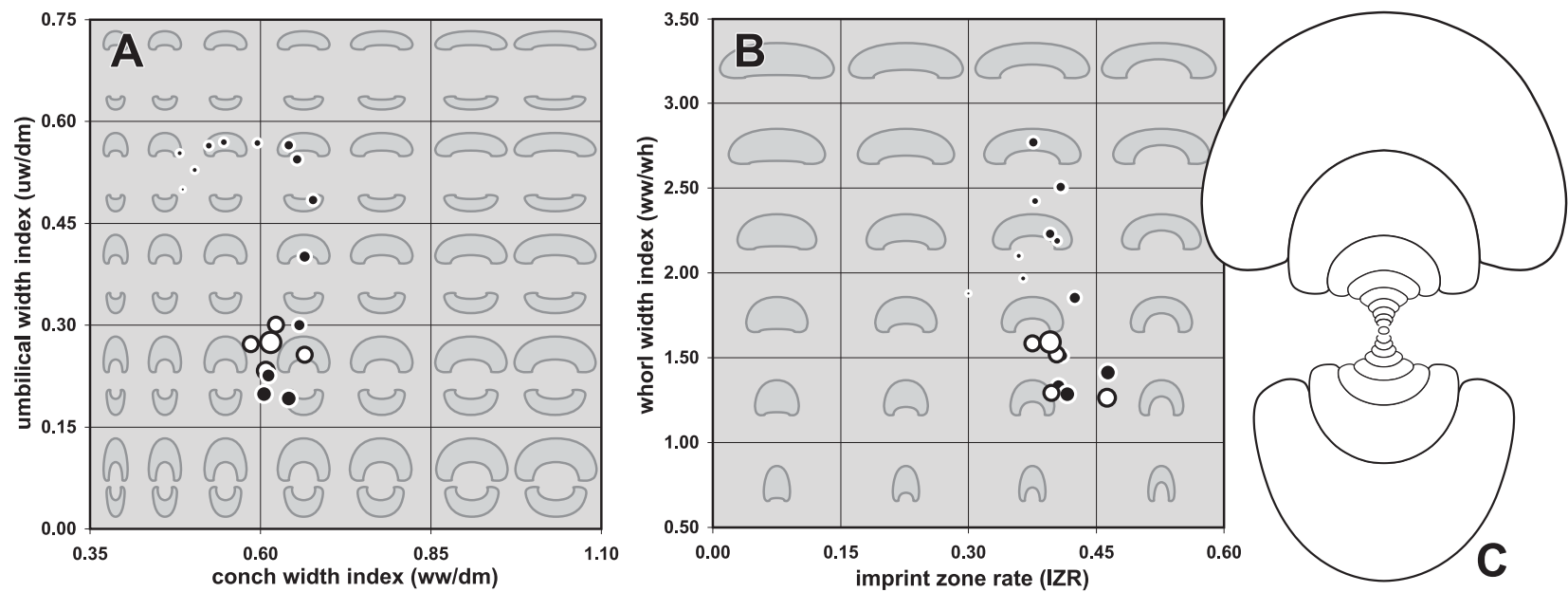

Figure 33. Ontogenetic trajectories of Pachybollandoceras, exemplified for P. intraevolutum n. sp. from locality TIM-C8. A. Ontogenetic development of the conch width index (ww/dm) and umbilical width index (uw/dm). B. Ontogenetic development of the imprint zone rate (IZR) and whorl width index (ww/wh). C. Cross section of paratype MB.C.18693.4; $\times 2.5$. [Black dots represent ontogenetic stages of cross section MB.C.18693.4, white dots represent the reference specimens (Tab. 38).]

\section{Pachybollandoceras intraevolutum n. sp.}

Figures 34, 35

Derivation of name. Named after the very evolute inner whorls.

Holotype. Specimen MB.C.18693.1, illustrated in Figure 34A.

Type locality and horizon. Sebkha de Timimoun, locality TIM-C8 (13.3 km west of Timimoun, Algeria); Upper Bollandoceras-Bollandites Assemblage.

Material. 16 specimens, conch diameter between 10 and $26 \mathrm{~mm}$.

Diagnosis. Pachybollandoceras with major ontogenetic changes of its conch geometry: conch evolute in the juvenile and intermediate stage (at $1-6 \mathrm{~mm} \mathrm{dm}$ ) and then becoming subevolute at $10 \mathrm{~mm} \mathrm{dm}$; conch thickly discoidal in the early juvenile stage and thinly pachyconic in stages above $4 \mathrm{~mm} \mathrm{dm}$; aperture very low in juveniles $(2-6 \mathrm{~mm} \mathrm{dm}$ ) and then slowly increasing (moderately high $20 \mathrm{~mm} \mathrm{dm}$ ); umbilical margin rounded in juveniles and subangular in the adult stage. Steinkern with shallow, nearly linear constrictions. Suture line with narrow, diverging external lobe with sinuous flanks and very low median saddle; ventrolateral saddle broadly rounded; adventive lobe V-shaped, almost symmetric.

Table 37. Conch ontogeny (Figs 35A, B, E-G) of Pachybollandoceras intraevolutum n. sp.

\begin{tabular}{|c|c|c|c|}
\hline $\mathrm{dm}$ & conch shape & whorl cross section shape & aperture \\
\hline $2 \mathrm{~mm}$ & $\begin{array}{l}\text { thickly discoidal; evolute } \\
\text { (ww/dm } \sim 0.50 ; \text { uw/dm } \sim 0.55 \text { ) }\end{array}$ & $\begin{array}{l}\text { strongly depressed; strongly embracing } \\
\text { (ww/wh } \sim 2.05 ; \text { IZR } \sim 0.35 \text { ) }\end{array}$ & $\begin{array}{l}\text { very low } \\
(\text { WER } \sim 1.40)\end{array}$ \\
\hline $8 \mathrm{~mm}$ & $\begin{array}{l}\text { thinly pachyconic; subevolute } \\
\text { (ww/dm } \sim 0.68 ; \text { uw/dm } \sim 0.35\end{array}$ & $\begin{array}{l}\text { moderately depressed; strongly embracing } \\
\text { (ww/wh } \sim 1.70 ; \mathrm{IZR}=0.42 \text { ) }\end{array}$ & $\begin{array}{l}\text { low } \\
(\text { WER } \sim 1.70)\end{array}$ \\
\hline $20 \mathrm{~mm}$ & $\begin{array}{l}\text { thinly pachyconic; subinvolute } \\
\text { (ww/dm }=0.60-0.65 ; \mathrm{uw} / \mathrm{dm}=0.20-0.30 \text { ) }\end{array}$ & $\begin{array}{l}\text { weakly to moderately depressed; strongly to } \\
\text { very strongly embracing } \\
\text { (ww/wh }=1.30-1.60 ; \text { IZR }=0.40-0.50 \text { ) }\end{array}$ & $\begin{array}{l}\text { moderate } \\
(\mathrm{WER}=1.65-1.90)\end{array}$ \\
\hline
\end{tabular}




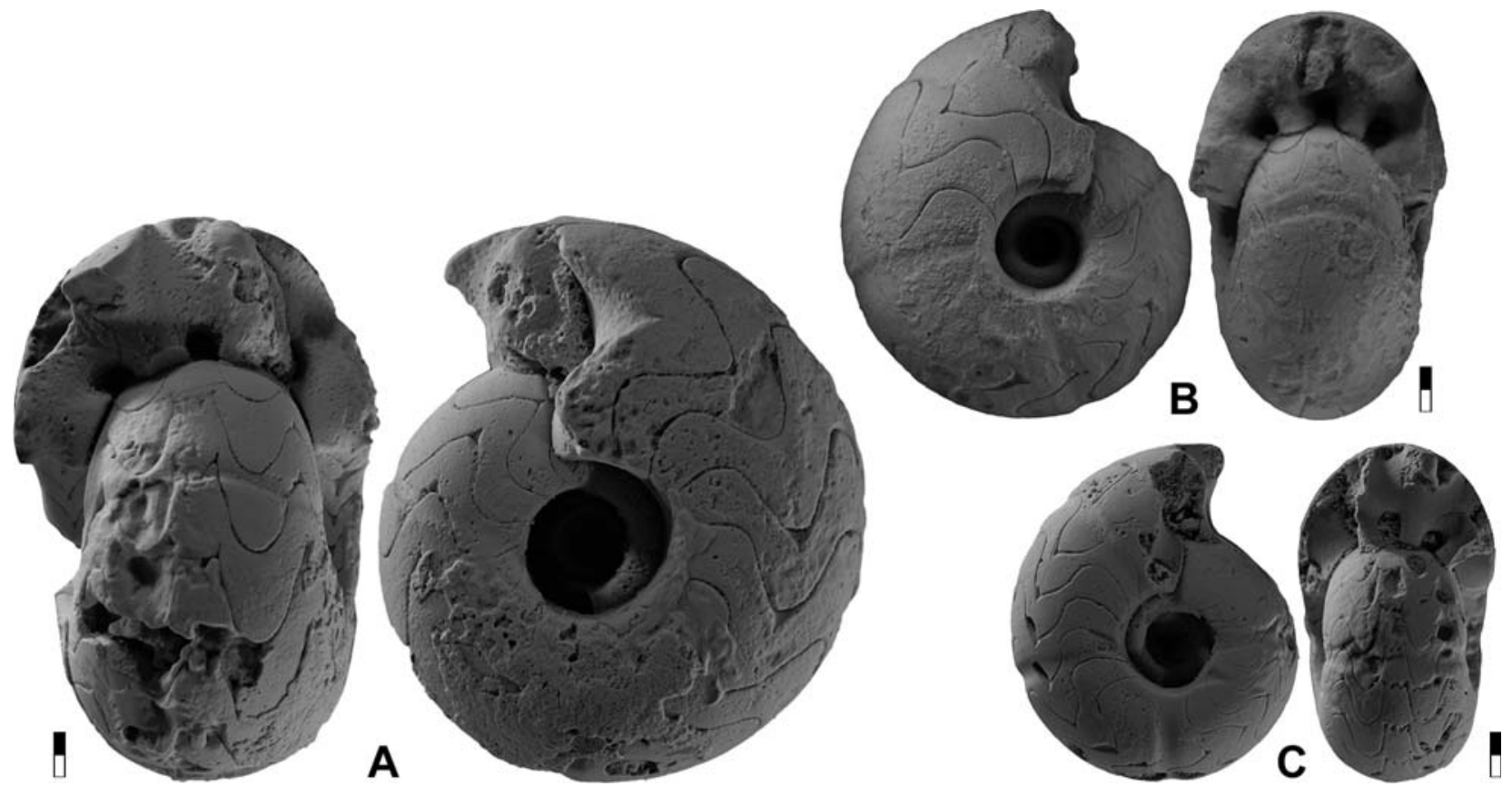

Figure 34. Pachybollandoceras intraevolutum n. sp. from locality TIM-C8; all ×2.5. A. Holotype MB.C.18693.1. B. Paratype MB.C.18693.2. C. Paratype MB.C.18693.3.
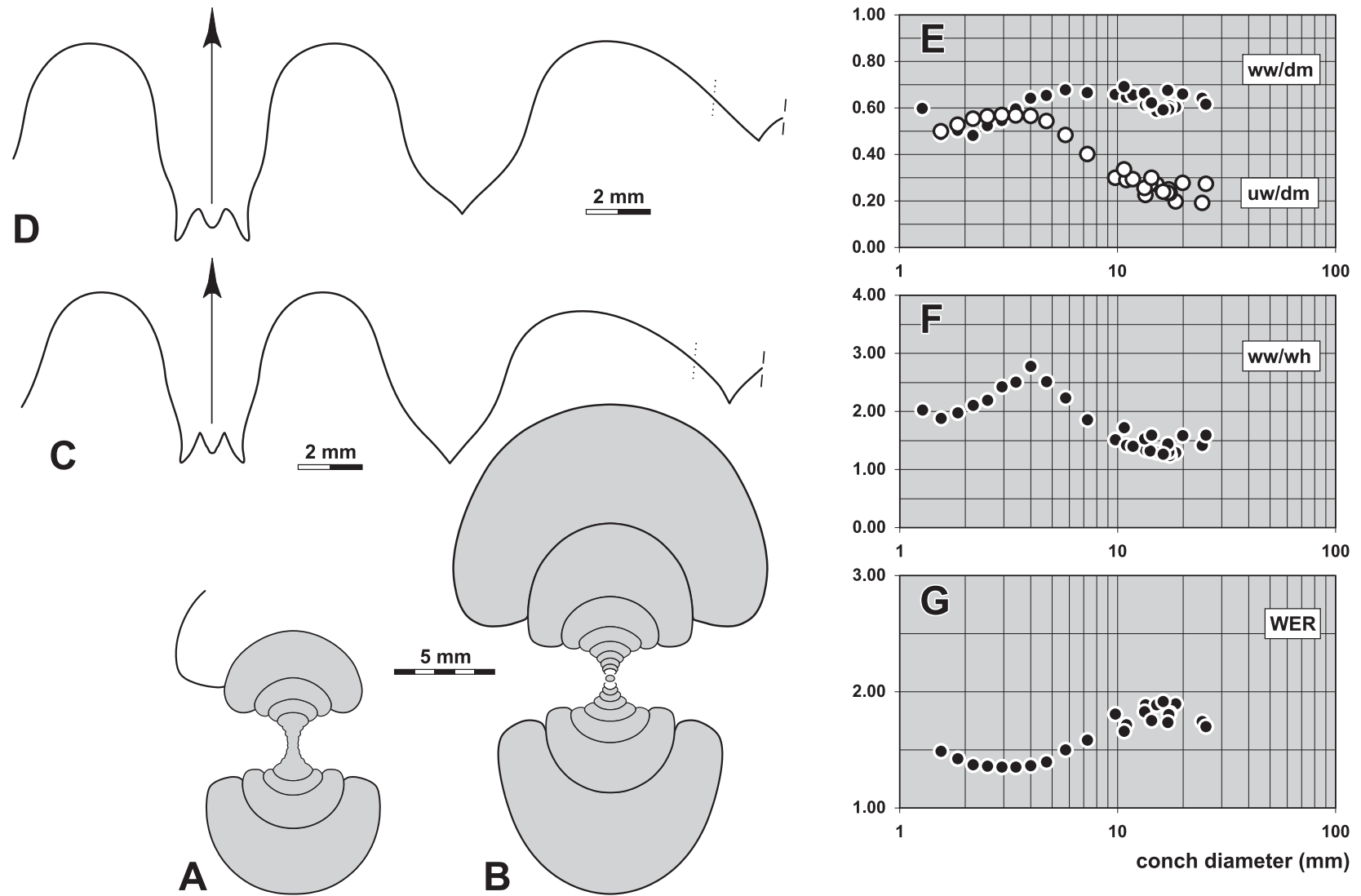

Figure 35. Pachybollandoceras intraevolutum n. sp. from locality TIM-C8. A. Cross section of paratype MB.C.18693.5; $\times 2.5$. B. Cross section of paratype MB.C. $18693.4 ; \times 2.5$. C. Suture line of holotype MB.C.18693.1, at $20.0 \mathrm{~mm} \mathrm{dm,} 10.4 \mathrm{~mm}$ ww; $\times 4.0$. D. Suture line of paratype MB.C.18693.4, at $12.2 \mathrm{~mm}$ ww, $10.4 \mathrm{~mm} \mathrm{wh} \times 4.0$. E-G. Ontogenetic development of the conch width index (ww/dm), umbilical width index (uw/dm), whorl width index (ww/wh), and whorl expansion rate (WER) of all available specimens. 
Table 38. Conch dimensions (in $\mathrm{mm}$ ) and proportions for reference specimens of Pachybollandoceras intraevolutum $\mathrm{n}$. $\mathrm{sp}$.

\begin{tabular}{lccccccccccc}
\hline & $\mathrm{dm}$ & ww & wh & uw & ah & ww/dm & ww/wh & uw/dm & WER & IZR \\
\hline holotype MB.C.18693.1 & 25.4 & 15.6 & 9.8 & 7.0 & 5.9 & 0.62 & 1.60 & 0.27 & 1.70 & 0.40 \\
paratype MB.C.18693.2 & 17.3 & 10.5 & 8.3 & 4.0 & 4.5 & 0.61 & 1.27 & 0.23 & 1.81 & 0.46 \\
paratype MB.C.18693.3 & 15.1 & 8.9 & 6.8 & 4.1 & 4.1 & 0.59 & 1.30 & 0.27 & 1.89 & 0.40 \\
paratype MB.C.18693.7 & 14.3 & 8.9 & 5.6 & 4.3 & 3.5 & 0.62 & 1.59 & 0.30 & 1.75 & 0.38 \\
paratype MB.C.18693.6 & 13.3 & 8.8 & 5.8 & 3.4 & 3.5 & 0.66 & 1.52 & 0.26 & 1.83 & 0.40 \\
\hline
\end{tabular}

Table 39. Suture line proportions (Figs 35C, D) for Pachybollandoceras intraevolutum n. sp.

\begin{tabular}{llllllll}
\hline specimen & at dm & EL w/d & EL/VLS & EL/AL & MS h & VLS w/h & remarks \\
\hline paratype MB.C.18693.4 & c. $22.0 \mathrm{~mm}$ & 0.54 & 0.76 & 0.86 & 0.16 & 0.72 & A lobe pouched \\
holotype MB.C.18693.1 & c. $20.0 \mathrm{~mm}$ & 0.54 & 0.72 & 0.80 & 0.17 & 0.75 & A lobe V-shaped \\
\hline
\end{tabular}

Discussion. Pachybollandoceras intraevolutum is separated from P. repens in the wider umbilicus in the adult stage (uw/dm $>0.20$ ). The suture line of $P$. intraevolutum shows an external lobe with much stronger sinuous flanks.

\section{Pachybollandoceras repens n. sp.}

Figures 36, 37

Derivation of name. From Latin repens = suddenly, because of the sudden widening of the conch.

Holotype. Specimen MB.C.18694.1, illustrated in Figure 36A.

Type locality and horizon. Sebkha de Timimoun, locality TIM-C8 (13.3 km west of Timimoun, Algeria); Upper Bollandoceras-Bollandites Assemblage.

Material. 23 specimens, conch diameter between 7 and $20 \mathrm{~mm}$.

Diagnosis. Pachybollandoceras with major ontogenetic changes of its conch geometry: conch evolute in the juvenile stage (at 1-3 $\mathrm{mm} \mathrm{dm}$ ) and then becoming subevolute at $6 \mathrm{~mm} \mathrm{dm}$; conch thickly discoidal in the early juvenile stage and thinly pachyconic in stages above $3 \mathrm{~mm} d \mathrm{~m}$; aperture very low in juveniles $(2-4 \mathrm{~mm} \mathrm{dm}$ ) and then slowly increasing (moderately high $20 \mathrm{~mm} \mathrm{dm}$ ); umbilical margin rounded in juveniles and subangular in the adult stage. Steinkern with very shallow, nearly linear constrictions. Suture line with narrow, diverging external lobe with slightly sinuous flanks and very low median saddle; ventrolateral saddle broadly rounded; adventive lobe V-shaped, asymmetric.

Table 40. Conch ontogeny (Figs 37A, C-E) of Pachybollandoceras repens n. sp.

\begin{tabular}{llll}
\hline $\mathrm{dm}$ & conch shape & whorl cross section shape & aperture \\
\hline $2 \mathrm{~mm}$ & thickly discoidal; evolute & moderately depressed; strongly embracing & very low \\
& $($ ww/dm $\sim 0.48 ;$ uw/dm $\sim 0.53)$ & (ww/wh $\sim 1.95 ;$ IZR $\sim 0.40)$ & $($ WER $\sim 1.40)$ \\
$8 \mathrm{~mm}$ & thinly pachyconic; subinvolute & weakly depressed; very strongly embracing & moderate \\
& $($ ww/dm $\sim 0.68 ;$ uw/dm $\sim 0.25)$ & (ww/wh $\sim 1.40 ;$ IZR $\sim 0.45)$ & $($ WER $\sim 1.80)$ \\
$20 \mathrm{~mm}$ & thinly pachyconic; subinvolute & weakly depressed; very strongly embracing & low \\
& $($ ww/dm $\sim 0.65 ;$ uw/dm $\sim 0.20)$ & $($ ww/wh $\sim 1.45 ;$ IZR $\sim 0.50)$ & $($ WER $\sim 1.70)$
\end{tabular}

Table 41. Conch dimensions (in $\mathrm{mm}$ ) and proportions for reference specimens of Pachybollandoceras repens $\mathrm{n}$. sp.

\begin{tabular}{lcccccccccc}
\hline & dm & ww & wh & uw & ah & ww/dm & ww/wh & uw/dm & WER & IZR \\
\hline holotype MB.C.18694.1 & 19.8 & 13.1 & 8.8 & 3.8 & 4.5 & 0.66 & 1.49 & 0.19 & 1.67 & 0.49 \\
paratype MB.C.18694.4 & 14.4 & 9.4 & 6.2 & 3.7 & 3.7 & 0.65 & 1.51 & 0.25 & 1.79 & 0.41 \\
paratype MB.C.18694.5 & 13.0 & 9.2 & 6.0 & 3.7 & 3.2 & 0.70 & 1.53 & 0.28 & 1.74 & 0.48 \\
paratype MB.C.18694.6 & 11.0 & 7.1 & 5.0 & 3.2 & 2.6 & 0.65 & 1.42 & 0.29 & 1.71 & 0.48 \\
paratype MB.C.18694.2 & 10.9 & 7.5 & 4.4 & 2.8 & - & 0.69 & 1.71 & 0.26 & - & - \\
\hline
\end{tabular}

Table 42. Suture line proportions (Fig. 37B) for Pachybollandoceras repens n. sp.

\begin{tabular}{llllllll}
\hline specimen & at dm & EL w/d & EL/VLS & EL/AL & MS h & VLS w/h & remarks \\
\hline holotype MB.C.18694.1 & $17.2 \mathrm{~mm}$ & 0.59 & 0.70 & 1.20 & 0.17 & 0.85 & flanks of E lobe slightly sinuous \\
\hline
\end{tabular}



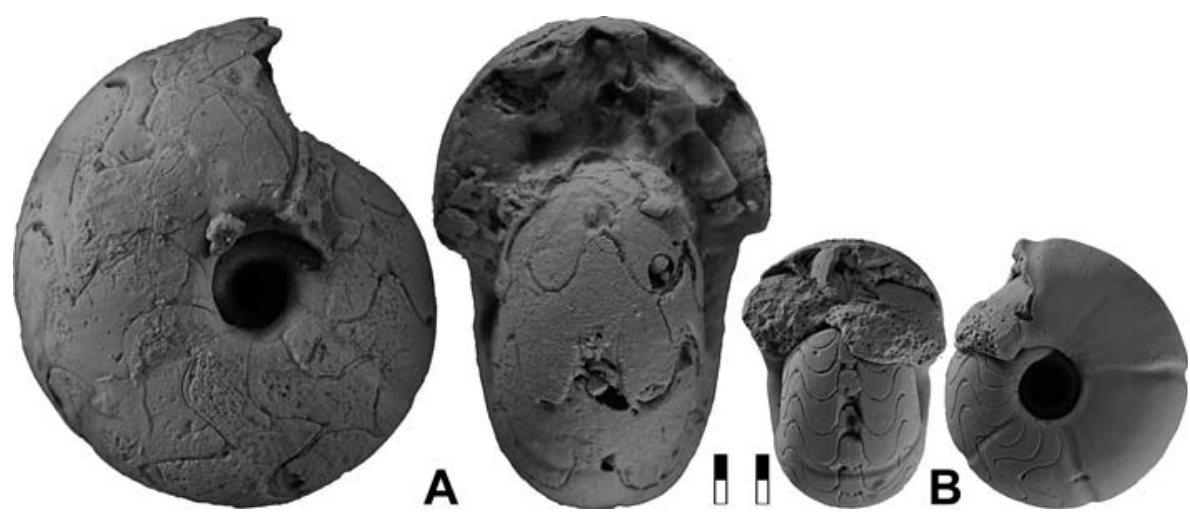

Figure 36. Pachybollandoceras repens n. sp. from locality TIM-C8; all $\times 2.5$. A. Holotype MB.C.18694.1. B. Paratype MB.C.18694.2.
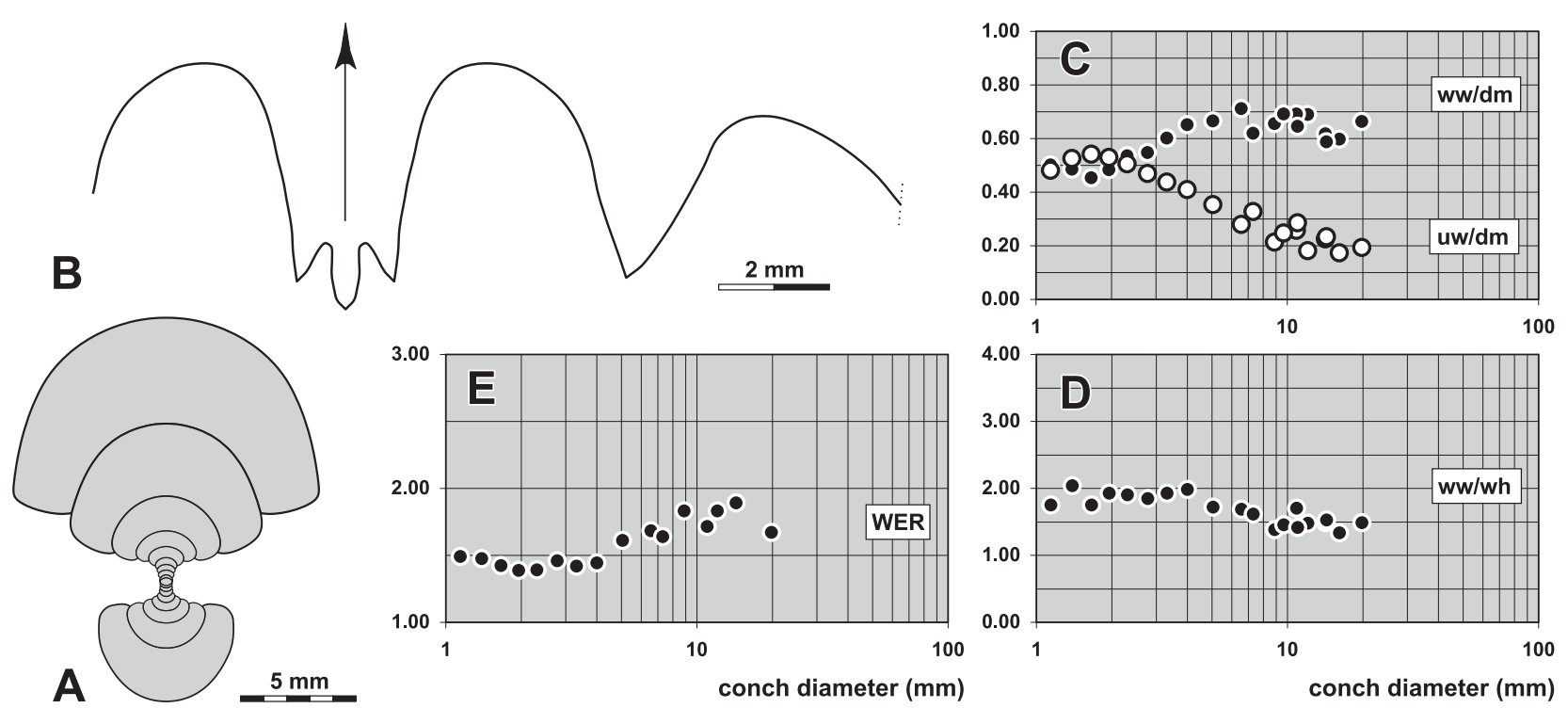

Figure 37. Pachybollandoceras repens n. sp. from locality TIM-C8. A. Cross section of paratype MB.C.18694.3; $\times 2.5$. B. Suture line of holotype MB.C.18694.1, at $17.2 \mathrm{~mm} \mathrm{dm}, 11.4 \mathrm{~mm} w w, 8.1 \mathrm{~mm}$ wh; $\times 6.0$. C-E. Ontogenetic development of the conch width index (ww/dm), umbilical width index (uw/dm), whorl width index (ww/wh), and whorl expansion rate (WER) of all available specimens.

Subfamily Bollanditinae n. subfam.

Subfamily definition. Maxigoniatitidae with a widely umbilicate juvenile and intermediate stage with a moderately to very strongly depressed whorl cross section. Ornament with almost linear, rather coarse growth lines. Suture line with V-shaped external lobe, flanks of the external lobe strongly sinuous in the early forms, sinuosity disappears in the advanced forms.

Included genera.

Bollandites Bisat, 1952

Gourarites n. gen.

Semibollandites n. gen.

Timimounia n. gen.

Discussion. The new subfamily represents a side branch of the family Maxigoniatitidae, in which the morphological evolution includes significant widening of the umbilicus and the lowering of the aperture causing very strongly depressed whorl cross sections. The suture line shows the transformation of the external lobe, from strongly sinuous flanks to concavely incurved flanks.

\section{Gourarites n. gen.}

Derivation of name. After the region of Gourara.

Type species. Gourarites hagarkarim n. sp.

Genus definition. Genus of the subfamily Bollanditinae with major ontogenetic changes of conch morphology (Figs 13, 38); adult conch discoidal with rapidly expanding whorls (WER above 2.10 in stages with a conch diameter larger than $10 \mathrm{~mm}$ ); juvenile whorls with very broad 
crescent-shaped whorl cross section; umbilicus wide to very wide in juveniles and narrow or almost closed in the adult stage; sudden closure of the umbilicus by strong whorl overlap. Steinkern with constrictions parallel to the growth lines. Suture line with very narrow to narrow, Vshaped external lobe with gently sinuous, slightly diverging flanks; secondary prongs of the external lobe hook-shaped; median saddle very low or low; ventrolateral saddle usually broadly rounded; adventive lobe V-shaped, often much shallower than the external lobe.

Included species.

hagaraswad: Gourarites hagaraswad n. sp.: Gourara, Algeria.

hagarkarim: Gourarites hagarkarim n. sp.: Gourara, Algeria.

mustari: Gourarites mustari n. sp.: Gourara, Algeria.

zuhal: Gourarites zuhal n. sp.: Gourara, Algeria.

Discussion. Gourarites differs from Bollandites and Timimounia in the strongly sinuous flanks of the external lobe and from Semibollandites in the much less widely umbilicate juvenile stage.
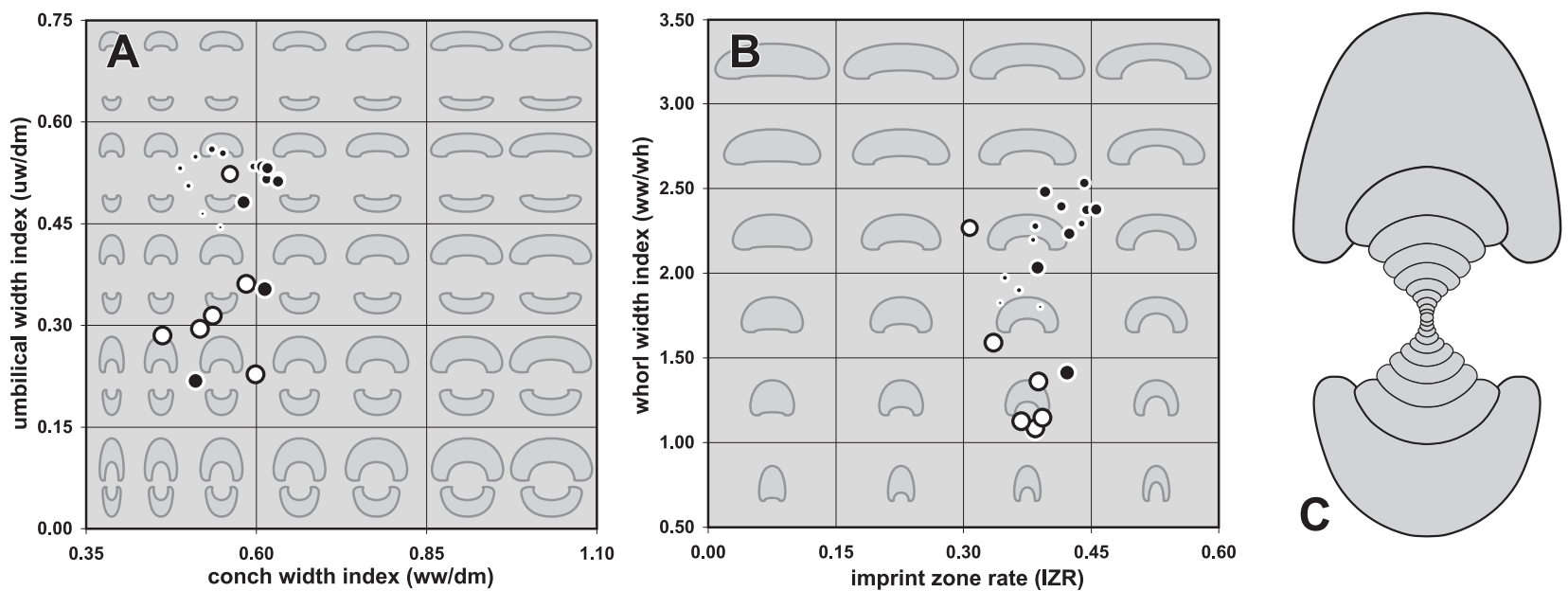

Figure 38. Ontogenetic trajectories of Gourarites, exemplified for G. hagarkarim n. sp. from locality TIM-C8. A. Ontogenetic development of the conch width index (ww/dm) and umbilical width index (uw/dm). B. Ontogenetic development of the imprint zone rate $($ IZR) and whorl width index (ww/wh). C. Cross section of paratype MB.C.18696.6; $\times 2.5$. [Black dots represent ontogenetic stages of cross section MB.C.18696.6, white dots represent the reference specimens (Tab. 47).]

\section{Gourarites hagaraswad n. sp.}

Figures 39, 40

Derivation of name. From the Arabic hagar aswad = black stone; referring to the limonitic preservation.

Holotype. Specimen MB.C.18695.1, illustrated in Figure Fig. 39A.

Type locality and horizon. Sebkha de Timimoun, locality TIM-C8 (13.3 km west of Timimoun, Algeria); Upper Bollandoceras-Bollandites Assemblage.

Material. 53 specimens, conch diameter between 9 and $25 \mathrm{~mm}$.

Diagnosis. Gourarites with major ontogenetic changes of conch geometry: conch evolute in the early juvenile stage (1.5-4 mm $\mathrm{dm})$ and subevolute or subinvolute at $20 \mathrm{~mm} \mathrm{dm}$; conch thickly discoidal in the early juvenile stage and thickly discoidal to thinly pachyconic in larger stages $(4-20 \mathrm{~mm} \mathrm{dm})$; aperture very low in juveniles $(2-8 \mathrm{~mm} \mathrm{dm})$ and then rapidly increasing (moderately high to high at $20 \mathrm{~mm} \mathrm{dm}$ ); umbilical margin rounded in juveniles and subangular in later stages. Steinkern with shallow, slightly biconvex constrictions and traces of biconvex growth lines. Suture line with narrow, slightly diverging external lobe with strongly sinuous flanks and very low to low median saddle; ventrolateral saddle broadly rounded; small adventive lobe V-shaped, symmetric.

Table 43. Conch ontogeny (Figs 40A, B, E-G) of Gourarites hagaraswad n. sp.

\begin{tabular}{|c|c|c|c|}
\hline $\mathrm{dm}$ & conch shape & whorl cross section shape & aperture \\
\hline $2 \mathrm{~mm}$ & $\begin{array}{l}\text { thickly discoidal; evolute } \\
(\mathrm{ww} / \mathrm{dm}=0.50-0.55 ; \mathrm{uw} / \mathrm{dm}=0.50-0.55)\end{array}$ & $\begin{array}{l}\text { moderately to strongly depressed; strongly embracing } \\
(\mathrm{ww} / \mathrm{wh}=1.75-2.20 ; \mathrm{IZR}=0.33-0.40)\end{array}$ & $\begin{array}{l}\text { very low } \\
(\text { WER }=1.40-1.50)\end{array}$ \\
\hline $8 \mathrm{~mm}$ & $\begin{array}{l}\text { thinly pachyconic; subevolute } \\
(\mathrm{ww} / \mathrm{dm}=0.60-0.70 ; \mathrm{uw} / \mathrm{dm}=0.35-0.45)\end{array}$ & $\begin{array}{l}\text { moderately to strongly depressed; strongly to very } \\
\text { strongly embracing } \\
\text { (ww/wh }=1.80-2.10 ; \mathrm{IZR}=0.40-0.48 \text { ) }\end{array}$ & $\begin{array}{l}\text { very low to low } \\
\text { (WER }=1.40-1.60)\end{array}$ \\
\hline $20 \mathrm{~mm}$ & $\begin{array}{l}\text { thickly discoidal; subinvolute } \\
(\mathrm{ww} / \mathrm{dm}=0.50-0.60 ; \mathrm{uw} / \mathrm{dm}=0.18-0.28)\end{array}$ & $\begin{array}{l}\text { weakly to moderately depressed; strongly embracing } \\
(\mathrm{ww} / \mathrm{wh}=1.10-1.60 ; \mathrm{IZR}=0.30-0.40)\end{array}$ & $\begin{array}{l}\text { moderate to high } \\
\text { (WER }=1.80-2.15)\end{array}$ \\
\hline
\end{tabular}


Table 44. Conch dimensions (in $\mathrm{mm}$ ) and proportions for reference specimens of Gourarites hagaraswad $\mathrm{n}$. sp.

\begin{tabular}{lcrcccccccc}
\hline & $\mathrm{dm}$ & ww & wh & uw & ah & ww/dm & ww/wh & uw/dm & WER & IZR \\
\hline holotype MB.C.18695.1 & 19.6 & 9.9 & 9.0 & 5.1 & 5.4 & 0.50 & 1.10 & 0.26 & 1.90 & 0.40 \\
paratype MB.C.18695.6 & 16.9 & 10.9 & 7.3 & 4.4 & 4.2 & 0.65 & 1.50 & 0.26 & 1.76 & 0.43 \\
paratype MB.C.18695.7 & 15.5 & 9.8 & 6.3 & 4.2 & 3.7 & 0.63 & 1.56 & 0.27 & 1.74 & 0.40 \\
paratype MB.C.18695.2 & 13.6 & 7.2 & 5.2 & 5.2 & 3.3 & 0.53 & 1.37 & 0.38 & 1.73 & 0.38 \\
paratype MB.C.18695.8 & 13.4 & 8.6 & 6.6 & 3.5 & 4.0 & 0.64 & 1.30 & 0.26 & 2.03 & 0.39 \\
paratype MB.C.18695.3 & 10.9 & 6.4 & 3.8 & 4.1 & 2.5 & 0.59 & 1.70 & 0.37 & 1.69 & 0.34 \\
\hline
\end{tabular}

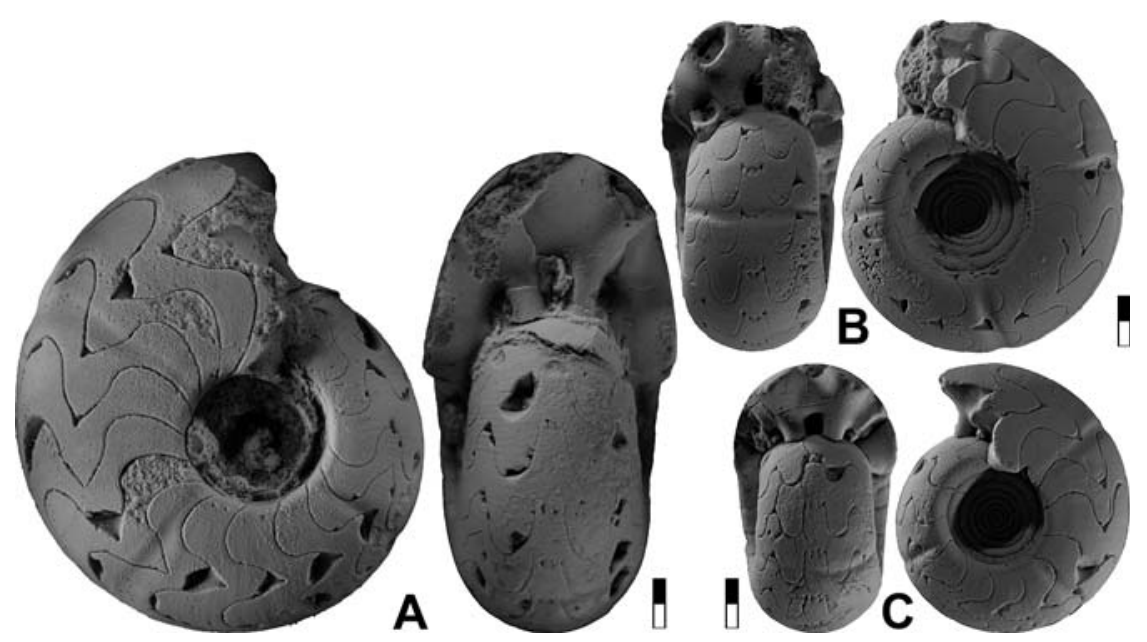

Figure 39. Gourarites hagaraswad n. sp. from locality TIM-C8; all $\times 2.5$. A. Holotype MB.C.18695.1. B. Paratype MB.C.18695.2. C. Paratype MB.C.18695.3.
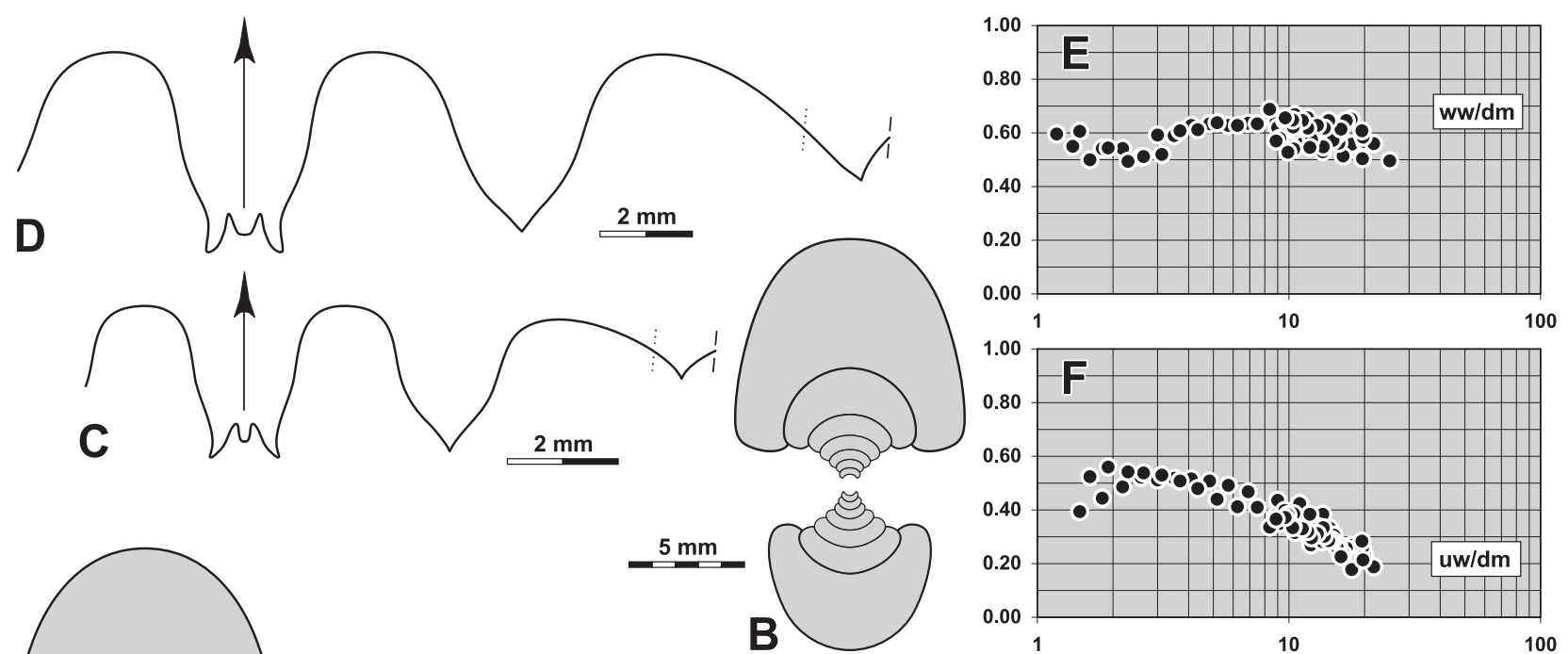
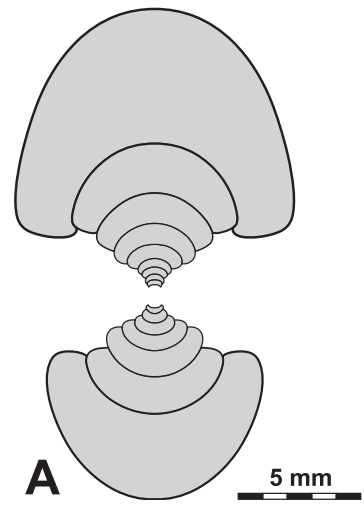
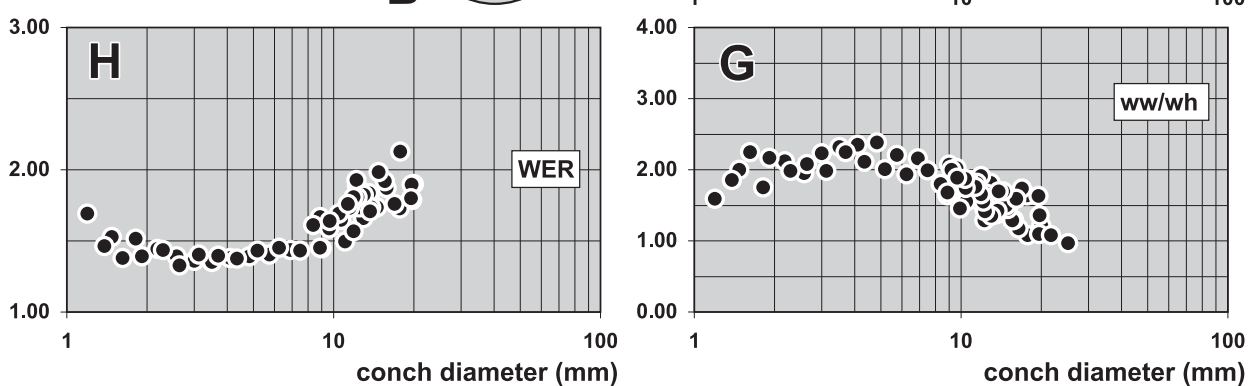

Figure 40. Gourarites hagaraswad n. sp. from locality TIM-C8. A. Cross section of paratype MB.C.18695.4; $\times 2.5$. B. Cross section of paratype MB.C.18695.5; $\times 2.5$. C. Suture line of paratype MB.C.18695.2, at $13.1 \mathrm{~mm} \mathrm{dm}, 7.3 \mathrm{~mm}$ ww; $\times 6.0$. D. Suture line of holotype MB.C.18695.1, at $18.5 \mathrm{~mm} \mathrm{dm}, 10.0 \mathrm{~mm}$ ww; $\times 5.0$. E-H. Ontogenetic development of the conch width index (ww/ $\mathrm{dm}$ ), umbilical width index (uw/dm), whorl width index (ww/wh), and whorl expansion rate (WER) of all available specimens. 
Table 45. Suture line proportions (Figs 40C, D) for Gourarites hagaraswad n. sp.

\begin{tabular}{llllllll}
\hline specimen & at dm & EL w/d & EL/VLS & EL/AL & MS h & VLS w/h & remarks \\
\hline holotype MB.C.18695.1 & $18.5 \mathrm{~mm}$ & 0.62 & 0.76 & 1.01 & 0.19 & 0.82 & \\
paratype MB.C.18695.2 & $13.1 \mathrm{~mm}$ & 0.65 & 0.90 & 1.02 & 0.22 & 0.72 & A lobe almost as deep as E lobe \\
\hline
\end{tabular}

Discussion. Gourarites hagaraswad has a morphological position between Bollandoceras mirrih (which possesses a shorter evolute juvenile stage; see above) and G. hagarkarim (with a longer evolute juvenile stage). G. hagarkarim in particular, is very similar, and this species is only clearly separable when the ontogeny of the umbilicus is studied. In $G$. hagaraswad, the uw/dm ratio begins to decrease already in a very early growth stage (at $2-3 \mathrm{~mm}$ $\mathrm{dm}$ ), whereas in G. hagarkarim the uw/dm ratio remains high (around 0.50) until $10 \mathrm{~mm}$ conch diameter.

\section{Gourarites hagarkarim n. sp.}

Figures 41, 42

Derivation of name. From the Arabic hagar karim = noble stone.

Holotype. Specimen MB.C.18696.1, illustrated in Figure 41B.

Type locality and horizon. Sebkha de Timimoun, locality TIM-C8 (13.3 km west of Timimoun, Algeria); Upper Bollandoceras-Bollandites Assemblage.

Material. 141 specimens, conch diameter between 9 and $23 \mathrm{~mm}$.

Diagnosis. Gourarites with major ontogenetic changes of conch geometry: conch evolute in the juvenile and intermediate stage (1.5-9 $\mathrm{mm} \mathrm{dm})$ and then becoming subinvolute to subevolute at $20 \mathrm{~mm} \mathrm{dm}$; conch thickly discoidal in the early juvenile stage and thickly discoidal to thinly pachyconic in larger stages; aperture very low in juveniles $(2-10 \mathrm{~mm} \mathrm{dm}$ ) and then rapidly increasing (moderately high to high at $20 \mathrm{~mm} \mathrm{dm}$ );
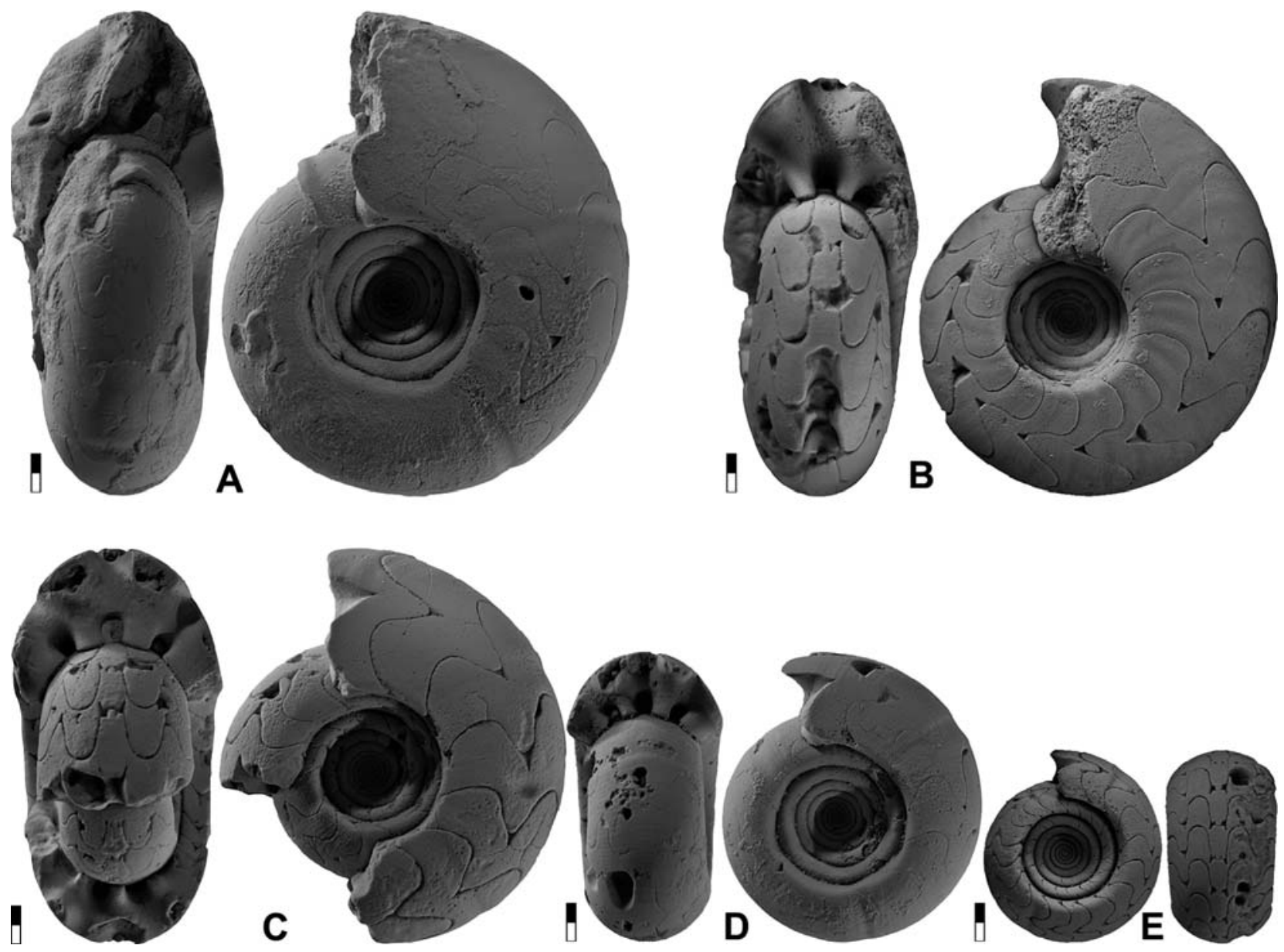

Figure 41. Gourarites hagarkarim n. sp. from locality TIM-C8; all ×2.5. A. Paratype MB.C.18696.2. B. Holotype MB.C.18696.1. C. Paratype MB.C.18696.3. D. Paratype MB.C.18696.4. E. Paratype MB.C.18696.5. 
umbilical margin rounded in juveniles and subangular in later stages. Steinkern with shallow, slightly biconvex constrictions and traces of biconvex growth lines. Suture line with narrow, slightly diverging external lobe with strongly sinuous flanks and low median saddle; ventrolateral saddle broadly rounded; small adventive lobe V-shaped, symmetric.

Table 46. Conch ontogeny (Figs 42A-E, H-K) of Gourarites hagarkarim n. sp.

\begin{tabular}{|c|c|c|c|}
\hline$d m$ & conch shape & whorl cross section shape & aperture \\
\hline $2 \mathrm{~mm}$ & $\begin{array}{l}\text { thinly to thickly discoidal; evolute } \\
\text { (ww/dm }=0.45-0.60 ; \mathrm{uw} / \mathrm{dm}=0.50-0.55 \text { ) }\end{array}$ & $\begin{array}{l}\text { moderately to strongly depressed; strongly embracing } \\
\text { (ww/wh }=1.75-2.25 ; \mathrm{IZR}=0.35-0.45 \text { ) }\end{array}$ & $\begin{array}{l}\text { very low } \\
(\mathrm{WER}=1.35-1.45)\end{array}$ \\
\hline $8 \mathrm{~mm}$ & $\begin{array}{l}\text { thickly discoidal to thinly pachyconic; } \\
\text { evolute } \\
\text { (ww/dm }=0.55-0.65 ; \mathrm{uw} / \mathrm{dm}=0.45-0.55 \text { ) }\end{array}$ & $\begin{array}{l}\text { strongly depressed; strongly to very strongly embracing } \\
(\mathrm{ww} / \mathrm{wh}=2.00-2.50 ; \mathrm{IZR}=0.40-0.50)\end{array}$ & $\begin{array}{l}\text { very low } \\
(\mathrm{WER}=1.35-1.50)\end{array}$ \\
\hline $20 \mathrm{~mm}$ & $\begin{array}{l}\text { thickly discoidal; subinvolute to subevolute } \\
\text { (ww/dm }=0.50-0.60 ; u w / d m=0.25-0.35)\end{array}$ & $\begin{array}{l}\text { weakly to moderately depressed; strongly embracing } \\
(\mathrm{ww} / \mathrm{wh}=1.10-1.80 ; \mathrm{IZR}=0.33-0.43 \text { ) }\end{array}$ & $\begin{array}{l}\text { moderate to high } \\
(\mathrm{WER}=1.75-2.15)\end{array}$ \\
\hline
\end{tabular}
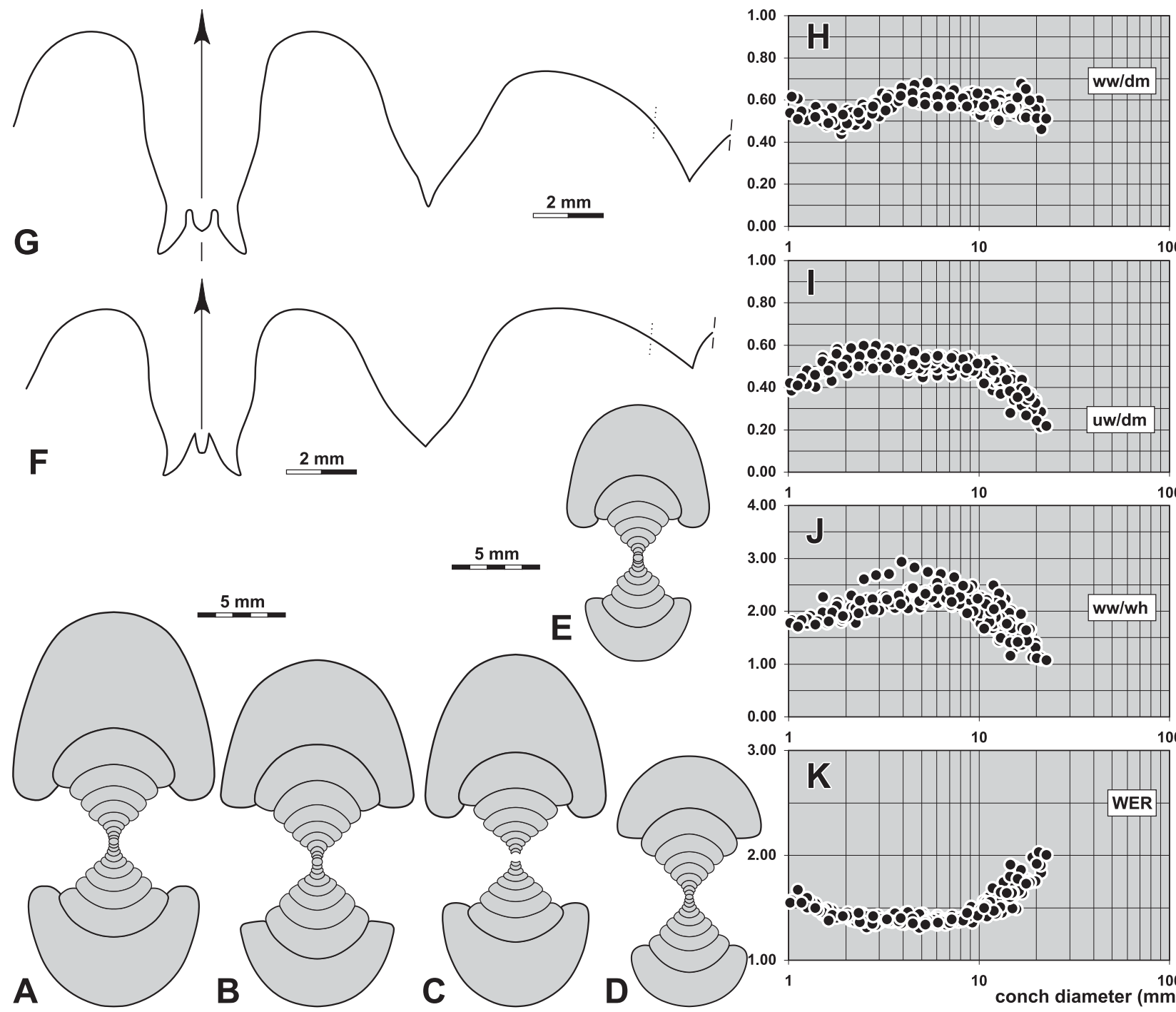

$5 \mathrm{~mm}$

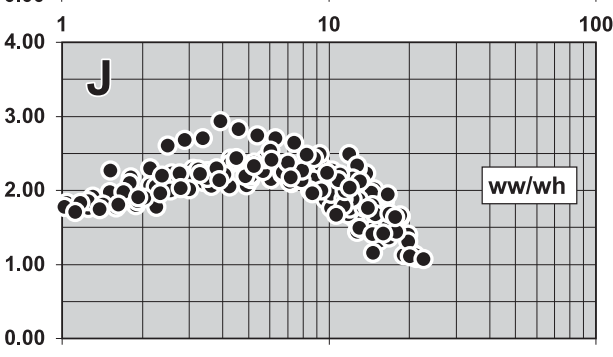

Figure 42. Gourarites hagarkarim n. sp. from locality TIM-C8. A. Cross section of paratype MB.C.18696.6; $\times 2.5$. B. Cross section of paratype MB.C. $18696.7 ; \times 2.5$. C. Cross section of paratype MB.C.18696.8; $\times 2.5$. D. Cross section of paratype MB.C.18696.9; $\times 2.5$. E. Cross section of paratype MB.C. $18696.10 ; \times 2.5$. F. Suture line of paratype MB.C.18696.6, at $20.0 \mathrm{~mm} \mathrm{dm}, 11.5 \mathrm{~mm}$ ww; $\times$ 6.0. G. Suture line of paratype MB.C.18696.11, at $21.0 \mathrm{~mm} \mathrm{dm}, 11.1 \mathrm{~mm} w w, 11.3 \mathrm{~mm} \mathrm{wh} \times 5.0$. H-K. Ontogenetic development of the conch width index (ww/dm), umbilical width index (uw/dm), whorl width index (ww/wh), and whorl expansion rate (WER) of all available specimens. 
Table 47. Conch dimensions (in $\mathrm{mm}$ ) and proportions for reference specimens of Gourarites hagarkarim $\mathrm{n}$. $\mathrm{sp}$.

\begin{tabular}{lcrrrrrrrrr}
\hline & dm & ww & wh & uw & ah & ww/dm & ww/wh & uw/dm & WER & IZR \\
\hline paratype MB.C.18696.2 & 25.3 & 11.1 & 11.3 & 8.4 & 6.9 & 0.44 & 0.98 & 0.33 & 1.89 & 0.39 \\
holotype MB.C.18696.1 & 21.2 & 9.8 & 9.0 & 6.1 & 5.6 & 0.46 & 1.09 & 0.29 & 1.83 & 0.38 \\
paratype MB.C.18696.3 & 21.0 & 10.7 & 7.7 & 7.8 & 4.5 & 0.51 & 1.39 & 0.37 & 1.62 & 0.42 \\
paratype MB.C.18696.13 & 20.6 & 12.3 & 10.7 & 4.7 & 6.5 & 0.60 & 1.15 & 0.23 & 2.13 & 0.39 \\
paratype MB.C.18696.12 & 19.0 & 9.8 & 8.7 & 5.6 & 5.5 & 0.52 & 1.13 & 0.30 & 1.98 & 0.37 \\
paratype MB.C.18696.15 & 17.9 & 10.5 & 6.6 & 6.5 & 4.4 & 0.59 & 1.59 & 0.36 & 1.75 & 0.34 \\
paratype MB.C.18696.14 & 16.7 & 9.0 & 6.6 & 5.3 & 4.0 & 0.54 & 1.36 & 0.31 & 1.73 & 0.39 \\
paratype MB.C.18696.4 & 15.5 & 8.3 & 4.9 & 7.4 & 3.2 & 0.53 & 1.68 & 0.48 & 1.59 & 0.35 \\
paratype MB.C.18696.5 & 10.3 & 5.8 & 2.5 & 5.4 & 1.8 & 0.56 & 2.27 & 0.52 & 1.46 & 0.31 \\
\hline
\end{tabular}

Table 48. Suture line proportions (Figs 42F, G) for Gourarites hagarkarim n. sp.

\begin{tabular}{lllllll}
\hline specimen & at dm & EL w/d & EL/NLS & EL/AL & MS h & VLS w/h \\
\hline paratype MB.C.18696.11 & $21.0 \mathrm{~mm}$ & 0.50 & 0.80 & 1.13 & 0.20 & 0.63 \\
paratype MB.C.18696.6 & $20.0 \mathrm{~mm}$ & 0.62 & 0.82 & 1.00 & 0.25 & 0.75 \\
\hline
\end{tabular}

Discussion. Gourarites hagarkarim is similar to G. hagaraswad but differs in the longer widely umbilicate ontogeny. In G. hagaraswad, the uw/dm ratio begins to decrease already at a very early growth stage $(2-3 \mathrm{~mm} \mathrm{dm})$, whereas in G. hagarkarim the uw/dm ratio remains high (around 0.50 ) until reaching a conch diameter of $10 \mathrm{~mm}$. Another distinguishing character is the strong whorl overlap in G. hagarkarim, where the umbilicus is closing at 12-14 mm conch diameter.

The two other co-occurring species G. mustari and G. zuhal differ in their wider whorl cross sections in the juvenile and intermediate stages, visible in the ww/wh diagrams. In G. hagarkarim, the ww/wh value usually does not exceed 2.50, whereas it ranges, in G. mustari and G. zuhal, between 2.50 and 3.50 .

\section{Gourarites mustari n. sp.}

Figures 43, 44

Derivation of name. From the Arabic mustari = Jupiter.

Holotype. Specimen MB.C.18697.1, illustrated in Figure 43A.

Type locality and horizon. Sebkha de Timimoun, locality TIM-C8 (13.3 km west of Timimoun, Algeria); Upper Bollandoceras-Bollandites Assemblage.

Material. 26 specimens, conch diameter between 12 and $31 \mathrm{~mm}$.

Diagnosis. Gourarites with major ontogenetic changes of conch geometry: conch evolute in the juvenile and intermediate stage (1.5-9 mm $\mathrm{dm}$ ) and then becoming subinvolute at $20 \mathrm{~mm} \mathrm{dm}$; conch thickly discoidal in the early juvenile stage and thinly to thickly pachyconic in larger stages with a trend towards a thickly discoidal conch in the adult stage; aperture very low in juveniles (2-8 mm dm) and then rapidly increasing (moderately high to high at $20 \mathrm{~mm} \mathrm{dm}$ ); umbilical margin rounded in juveniles and subangular or angular in later stages. Steinkern with shallow, slightly biconvex constrictions and traces of biconvex growth lines. Suture line with narrow, slightly diverging external lobe with moderately sinuous flanks and low median saddle; ventrolateral saddle broadly rounded; small adventive lobe V-shaped, slightly asymmetric.

Table 49. Conch ontogeny (Figs 44A-D, G-J) of Gourarites mustari n. sp.

\begin{tabular}{|c|c|c|c|}
\hline$d m$ & conch shape & whorl cross section shape & aperture \\
\hline $2 \mathrm{~mm}$ & $\begin{array}{l}\text { thickly discoidal to thinly pachyconic; evolute } \\
\text { (ww/dm }=0.50-0.65 ; u w / d m=0.50-0.60)\end{array}$ & $\begin{array}{l}\text { strongly to very strongly depressed; strongly embracing } \\
\text { (ww/wh }=2.20-2.70 ; \mathrm{IZR}=0.30-0.40 \text { ) }\end{array}$ & $\begin{array}{l}\text { very low } \\
(\mathrm{WER}=1.30-1.50)\end{array}$ \\
\hline $8 \mathrm{~mm}$ & $\begin{array}{l}\text { thinly to thickly pachyconic; evolute } \\
\text { (ww/dm }=0.60-0.75 ; u w / d m=0.45-0.55 \text { ) }\end{array}$ & $\begin{array}{l}\text { strongly to very strongly depressed; strongly embracing } \\
\text { (ww/wh }=2.00-2.70 ; \mathrm{IZR}=0.35-0.45)\end{array}$ & $\begin{array}{l}\text { very low } \\
(\mathrm{WER}=1.40-1.50)\end{array}$ \\
\hline 20 mm & $\begin{array}{l}\text { thickly discoidal; subinvolute } \\
(\mathrm{ww} / \mathrm{dm}=0.55-0.60 ; \mathrm{uw} / \mathrm{dm}=0.18-0.28)\end{array}$ & $\begin{array}{l}\text { weakly depressed; strongly embracing } \\
(\mathrm{ww} / \mathrm{wh}=1.00-1.50 ; \mathrm{IZR}=0.35-0.45)\end{array}$ & $\begin{array}{l}\text { moderate to high } \\
(\mathrm{WER}=1.75-2.15)\end{array}$ \\
\hline
\end{tabular}



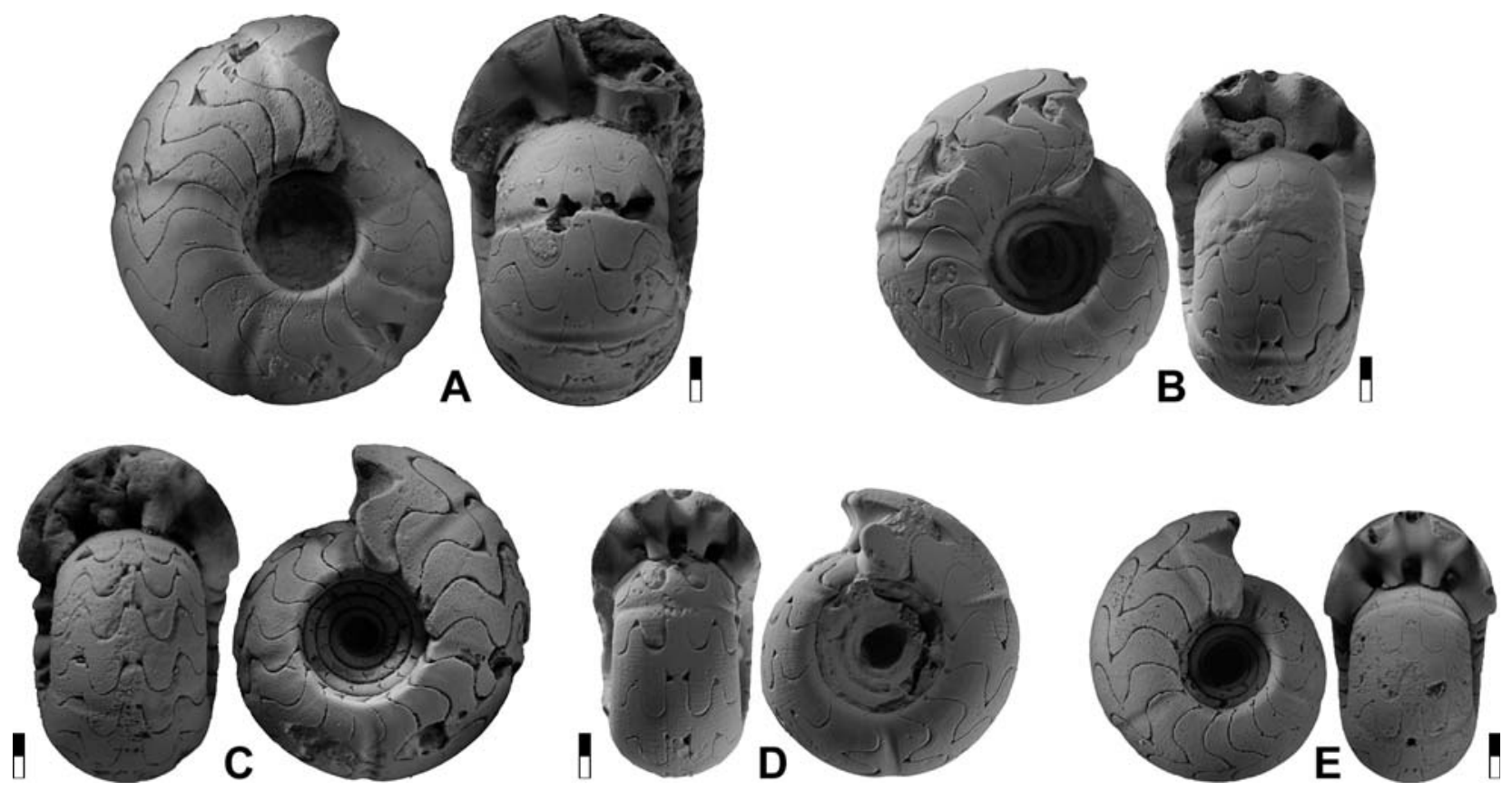

Figure 43. Gourarites mustari n. sp. from locality TIM-C8; all $\times 2.5$. A. Holotype MB.C.18697.1. B. Paratype MB.C.18697.2. C. Paratype MB.C.18697.3. D. Paratype MB.C.18697.4. E. Paratype MB.C.18697.5.
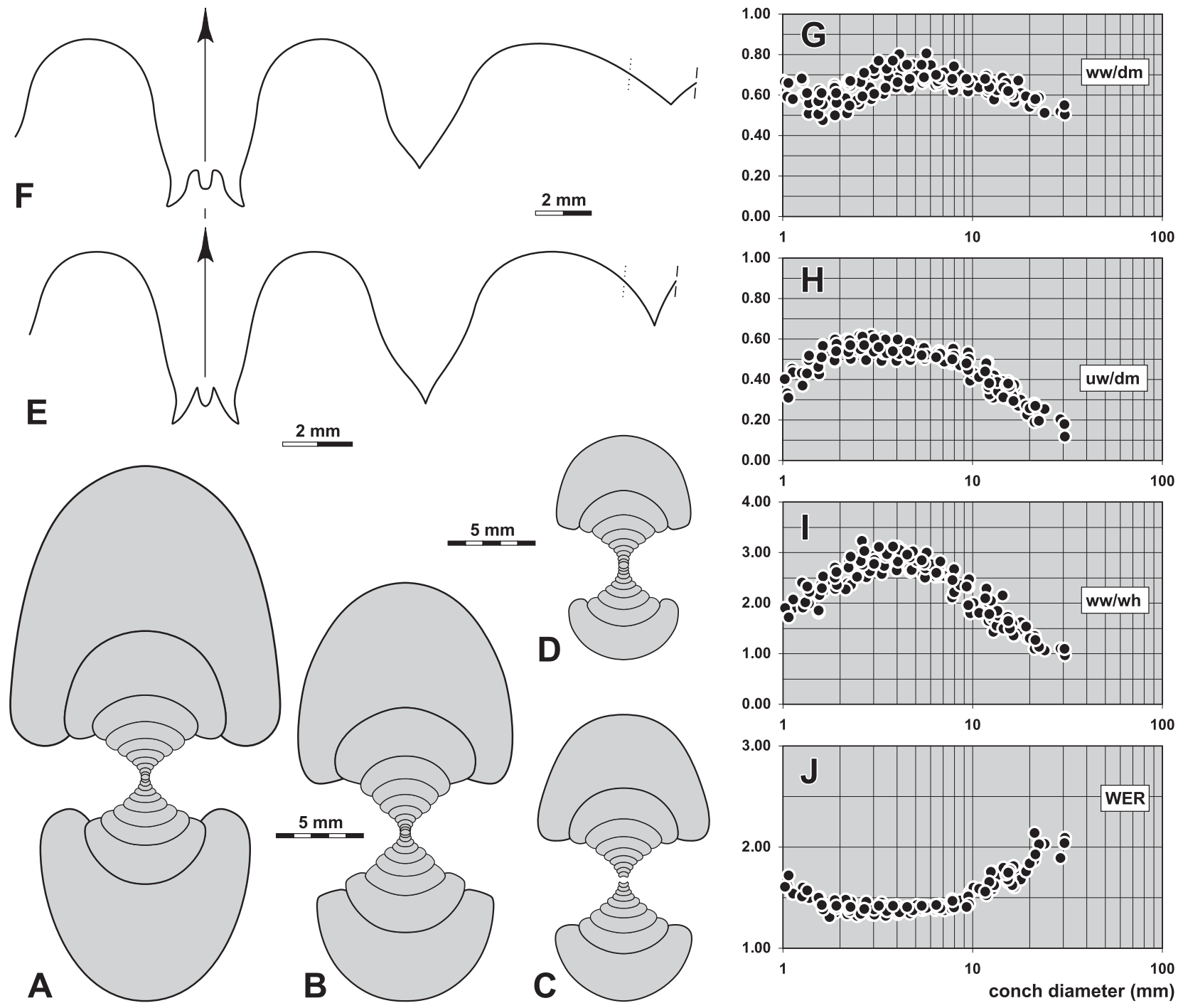
Table 50. Conch dimensions (in $\mathrm{mm}$ ) and proportions for reference specimens of Gourarites mustari n. sp.

\begin{tabular}{|c|c|c|c|c|c|c|c|c|c|c|}
\hline & $\mathrm{dm}$ & ww & wh & uw & ah & ww/dm & ww/wh & $\mathrm{uw} / \mathrm{dm}$ & WER & IZR \\
\hline paratype MB.C.18697.11 & 20.0 & 10.8 & 8.3 & 5.1 & 5.3 & 0.54 & 1.31 & 0.26 & 1.84 & 0.37 \\
\hline holotype MB.C.18697.1 & 17.9 & 10.9 & 6.7 & 5.4 & 4.1 & 0.61 & 1.63 & 0.30 & 1.68 & 0.39 \\
\hline paratype MB.C.18697.2 & 15.4 & 9.2 & 5.5 & 5.0 & 3.6 & 0.60 & 1.68 & 0.33 & 1.70 & 0.35 \\
\hline paratype MB.C.18697.3 & 15.3 & 9.8 & 5.7 & 5.4 & 3.5 & 0.64 & 1.73 & 0.35 & 1.68 & 0.38 \\
\hline paratype MB.C.18697.4 & 13.0 & 7.5 & 4.2 & 5.5 & 2.8 & 0.58 & 1.79 & 0.42 & 1.63 & 0.33 \\
\hline paratype MB.C.18697.5 & 12.3 & 7.7 & 4.6 & 4.0 & 2.7 & 0.63 & 1.67 & 0.33 & 1.64 & 0.41 \\
\hline
\end{tabular}

Table 51. Suture line proportions (Figs 44E, F) for Gourarites mustari n. sp.

\begin{tabular}{llllllll}
\hline specimen & at $\mathrm{dm}$ & EL w/d & EL/VLS & EL/AL & MS h & VLS w/h & remarks \\
\hline paratype MB.C.18697.9 & $22.0 \mathrm{~mm}$ & 0.60 & 0.76 & 1.30 & 0.22 & 0.79 & ventral flank of A lobe curved \\
paratype MB.C.18697.7 & $18.0 \mathrm{~mm}$ & 0.51 & 0.66 & 0.97 & 0.21 & 0.77 & \\
\hline
\end{tabular}

Discussion. Gourarites hagaraswad is a similar species with respect to conch ontogeny, but differs in the slender conch shape $(\mathrm{ww} / \mathrm{dm}=0.50-0.60$ at $10 \mathrm{~mm} \mathrm{dm})$ from $G$. mustari $(\mathrm{ww} / \mathrm{dm}=0.60-0.70$ at the same diameter). Better distinguishing characters can be seen in the development of the umbilicus. G. hagaraswad shows, already at $10 \mathrm{~mm} \mathrm{dm}$, a reduction of the uw/dm ratio to $0.30-0.40$, whereas this change occurs much later in G. mustari (at 15-18 mm).

G. hagarkarim and G. zuhal differ from G. mustari in the more rapidly closing umbilicus in the intermediate stage. Both species show very strong overlap of the whorls onto the umbilicus at about $15 \mathrm{~mm}$ conch diameter. G. zuhal has a much narrower external lobe than G. mustari.

\section{Gourarites zuhal n. sp.}

Figures 45, 46

Derivation of name. From the Arabic zuhal = Saturn.

Holotype. Specimen MB.C.18698.1, illustrated in Figure Fig. 45A.

Type locality and horizon. Sebkha de Timimoun, locality TIM-C8 (13.3 km west of Timimoun, Algeria); Upper Bollandoceras-Bollandites Assemblage.

Material. 34 specimens, conch diameter between 13 and $31 \mathrm{~mm}$.

Diagnosis. Gourarites with major ontogenetic changes of conch geometry: conch evolute in the juvenile and intermediate stage (from 1.5$12 \mathrm{~mm} \mathrm{dm}$ ) and then becoming subevolute at $20 \mathrm{~mm} \mathrm{dm}$; conch thickly discoidal in the early juvenile stage and thinly pachyconic in larger stages with a trend towards a thickly discoidal conch in the adult stage; aperture very low in juveniles $(2-12 \mathrm{~mm}$ dm) and then rapidly increasing (moderately high $20 \mathrm{~mm} \mathrm{dm}$ ); umbilical margin rounded in juveniles and subangular or angular in later stages; umbilicus rapidly becoming narrow by strong whorl overlap. Steinkern with shallow, slightly biconvex constrictions and traces of biconvex growth lines. Suture line with very narrow, slightly diverging external lobe with weakly sinuous flanks and low median saddle; ventrolateral saddle broadly rounded; adventive lobe V-shaped, almost symmetric.

Table 52. Conch ontogeny (Figs 46A-D, G-J) of Gourarites zuhal n. sp.

\begin{tabular}{|c|c|c|c|}
\hline $\mathrm{dm}$ & conch shape & whorl cross section shape & aperture \\
\hline $2 \mathrm{~mm}$ & $\begin{array}{l}\text { thinly pachyconic; evolute } \\
\text { (ww/dm }=0.60-0.70 ; u w / d m=0.50-0.60 \text { ) }\end{array}$ & $\begin{array}{l}\text { strongly to very strongly depressed; strongly embracing } \\
\text { (ww/wh }=2.30-3.00 ; \mathrm{IZR}=0.30-0.40 \text { ) }\end{array}$ & $\begin{array}{l}\text { very low } \\
(\mathrm{WER}=1.35-1.40)\end{array}$ \\
\hline $8 \mathrm{~mm}$ & $\begin{array}{l}\text { thinly pachyconic; evolute } \\
(\mathrm{ww} / \mathrm{dm}=0.65-0.70 ; \mathrm{uw} / \mathrm{dm}=0.55-0.60\end{array}$ & $\begin{array}{l}\text { very strongly to extremely depressed; } \\
\text { strongly embracing }(w w / w h=2.60-3.20 ; I Z R=0.35-0.45)\end{array}$ & $\begin{array}{l}\text { very low } \\
(\mathrm{WER}=1.35-1.45)\end{array}$ \\
\hline $20 \mathrm{~mm}$ & $\begin{array}{l}\text { thickly discoidal to thinly pachyconic; subevolute } \\
\text { (ww/dm }=0.50-0.65 ; \mathrm{uw} / \mathrm{dm}=0.30-0.40 \text { ) }\end{array}$ & $\begin{array}{l}\text { weakly to moderately depressed; strongly embracing } \\
\text { (ww/wh }=1.30-1.60 ; \mathrm{IZR}=0.35-0.45 \text { ) }\end{array}$ & $\begin{array}{l}\text { low to moderate } \\
(\mathrm{WER}=1.70-1.85)\end{array}$ \\
\hline
\end{tabular}

Figure 44. Gourarites mustari n. sp. from locality TIM-C8. A. Cross section of paratype MB.C.18697.6; × 2.5. B. Cross section of paratype MB.C.18697.7; ×2.5. C. Cross section of paratype MB.C.18697.8; 132.5. D. Cross section of paratype MB.C.18697.10; $\times 2.5$. E. Suture line of paratype MB.C.18697.7, at $18.0 \mathrm{~mm} \mathrm{dm}, 10.2 \mathrm{~mm}$ ww, $7.8 \mathrm{~mm}$ wh; $\times 5.0$. F. Suture line of paratype MB.C.18697.9, at $22.0 \mathrm{~mm} \mathrm{dm}, 13.4 \mathrm{~mm}$ ww, $11.7 \mathrm{~mm} \mathrm{wh} ; \times 4.0$. G-J. Ontogenetic development of the conch width index (ww/ $\mathrm{dm}$ ), umbilical width index (uw/dm), whorl width index (ww/wh), and whorl expansion rate (WER) of all available specimens. 

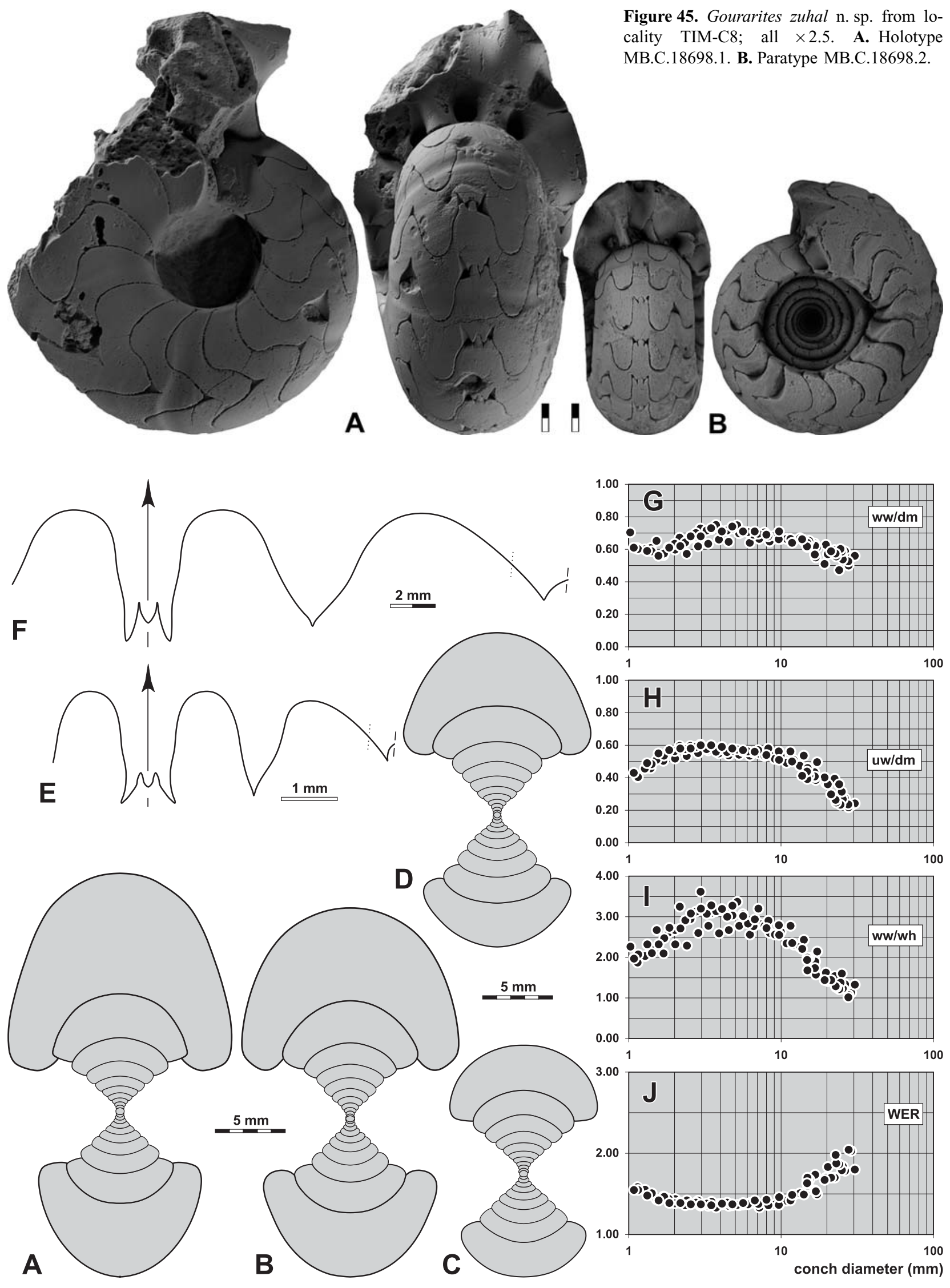

Figure 46. Gourarites zuhal n. sp. from locality TIM-C8. A. Cross section of paratype MB.C.18698.3; $\times 2.5$. B. Cross section of paratype MB.C.18698.4; $\times 2.5$. C. Cross section of paratype MB.C.18698.5; $\times 2.5$. D. Cross section of paratype MB.C.18698.6; $\times 2.5$. E. Suture line of paratype MB.C. 18698.5 , at $6.0 \mathrm{~mm} \mathrm{dm}, 4.1 \mathrm{~mm}$ ww, $2.0 \mathrm{~mm}$ wh; $\times 10.0$. F. Suture line of paratype MB.C.18698.4, at $25.0 \mathrm{~mm} \mathrm{dm}, 15.0 \mathrm{~mm}$ ww, $14.0 \mathrm{~mm}$ wh; $\times 4.0$. G-J. Ontogenetic development of the conch width index (ww/ $\mathrm{dm}$ ), umbilical width index (uw/dm), whorl width index (ww/wh), and whorl expansion rate (WER) of all available specimens. 
Table 54. Conch dimensions (in $\mathrm{mm}$ ) and proportions for reference specimens of Gourarites zuhal $\mathrm{n}$. sp.

\begin{tabular}{|c|c|c|c|c|c|c|c|c|c|c|}
\hline & $\mathrm{dm}$ & wW & wh & uw & ah & ww/dm & ww/wh & $\mathrm{uw} / \mathrm{dm}$ & WER & IZR \\
\hline holotype MB.C.18698.1 & 30.5 & 17.1 & 12.9 & 7.4 & 7.8 & 0.56 & 1.33 & 0.24 & 1.80 & 0.40 \\
\hline paratype MB.C.18698.9 & 27.8 & 13.9 & 13.0 & 6.1 & 8.4 & 0.50 & 1.07 & 0.22 & 2.04 & 0.36 \\
\hline paratype MB.C.18698.10 & 25.4 & 13.7 & 11.1 & 6.8 & 6.7 & 0.54 & 1.24 & 0.27 & 1.84 & 0.40 \\
\hline paratype MB.C.18698.7 & 25.1 & 14.7 & 9.2 & 7.9 & 6.4 & 0.59 & 1.60 & 0.31 & 1.79 & 0.31 \\
\hline paratype MB.C.18698.2 & 19.3 & 9.8 & 6.8 & 7.8 & 4.4 & 0.51 & 1.44 & 0.40 & 1.67 & 0.36 \\
\hline paratype MB.C.18698.8 & 19.0 & 10.5 & 5.8 & 8.5 & 3.8 & 0.55 & 1.82 & 0.44 & 1.56 & 0.34 \\
\hline
\end{tabular}

Table 54. Suture line proportions (Figs 46E, F) for Gourarites zuhal n. sp.

\begin{tabular}{llllllll}
\hline specimen & at dm & EL w/d & EL/VLS & EL/AL & MS h & VLS w/h & remarks \\
\hline paratype MB.C.18698.4 & $25.0 \mathrm{~mm}$ & 0.46 & 0.60 & 0.75 & 0.22 & 0.77 & A lobe symmetrically V-shaped \\
paratype MB.C.18698.5 & $6.0 \mathrm{~mm}$ & 0.47 & 0.80 & 1.30 & 0.24 & 0.59 & A lobe very narrow \\
\hline
\end{tabular}

Discussion. Gourarites zuhal differs from the similar G. mustari in the rapid decrease of the uw/dm ratio by remarkable whorl overlap in the intermediate stage at $14-18 \mathrm{~mm} \mathrm{dm}$. Another criterion to separate the two species is the narrower external lobe in G. zuhal, which has only 0.45 of the external lobe width, in contrast to 0.55 in G. mustari.

G. hagarkarim also shows strong whorl overlap onto the umbilicus, but differs in the shorter evolute ontogenetic stage, ending at about $8 \mathrm{~mm} \mathrm{dm}$ in G. hagarkarim and at $12 \mathrm{~mm}$ in G. zuhal. The narrower external lobe in G. zuhal is another distinguishing character.

\section{Semibollandites n. gen.}

Derivation of name. Reference to the genus Bollandites, which may be a descendent.

Type species. Semibollandites kamil n. sp.

Genus definition. Genus of the subfamily Bollanditinae with major ontogenetic changes of conch morphology (Fig. 47); adult conch pachyconic with slowly expanding whorls (WER less than 1.70 in stages larger than $10 \mathrm{~mm}$ conch diameter); conch evolute in juveniles and subevolute in the adult stage. Suture line with narrow, V-shaped external lobe with gently sinuous, diverging flanks; secondary prongs of the external lobe hook-shaped; median saddle usually very low; ventrolateral saddle narrowly to broadly rounded; adventive lobe V-shaped.

Included species.

varians: Bollandites varians Riley, 1996: 76. Lancashire.

kamil: Semibollandites kamil n. sp.: Gourara, Algeria.

pauculus: Semibollandites pauculus n. sp.: Gourara, Algeria.

qawiy: Semibollandites qawiy n. sp.: Gourara, Algeria.

? trevallynensis: Beyrichoceras trevallynense Brown, Campbell \& Roberts, 1964: 689. New South Wales.
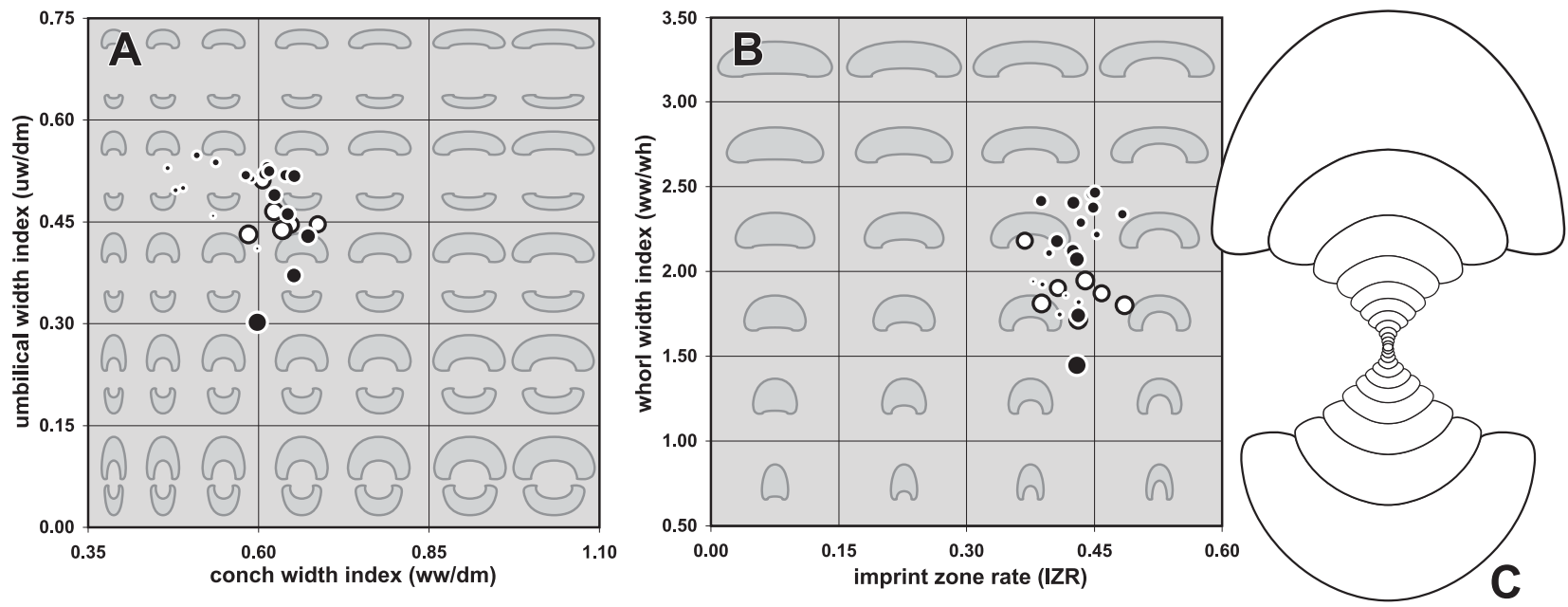

Figure 47. Ontogenetic trajectories of Semibollandites, exemplified for S. kamil n. sp. from locality TIM-B3. A. Ontogenetic development of the conch width index (ww/dm) and umbilical width index (uw/dm). B. Ontogenetic development of the imprint zone rate $(\mathrm{IZR})$ and whorl width index $(\mathrm{ww} / \mathrm{wh})$. C. Cross section of paratype MB.C.18699.5; $\times 2.5$. [Black dots represent ontogenetic stages of cross section MB.C.18699.5, white dots represent the reference specimens (Tab. 56).] 
Discussion. Semibollandites differs from Gourarites and Bollandites in the absence of adult narrowing of the uw/ $\mathrm{dm}$ ratio. Timimounia has an even wider umbilicus than Semibollandites; an adult narrowing of the umbilicus does not occur in that genus either. The main difference between the two genera is the shape of the external lobe, which is V-shaped in Semibollandites and nearly parallel-sided in Timimounia.

\section{Semibollandites kamil n. sp.}

Figures 48, 49

Derivation of name. From the Arabic al-kamil = the perfect.

Holotype. Specimen MB.C.18699.1, illustrated in Figure 48B.

Type locality and horizon. Sebkha de Timimoun, locality TIM-C8 (13.3 km west of Timimoun, Algeria); Upper Bollandoceras-Bollandites Assemblage.

Material. 37 specimens, conch diameter between 8 and $32 \mathrm{~mm}$.

Diagnosis. Semibollandites with moderate ontogenetic changes of conch geometry: conch evolute in the juvenile and preadult stage (1.5-13 mm dm) and subevolute at $20 \mathrm{~mm} \mathrm{dm}$; conch thickly discoidal in the early juvenile stage and thinly pachyconic in larger stages; aperture very low in the juvenile and preadult stage $(2-13 \mathrm{~mm} \mathrm{dm})$ and then slowly increasing; umbilical margin subangular in juveniles and subangular or angular in later stages. Steinkern with shallow, almost straight constrictions and traces of concavo-convex growth lines. Suture line with narrow, strongly diverging external lobe with slightly sinuous flanks and very low median saddle; ventrolateral saddle broadly rounded; adventive lobe V-shaped, asymmetric.

Table 55. Conch ontogeny (Figs 49A, B, E-H) of Semibollandites kamil n. sp.

\begin{tabular}{|c|c|c|c|}
\hline$d m$ & conch shape & whorl cross section shape & aperture \\
\hline $2 \mathrm{~mm}$ & $\begin{array}{l}\text { thickly discoidal; evolute } \\
(w w / d m=0.48-0.60 ; u w / d m=0.50-0.55)\end{array}$ & $\begin{array}{l}\text { moderately depressed; strongly embracing } \\
(\mathrm{ww} / \mathrm{wh}=1.70-2.00 ; \mathrm{IZR}=0.38-0.45)\end{array}$ & $\begin{array}{l}\text { very low } \\
(\mathrm{WER}=1.40-1.50)\end{array}$ \\
\hline $8 \mathrm{~mm}$ & $\begin{array}{l}\text { thinly pachyconic; evolute } \\
(\mathrm{ww} / \mathrm{dm}=0.60-0.65 ; \mathrm{uw} / \mathrm{dm}=0.50-0.56\end{array}$ & $\begin{array}{l}\text { strongly to very strongly depressed; strongly to very } \\
\text { strongly embracing ( } w w / w h=2.10-2.70 ; I Z R=0.35-0.50)\end{array}$ & $\begin{array}{l}\text { very low } \\
(\mathrm{WER}=1.30-1.40)\end{array}$ \\
\hline $20 \mathrm{~mm}$ & $\begin{array}{l}\text { thinly pachyconic; subevolute to evolute } \\
(\mathrm{ww} / \mathrm{dm}=0.60-0.70 ; \mathrm{uw} / \mathrm{dm}=0.35-0.50)\end{array}$ & $\begin{array}{l}\text { moderately to strongly depressed; strongly embracing } \\
\text { (ww/wh }=1.50-2.20 ; 1 \mathrm{ZR}=0.35-0.45 \text { ) }\end{array}$ & $\begin{array}{l}\text { very low to low } \\
(\mathrm{WER}=1.45-1.55)\end{array}$ \\
\hline
\end{tabular}

Table 56. Conch dimensions (in $\mathrm{mm}$ ) and proportions for reference specimens of Semibollandites kamil $\mathrm{n}$. sp.

\begin{tabular}{lllllllllll}
\hline & $\mathrm{dm}$ & ww & wh & uw & ah & ww/dm & ww/wh & uw/dm & WER & IZR \\
\hline paratype MB.C.18699.8 & 23.5 & 13.8 & 8.0 & 10.1 & 4.6 & 0.59 & 1.72 & 0.43 & 1.54 & 0.43 \\
paratype MB.C.18699.2 & 17.7 & 11.1 & 6.5 & 6.7 & 3.8 & 0.63 & 1.71 & 0.38 & 1.61 & 0.42 \\
paratype MB.C.18699.3 & 17.2 & 10.9 & 5.6 & 7.5 & 3.1 & 0.64 & 1.95 & 0.44 & 1.50 & 0.44 \\
holotype MB.C.18699.1 & 17.2 & 10.9 & 6.0 & 7.5 & 3.7 & 0.63 & 1.82 & 0.44 & 1.62 & 0.39 \\
paratype MB.C.18699.4 & 15.0 & 10.3 & 5.4 & 6.7 & 3.2 & 0.69 & 1.91 & 0.45 & 1.62 & 0.41 \\
paratype MB.C.18699.7 & 13.9 & 9.0 & 4.8 & 6.2 & 2.6 & 0.65 & 1.88 & 0.45 & 1.51 & 0.46 \\
paratype MB.C.18699.9 & 13.7 & 8.3 & 3.8 & 7.0 & 2.4 & 0.61 & 2.18 & 0.51 & 1.47 & 0.37
\end{tabular}

Table 57. Suture line proportions (Figs 49C, D) for Semibollandites kamil n. sp.

\begin{tabular}{llllllll}
\hline specimen & at dm & EL w/d & EL/VLS & EL/AL & MS h & VLS w/h & remarks \\
\hline paratype MB.C.18699.6 & c. $22.0 \mathrm{~mm}$ & 0.54 & 0.76 & 0.86 & 0.16 & 0.72 & A lobe with curved ventral flank \\
holotype MB.C.18699.1 & c. $20.0 \mathrm{~mm}$ & 0.54 & 0.72 & 0.80 & 0.17 & 0.75 & E lobe almost parallel-sided \\
\hline
\end{tabular}

Discussion. Semibollandites kamil differs from Timimounia timimounensis in the narrower umbilicus in the adult stage (uw/dm $=0.25-0.35$ at $25 \mathrm{~mm} \mathrm{dm}$ in $S$. kamil and more than 0.40 in T. timimounensis). This difference is caused by the ontogenetic reduction of the uw/dm ratio, which in $S$. kamil slowly begins at about $10 \mathrm{~mm}$ conch diameter and becomes more rapid at $16 \mathrm{~mm} \mathrm{dm}$, whereas this process is much slower in B. timimounensis.

T. lunula has a much wider umbilicus than $S$. kamil and also differs in the very wide, ventrally depressed whorl cross section. The other two species S. pauculus and S. qawiy show ontogenetic traits characterised by an increase of the uw/dm ratio, and are thus clearly separated from $S$. kamil.

Figure 49. Semibollandites kamil n. sp. from locality TIM-C8. A. Cross section of paratype MB.C.18699.5; $\times 2.5$. B. Cross section of paratype MB.C.18699.6; $\times 2.5$. C. Suture line of holotype MB.C.18699.1, at $15.0 \mathrm{~mm} \mathrm{dm}, 10.0 \mathrm{~mm} w w, 5.5 \mathrm{~mm}$ wh; $\times 6.0$. D. Suture line of paratype MB.C.18699.6, at $13.1 \mathrm{~mm}$ ww, $9.5 \mathrm{~mm}$ wh; $\times 5.0$. E-H. Ontogenetic development of the conch width index (ww/ $\mathrm{dm}$ ), umbilical width index (uw/dm), whorl width index (ww/wh), and whorl expansion rate (WER) of all available specimens. 

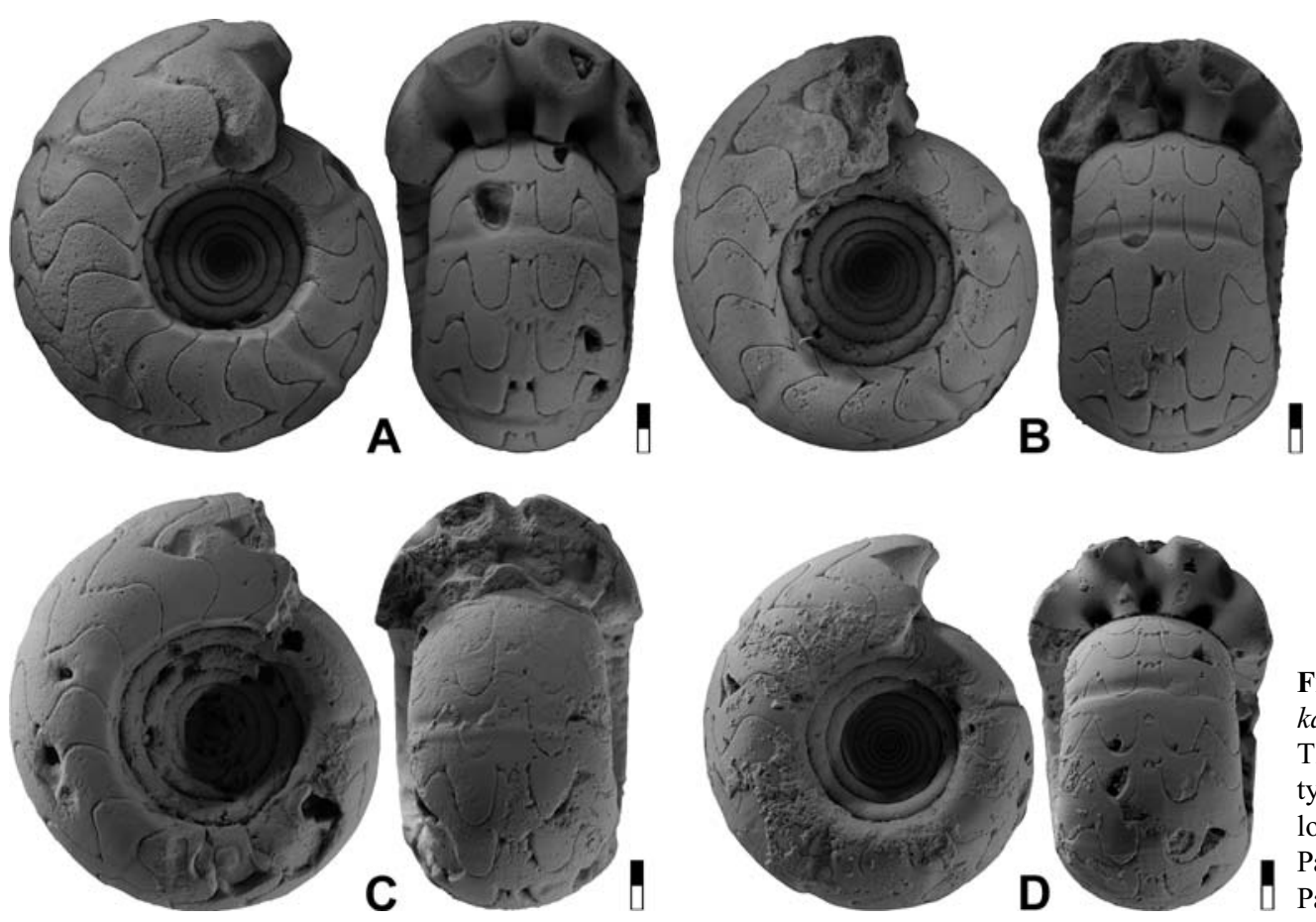

Figure 48. Semibollandites kamil n. sp. from locality TIM-C8; all $\times 2.5$. A. Paratype MB.C.18699.2. B. Holotype MB.C.18699.1. B.

Paratype MB.C.18699.3. C. Paratype MB.C.18699.4
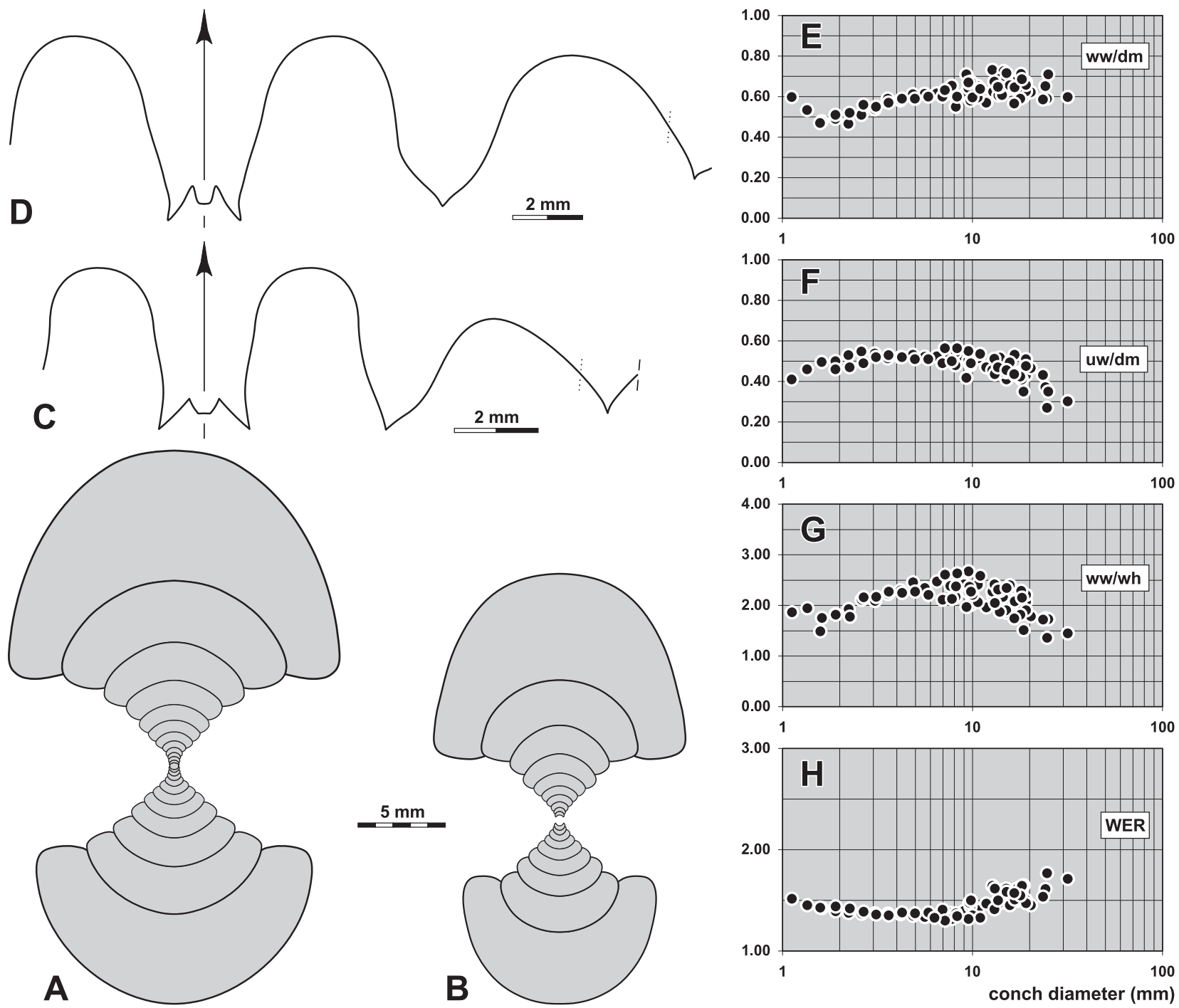


\section{Semibollandites pauculus n. sp.}

Figures 50, 51

Derivation of name. From Latin pauculus $=$ very few.

Holotype. Specimen MB.C.18700.1, illustrated in Figure 50A.

Type locality and horizon. Sebkha de Timimoun, locality TIM-C8 (13.3 km west of Timimoun, Algeria); Upper Bollandoceras-Bollandites Assemblage.

Material. Six specimens, conch diameter between 11 and $21 \mathrm{~mm}$.

Diagnosis. Semibollandites with major ontogenetic changes of conch geometry: conch evolute in the juvenile stage (from $1.5-4 \mathrm{~mm} \mathrm{dm}$ ) and then becoming subevolute at $20 \mathrm{~mm} \mathrm{dm}$; conch thickly discoidal in early juveniles and becoming in later stages pachyconic; aperture very low in juveniles $(2-6 \mathrm{~mm} \mathrm{dm})$ and then slowly increasing but still low at $20 \mathrm{~mm} \mathrm{dm}$; umbilical margin rounded in juveniles and subangular in later stages. Steinkern with shallow, slightly backwardly extending constrictions. Suture line with narrow, moderately to strongly diverging external lobe with almost straight flanks and a very low median saddle; ventrolateral saddle broadly rounded; adventive lobe V-shaped, symmetric with strongly convex flanks.

Table 58. Conch ontogeny (Figs 51A, B, E-H) of Semibollandites pauculus n. sp.

\begin{tabular}{|c|c|c|c|}
\hline $\mathrm{dm}$ & conch shape & whorl cross section shape & aperture \\
\hline $2 \mathrm{~mm}$ & $\begin{array}{l}\text { thickly discoidal; evolute } \\
(\mathrm{w} w / \mathrm{dm}=0.50-0.60 ; \mathrm{uw} / \mathrm{dm}=0.45-0.55)\end{array}$ & $\begin{array}{l}\text { strongly depressed; strongly embracing } \\
(\mathrm{w} w / w h=2.00-2.50 ; \mid \mathrm{ZR}=0.35-0.45)\end{array}$ & $\begin{array}{l}\text { very low } \\
(\text { WER }=1.35-1.45)\end{array}$ \\
\hline $8 \mathrm{~mm}$ & $\begin{array}{l}\text { thinly pachyconic; subevolute } \\
(\text { ww/dm }=0.60-0.70 ; u w / d m=0.35-0.40)\end{array}$ & $\begin{array}{l}\text { moderately depressed; strongly embracing } \\
(\mathrm{w} w / w h=1.75-1.90 ; \text { IZR }=0.40-0.45)\end{array}$ & $\begin{array}{l}\text { low } \\
(\text { WER }=1.50-1.65)\end{array}$ \\
\hline $20 \mathrm{~mm}$ & $\begin{array}{l}\text { thickly pachyconic; subevolute } \\
(\mathrm{w} w / \mathrm{dm}=0.72-0.75 ; \mathrm{uw} / \mathrm{dm}=0.30-0.40)\end{array}$ & $\begin{array}{l}\text { moderately to strongly depressed; strongly embracing } \\
(\mathrm{w} w / \mathrm{wh}=1.80-2.20 ; \mathrm{IZR}=0.35-0.45)\end{array}$ & $\begin{array}{l}\text { low } \\
(\text { WER }=1.55-1.70)\end{array}$ \\
\hline
\end{tabular}

Table 59. Conch dimensions (in $\mathrm{mm}$ ) and proportions for reference specimens of Semibollandites pauculus $\mathrm{n}$. sp.

\begin{tabular}{lrrrrrrrrrr}
\hline & $\mathrm{dm}$ & ww & wh & uw & ah & ww/dm & ww/wh & uw/dm & WER & IZR \\
\hline holotype MB.C.18700.1 & 17.0 & 12.2 & 6.5 & 6.5 & 3.9 & 0.72 & 1.88 & 0.38 & 1.68 & 0.40 \\
paratype MB.C.18700.6 & 12.3 & 8.8 & 3.8 & 5.0 & 2.4 & 0.72 & 2.32 & 0.41 & 1.55 & 0.36 \\
paratype MB.C.18700.2 & 11.5 & 8.3 & 3.7 & 4.9 & 2.3 & 0.72 & 2.24 & 0.43 & 1.56 & 0.38 \\
\hline
\end{tabular}

Table 60. Suture line proportions (Figs 51C, D) for Semibollandites pauculus n. sp.

\begin{tabular}{llllllll}
\hline specimen & at dm & EL w/d & EL/VLS & EL/AL & MS h & VLS w/h & remarks \\
\hline paratype MB.C.18700.4 & $13.5 \mathrm{~mm}$ & 0.55 & 0.63 & 0.95 & 0.15 & 0.87 & E lobe moderately strong diverging \\
paratype MB.C.18700.5 & $12.0 \mathrm{~mm}$ & 0.65 & 0.80 & 1.00 & 0.23 & 0.80 & \\
\hline
\end{tabular}

Discussion. Semibollandites pauculus differs from the co-occurring species S. kamil in the presence of a growth interval (between 3 and $8 \mathrm{~mm} \mathrm{dm}$ ) with a rather strong reduction of the uw/ $\mathrm{dm}$ ratio and a subsequent re-opening of the umbilicus. Much closer in appearance is $S$. qawiy, but in this species, the umbilicus is much narrower in the juvenile stage (uw/dm $=0.40-0.45$ at $6 \mathrm{~mm} \mathrm{dm}$ in $S$. pauculus but $0.32-0.37$ in $S$. qawiy).

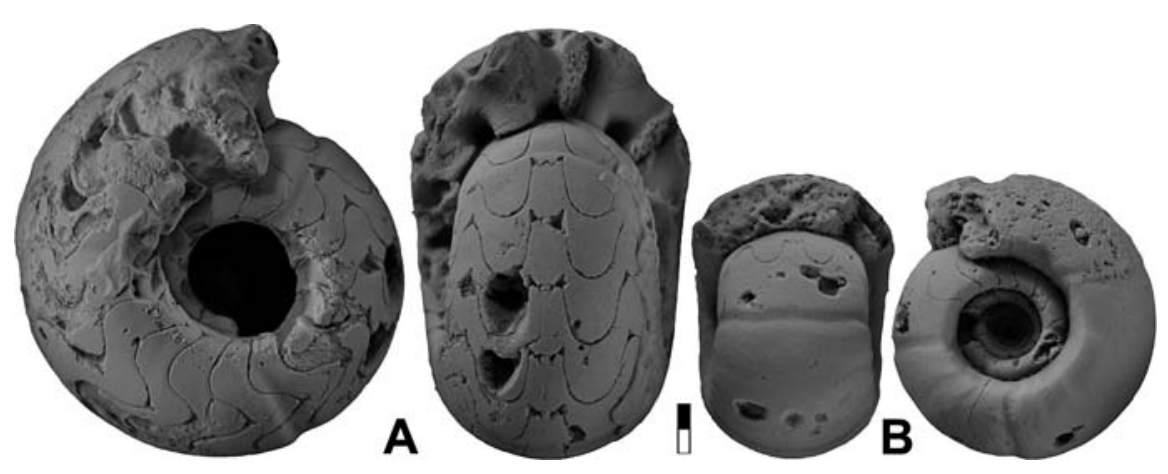

Figure 50. Semibollandites pauculus n. sp. from locality TIM-C8; all $\times 2.5$. A. Holotype MB.C. 18700.1 . B. Paratype MB.C.18700.2. 

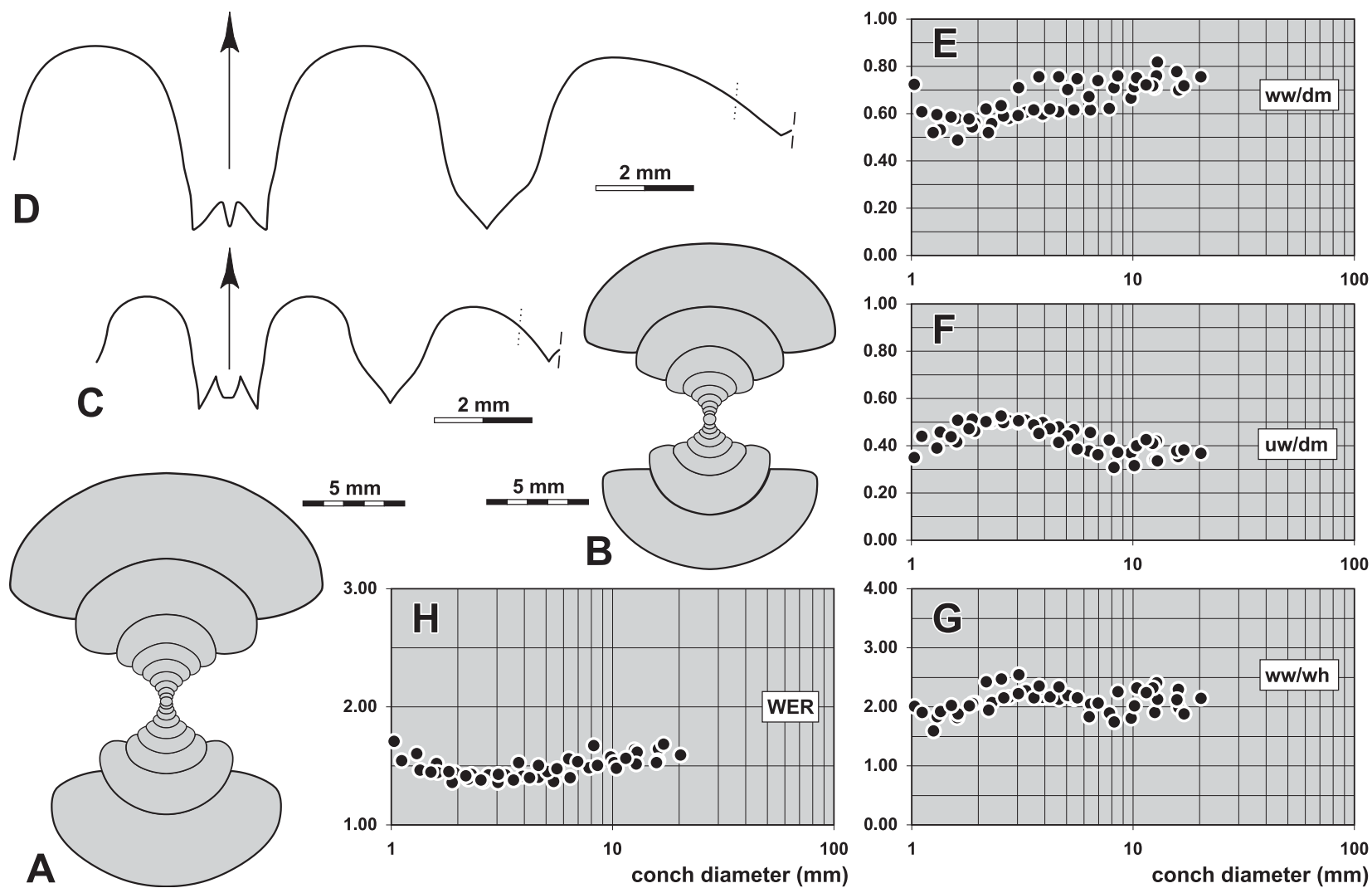

Figure 51. Semibollandites pauculus n. sp. from locality TIM-C8. A. Cross section of paratype MB.C.18700.3; $\times 2.5$. B. Cross section of paratype MB.C. $18700.4 ; \times 2.5$. C. Suture line of paratype MB.C. 18700.5 , at $12.0 \mathrm{~mm} \mathrm{dm}, 7.3 \mathrm{~mm} w w ; \times 6.0$. D. Suture line of paratype MB.C.18700.4, at $13.5 \mathrm{~mm} \mathrm{dm}, 11.4 \mathrm{~mm}$ ww, $6.2 \mathrm{~mm}$ wh; $\times 6.0$. E-H. Ontogenetic development of the conch width index (ww/dm), umbilical width index (uw/dm), whorl width index (ww/wh), and whorl expansion rate (WER) of all available specimens.

\section{Semibollandites qawiy n. sp.}

Figures 52, 53

Derivation of name. From the Arabic al-qawiy = the strong, because of the conch shape.

Holotype. Specimen MB.C.18701.1, illustrated in Figure Fig. 52A.

Type locality and horizon. Sebkha de Timimoun, locality TIM-C8 (13.3 km west of Timimoun, Algeria); Upper Bollandoceras-Bollandites Assemblage.

Material. 55 specimens, conch diameter between 7 and $22 \mathrm{~mm}$.

Diagnosis. Semibollandites with moderate ontogenetic changes of conch geometry: conch evolute in the early juvenile stage (at $2 \mathrm{~mm} \mathrm{dm})$ and then becoming subevolute at $20-30 \mathrm{~mm} \mathrm{dm}$; conch thickly discoidal in early juveniles and becoming in later stages pachyconic; aperture very low to low throughout ontogeny; umbilical margin rounded in juveniles and angular in later stages. Steinkern with shallow, backwardly directed constrictions. Suture line with narrow, strongly diverging external lobe with incurved flanks and very low median saddle; ventrolateral saddle narrowly rounded; adventive lobe V-shaped, symmetric.

Discussion. Semibollandites qawiy resembles the co-occurring species S. pauculus, but differs in the narrower umbilicus at comparable growth stages (for a comparison, see under that species).

Table 61. Conch ontogeny (Figs 53A-D, H-K) of Semibollandites qawiy n. sp.

\begin{tabular}{|c|c|c|c|}
\hline $\mathrm{dm}$ & conch shape & whorl cross section shape & aperture \\
\hline $2 \mathrm{~mm}$ & $\begin{array}{l}\text { thinly to thickly pachyconic; evolute } \\
(\mathrm{ww} / \mathrm{dm}=0.60-0.75 ; \mathrm{uw} / \mathrm{dm}=0.45-0.55)\end{array}$ & $\begin{array}{l}\text { strongly depressed; strongly embracing } \\
(\mathrm{ww} / \mathrm{wh}=2.00-2.50 ; \mathrm{IZR}=0.30-0.35)\end{array}$ & $\begin{array}{l}\text { very low to low } \\
(\text { WER }=1.40-1.55)\end{array}$ \\
\hline $8 \mathrm{~mm}$ & $\begin{array}{l}\text { thinly to thickly pachyconic; subevolute } \\
(\mathrm{ww} / \mathrm{dm}=0.70-0.80 ; \mathrm{uw} / \mathrm{dm}=0.30-0.40)\end{array}$ & $\begin{array}{l}\text { moderately to strongly depressed; strongly embracing } \\
(\mathrm{ww} / \mathrm{wh}=1.90-2.20 ; \mathrm{IZR}=0.35-0.45)\end{array}$ & $\begin{array}{l}\text { low } \\
(\text { WER }=1.50-1.70)\end{array}$ \\
\hline $20 \mathrm{~mm}$ & $\begin{array}{l}\text { thinly to thickly pachyconic; subevolute } \\
(\mathrm{ww} / \mathrm{dm}=0.65-0.75 ; \mathrm{uw} / \mathrm{dm}=0.30-0.40)\end{array}$ & $\begin{array}{l}\text { moderately depressed; strongly embracing } \\
(\mathrm{ww} / \mathrm{wh}=1.60-2.00 ; \mathrm{IZR}=0.40-0.45)\end{array}$ & $\begin{array}{l}\text { low } \\
(\text { WER }=1.50-1.70)\end{array}$ \\
\hline
\end{tabular}



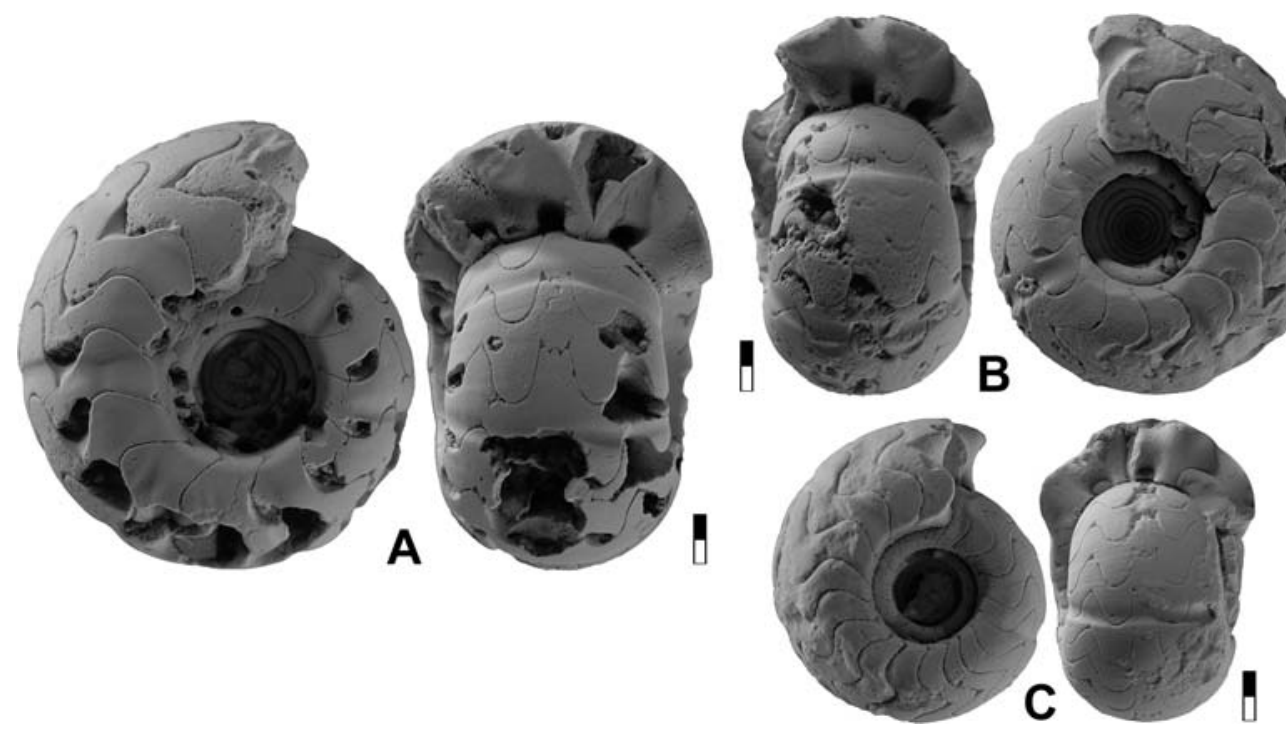

Figure 52. Semibollandites qawiy n. sp. from locality TIM-C8; all $\times 2.5$. A. Holotype MB.C.18701.1. B. Paratype MB.C.18701.2. C. Paratype MB.C.18701.3.
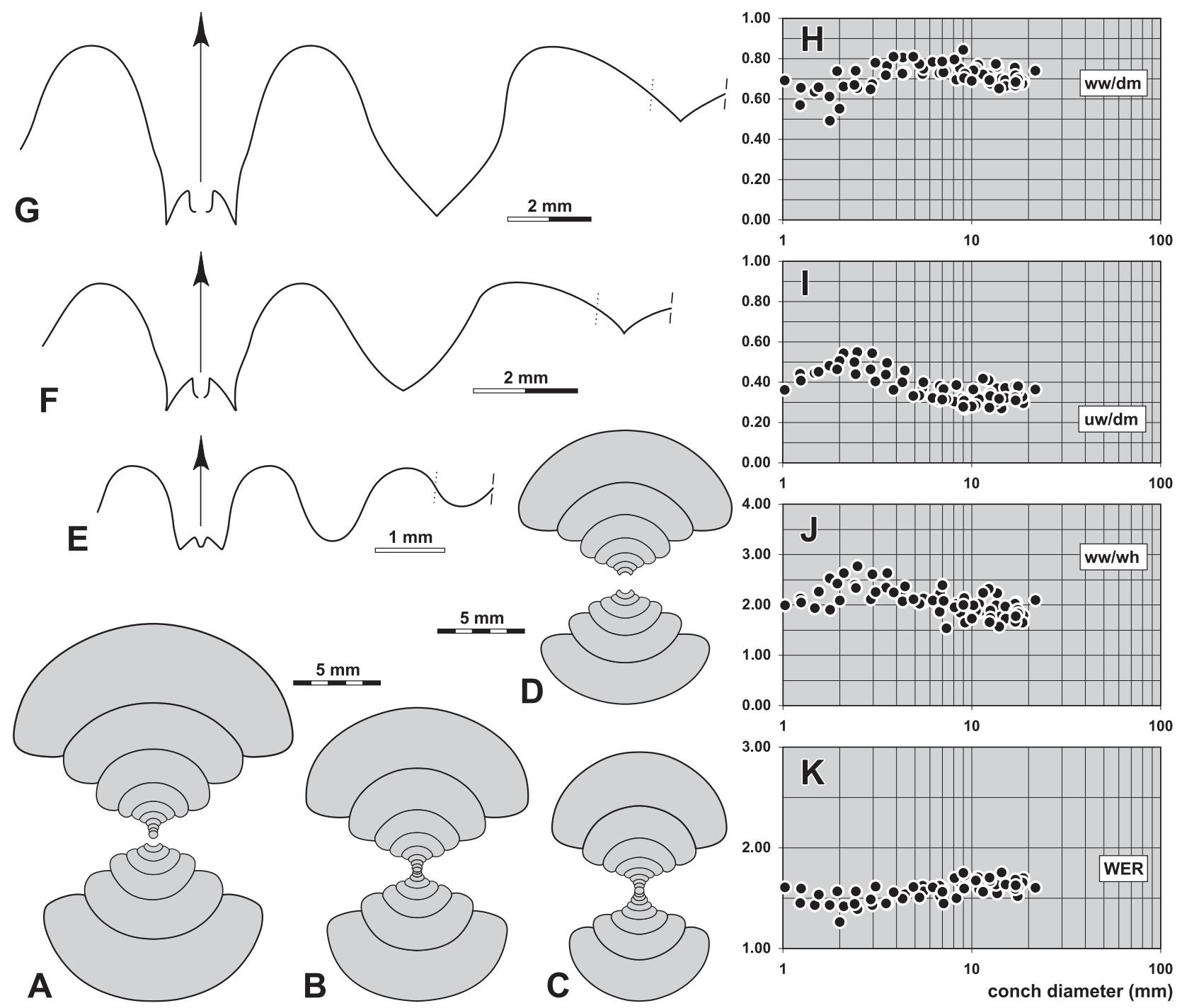

Figure 53. Semibollandites qawiy n. sp. from locality TIM-C8. A. Cross section of paratype MB.C.18701.4; $\times 2.5$. B. Cross section of paratype MB.C.18701.5; $\times 2.5$. C. Cross section of paratype MB.C.18701.6; $\times 2.5$. D. Cross section of paratype MB.C.18701.7; $\times 2.5$. E. Suture line of paratype MB.C.18701.8, at $5.2 \mathrm{~mm} \mathrm{dm}, 3.8 \mathrm{~mm} w w ; \times 10.0$. F. Suture line of paratype MB.C.18701.5, at $8.8 \mathrm{~mm}$ ww, $4.8 \mathrm{~mm}$ wh; $\times 7.5$. G. Suture line of paratype MB.C.18701.9, at $19.0 \mathrm{~mm} \mathrm{dm}, 13.0 \mathrm{~mm} \mathrm{ww} \times 6.0$. H-K. Ontogenetic development of the conch width index (ww/dm), umbilical width index (uw/dm), whorl width index (ww/wh), and whorl expansion rate (WER) of all available specimens. 
Table 62. Conch dimensions (in $\mathrm{mm}$ ) and proportions for reference specimens of Semibollandites qawiy n. sp.

\begin{tabular}{|c|c|c|c|c|c|c|c|c|c|c|}
\hline & $\mathrm{dm}$ & wW & wh & uw & ah & $w w / d m$ & ww/wh & $\mathrm{uw} / \mathrm{dm}$ & WER & IZR \\
\hline holotype MB.C.18701.1 & 18.6 & 12.6 & 7.6 & 6.1 & 4.2 & 0.68 & 1.65 & 0.33 & 1.66 & 0.45 \\
\hline paratype MB.C.18701.11 & 17.6 & 12.3 & 6.7 & 6.7 & 3.7 & 0.70 & 1.84 & 0.38 & 1.60 & 0.45 \\
\hline paratype MB.C.18701.10 & 17.0 & 11.3 & 6.8 & 5.5 & 3.5 & 0.67 & 1.66 & 0.33 & 1.59 & 0.48 \\
\hline paratype MB.C.18701.2 & 15.1 & 10.0 & 5.8 & 4.9 & 3.3 & 0.66 & 1.73 & 0.32 & 1.63 & 0.43 \\
\hline paratype MB.C.18701.3 & 12.5 & 8.7 & 5.0 & 4.2 & 2.8 & 0.70 & 1.75 & 0.33 & 1.67 & 0.43 \\
\hline paratype MB.C.18701.12 & 12.4 & 8.6 & 5.2 & 3.4 & 2.9 & 0.69 & 1.65 & 0.27 & 1.70 & 0.44 \\
\hline paratype MB.C.18701.13 & 9.2 & 6.7 & 4.1 & 2.5 & 2.2 & 0.73 & 1.64 & 0.27 & 1.73 & 0.46 \\
\hline
\end{tabular}

Table 63. Suture line proportions (Figs 53E-G) for Semibollandites qawiy n. sp.

\begin{tabular}{llllllll}
\hline specimen & at dm & EL w/d & EL/VLS & EL/AL & MS h & VLS w/h & remarks \\
\hline paratype MB.C.18701.9 & $19.0 \mathrm{~mm}$ & 0.57 & 0.85 & 0.82 & 0.19 & 0.68 & \\
paratype MB.C.18701.7 & $15.5 \mathrm{~mm}$ & 0.67 & 0.75 & 0.86 & 0.15 & 0.88 & E lobe strongly diverging \\
paratype MB.C.18701.5 & c. $13.0 \mathrm{~mm}$ & 0.75 & 0.86 & 0.92 & 0.25 & 0.87 & A lobe very wide \\
paratype MB.C.18701.8 & $5.2 \mathrm{~mm}$ & 0.73 & 0.86 & 0.95 & 0.14 & 0.85 & A lobe rounded \\
\hline
\end{tabular}

\section{Timimounia n. gen.}

Derivation of name. After Timimoun, where the material was found.

Type species. Timimounia timimounensis n. sp.

Genus definition. Genus of the subfamily Bollanditinae with minor ontogenetic changes of conch morphology (Fig. 54); adult conch pachyconic with slowly expanding whorls (WER less than 1.60 in stages larger than $10 \mathrm{~mm}$ conch diameter); conch evolute throughout ontogeny. Suture line in the adult stage with very narrow, subparallel-sided, weakly divergent external lobe with slightly incurved flanks; median saddle usually very low; ventrolateral saddle rounded; adventive lobe V-shaped.

Included species.

lunula: Timimounia lunula n. sp.: Gourara, Algeria.

timimounensis: Timimounia timimounensis n. sp.: Gourara, Algeria.

Discussion. Timimounia is the only genus of the subfamily with an evolute conch throughout ontogeny. It differs from Semibollandites also in the shape of the external lobe, which has subparallel flanks in Timimounia but is Vshaped in Semibollandites.
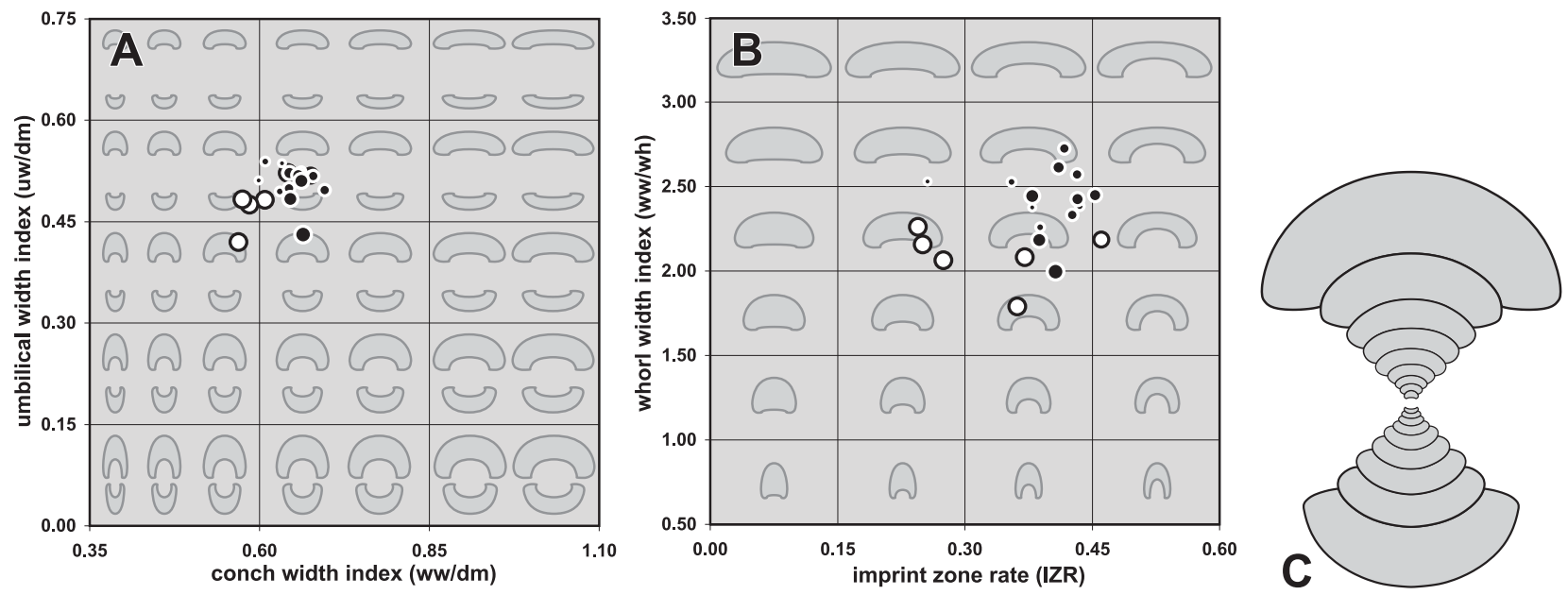

Figure 54. Ontogenetic trajectories of Timimounia, exemplified for T. timimounensis n. sp. from locality TIM-B3. A. Ontogenetic development of the conch width index (ww/dm) and umbilical width index (uw/dm). B. Ontogenetic development of the imprint zone rate (IZR) and whorl width index (ww/wh). C. Cross section of paratype MB.C.18702.4; $\times 2.5$. [Black dots represent ontogenetic stages of cross section MB.C.18702.4, white dots represent the reference specimens (Tab. 65).] 


\section{Timimounia timimounensis $\mathbf{n}$. sp.}

\section{Figures 55, 56}

Derivation of name. After Timimoun, where the material was found.

Holotype. Specimen MB.C.18702.1, illustrated in Figure 55A.

Type locality and horizon. Sebkha de Timimoun, locality TIM-C8 (13.3 km west of Timimoun, Algeria); Upper Bollandoceras-Bollandites Assemblage.

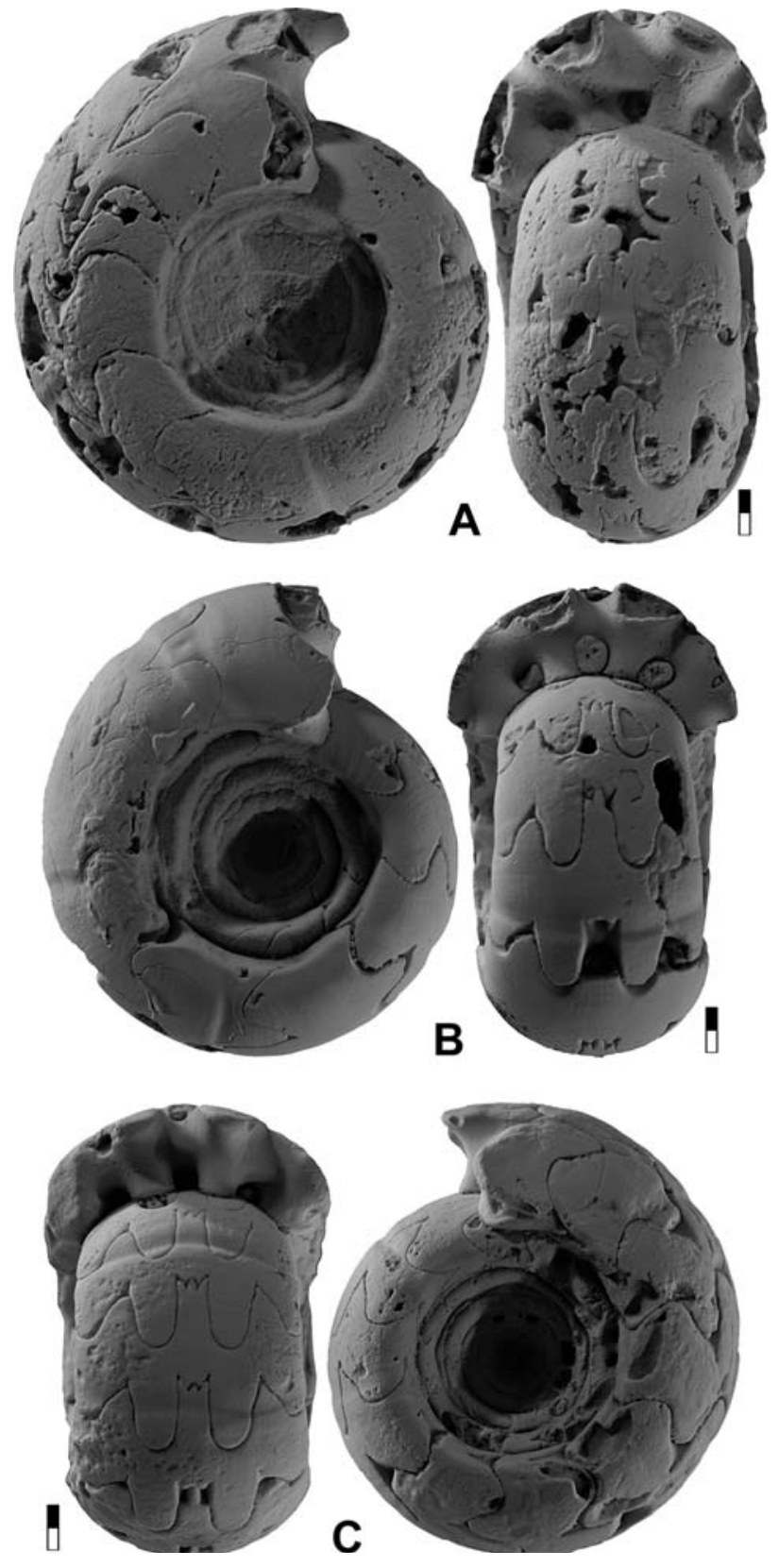

Material. 70 specimens, conch diameter between 8 and $25 \mathrm{~mm}$.

Diagnosis. Timimounia with minor ontogenetic changes of conch geometry: conch evolute in the juvenile and preadult stage $(1.5-14 \mathrm{~mm}$ $\mathrm{dm}$ ) and evolute at $20 \mathrm{~mm} \mathrm{dm}$; conch thickly discoidal or thinly pachyconic throughout ontogeny, larger stages stouter than juveniles; aperture very low in juveniles $(2-15 \mathrm{~mm} \mathrm{dm})$ and then slowly increasing but still relatively low at $20 \mathrm{~mm}$ dm; umbilical margin subangular in juveniles and angular in later stages. Steinkern with shallow, almost straight constrictions and traces of concavo-convex growth lines. Suture line with very narrow, almost parallel-sided external lobe with slightly incurved flanks and very low median saddle; ventrolateral saddle rounded; small adventive lobe V-shaped, almost symmetric.

Table 64. Conch ontogeny (Figs 56A-D, G-J) of Timimounia timimounensis n. sp.

\begin{tabular}{|c|c|c|c|}
\hline $\mathrm{dm}$ & conch shape & whorl cross section shape & aperture \\
\hline $2 \mathrm{~mm}$ & $\begin{array}{l}\text { thickly discoidal to thinly pachyconic; evolute } \\
(\mathrm{ww} / \mathrm{dm}=0.48-0.65 ; \mathrm{uw} / \mathrm{dm}=0.48-0.60)\end{array}$ & $\begin{array}{l}\text { strongly depressed; strongly embracing } \\
(\mathrm{ww} / \mathrm{wh}=2.00-2.50 ; \mathrm{IZR}=0.30-0.40)\end{array}$ & $\begin{array}{l}\text { very low } \\
(\text { WER }=1.40-1.45)\end{array}$ \\
\hline $8 \mathrm{~mm}$ & $\begin{array}{l}\text { thinly pachyconic; evolute } \\
(\mathrm{ww} / \mathrm{dm}=0.60-0.70 ; \mathrm{uw} / \mathrm{dm}=0.50-0.58\end{array}$ & $\begin{array}{l}\text { very strongly depressed; strongly to very strongly } \\
\text { embracing ( } w w / w h=2.50-2.90 ; \mathrm{IZR}=0.35-0.50)\end{array}$ & $\begin{array}{l}\text { very low } \\
(\text { WER }=1.35-1.45)\end{array}$ \\
\hline $20 \mathrm{~mm}$ & $\begin{array}{l}\text { thickly discoidal to thinly pachyconic; evolute } \\
(\mathrm{ww} / \mathrm{dm}=0.58-0.68 ; \mathrm{uw} / \mathrm{dm}=0.45-0.50)\end{array}$ & $\begin{array}{l}\text { moderately to strongly depressed; strongly embracing } \\
(\mathrm{ww} / \mathrm{wh}=1.80-2.20 ; \mathrm{IZR}=0.30-0.45)\end{array}$ & $\begin{array}{l}\text { low } \\
(\text { WER }=1.50-1.60)\end{array}$ \\
\hline
\end{tabular}

Figure 55. Timimounia timimounensis $\mathrm{n}$. sp. from locality TIMC8; all $\times 2.5$. A. Holotype MB.C.18702.1. B. Paratype MB.C.18702.2. C. Paratype MB.C.18702.3. 
Table 65. Conch dimensions (in $\mathrm{mm}$ ) and proportions for reference specimens of Timimounia timimounensis $\mathrm{n}$. sp.

\begin{tabular}{lcccccccccc}
\hline & dm & ww & wh & uw & ah & ww/dm & ww/wh & uw/dm & WER & IZR \\
\hline holotype MB.C.18702.1 & 24.1 & 13.7 & 7.6 & 10.1 & 4.9 & 0.57 & 1.80 & 0.42 & 1.57 & 0.36 \\
paratype MB.C.18702.2 & 20.9 & 12.7 & 6.1 & 10.1 & 3.8 & 0.61 & 2.09 & 0.48 & 1.50 & 0.37 \\
paratype MB.C.18702.8 & 20.6 & 12.1 & 5.6 & 9.8 & 4.2 & 0.59 & 2.16 & 0.48 & 1.57 & 0.25 \\
paratype MB.C.18702.3 & 20.3 & 12.6 & 7.0 & 9.5 & 3.6 & 0.62 & 1.81 & 0.47 & 1.48 & 0.49 \\
paratype MB.C.18702.9 & 18.5 & 10.6 & 5.1 & 8.9 & 3.7 & 0.57 & 2.07 & 0.48 & 1.57 & 0.27 \\
paratype MB.C.18702.10 & 15.9 & 10.2 & 4.5 & 8.3 & 3.4 & 0.64 & 2.27 & 0.52 & 1.62 & 0.24 \\
paratype MB.C.18702.11 & 10.7 & 7.2 & 3.3 & 5.6 & 1.8 & 0.68 & 2.19 & 0.52 & 1.44 & 0.46 \\
\hline
\end{tabular}

Table 66. Suture line proportions (Figs 56E, F) for Timimounia timimounensis n. sp.

\begin{tabular}{llllllll}
\hline specimen & at dm & EL w/d & EL/VLS & EL/AL & MS h & VLS w/h & remarks \\
\hline paratype MB.C.18702.2 & $19.5 \mathrm{~mm}$ & 0.38 & 0.64 & 0.83 & 0.17 & 0.60 & A lobe with curved ventral flank \\
holotype MB.C.18702.5 & $14.0 \mathrm{~mm}$ & 0.41 & 0.57 & 0.89 & 0.14 & 0.72 & A lobe almost symmetric \\
\hline
\end{tabular}
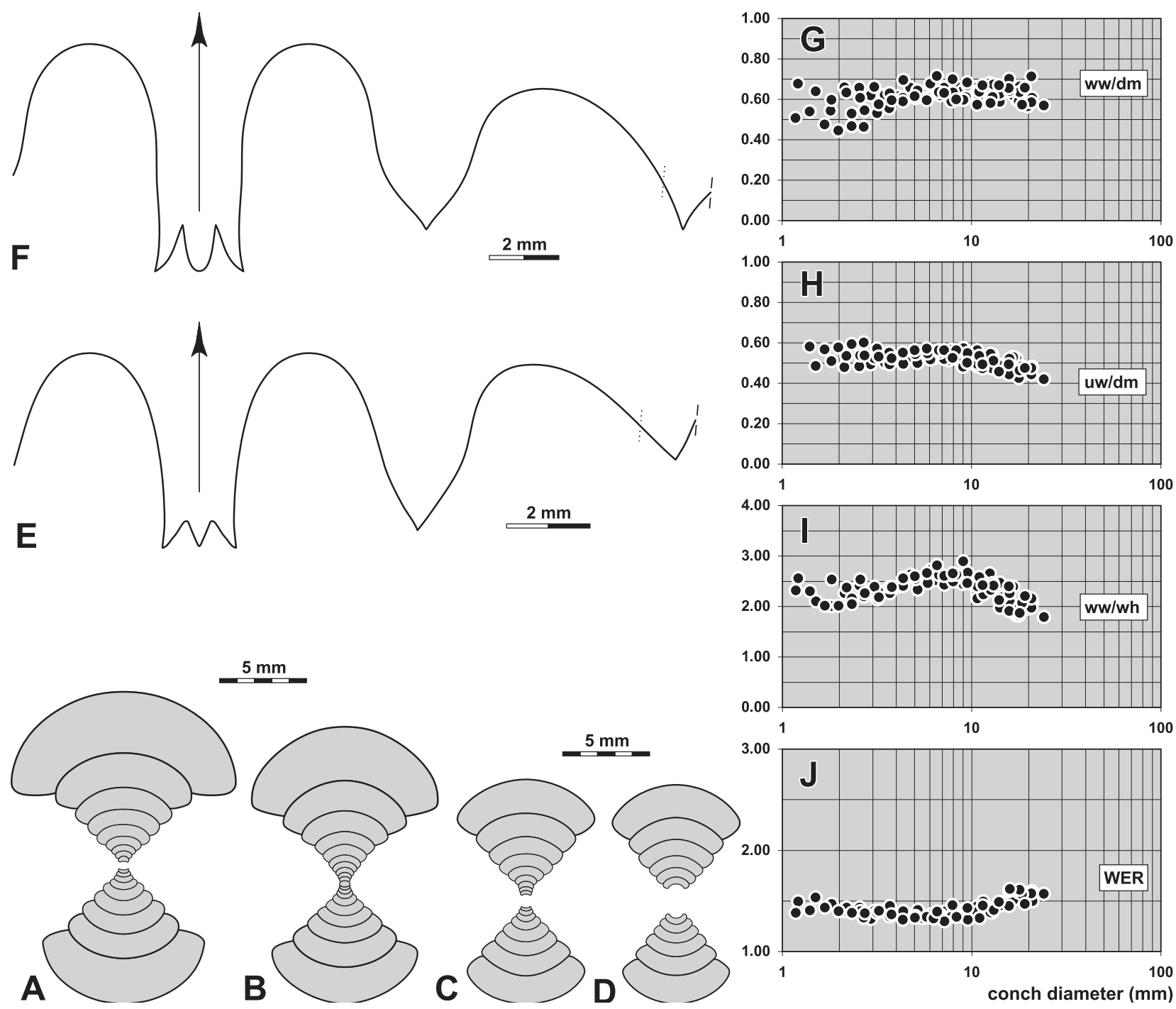

Figure 56. Timimounia timimounensis n. sp. from locality TIM-C8. A. Cross section of paratype MB.C.18702.4; $\times 2.5$. B. Cross section of paratype MB.C.18702.5; $\times 2.5$. C. Cross section of paratype MB.C.18702.6; $\times 2.5$. D. Cross section of paratype MB.C. $18702.7 ; \times 2.5$. E. Suture line of paratype MB.C.18702.5, at $14.0 \mathrm{~mm} \mathrm{dm}, 9.5 \mathrm{~mm}$ ww, $4.2 \mathrm{~mm}$ wh; $\times 6.0$. F. Suture line of paratype MB.C.18702.2, at $19.5 \mathrm{~mm} \mathrm{dm}, 11.5 \mathrm{~mm}$ ww, $6.0 \mathrm{~mm}$ wh; $\times 5.0$. G-J. Ontogenetic development of the conch width index (ww/dm), umbilical width index (uw/dm), whorl width index (ww/wh), and whorl expansion rate (WER) of all available specimens. 
Discussion. Timimounia timimounensis has a position morphologically between Semibollandoceras kamil and T. lunula. It has a wider umbilicus, caused by slower ontogenetic reduction of the uw/dm ratio, than $S$. kamil, but, in the adult stage, it has a narrower umbilicus than T. lunula. The suture line of T. timimounensis has a very narrow external lobe with subparallel flanks, in contrast to $S$. kamil that possesses a wider external lobe with diverging flanks. T. lunula differs in the ventrally very strongly depressed whorl cross section from T. timimounensis.

\section{Timimounia lunula n. sp.}

Figures 57, 58

Derivation of name. From Latin lunula $=$ half moon, because of the whorl cross section shape.

Holotype. Specimen MB.C.18703.1, illustrated in Figure 57A.

Type locality and horizon. Sebkha de Timimoun, locality TIM-C8 (13.3 km west of Timimoun, Algeria); Upper Bollandoceras-Bollandites Assemblage.

Material. 83 specimens, conch diameter between 8 and $18 \mathrm{~mm}$.

Diagnosis. Timimounia with minor ontogenetic changes of conch geometry: conch pachyconic and evolute throughout ontogeny; umbilical margin angular in all growth stages larger than $1.5 \mathrm{~mm}$. Steinkern with shallow, almost straight constrictions and traces of almost linear growth lines. Suture line with very narrow, weakly diverging external lobe with incurved flanks and very low median saddle; ventrolateral saddle broadly rounded; adventive lobe V-shaped, symmetric.

Table 67. Conch ontogeny (Figs 58A-C, G-J) of Timimounia lunula n. sp.

\begin{tabular}{|c|c|c|c|}
\hline $\mathrm{dm}$ & conch shape & whorl cross section shape & aperture \\
\hline $2 \mathrm{~mm}$ & $\begin{array}{l}\text { thinly to thickly pachyconic; evolute } \\
\text { (ww/dm }=0.65-0.75 ; \mathrm{uw} / \mathrm{dm}=0.50-0.55 \text { ) }\end{array}$ & $\begin{array}{l}\text { very strongly depressed; strongly embracing } \\
(\mathrm{w} w / \mathrm{wh}=2.70-3.00 ; \mathrm{IZR}=0.30-0.40)\end{array}$ & $\begin{array}{l}\text { very low } \\
(\text { WER }=1.40-1.45)\end{array}$ \\
\hline $8 \mathrm{~mm}$ & $\begin{array}{l}\text { thinly to thickly pachyconic; evolute } \\
\text { (ww/dm }=0.65-0.75 ; u w / d m=0.50-0.58 \text { ) }\end{array}$ & $\begin{array}{l}\text { very strongly to extremely depressed; strongly embracing } \\
(w w / w h=2.70-3.30 ; \mathrm{IZR}=0.30-0.40)\end{array}$ & $\begin{array}{l}\text { very low } \\
(\text { WER }=1.35-1.45)\end{array}$ \\
\hline $20 \mathrm{~mm}$ & $\begin{array}{l}\text { thinly to thickly pachyconic; evolute } \\
(\mathrm{ww} / \mathrm{dm}=0.60-0.80 ; \mathrm{uw} / \mathrm{dm}=0.50-0.55)\end{array}$ & $\begin{array}{l}\text { strongly to very strongly depressed; strongly embracing } \\
\text { ( } w w / w h=2.40-2.80 ; \mid I Z R=0.30-0.40)\end{array}$ & $\begin{array}{l}\text { very low to low } \\
\text { (WER }=1.45-1.55)\end{array}$ \\
\hline
\end{tabular}
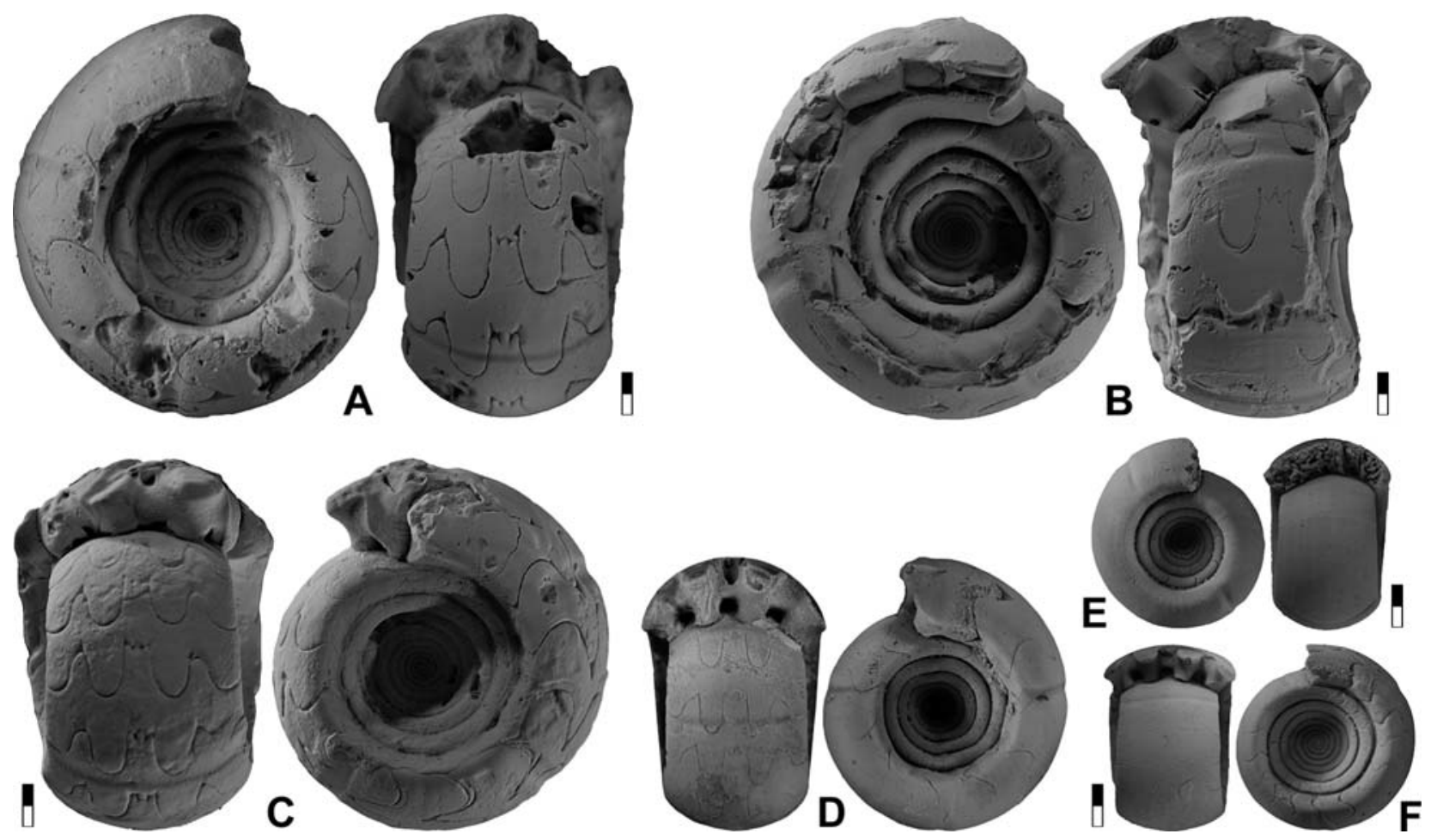

Figure 57. Timimounia lunula n. sp. from locality TIM-C8; all $\times 2.5$. A. Holotype MB.C.18703.1. B. Paratype MB.C.18703.2. C. Paratype MB.C.18703.3. D. Paratype MB.C.18703.4. E. Paratype MB.C.18703.5. F. Paratype MB.C.18703.6. 
Table 68. Conch dimensions (in $\mathrm{mm}$ ) and proportions for reference specimens of Timimounia lunula $\mathrm{n}$. sp.

\begin{tabular}{|c|c|c|c|c|c|c|c|c|c|c|}
\hline & $\mathrm{dm}$ & ww & wh & uw & ah & $w w / d m$ & ww/wh & $\mathrm{uw} / \mathrm{dm}$ & WER & IZR \\
\hline holotype MB.C.18703.1 & 19.0 & 12.1 & 4.7 & 9.6 & 3.5 & 0.64 & 2.57 & 0.51 & 1.50 & 0.26 \\
\hline paratype MB.C.18703.3 & 17.8 & 12.4 & 5.1 & 9.0 & 3.3 & 0.70 & 2.43 & 0.51 & 1.50 & 0.36 \\
\hline paratype MB.C.18703.11 & 17.4 & 12.0 & 4.2 & 8.1 & 3.2 & 0.69 & 2.86 & 0.47 & 1.50 & 0.24 \\
\hline paratype MB.C.18703.4 & 12.6 & 8.4 & 3.0 & 6.2 & 2.3 & 0.67 & 2.80 & 0.49 & 1.50 & 0.23 \\
\hline paratype MB.C.18703.6 & 8.8 & 6.0 & 1.4 & 5.2 & 1.2 & 0.68 & 4.29 & 0.59 & 1.34 & 0.14 \\
\hline paratype MB.C.18703.5 & 8.8 & 5.7 & 1.9 & 4.4 & 1.6 & 0.65 & 2.97 & 0.50 & 1.50 & 0.17 \\
\hline
\end{tabular}

Table 69. Suture line proportions (Figs 58D-F) for Timimounia lunula n. sp.

\begin{tabular}{lccccccc}
\hline specimen & at dm & EL w/d & EL/VLS & EL/AL & MS h & VLS w/h remarks \\
\hline paratype MB.C.18703.2 & $17.0 \mathrm{~mm}$ & 0.43 & 0.62 & 0.79 & 0.17 & 0.70 & A lobe almost symmetric \\
paratype MB.C.18703.7 & $9.9 \mathrm{~mm}$ & 0.69 & 0.91 & 1.27 & 0.17 & 0.76 & E lobe narrow \\
paratype MB.C.18703.10 & $9.0 \mathrm{~mm}$ & 0.72 & 1.11 & 1.24 & 0.21 & 0.65 & E lobe narrow \\
\hline
\end{tabular}
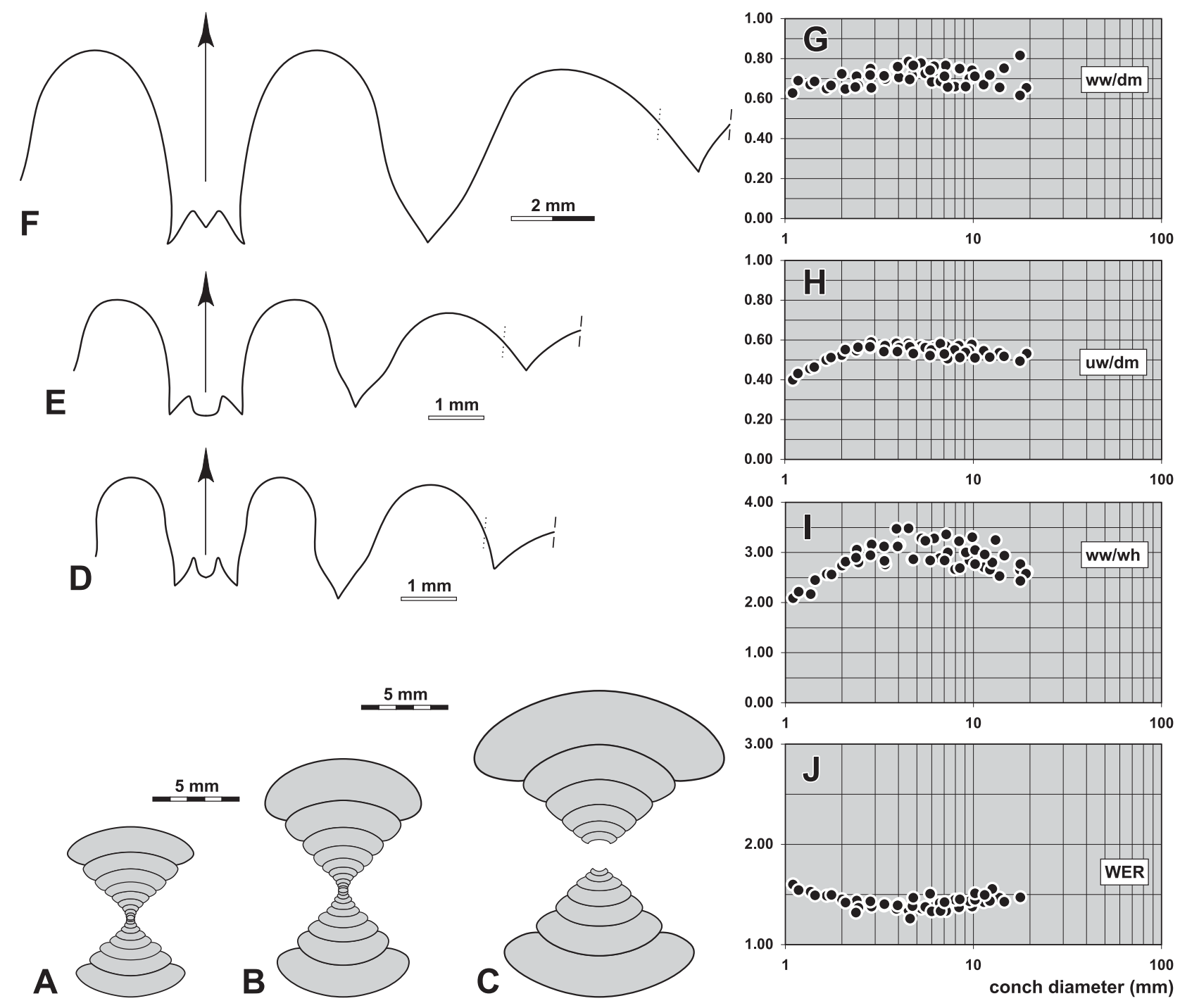

Figure 58. Timimounia lunula n. sp. from locality TIM-C8. A. Cross section of paratype MB.C.18703.7; $\times 2.5$. B. Cross section of paratype MB.C.18703.8; $\times 2.5$. C. Cross section of paratype MB.C.18703.9; $\times 2.5$. D. Suture line of paratype MB.C.18703.10, at $9.0 \mathrm{~mm} \mathrm{dm}, 7.3 \mathrm{~mm} w w ; \times 8.0$. E. Suture line of paratype MB.C.18703.7, at $9.9 \mathrm{~mm} \mathrm{dm}, 7.2 \mathrm{~mm}$ ww, $2.1 \mathrm{~mm}$ wh; $\times 8.0$. F. Suture line of paratype MB.C.18703.2, at $17.0 \mathrm{~mm} \mathrm{dm}, 10.5 \mathrm{~mm} \mathrm{ww}, 4.2 \mathrm{~mm}$ wh; $\times 6.0$. G-J. Ontogenetic development of the conch width index (ww/dm), umbilical width index (uw/dm), whorl width index (ww/wh), and whorl expansion rate (WER) of all available specimens. 
Discussion. Timimounia lunula is the widest umbilicate of all the species from the ammonoid assemblage at TIMC8. It shows, between 2 and $20 \mathrm{~mm}$ conch diameter, an almost isometric growth, in which the cardinal conch parameters are almost stable. All the other species, including those of the genera Semibollandites and Timimounia, show at least an adult stage modification, e.g. in a reduction of the uw/dm ratio. The whorl cross section is very low with depressed venter and differs also from the other species.

\section{Superfamily Dimorphocerataceae Hyatt, 1884}

Included families.

Dimorphoceratidae Hyatt, 1884.

Berkhoceratidae Librovitch, 1957.

Daaitidae n. fam.

Family Daaitidae n. fam.

Subfamily definition. Dimorphocerataceae with a thinly discoidal conch. Suture line with moderately wide V-shaped external lobe, secondary prongs of the external lobe asymmetrically V-shaped with stronger curved ventral side; flanks of the external lobe sinuous, ventrolateral saddle narrowly rounded; adventive lobe less deep than the external lobe.

Included genera.

Winchelloceras Ruzhencev, 1965

Daaites n. gen.

Discussion. The new family is characterised by the unsubdivided prongs of the external lobe, which show only an indication of an incipient subdivision.

\section{Daaites n. gen.}

Type species. Daaites daaensis n. sp.

Derivation of name. After Sidi ed Daâ near Timimoun.

Diagnosis. Genus of the family Daaitidae with discoidal conch and closed umbilicus (Fig. 59). Shell almost smooth, no steinkern constrictions. Suture line with moderately wide, strongly diverging external lobe with strongly sinuous flanks; prongs of the external lobe asymmetric, indicating incipient subdivision; adventive lobe asymmetric with convex flanks.

Included species.

daaensis: Daaites daaensis n. sp.: Gourara, Algeria.

Discussion. The new genus differs from Winchelloceras in the absence of steinkern constrictions, in the stronger converging flanks, and in the higher aperture. However both genera do possess a very similar suture line.

Daaites differs from genera such as Eogonioloboceras Librovitch, 1957 and Arcanoceras Ruzhencev, 1965 in the much more asymmetric prongs of the external lobe, which in the two aforementioned genera are almost Vshaped. The new genus differs also in its closed umbilicus from these two genera. In general conch shape, Daaites shows close resemblance to the genus Dimorphoceras, and the shape of the external lobe may suggest close relationships.
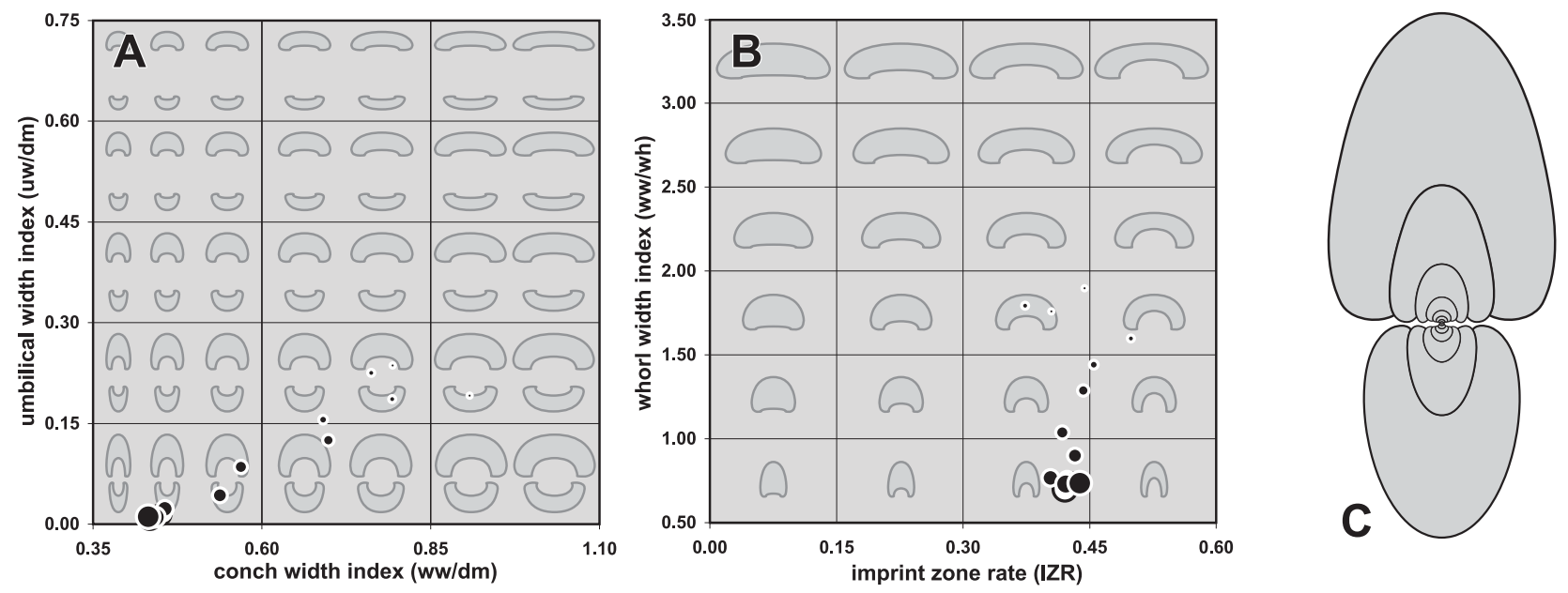

Figure 59. Ontogenetic trajectories of Daaites, exemplified for Daaites daaensis n. sp. from locality TIM-B3. A. Ontogenetic development of the conch width index (ww/dm) and umbilical width index (uw/dm). B. Ontogenetic development of the imprint zone rate (IZR) and whorl width index (ww/wh). C. Cross section of paratype MB.C.18690.6; $\times 1.0$. [Black dots represent ontogenetic stages of cross section MB.C.18690.6, white dots represent the reference specimens (Tab. 71).] 


\section{Daaites daaensis n. sp.}

Figures 60, 61

Derivation of name. After Sidi ed Daâ near Timimoun.

Holotype. Specimen MB.C.18690.1, illustrated in Figure 60B.

Type locality and horizon. Sebkha de Timimoun, locality TIM-B3 (10 km west-southwest of Timimoun, Algeria); upper part of the Lower Bollandoceras-Bollandites Assemblage.

Material. Eleven specimens, conch diameter between 26 and $58 \mathrm{~mm}$.

Diagnosis. Daaites with thickly pachyconic and subinvolute conch in early juveniles, thereafter continuous development to a thinly discoidal and involute conch at $20 \mathrm{~mm} \mathrm{dm}$, adult conch (20-60 $\mathrm{mm} \mathrm{dm}$ ) with almost no changes in conch geometry; aperture moderate in juveniles and rapidly becoming very high at $10-20 \mathrm{~mm} \mathrm{dm}$. Steinkern smooth. Suture line with moderately wide, strongly diverging external lobe with slightly sinuous flanks and low median saddle; ventrolateral saddle narrowly rounded; adventive lobe asymmetrically V-shaped and slightly pouched.

Table 70. Conch ontogeny (Figs 61A-C, E-G) of Daaites daaensis n. sp.

\begin{tabular}{|c|c|c|c|}
\hline $\mathrm{dm}$ & conch shape & whorl cross section shape & aperture \\
\hline $3 \mathrm{~mm}$ & $\begin{array}{l}\text { thickly pachyconic; involute to subinvolute } \\
(\mathrm{ww} / \mathrm{dm}=0.70-0.80 ; \mathrm{uw} / \mathrm{dm}=0.12-0.18)\end{array}$ & $\begin{array}{l}\text { weakly depressed; very strongly embracing } \\
(\mathrm{ww} / \mathrm{wh}=1.40-1.50 ; \mathrm{IZR}=0.45-0.50)\end{array}$ & $\begin{array}{l}\text { moderate } \\
(\mathrm{WER}=1.80-1.95)\end{array}$ \\
\hline $8 \mathrm{~mm}$ & $\begin{array}{l}\text { thickly discoidal; involute } \\
(\mathrm{ww} / \mathrm{dm}=0.55-0.60 \mathrm{uw} / \mathrm{dm}=0.08-0.12)\end{array}$ & $\begin{array}{l}\text { weakly depressed; strongly embracing } \\
\text { (ww/wh =1.00-1.10; IZR =0.40-0.45) }\end{array}$ & $\begin{array}{l}\text { high } \\
(\text { WER }=2.10-2.20)\end{array}$ \\
\hline $20 \mathrm{~mm}$ & $\begin{array}{l}\text { thinly discoidal; involute } \\
(\mathrm{ww} / \mathrm{dm}=0.40-0.45 ; \mathrm{uw} / \mathrm{dm}=0.00-0.05)\end{array}$ & $\begin{array}{l}\text { weakly compressed; strongly embracing } \\
\text { (ww/wh }=0.75-0.80 ; \text { IZR }=0.40-0.45 \text { ) }\end{array}$ & $\begin{array}{l}\text { very high } \\
(\mathrm{WER}=2.30-2.40)\end{array}$ \\
\hline $50 \mathrm{~mm}$ & $\begin{array}{l}\text { thinly discoidal; involute } \\
(\mathrm{ww} / \mathrm{dm}=0.40-0.45 ; \mathrm{uw} / \mathrm{dm}=0.00-0.05)\end{array}$ & $\begin{array}{l}\text { weakly compressed; strongly embracing } \\
\text { (ww/wh }=0.75-0.80 ; \text { IZR }=0.40-0.45 \text { ) }\end{array}$ & $\begin{array}{l}\text { very high } \\
(\mathrm{WER}=2.25-2.45)\end{array}$ \\
\hline
\end{tabular}

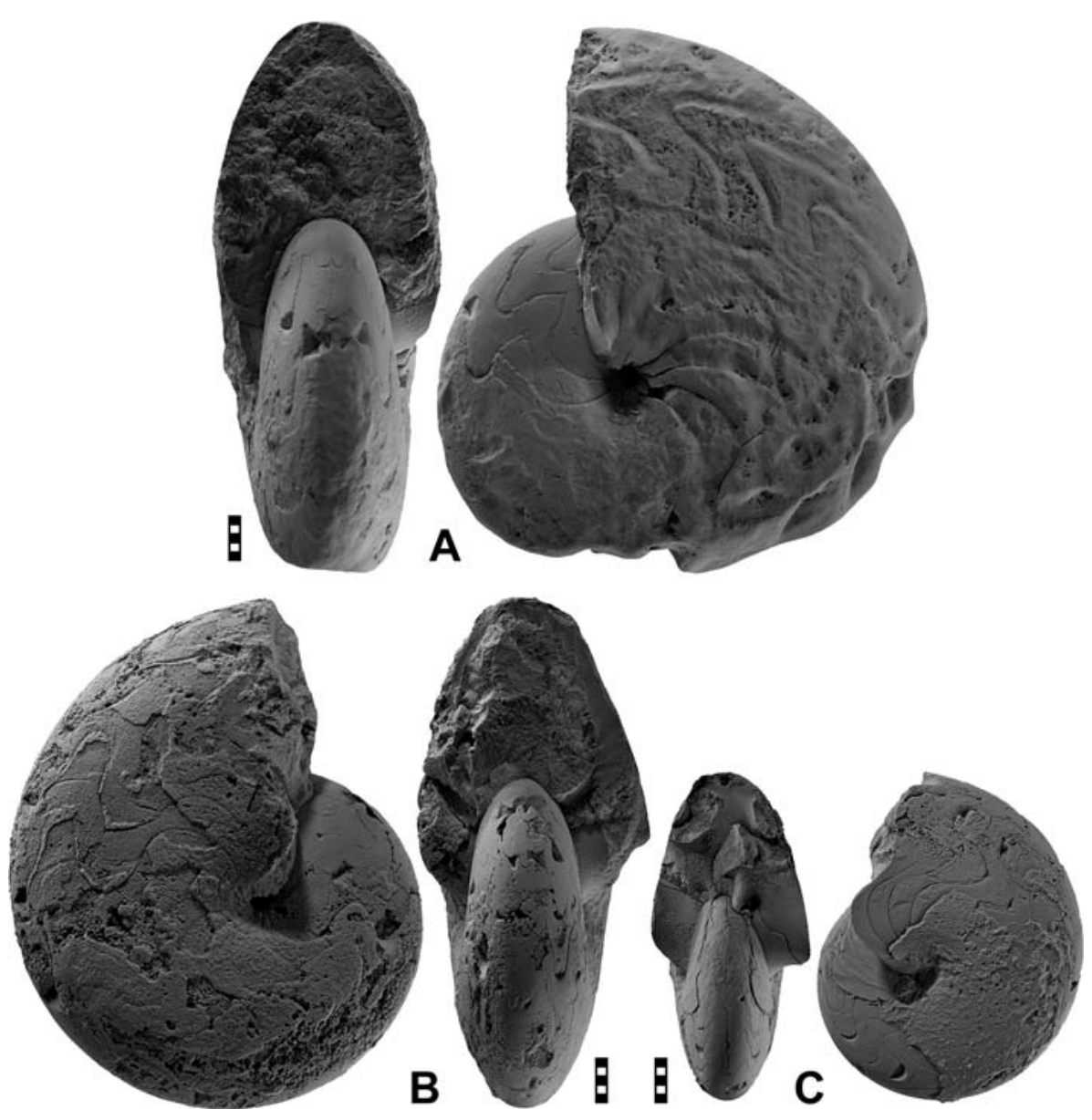

Figure 60. Daaites daaensis n. sp. from locality TIM-B3; all $\times 1.0$. A. Paratype MB.C. 18690.2 . B. Holotype MB.C.18690.1. C. Paratype MB.C.18690.3. 
Table 71. Conch dimensions (in $\mathrm{mm}$ ) and proportions for reference specimens of Daaites daaensis $\mathrm{n}$. $\mathrm{sp}$.

\begin{tabular}{lcccccccccc}
\hline & $\mathrm{dm}$ & ww & wh & uw & ah & ww/dm & ww/wh & uw/dm & WER & IZR \\
\hline holotype MB.C.18690.1 & 56.3 & 24.4 & 34.8 & 0.5 & 20.2 & 0.43 & 0.70 & 0.01 & 2.43 & 0.42 \\
paratype MB.C.18690.3 & 35.6 & 16.0 & 21.6 & 0.5 & 12.3 & 0.45 & 0.74 & 0.01 & 2.33 & 0.43 \\
\hline
\end{tabular}

Table 72. Suture line proportions (Fig. 61D) for Daaites daaensis n. sp.

\begin{tabular}{llllllll}
\hline specimen & at dm & EL w/d & EL/VLS & EL/AL & MS h & VLS w/h & remarks \\
\hline paratype MB.C.18690.2 & c. $33.0 \mathrm{~mm}$ & 1.20 & 2.34 & 2.34 & 0.33 & 0.51 & A lobe with curved ventral flank \\
\hline
\end{tabular}

Discussion. Daaites daaensis cannot be confused easily with any other species from the assemblages found near Timimoun. Its involute lenticular conch and the wide external lobe make it unique among the faunas. A similar suture line can be seen in species of the genus Eogonioloboceras, but here the prongs of the external lobe are rather symmetric. The conch of Eogonioloboceras is narrowly umbilicate and possesses rather strong constrictions, which are absent in Daaites daaensis.

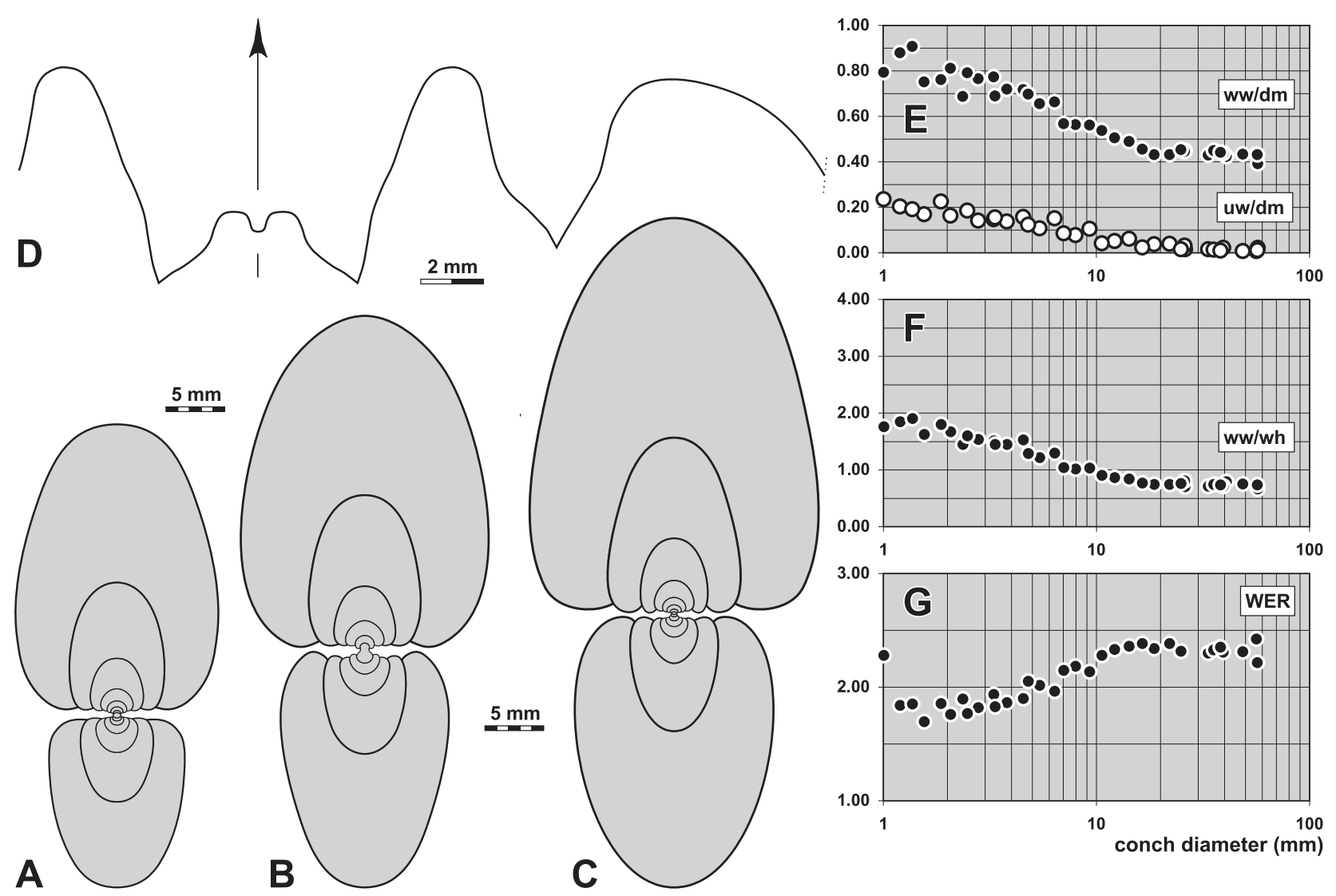

Figure 61. Daaites daaensis n. sp. from locality TIM-B3. A. Cross section of paratype MB.C.18690.4; $\times 1.5$. B. Cross section of paratype MB.C.18690.5; $\times 1.5$. C. Cross section of paratype MB.C.18690.6; $\times 1.5$. D. Suture line of paratype MB.C.18690.2, at cA. $33 \mathrm{~mm} \mathrm{dm}, 13.9 \mathrm{~mm}$ ww, $19.3 \mathrm{~mm}$ wh; $\times 3.5$. E-G. Ontogenetic development of the conch width index (ww/dm), umbilical width index (uw/dm), whorl width index (ww/wh), and whorl expansion rate (WER) of all available specimens.

Family Dimorphoceratidae Hyatt, 1884

\section{Subfamily Dimorphoceratinae Hyatt, 1884}

Included genera.

Dimorphoceras Hyatt, 1884.

Trizonoceras Girty, 1909.

Asturoceras Ruzhencev \& Bogoslovskaya, 1969. 


\section{Dimorphoceras Hyatt, 1884}

Type species. Goniatites gilbertsoni Phillips, 1836 (SD Foord \& Crick 1897).

Genus definition. Genus of the family Dimorphoceratidae with an undivided adventive lobe and an external lobe that is subdivided into two tertiary lobes.

Included species.

algens: Dimorphoceras algens Gordon, 1957, p. 55. Alaska.

brancoi: Dimorphoceras Brancoi Holzapfel, 1889, p. 38. Rhenish Mountains.

dnieperense: Dimorphoceras dnieperense Kusina in Kusina \& Poletaev 1957, p. 41. Donets Basin.

gilbertsoni: Goniatites Gilbertsoni Phillips, 1836, p. 236. Lancashire.

holzapfeli: Dimorphoceras Holzapfeli Haug, 1898, p. 109. Rhenish Mountains. [synonym of D. brancoi]

lanceolobatum: Dimorphoceras lanceolobatum n. sp.: Gourara, Algeria.

leagramense: Dimorphoceras leagramense Riley, 1996, p. 22. Lancashire.

? carina: Dimorphoceras carina Phillips 1836, p. 237. Lancashire.

\section{Dimorphoceras lanceolobatum n. sp.}

Figures 62, 63

Derivation of name. After the shape of the adventive lobe.

Holotype. Specimen MB.C.18704.1, illustrated in Figure 62.

Type locality and horizon. Sebkha de Timimoun, locality TIM-C8 (13.3 km west of Timimoun, Algeria); Upper Bollandoceras-Bollandites Assemblage.

Material. Four phragmocones, all with a conch diameter of approximately $10 \mathrm{~mm}$.

Diagnosis. Dimorphoceras with a thinly discoidal conch and narrowly rounded venter at $10 \mathrm{~mm} \mathrm{dm}$; aperture very high. Suture line with moderately high median saddle, subacute primary and secondary prongs of the external lobe, rounded and symmetric ventrolateral saddle, and deep symmetric adventive lobe with lanceolate shape.

Table 73. Conch ontogeny (Figs 63A, B, E, F) of Dimorphoceras lanceolobatum n. sp.

\begin{tabular}{llll}
\hline $\mathrm{dm}$ & conch shape & whorl cross section shape & aperture \\
\hline $2 \mathrm{~mm}$ & thinly pachyconic; involute & weakly depressed; very strongly embracing & moderate \\
& $($ ww/dm $=0.65-0.70 ;$ uw/dm $=0.10-0.12)$ & $($ ww/wh $=1.30-1.50 ;$ IZR $=0.45-0.50)$ & $($ WER $=1.80-1.90)$ \\
$5 \mathrm{~mm}$ & thickly discoidal; involute & weakly compressed; strongly embracing & very high \\
& $($ ww $/ \mathrm{dm}=0.50-0.55 ;$ uw $/ \mathrm{dm}=0.05-0.10)$ & $($ ww/wh $=0.90-1.00 ;$ IZR $=0.40-0.45)$ & $($ WER $=2.25-2.35)$ \\
$10 \mathrm{~mm}$ & thinly discoidal; involute & weakly compressed; strongly embracing & very high \\
& $($ ww/dm $=0.40-0.48 ;$ uw/dm $=0.00-0.05)$ & $($ ww/wh $=0.70-0.75 ;$ IZR $=0.40-0.45)$ & $($ WER $=2.40-2.50)$ \\
\hline
\end{tabular}

Table 74. Conch dimensions (in $\mathrm{mm}$ ) and proportions for reference specimens of Dimorphoceras lanceolobatum n. sp.

\begin{tabular}{llllllllllll}
\hline & $\mathrm{dm}$ & ww & wh & uw & ah & ww/dm & ww/wh & uw/dm & WER & IZR & \\
\hline holotype MB.C.18704.1 & 9.5 & 3.8 & 5.6 & 0.4 & 3.4 & 0.40 & 0.69 & 0.04 & 2.41 & 0.39 & \\
\hline
\end{tabular}

Table 75. Suture line proportions (Figs 63C, D) for Dimorphoceras lanceolobatum n. sp.

\begin{tabular}{lrllllll}
\hline specimen & \multicolumn{1}{l}{ at dm } & EL w/d & EL/VLS & EL/AL & MS h & VLS w/h & remarks \\
\hline paratype MB.C.18704.2 & $9.1 \mathrm{~mm}$ & 1.74 & 2.94 & 3.47 & 0.53 & 0.59 \\
holotype MB.C.18704.1 & c. $8.5 \mathrm{~mm}$ & 1.53 & 2.97 & 3.49 & 0.52 & 0.51 \\
\hline
\end{tabular}

Discussion. The new species differs in its stouter conch and the lanceolate and acute adventive lobe from the British species D. leagramense Riley, 1996, which may occur in a similar stratigraphic position. Other species with a rounded adventive lobe are D. gilbertsoni (Phillips, 1836) and D. algens Gordon, 1957; they are thus clearly separated from D. lanceolobatum. D. brancoi Holzapfel, 1889 has an acute adventive lobe, but this is strikingly asymmetric in contrast to the lanceolate adventive lobe in the new species.

The two species D. kathleenae Moore, 1936 and D. leitrimense Moore, 1958 are from stratigraphically much younger horizons (Brigantian); both differ from the new species in the incipient subdivision of the ventral prong of the subdivided external lobe. 

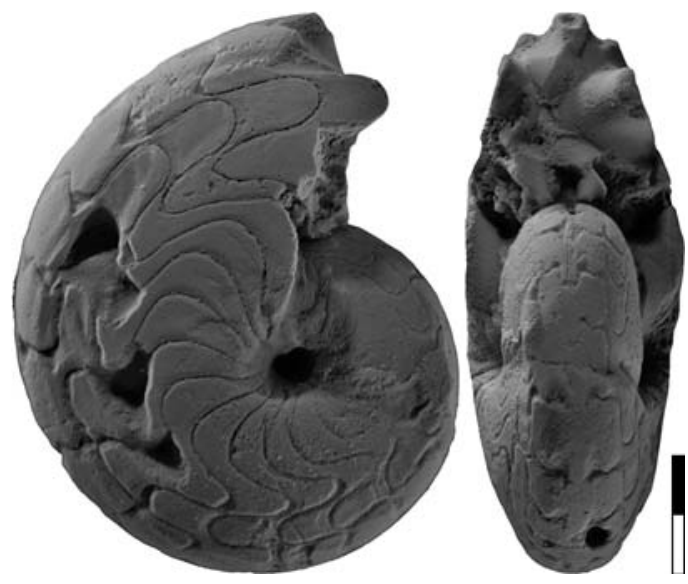

Figure 62. Dimorphoceras lanceolobatum n. sp. from locality TIM-C8. - Holotype MB.C.18704.1; ×6.0.
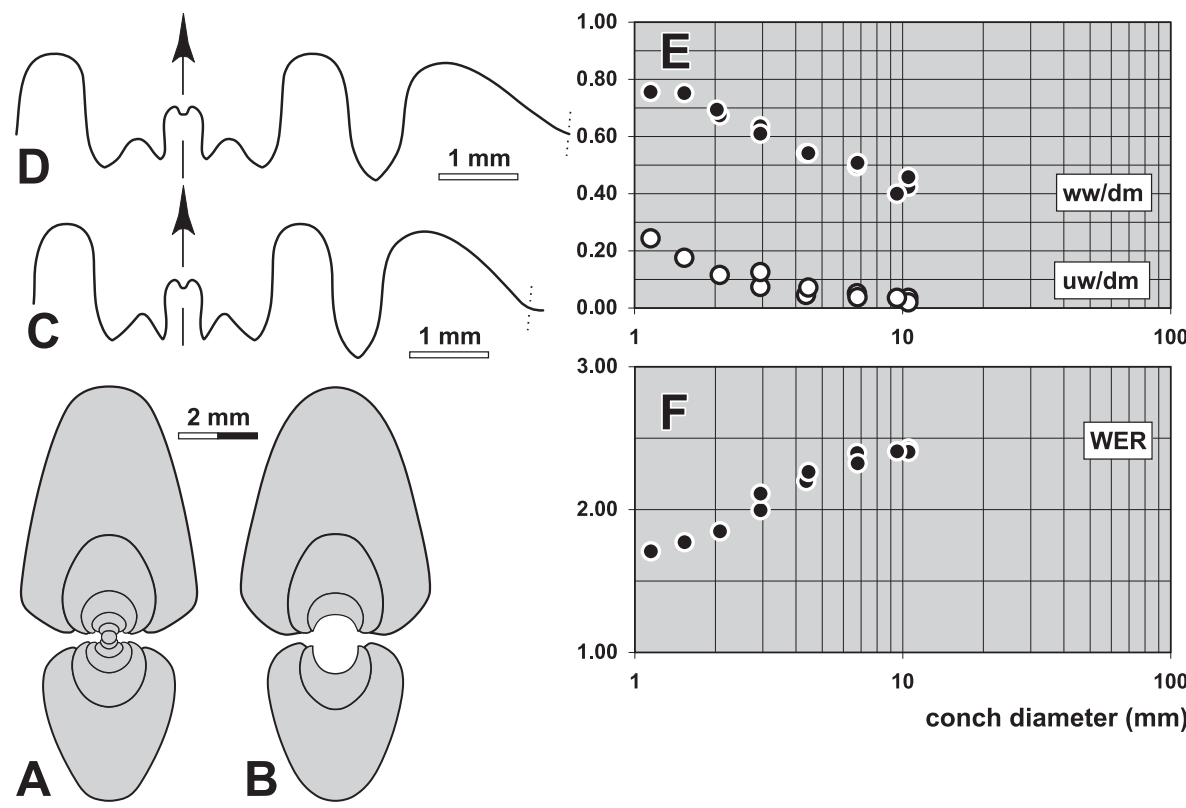

Figure 63. Dimorphoceras lanceolobatum n. sp. from locality TIM-C8. A. Cross section of paratype MB.C.18704.2; ×4.0. B. Cross section of paratype MB.C.18704.3; × 4.0. C. Suture line of paratype MB.C.18706.5,

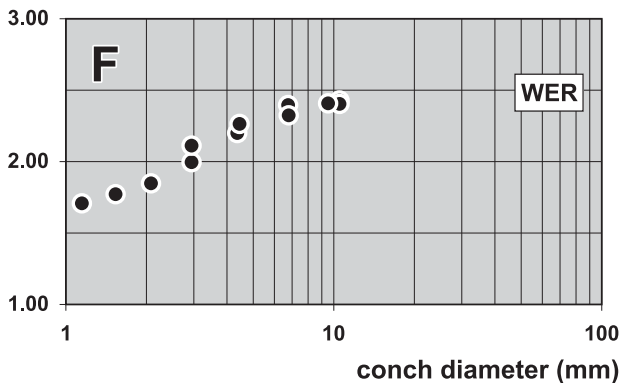
at $4.0 \mathrm{~mm} \mathrm{dm}, 2.0 \mathrm{~mm} \mathrm{ww}$; $\times 10.0$. D. Suture line of holotype MB.C.18704.1, at $9.1 \mathrm{~mm}$ $\mathrm{dm}, \quad 2.6 \mathrm{~mm}$ ww, $2.2 \mathrm{~mm} \mathrm{wh}$ $\times 10.0$. E, F. Ontogenetic development of the conch width index $(w w / d m)$, umbilical width index $(\mathrm{uw} / \mathrm{dm})$, and whorl expansion rate (WER) of all available specimens.

Superfamily Nomismocerataceae Librovitch, 1957

Family Nomismoceratidae Librovitch, 1957

Included genera.

Pseudonomismoceras Frech, 1899.

Eonomismoceras Kusina, 1974.

Nomismoceras Hyatt, 1884.

Cavilentia Ruzhencev \& Bogoslovskaya, 1971.

Applanoceras Yang, 1986 [synonym of Cavilentia Ruzhencev \& Bogoslovskaya, 1971].

Beleutoceras Ruzhencev \& Bogoslovskaya, 1971.

Simmonoceras Kusina, 1974.

\section{Nomismoceras Hyatt, 1884}

Type species. Goniatites vittiger Phillips, 1836 (subsequent designation by Foord \& Crick 1897).

Genus definition. Genus of the family Nomismoceratidae with extremely discoidal, evolute conch; whorl cross section laterally compressed with flattened flanks, usually with a ventrolateral groove; growth lines strongly biconvex.

Included species.

frechi: Nomismoceras Frechi Schmidt, 1925, p. 556; Lower Silesia.

germanicum: Nomismoceras germanicum Schmidt, 1925, p. 557; Rhenish Mountains. [synonym of N. vittiger]

marshallense: Nomismoceras marshallense Gordon, 1965, p. 248; Arkansas.

paprothae: Fayettevillea paprothae Kullmann in Horn, Kullmann \& Oliveira, 1989, p. 489; South Portugal. [synonym of N. vittiger]

rotiforme: Goniatites rotiformis Phillips, 1836, p. 237; Yorkshire. 
salim: Nomismoceras salim n. sp.; Gourara, Algeria.

spirorbis: Goniatites spirorbis Phillips, 1836, p. 237; Yorkshire. [synonym of N. vittiger]

vittiger: Goniatites vittiger Phillips, 1836, p. 237; Yorkshire.

waltoni: Nomismoceras waltoni $\mathrm{n}$. sp.; Gourara, Algeria.

? infracostatum: Nomismoceras infracostatum Schindewolf, 1951, p. 94; Harz.

? kiliani: Nomismoceras Kiliani Fromaget, 1931, p. 660; Laos.

\section{Nomismoceras salim n. sp.}

Figures 64, 65

Derivation of name. From the Arabic al-salim $=$ the faultless.

Holotype. Specimen MB.C.18705.1, illustrated in Figure 64A.

Type locality and horizon. Sebkha de Timimoun, locality TIM-C8 (13.3 km west of Timimoun, Algeria); Upper Bollandoceras-Bollandites Assemblage.

Material. 25 specimens, conch diameter between 7 and $16 \mathrm{~mm}$.

Diagnosis. Nomismoceras with thickly discoidal and evolute conch in early juveniles, rapidly becoming extremely discoidal and evolute at $12-$ $15 \mathrm{~mm} \mathrm{dm}$; aperture low, whorl expansion rate slowly increasing from 1.50 in early juveniles to $1.60-1.80$ at $12-15 \mathrm{~mm}$ dm. Adult stage with flattened flanks, ventrolateral groove and narrowly rounded venter. Steinkern without constrictions.

Table 76. Conch ontogeny (Figs 65A, B, D, E) of Nomismoceras salim n. sp.

\begin{tabular}{|c|c|c|c|}
\hline $\mathrm{dm}$ & conch shape & whorl cross section shape & aperture \\
\hline $2 \mathrm{~mm}$ & $\begin{array}{l}\text { thickly discoidal; evolute } \\
(\mathrm{ww} / \mathrm{dm}=0.48-0.55 ; \mathrm{uw} / \mathrm{dm}=0.55-0.60)\end{array}$ & $\begin{array}{l}\text { strongly depressed; moderately embracing } \\
(\mathrm{ww} / \mathrm{wh}=2.00-2.20 ; \mathrm{IZR}=0.20-0.25)\end{array}$ & $\begin{array}{l}\text { low } \\
(\text { WER }=1.50-1.55)\end{array}$ \\
\hline $8 \mathrm{~mm}$ & $\begin{array}{l}\text { extremely discoidal; evolute } \\
(\mathrm{ww} / \mathrm{dm}=0.25-0.30 ; \mathrm{uw} / \mathrm{dm}=0.45-0.55)\end{array}$ & $\begin{array}{l}\text { weakly compressed; moderately embracing } \\
(\mathrm{ww} / \mathrm{wh}=0.80-1.00 ; \mathrm{IZR}=0.20-0.25)\end{array}$ & $\begin{array}{l}\text { low } \\
(\text { WER }=1.60-1.70)\end{array}$ \\
\hline $15 \mathrm{~mm}$ & $\begin{array}{l}\text { extremely discoidal; evolute } \\
(\mathrm{ww} / \mathrm{dm}=0.15-0.20 ; \mathrm{uw} / \mathrm{dm}=0.48-0.55)\end{array}$ & $\begin{array}{l}\text { weakly compressed; moderately embracing } \\
(\mathrm{ww} / \mathrm{wh}=0.50-0.60 ; \mathrm{IZR}=0.15-0.22)\end{array}$ & $\begin{array}{l}\text { low to moderate } \\
\text { (WER }=1.70-1.80)\end{array}$ \\
\hline
\end{tabular}

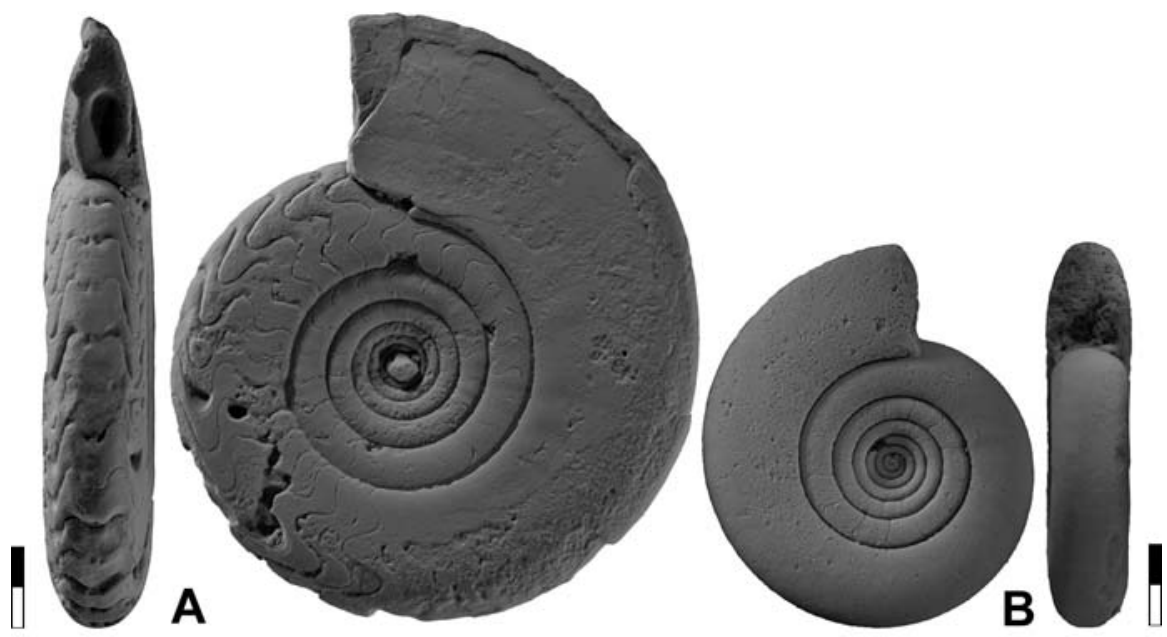

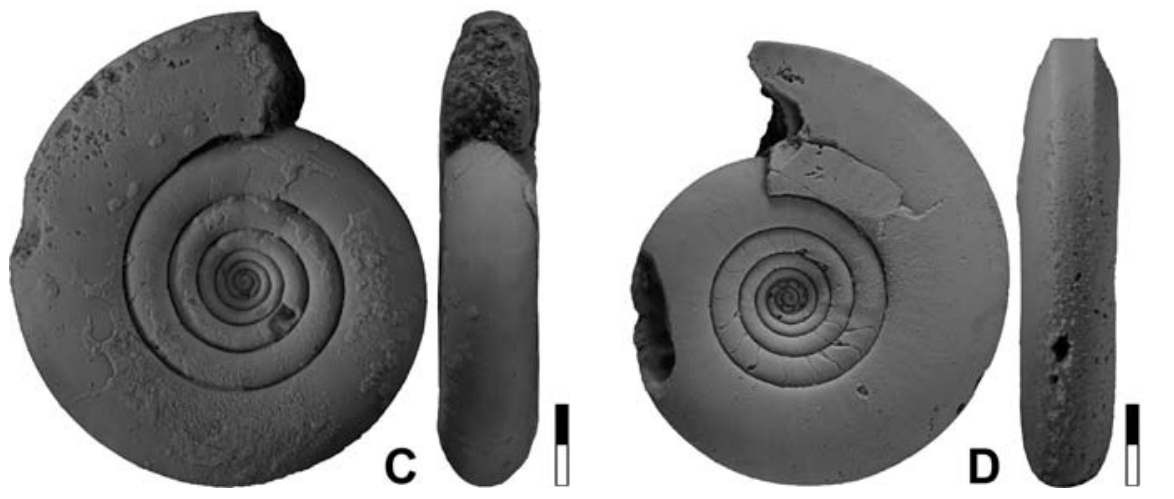

(C) 2010 WILEY-VCH Verlag GmbH \& Co. KGaA, Weinheim
Figure 64. Nomismoceras salim n. sp. from locality TIM-C8; all $\times$ 4.0. A. Holotype MB.C.18705.1 B. Paratype MB.C.18705.2. C. Paratype MB.C.18705.3. D. Paratype MB.C.18705.4. 

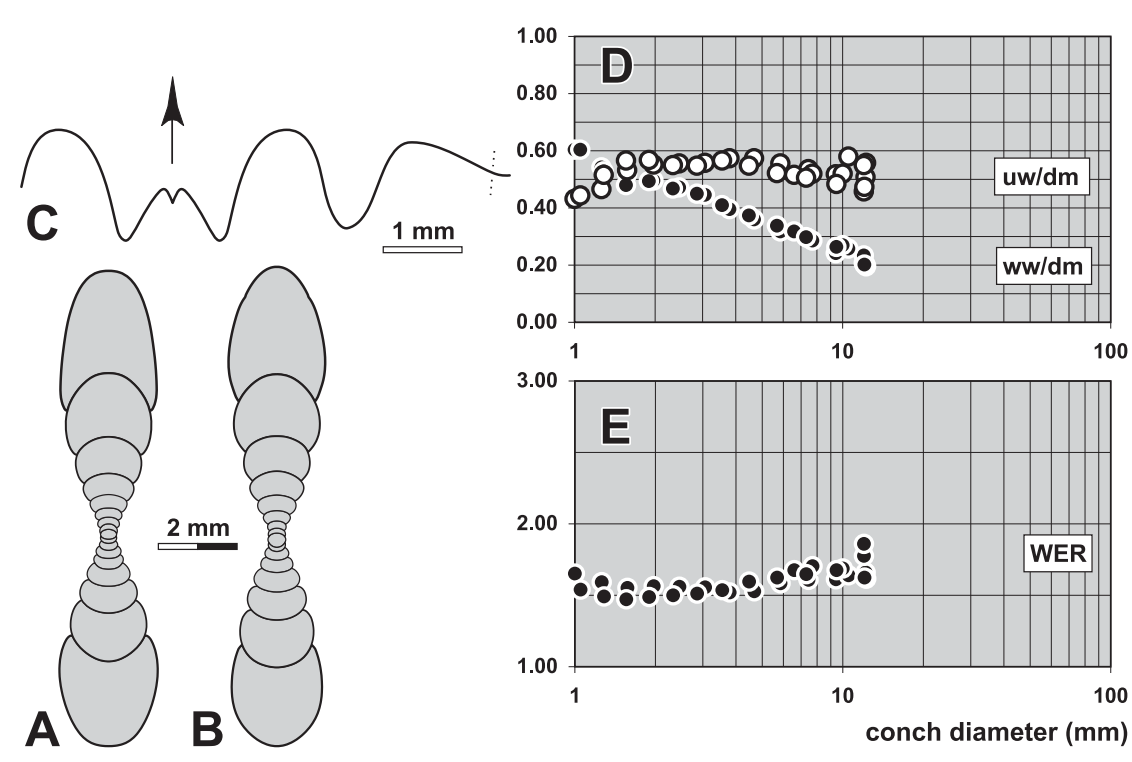

Figure 65. Nomismoceras salim n. sp. from locality TIM-C 8 . A. Cross section of paratype MB.C.18705.5; $\times 4.0$. B. Cross section of paratype MB.C.18705.6; $\times 4.0$. C. Suture line of paratype MB.C.18705.6, at $2.4 \mathrm{~mm}$ ww, $3.3 \mathrm{~mm}$ wh; $\times 8.0$. D, E. Ontogenetic development of the conch width index $(\mathrm{ww} / \mathrm{dm})$, umbilical width index (uw/dm), and whorl expansion rate (WER) of all available specimens.

Table 77. Conch dimensions (in $\mathrm{mm}$ ) and proportions for reference specimens of Nomismoceras salim $\mathrm{n}$. $\mathrm{sp}$.

\begin{tabular}{lrrrrrrrrrr}
\hline & dm & ww & wh & uw & ah & ww/dm & ww/wh & uw/dm & WER & IZR \\
\hline holotype MB.C.18705.1 & 15.9 & 2.6 & 4.6 & 7.7 & 3.7 & 0.16 & 0.56 & 0.49 & 1.71 & 0.19 \\
paratype MB.C.18705.3 & 12.5 & 2.5 & 3.3 & 6.6 & 2.5 & 0.20 & 0.74 & 0.53 & 1.55 & 0.25 \\
paratype MB.C.18705.4 & 11.5 & 2.5 & 3.5 & 5.4 & 2.9 & 0.22 & 0.70 & 0.47 & 1.78 & 0.18 \\
paratype MB.C.18705.2 & 9.8 & 2.1 & 2.9 & 4.9 & 2.4 & 0.21 & 0.72 & 0.49 & 1.73 & 0.19 \\
\hline
\end{tabular}

Table 78. Suture line proportions (Fig. 65C) for Nomismoceras salim n. sp.

\begin{tabular}{llllllll}
\hline specimen & at $d m$ & EL w/d & EL/VLS & EL/AL & MS h & VLS w/h & remarks \\
\hline paratype MB.C.18705.6 & c. $10.0 \mathrm{~mm}$ & 1.20 & 1.56 & 2.38 & 0.47 & 0.77 & A lobe subacute \\
\hline
\end{tabular}

Discussion. Nomismoceras vittiger (Phillips, 1836) closely resembles the new species, but differs in the more compressed conch shape in comparable growth stages. At $4 \mathrm{~mm}$ conch diameter, for instance, the ww/dm ratio is 0.40 in $N$ salim but 0.32 in $N$. vittiger. Additionally the umbilicus is wider in $N$. salim (uw/dm $=0.50$ at $15 \mathrm{~mm} \mathrm{dm}$ ) than in $N$. vittiger (uw/dm $=0.45$ ). N. rotiforme (Phillips, 1836) differs in the shallow ribs on the flanks.

\section{Nomismoceras waltoni $\mathrm{n} . \mathbf{s p}$.}

Figures 66, 67

Derivation of name. After Sonny Walton (Potsdam), for his assistance in preparing the manuscript.

Holotype. Specimen MB.C.18706.1, illustrated in Figure 66A.

Type locality and horizon. Sebkha de Timimoun, locality TIM-C8 (13.3 km west of Timimoun, Algeria); Upper Bollandoceras-Bollandites Assemblage.

Material. 19 specimens, conch diameter between 8 and $15 \mathrm{~mm}$.

Diagnosis. Nomismoceras with thinly pachyconic and evolute conch in early juveniles, rapidly becoming extremely discoidal and evolute at $12-15 \mathrm{~mm} \mathrm{dm}$; aperture low, whorl expansion rate slowly increasing from 1.50 in early juveniles to $1.60-1.70$ at $12-15 \mathrm{~mm} \mathrm{dm}$; adult stage with flattened flanks, ventrolateral groove and tabulate venter. Steinkern with constrictions, course biconvex with high ventral projection.

Discussion. The two species of Nomismoceras from the Timimoun section differ in a number of characters. The most striking of these is the deep steinkern constrictions in $N$. waltoni, whereas the steinkern in $N$. salim is practically smooth. Furthermore, the juvenile conch is wider in $N$. waltoni (ww/dm $=0.70$ at $2 \mathrm{~mm} \mathrm{dm}$ in $N$. waltoni and only 0.50 in N. salim).

$N$. vittiger (Phillips, 1836) is even more compressed, and this species possesses biconvex steinkern constrictions in the adult stage. The presence of riblets is another distinguishing character of $N$. vittiger. 
Table 79. Conch ontogeny (Figs 67A, B, E, F) of Nomismoceras waltoni n. sp.

\begin{tabular}{|c|c|c|c|}
\hline$d m$ & conch shape & whorl cross section shape & aperture \\
\hline $2 \mathrm{~mm}$ & $\begin{array}{l}\text { thinly pachyconic; evolute } \\
(\mathrm{ww} / \mathrm{dm}=0.65-0.70 ; \mathrm{uw} / \mathrm{dm}=0.48-0.53)\end{array}$ & $\begin{array}{l}\text { strongly to very strongly depressed; moderately to } \\
\text { strongly embracing } \\
\text { (ww/wh }=2.40-2.60 ; \mathrm{IZR}=0.27-0.35 \text { ) }\end{array}$ & $\begin{array}{l}\text { low } \\
(\text { WER }=1.50-1.60)\end{array}$ \\
\hline $8 \mathrm{~mm}$ & $\begin{array}{l}\text { extremely discoidal; evolute } \\
(\mathrm{w} w / \mathrm{dm}=0.30-0.35 ; \mathrm{uw} / \mathrm{dm}=0.53-0.58)\end{array}$ & $\begin{array}{l}\text { weakly depressed; moderately embracing } \\
(\mathrm{ww} / \mathrm{wh}=1.15-1.30 ; \mathrm{IZR}=0.15-0.20)\end{array}$ & $\begin{array}{l}\text { low } \\
(\text { WER }=1.50-1.55)\end{array}$ \\
\hline 15 mm & $\begin{array}{l}\text { extremely discoidal; evolute } \\
(\mathrm{ww} / \mathrm{dm}=0.18-0.20 ; \mathrm{uw} / \mathrm{dm}=0.50-0.55)\end{array}$ & $\begin{array}{l}\text { weakly compressed; moderately embracing } \\
(\mathrm{ww} / \mathrm{wh}=0.65-0.75 ; \mathrm{IZR}=0.15-0.22)\end{array}$ & $\begin{array}{l}\text { low } \\
(\mathrm{WER}=1.50-1.55)\end{array}$ \\
\hline
\end{tabular}

Table 80. Conch dimensions (in $\mathrm{mm}$ ) and proportions for reference specimens of Nomismoceras waltoni $\mathrm{n}$. sp.

\begin{tabular}{lrlllllllll}
\hline & dm & ww & wh & uw & ah & ww/dm & ww/wh & uw/dm & WER & IZR \\
\hline paratype MB.C.18706.7 & 12.5 & 2.4 & 3.2 & 7.0 & 2.5 & 0.19 & 0.77 & 0.56 & 1.56 & 0.21 \\
paratype MB.C.18706.6 & 11.5 & 2.5 & 2.8 & 6.6 & 2.4 & 0.21 & 0.87 & 0.57 & 1.59 & 0.16 \\
holotype MB.C.18706.1 & 10.4 & 2.5 & 2.7 & 5.5 & 2.0 & 0.24 & 0.93 & 0.53 & 1.54 & 0.24 \\
paratype MB.C.18706.2 & 9.3 & 2.6 & 2.3 & 5.2 & 1.9 & 0.28 & 1.12 & 0.55 & 1.59 & 0.18 \\
\hline
\end{tabular}

Table 81. Suture line proportions (Figs 67C, D) for Nomismoceras waltoni n. sp.

\begin{tabular}{llllllll}
\hline specimen & at dm & EL w/d & EL/VLS & EL/AL & MS h & VLS w/h & remarks \\
\hline paratype MB.C.18706.2 & $9.1 \mathrm{~mm}$ & 0.91 & 1.35 & 1.60 & 0.37 & 0.67 & A lobe very shallow \\
holotype MB.C.18706.5 & $4.0 \mathrm{~mm}$ & 0.61 & 1.04 & 1.02 & 0.19 & 0.59 & \\
\hline
\end{tabular}

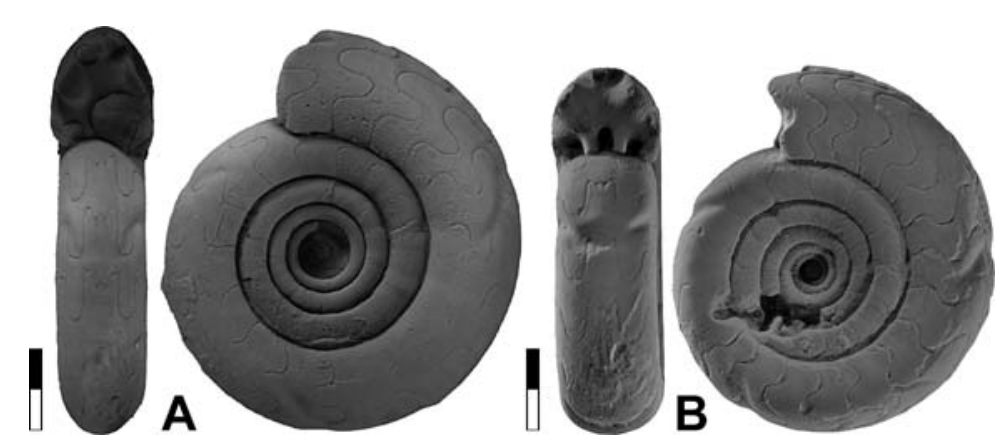

Figure 66. Nomismoceras waltoni n. sp. from locality TIM-C8; all $\times 4.0$. A. Holotype MB.C.18706.1. B. Paratype MB.C.18706.2.

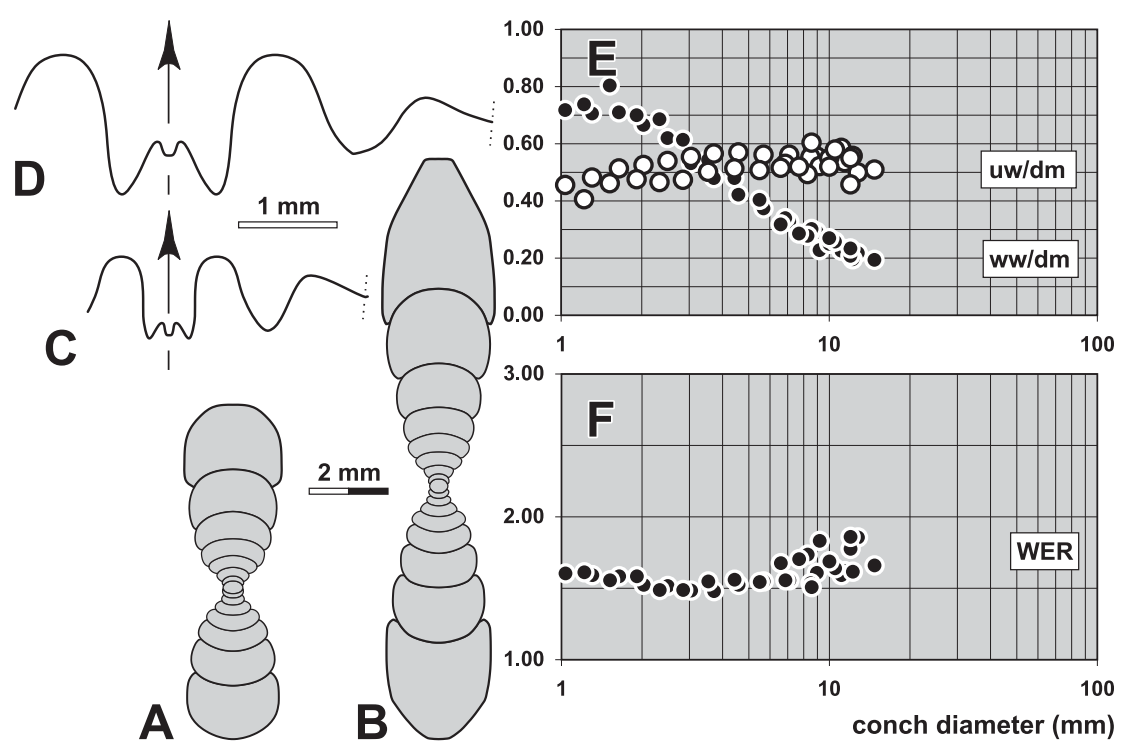

Figure 67. Nomismoceras waltoni n. sp. from locality TIM-C8. A. Cross section of paratype MB.C.18706.3; $\times 4.0$. B. Cross section of paratype MB.C. $18706.4 ; \times 4.0$. C. Suture line of paratype MB.C.18706.5, at $4.0 \mathrm{~mm}$ $\mathrm{dm}, 2.0 \mathrm{~mm}$ ww; $\times 10.0$. D. Suture line of holotype MB.C.18706.2, at $9.1 \mathrm{~mm}$ $\mathrm{dm}, 2.6 \mathrm{~mm}$ ww, $2.2 \mathrm{~mm}$ wh; $\times 10.0$. E, F. Ontogenetic development of the conch width index (ww/dm), umbilical width index (uw/dm), and whorl expansion rate (WER) of all available specimens. 
Order Prolecanitida Miller \& Furnish, 1954

Suborder Prolecanitina Miller \& Furnish, 1954

Superfamily Prolecanitaceae Hyatt, 1884

Family Prolecanitidae Hyatt, 1884

Subfamily Prolecanitinae Hyatt, 1884

\section{Michiganites Ruzhencev, 1962}

Type species. Goniatites marshallensis Winchell, 1862 (OD).

\section{Michiganites sp.}

Figure 68

Material. One fragment of the phragmocone (MB.C.18707) with a whorl height of approximately 4 mm. It shows the suture line typical for the genus but cannot be determined in greater detail.

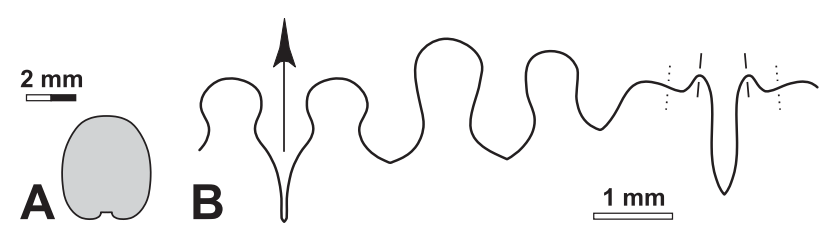

Figure 68. Michiganites sp. from locality TIM-C8. A. Cross section of specimen MB.C.18707; $\times 2.5$. B. Suture line of the same specimen, at $3.1 \mathrm{~mm} \mathrm{ww}, 3.4 \mathrm{~mm} w \mathrm{wh} \times 8.0$.

\section{Acknowledgements}

We are indebted to the regional Algerian authorities for their permission for us to undertake field work. D.K. acknowledges the Deutsche Forschungsgemeinschaft (DFG) for financial support (project Ko1829/3-1). We are grateful to Dieter Weyer (Berlin) who joined us during the first field session and contributed significantly to the collection. Technical support was provided by Wolfgang Gerber (Tübingen) for photographing most of the specimens. We also thank Sonny Walton (Potsdam) for proofreading the manuscript and Alan Titus (Kanab) as well as Dieter Weyer (Berlin) for a review of the article.

\section{References}

Bisat, W. S. 1924. The Carboniferous goniatites of the north of England and their zones. - Proceedings of the Yorkshire Geological Society 20: 40-124.

Bisat, W. S. 1934. The goniatites of the Beyrichoceras Zone in the north of England. - Proceedings of the Yorkshire Geological Society 22: 280-309.

Bisat, W. S. 1952. The goniatite succession at Cowdale Clough, Barnoldswick, Yorkshire. - Transactions of the Leeds Geologists Association 6 (4): 155-181.

Bogoslovsky, B. I., Librovitch, L. S. \& Ruzhencev, V. E. 1962. Nadotryad Ammonoidea. Ammonoidei. Sistematicheskaya chast. In Orlov, Yu. A. (ed.). Osnovy Paleontologii, Mollyuski: Golovonogie 1, 1: $243-425$.

Brown, D. A., Campbell, K. S. W. \& Roberts, J. 1964. A Viséan cephalopod fauna from New South Wales. - Palaeontology 7 (4): 682-694.

Campbell, K. S. W., Brown, D. A. \& Coleman, A. R. 1983. Ammonoids and the correlation of the lower Carboniferous rocks of eastern Australia. - Alcheringa 7 (2): 75-123.

Conrad, J. 1984. Les séries Carbonifères du Sahara Central Algérien stratigraphie, sédimentation, évolution structurale. Université de Droit, d'Economie et des Sciences d'Aix Marseille, Thèse de Doctorat d'Etat dès-Sciences naturelles. Marseille: 370 pp.

Ebbighausen, V., Korn, D. \& Bockwinkel, J. 2010. The ammonoids from the Dalle à Merocanites of Timimoun (Late TournaisianEarly Viséan; Gourara, Algeria). - Fossil Record 13 (1): 153202

Foord, A. H. \& Crick, G. C. 1897. Catalogue of the fossil Cephalopoda in the British Museum (Natural History), Part III, Containing the Bactritidae and part of the suborder Ammonoidea. London: $303 \mathrm{pp}$,

Foord, A. H. 1903. Monograph of the Carboniferous Cephalopoda of Ireland, Part V, Containing the families Glyphioceratidae (concluded) and Prolecanitidae, with title-page and index. - Palaeontographical Society 57: 147-234.

Frech, F. 1899. Lethaea geognostica, Teil 1: Lethaea palaeozoica, Band 2, Lieferung 2: Die Steinkohlenformation: 257-452.

Fromaget, J. 1931. Note sur le Daraelites des calcaires d'âge namurien de la province du Cammon (Moyen Laos). - Bulletin de la Société Géologique de France 1931: 659-661.

George, T. N. \& Ponsford, D. R. A. 1935. Mid-Avonian Goniatites from Gower. - The annals and magazine of natural history, zoology, botany and geology 1016: 354-370.

Girty, G. H. 1909. The fauna of the Caney Shale of Oklahoma. Bulletin of the United States Geological Survey 377: 1-106.

Gordon, M. Jr. 1957. Missisippian Cephalopods of Northern and Eastern Alaska. - Professional Papers of the United States Geological Survey 283: 1-61. 
Gordon, M. jr. 1965. Carboniferous Cephalopods of Arkansas. - Professional Papers of the United States Geological Survey 460: 1322 .

Haug, E. 1898: Études sur les goniatites. - Mémoires de la Société Géologique de France 18: 1-112.

Holzapfel, E. 1889. Die Cephalopoden-führenden Kalke des unteren Carbon von Erdbach-Breitscheid bei Herborn. - Palaeontologische Abhandlungen, Neue Folge 5 (1): 1-74.

Horn, K., Kullmann, J. \& Oliveira, J. T. 1989. New goniatite horizons at the Visean/Namurian boundary in Southwest Portugal. - Bulletin de la Société Belge de Géologie, de Paléontologie et d'Hydrologie 98 (3/4): 475-481.

Hyatt, A. 1883-1884. Genera of fossil cephalopods. - Proceedings of the Boston Society of Natural History 22: 253-338 (253-272 publ.1883, 273-338 publ.1884).

Hyatt, A. 1900. Tetrabranchiate Cephalopoda. In Zittel, K. v. (ed.; transl. \& ed. by C. R. Eastman). Text-book of palaeontology, volume 1, 1st edition. McMillan, New York: pp. 502-604.

Korn, D. \& Ilg, A. 2009. AMMON. Database of Palaeozoic Ammonoidea. - http://www.wahre-staerke.com/ammon/

Korn, D. \& Tilsley, J. W. 2006. Ammonoid assemblages from the Asbian B2b (Early Carboniferous: Mississippian) buildups of the Peak District, England. - Proceedings of the Yorkshire Geological Society 56 (2): 111-150.

Korn, D. 1988. Die Goniatiten des Kulmplattenkalkes (Cephalopoda, Ammonoidea; Unterkarbon; Rheinisches Schiefergebirge). - Geologie und Paläontologie in Westfalen 11: 1-293.

Korn, D. 1997. Evolution of the Goniatitaceae and Viséan-Namurian biogeography. - Acta Palaeontologica Polonica 42: 177-199.

Korn, D. 2010. A key for the description of Palaeozoic ammonoids. Fossil Record 13 (1): 5-12.

Korn, D., Belka, Z., Fröhlich, S., Rücklin, M. \& Wendt, J. 2004. The youngest African clymeniids (Ammonoidea, Late Devonian) failed survivors of the Hangenberg Event. - Lethaia 37: 307315 .

Korn, D., Bockwinkel, J. \& Ebbighausen, V. 2007. The Tournaisian and Viséan ammonoid stratigraphy in North Africa. - Neues Jahrbuch für Geologie und Paläontologie 243 (2): 127-148.

Korn, D., Ebbighausen, V. \& Bockwinkel, J. 2010a. The ammonoids from the Grès du Kahla supérieur of Timimoun (Middle-early Late Tournaisian; Gourara, Algeria). - Fossil Record 13 (1): 1334.

Korn, D., Bockwinkel, J. \& Ebbighausen, V. 2010b: The ammonoids from the Argiles de Teguentour of Oued Temertasset (early Late Tournaisian; Mouydir, Algeria). - Fossil Record 13 (1): 35-152.

Korn, D., Ebbighausen, V. \& Bockwinkel, J. 2010c. Ammonoids from the Dalle des Iridet of the Mouydir and Ahnet (Central Sahara) and the Formation d'Hassi Sguilma of the Saoura Valley (Late Tournaisian-Early Viséan; Algeria). - Fossil Record 13 (1): 203214.

Korn, D., Ebbighausen, V., Bockwinkel, J. \& Klug, C. 2003b. The Amode sutural ontogeny in prolecanitid ammonoids. - Palaeontology 46 (6): 1123-1132.

Korn, D., Klug, C. \& Mapes, R. H. 1999. Viséan and Early Namurian Ammonoids from the Tafilalt (Eastern Anti-Atlas, Morocco). - Abhandlungen der Geologischen Bundesanstalt 54: 345375 .

Korn, D., Klug, C. \& Mapes, R. H. 2005. The Lazarus ammonoid family Goniatitidae, the tetrangularly coiled Entogonitidae, and Mississippian biogeography. - Journal of Paleontology 79 (2): 356-365.

Kusina, L. F. \& Lazarev, S. S. 1994. Novye rannekamennougol'nye ammonoidei Mongolii. - Paleontologicheskiy Zhurnal 28 (1A): $157-171$.

Kusina, L. F. \& Poletaev, V. I., 1991. Novye Vizeyskie ammonoidei Donbassa i Dneprovsko-Donetskoy Vpadiny. - Paleontologicheskiy Zhurnal 1991 (3): 35-45.
Kusina, L. F. 1973. K revizii roda Muensteroceras. - Paleontologicheskiy Zhurnal 1973 (3): 14-25.

Kusina, L. F. 1974. Saurskiy kompleks ranekamennougolnykh ammonoidey. - Paleontologicheskiy Zhurnal 1974 (4): 18-31.

Kusina, L. F. 1980. Saurskie amonoidei. - Trudy Paleontologicheskogo Instituta Akademiya Nauk SSSR 181: 1-108.

Liang Xi-luo \& Zhu Kui-yu 1988. Early Carboniferous cephalopods of Baoshan, Yunnan. - Acta Palaeontologica Sinica 27 (3): 288302 .

Librovitch, L. S. 1927. Nizhnekamennougolnye golovonogie iz rayona ozera Son-kul (Tyan Shan). - Materialy po obschey i prikladnoy geologii, Geologichesky Komitet 74: 1-55.

Librovitch, L. S. 1957. O nekotorykh novykh gruppakh goniatitov iz kamennougol'nykh otlozheniy SSSR. - Ezhegodnik Vsesoyuznogo Paleontologicheskogo Obshchestva 16: 246-272.

Massa, D., Termier, G. \& Termier, H. 1974. Le Carbonifère de Libye occidentale. - Notes et Mémoires, Compagnie française des Pétroles 11: 139-206.

Miller, A. K. \& Furnish, W. M. 1958. Goniatites of the Burlington Limestone of Missouri. - Journal of Paleontology 32 (2): 269274.

Padget, P. 1952. A new species of Beyrichoceras from the "Yoredale beds", County Tyrone, Northern Ireland. - The annals and magazine of natural history, zoology, botany and geology, new series 12 (5): 864-868.

Pareyn, C. 1961. Les Massifs Carbonifères du Sahara Sud-Oranais. Tome II. Paléontologie stratigraphique. - Publications du Centre de Recherches Sahariennes, Série Géologie 1: 1-244.

Phillips, J. 1836. Illustrations of the geology of Yorkshire; or a description of the strata and organic remains; accompanied by a geological map, sections, and diagrams, and figures of the fossils. Part II. The Mountain Limestone District. London: $\mathrm{XX}+259 \mathrm{pp}$.

Popov, A. V. 1965. Novye vizeyskie ammonoidei Tyan-Shanya. - Paleontologicheskiy Zhurnal 1965 (2): 35-49.

Popov, A. V. 1968. Vizeyskie ammonoidei cevernogo Tyan-Shanya i ikh stratigraficheskoe zhachenie. - Trudy Geologicheskiy Instituta, Kirgizskiy Filial Akademiya Nauk SSSR: 1-116.

Popov, A. V. 1975. Ammonoidea (Ammonoidei). In Paleontologicheskii Atlas kamennougol'nykh otlozhenii Urala. Trudy Vsesoyuznyy Nauchno-Issledovatel'skiy Geologo-Razvedochnyy Neftyanoy Institut 383: 111-130.

Riley, N. J. 1990. A global review of Mid-Dinantian ammonoid biostratigraphy. - Courier Forschungsinstitut Senckenberg 130: 133143.

Riley, N. J. 1996. Mid-Dinantian ammonoids from the Craven Basin, northwest England. - Special papers in Palaeontology 53: 1-87.

Roberts, J. 1965. A Lower Carboniferous fauna from Trevallyn, New South Wales. - Palaeontology 8 (1): 54-81.

Ruzhencev, V. E. \& Bogoslovskaya, M. F. 1969. Reviziya semeystva Dimorphoceratidae. - Paleontologicheskiy Zhurnal 1969 (1): 5166.

Ruzhencev, V. E. \& Bogoslovskaya, M. F. 1971. Namyurskiy etap v evolyutsii ammonoidey. Rannenamyurskie ammonoidei. - Trudy Paleontologicheskogo Instituta Akademiya Nauk SSSR 133: 1382.

Ruzhencev, V. E. 1965. Osnovnye kompleksy ammonoidei kamennougol'nogo perioda. - Paleontologicheskiy Zhurnal 1965 (2): 3-17.

Ruzhencev, V. E. 1975. Ammonoidei i khronostratigrafiya Karbona vostochnoy Sibiri. - Paleontologicheskiy Zhurnal 1975 (2): 2845.

Schindewolf, O. H. 1951. Über ein neues Vorkommen unterkarbonischer Pericyclus-Schichten im Oberharz. - Neues Jahrbuch für Geologie und Paläontologie, Abhandlungen 93 (1): 23-116.

Schmidt, H. 1925. Die carbonischen Goniatiten Deutschlands. - Jahrbuch der Preußischen Geologischen Landesanstalt 45 (for 1924): 489-609. 
Shimansky, V. N. \& Kusina, L. F. 1977. Rannekamennougolnye golovonogie pripolyatnogo Urala. - Byulleten' Moskovskogo Obshchestva Ispytateley Prirody, Otdel Geologicheskiy 52 (6): 79-90.

Tilsley, J. W. \& Korn, D. 2009. Chadian (Tournaisian-Viséan; Carboniferous) ammonoids from the Milldale Limestone Formation of the southern Peak District, England. - Proceedings of the Yorkshire Geological Society 57 (3/4): 133-150.

Wang Xiang-dong, Sugiyama, T. \& Ueno, K. 1998. Carboniferous and Permian Stratigraphy of the Baoshan Block, West Yunnan, Southwest China. - Permophiles 32: 38-40.
Winchell, A. 1862. Notice of the rocks lying between the Carboniferous limestone of the Lower Peninsula of Michigan and the limestones of the Hamilton group; with descriptions of some cephalopods supposed to be new to science. - American Journal of Science and Arts 33: 352-366.

Yang Feng-qing 1986: Late Early Carboniferous ammonoids from Chenmazijing of Zhongning, Ningxia. - Acta Palaeontologica Sinica 25 (3): 260-271. 